




\title{
THE ENVIRONMENT OF VERTEBRATE LIFE IN THE \\ LATE PALEOZOIC IN NORTH AMERICA; A \\ PALEOGEOGRAPHIC STUDY
}

\author{
BY \\ E. C. CASE \\ Professor of Historical Geology and Paleontology in the University of Michigan
}

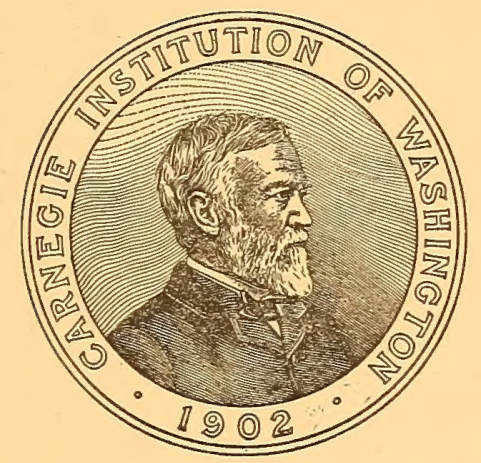

Published BY THE CARNEGIE INSTITUTION OF WASHINGTON

WASHINGTON, 1919 
CARNEGIE INSTITUTION OF WASHINGTON

Publication No. 283 


\section{CONTENTS.}

INTRODUCTION

Chapter I. The Elements of a Paleogeographic Problem. . . . . . . . . . . . . . . . I

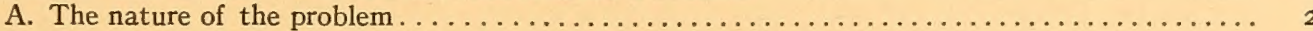

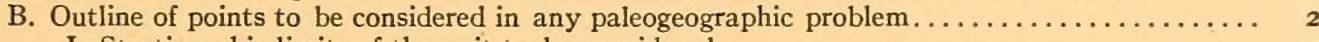

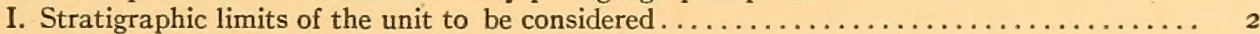

(a) Isolation of the unit by the nature of the deposits $\ldots \ldots \ldots \ldots \ldots \ldots \ldots \ldots \ldots \ldots$

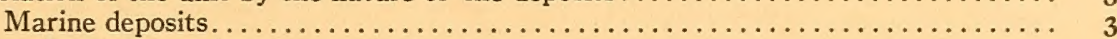

Coastal deposits . . ............................... 3

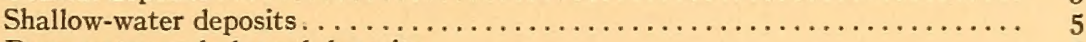

Deep-water and abyssal deposits. . . . . . . . . . . . . . . . . . . . 5

Cut-off arms of the sea . . . . . . . . . . . . . . . . . . . . . . . . . 6

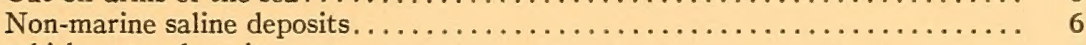

Brackish-water deposits . . . . . . . . . . . . . . . . . . . . . . . . $7 \ldots \ldots \ldots$

Fresh-water deposits. . . . . . . . . . . . . . . . . . . . . . . . .

Subaerial deposits (fluviatile, delta, and aeolian) $\ldots \ldots \ldots \ldots \ldots \ldots \ldots \ldots \ldots \ldots \ldots$

Glacial deposits. . . . . . . . . . .

Metamorphosed sediments . . . . . . . . . . . . . . . . . .

Igneous rocks . . . . . . . . . . . . . . . . . . . . . . . . . . . .

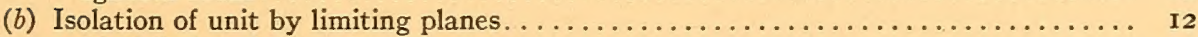

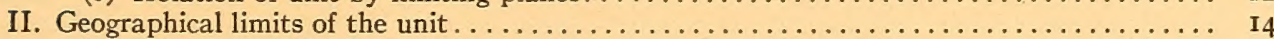

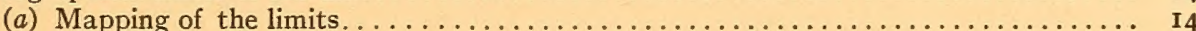

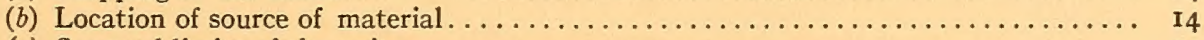

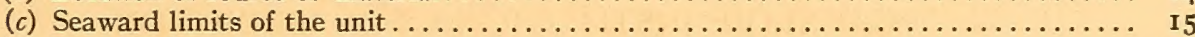

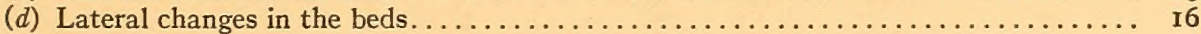

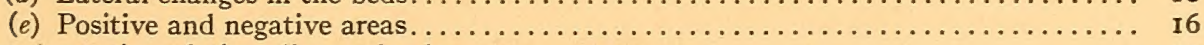

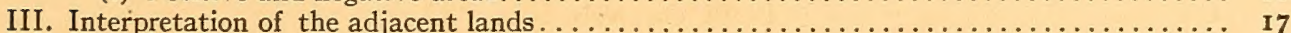

(a) Direct contact of observed surfaces of degradation $\ldots \ldots \ldots \ldots \ldots \ldots \ldots \ldots \ldots \ldots$ I7

(b) Physical character of deposits................................

(c) Mineral content. ..................................... I8

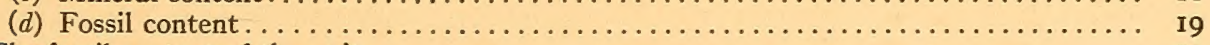

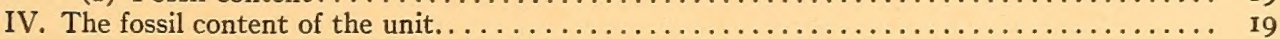

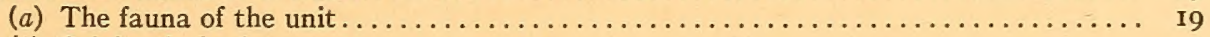

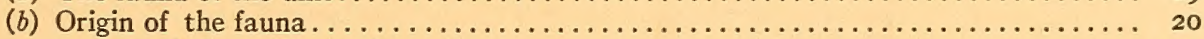

Aquatic invertebrate fauna . ............................ 20

Terrestrial invertebrate fauna . . . . . . . . . . . . . . . . . 23

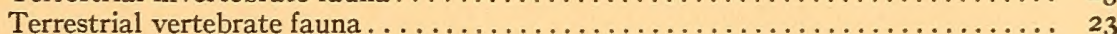

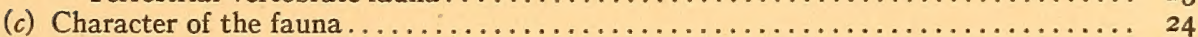

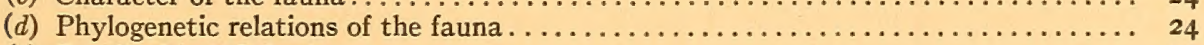

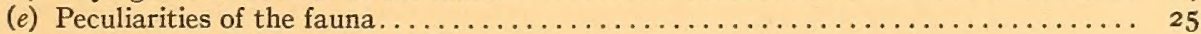

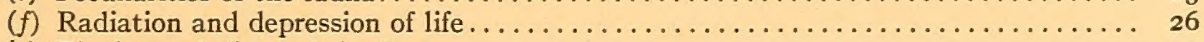

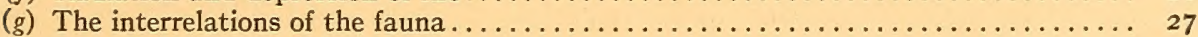

(h) Faunal elements as time markers. . . . . . . . . . . . . . . . . . . . . . . . 29

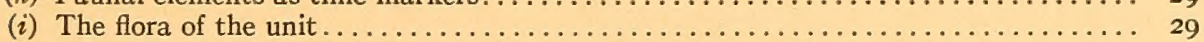

V. Correlation of unit with other beds . . . . . . . . . . . . . . . . . . . . . . .

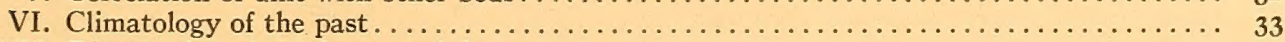

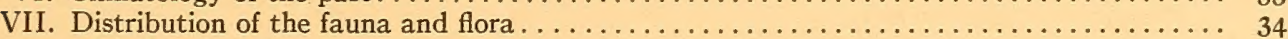

(a) Provincial or cosmopolitan . . . . . . . . . . . . . . . . . . . . . . 34

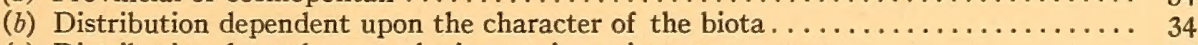

(c) Distribution dependent on the inorganic environment. . . . . . . . . . . . 35

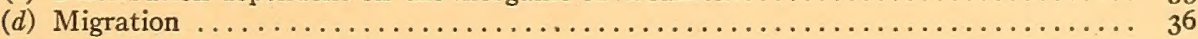

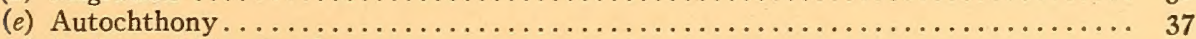

(f) Accidental introduction . . . . . . . . . . . . . . . . . . . . 37

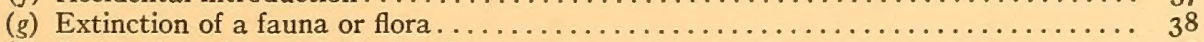

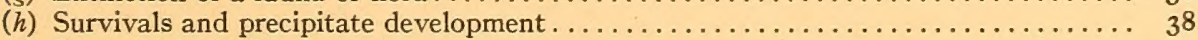

(i) Control of distribution . . . . . . . . . . . . . . . . . . . . . . . . . 39

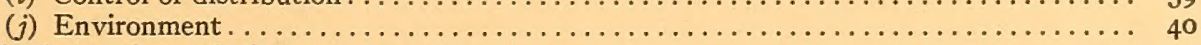

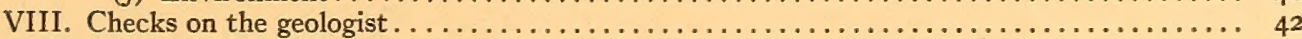

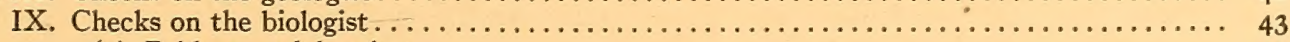

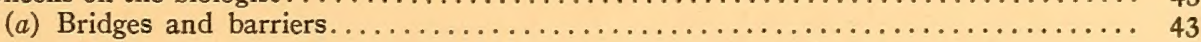


Chapter II. Summary Description of the Different Provinces of North America in Late Paleozoic Time.

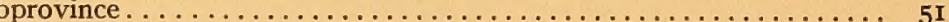

(a) The Canadian region-Prince Edward Island and New Brunswick $\ldots \ldots \ldots \ldots \ldots$ 5I

(b) The Joggins section ................................... 54

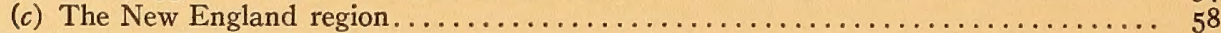

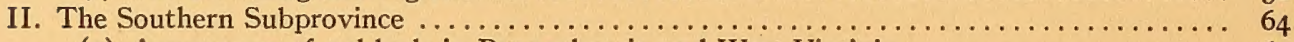

(a) Appearance of red beds in Pennsylvania and West Virginia ............... 65

(b) The western part of the Southern Subprovince....................... 76

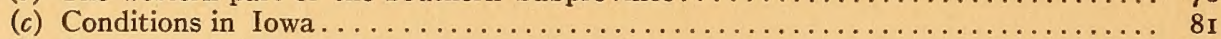

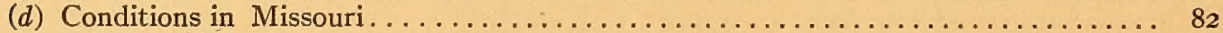

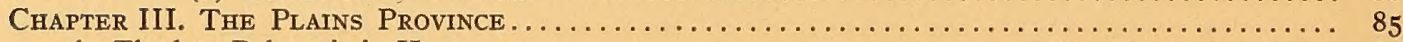

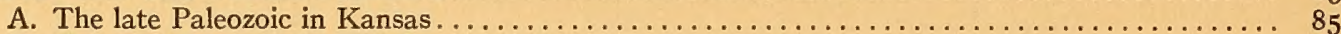

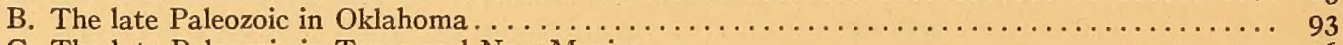

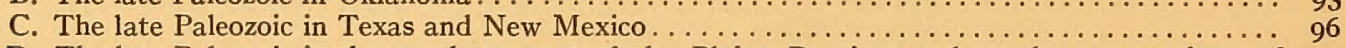

D. The late Paleozoic in the northern part of the Plains Province and on the eastern front of

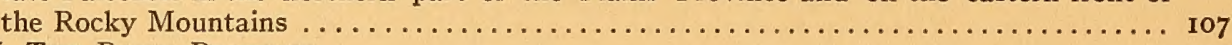

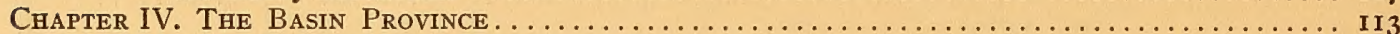

A. The upper Pennsylvanian in the Basin Province ...................... II

(a) Conditions in Texas ....................................... II5

(b) Conditions in New Mexico .............................. II

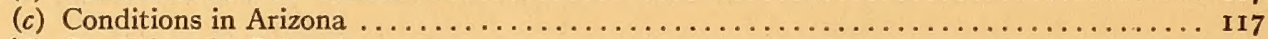

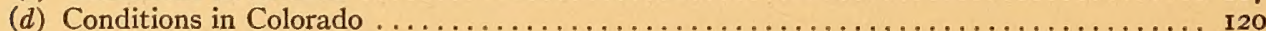

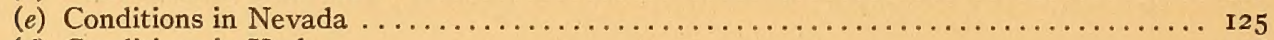

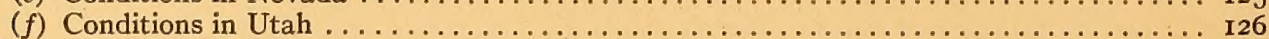

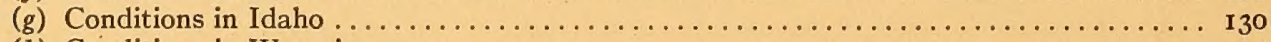

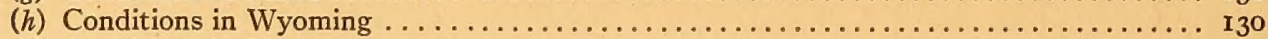

(i) Conditions in Montana ......................................... I32

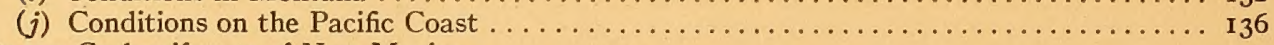

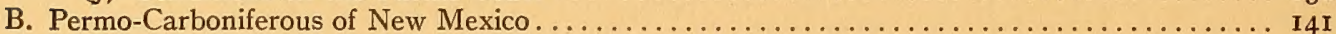

C. Permo-Carboniferous of Arizona ............................. 46

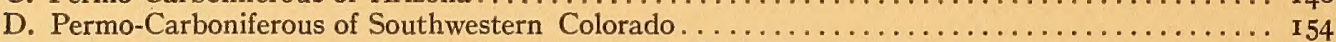

E. Permo-Carboniferous of the northern part of the Basin Province................. I59

Chapter V. The Late Paleozolc in British Columbia $\ldots \ldots \ldots \ldots \ldots \ldots \ldots \ldots \ldots \ldots \ldots \ldots$ i 7 I

Chapter Vi. The late Palegzoic in Alaska............................. I79

Chapter Vil. Interpretation of the Environmental Conditions from the Evidence of the

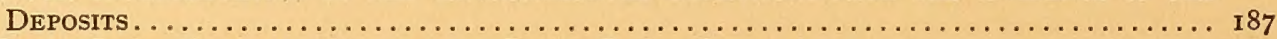

A. Permo-Carboniferous conditions versus Permo-Carboniferous time $\ldots \ldots \ldots \ldots \ldots \ldots \ldots \ldots$ I 87

B. Interpretation of conditions in Allegheny and Lower Conemaugh time............. I93

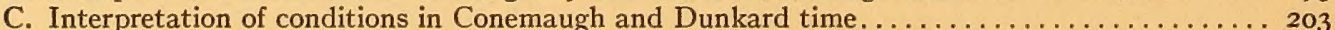

D. Interpretation of conditions in the western part of the Eastern Province........... 207

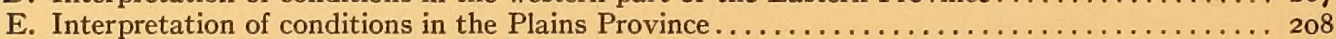

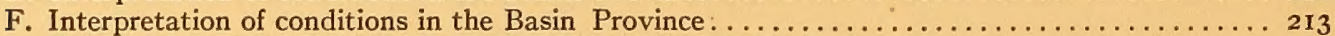

G. Interpretation of conditions in British Columbia and Alaska ................... 216

Chapter Vili. Paleobotanical Evidence as to the Equivalence of the Beds in the Eastern and the Plains Provinces. . . . . . . . . . 221

A. Evidence of fossil insects as to equivalence of the Permo-Carboniferous beds in the Eastern

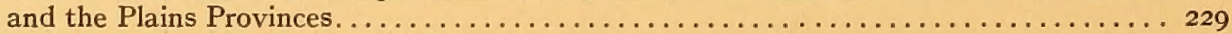

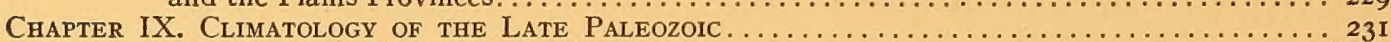

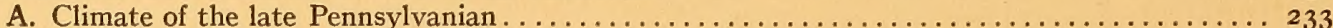

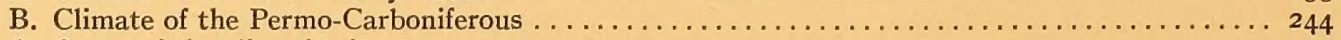

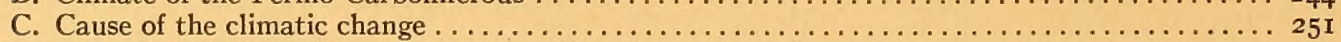

Chapter X. Areal Geography of North America in the late Paleozoic.............. 253

Chapter Xi. Development and Fate of Vertebrate life in the Permo-Carboniferous in

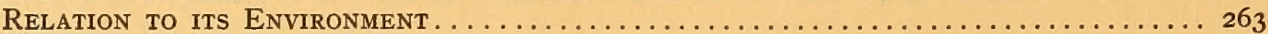




\section{INTRODUCTION.}

The author has been led to attempt this somewhat elaborate discussion of the environment of life in the latter part of Paleozoic time by many considerations. Two, however, have been dominant:

(I) He has for many years been concerned with a study of the vertebrate life of the period here discussed and has, as a preliminary to more extensive work, recorded the results of his work on the morphology and surroundings of that form of life in the publications of the Carnegie Institution of Washington and elsewhere. This work, dealing more fully. with the conditions under which certain groups had their inception, development, and decadence is a direct outcome of the previous work, and, it is hoped, the first of a series which shall embrace a discussion of this period of time wherever its records occur.

(2) As the author has carried his work to the broader questions which have developed he has become increasingly aware of the lack of agreement as to the content of paleogeography and the method of procedure in solving the various problems which arise. This publication has become, in consequence, in part an attempt to crystallize in some measure our ideas of the meaning and methods of paleogeography. The chapter upon the elements of a paleogeographic problem is an effort to set forth in orderly form the principles upon which such work should be concluded and the matter that should be treated. It is the result of the direct question which the author put to himself: What are the things that I should keep in mind when attacking a paleogeographical problem in the field? The size to which the answer speedily grew was somewhat appalling, but served as a very vivid illustration of the need for just such an analysis, primarily for the guidance of workers in the beginning of their labors. To such workers the chapter on the elements of a paleogeographic problem is especially addressed.

It is perhaps needless to state that to the author the term paleogeography involves a far more complex concept than is usually recognized by writers upon zoogeographical or paleogeographical (sic) subjects. For the discussion of the content of paleogeography the reader is referred to the chapter on the elements of a paleogeographical problem; it may be permitted to quote here a paragraph from that discussion:

"Paleogeography is the geography of past time and is far wider in its scope than a mere record of the extent of a bed or a formation, or the distribution of animals or plants in any period of time. It involves all the factors which must be considered in a modern geographical study, except the economic features appli- 
cable to human industry, and must take into account every influence, organic or inorganic, which has had any bearing upon the life of the period or formation."

Of all the definitions of geography which have been offered, the most satisfactory is that it deals with the response of life to its environment. The method of evolution is unknown, but the directive effect of environment is unquestioned; by whatever method new forms arise the environment largely determines the course they shall run and the ultimate fate of the race. It is important, then, for this work that the term "environment" and its contents be understood. To the author's mind environment may best be defined as the sum of all the contacts which any organism or group of organisms establishes with the forces and matter of its surroundings, either organic or inorganic. The results of this somewhat complex concept of environment are discussed in the first chapter of the book.

The author is well aware of the intricacy of the problem as here suggested, but he is also most keenly aware of the inadequacy of attacking such a problem from any more limited viewpoint. The efforts of the geologist unacquainted with the principles of biology, or disinclined for any reason to use them in his work, lead to imperfect and erroneous work; the converse is just as true for the biologist. If the author shall succeed in impressing the need for adequate training in both subjects and a careful consideration of the problems from both sides, by all workers on paleogeography, an important part of this work will have been accomplished.

For the rest, any success which the author may have attained in picturing the condition under which life developed during one of the critical periods of the earlier history of the earth is largely due to the support which he has received from the Carnegie Institution of Washington, and it is a pleasure to record once more his sense of obligation to that Institution and its officers.

E. C. CASE. 


\title{
THE ENVIRONMENT OF VERTEBRATE LIFE IN THE LATE PALEOZOIC IN NORTH AMERICA; A PALEOGEOGRAPHIC STUDY
}

\author{
BY \\ E. C. CASE \\ Professor of Historical Geology and Paleontology in the University of Michigan
}





\section{CHAPTER I.}

\section{THE ELEMENTS OF A PALEOGEOGRAPHIC PROBLEM.}

\section{A. THE NATURE OF THE PROBLEM.}

Adequate treatment of paleogeographic problems has been delayed by the lack of a true appreciation of their nature. Much of the literature in paleogeography is from the pens of workers primarily concerned with the distribution of land, water, and life, and commonly inadequately prepared to discuss the complex factors which make up the true geography of any time or region. Of all the numerous proposed definitions of geography, the most satisfactory regards it as a discussion of "the response of life to the conditions surrounding it."

Paleogeography is the geography of past time and far wider in its scope than a mere record of the extent of a bed or formation or the distribution of animals and plants in any period of time. It involves all the factors which must be considered in a modern geographical study, except the economic features applicable to human industry, and must take into account every influence, organic or inorganic, which has had any bearing upon the life of the period or formation. An investigator who concerns himself solely with the distribution of life is considering the effect rather than the cause and is far from viewing the problem in the broad sense in which it should be taken up.

Obviously, then, a paleogeographic problem involves not only the determination of the location and extent of any stratigraphic unit of the earth's crust and its biota, but all the factors which have in any way determined the character of the rock or the manner of its deposition and all the factors which have in any wise influenced the location, movements, and development of the fauna and flora. It is equally obvious that such a problem is enormously complex and may not be solved by attack from any one side or angle. The biologist must consider the petrographic, structural, and physiographic features of the rocks so far as they will serve to make clear the physical conditions under which life existed and developed, and the physical geologist may not neglect the laws of biology or a study of the effects of environment upon life. ${ }^{1}$

${ }^{1}$ Clements (Scope and significance of paleo-ecology, Bull. Geological Society of America, Vol. 29, pp. 369-374, I918) has recently emphasized the necessity of considering and interpreting the habitat as the causative source of developmental changes. His paper, written largely from the botanical standpoint, stresses the need for the same method of attack as is urged in this work. 
Paleogeographic studies have been made repeatedly from one side or the other and maps illustrating the results presented to the scientific world. The results have almost invariably contained some assumptions or conclusions immediately recognized as highly improbable or utterly impossible by men conversant with other phases of the problem. The biologist builds bridges of impossible position and extent to accommodate the observed distribution of plants or animals and the physical geologist describes lands or seas where the evidence of life denies the possibility of their existence or of their assumed character.

For this reason the following attempt at a concrete outline of a paleogeographic problem is presented to direct attention to the multiplicity of factors that must be considered. One half of this outline will appear obvious and unnecessary to the stratigrapher and the other half will appear equally superfluous to the biologist. It is hoped that in directing attention to both sides the errors that have formerly crept into such studies may be in some degree avoided, and especially that students now preparing themselves for such work may realize the necessity for a broader training.

The present chapter is intended simply as an outline and few points have been discussed in detail. Numerous references are given to important articles which will direct the student to the literature, to extended discussions, and to fuller information.

\section{B. OUTLINE OF POINTS TO BE CONSIDERED IN ANY PALEOGEOGRAPHIC PROBLEM.}

\section{STRATIGRAPHIC LIMITS OF THE UNIT TO BE CONSIDERED.}

The paleogeography of any geological unit becomes increasingly difficult of solution as the size of the unit is increased, whether in space or time. As the size of the unit is increased generalities must necessarily take larger and larger part in the observations and the conclusions will be proportionately looser and less capable of direct proof. In order to obtain the most definite results the limits, both geographic and stratigraphic, must be as confined and as strictly and accurately determined as possible. Such isolation of the unit demands not only a consideration of the stratigraphic and geographic limits, but of the homogeneity of the deposit in all ways, mineralogic, physical, biologic, etc., which reflect the uniformity of the conditions under which the bed was formed. Vertical, horizontal, and accidental changes are all too frequently neglected or undervalued and incongruous elements included in what should be a carefully restricted unit. Among the accidental inclusions may be listed, as a suggestion of the many possibilities, creep or slide of material from above onto an exposed surface, reworked material, residual matter included in cavities of an older formation (as the Devonian matter included in rifts of Silurian limestones near 
Chicago), ${ }^{1}$ river channels cut in an older formation, ${ }^{2}$ etc. Such accidents would bring in extrinsic material, both inorganic and organic.

(a) Isolation of the Unit by the Nature of the Deposits.

The most obvious character by which a bed may be isolated is the source of the deposits, which is generally revealed in a broad way by the nature of the materials and the included fauna or flora. Aside from the more common criteria given in the text-books the following points may be noted:

\section{MARINE DEPOSITS.}

COASTAL DEFOSITS.

These may be either conglomerates or sandstones, resulting from the action of waves in the advance or retreat of a strand-line. Advancing waves will produce different results, dependent upon the character of the land over which they make their way. If they are cutting back a high cliff of hard rock, abundant bowlders and pebbles will be formed at the foot of the cliff, to be later converted into a conglomerate, and if the cutting down of the cliff is not completed the fallen blocks may be detected and identified within the persistent mass at the foot of the former cliff, as in the sandstones surrounding the Baraboo Range in Wisconsin. ${ }^{3}$ This is a most significant occurrence, as it locates the position of the strand-line in one interval of time and determines one edge of the unit under consideration.

A conglomerate formed by a sea encroaching upon a cliff composed of strata of several geological periods would contain bowlders of different kinds of rock bearing very different faunæ. The age of such a conglomerate could only be determined by its stratigraphic position; it would not be at all likely that fossil remains of contemporaneous animals would be preserved in the conglomerate, because the shells would be triturated by the moving stones before they were cemented into the conglomerate. Even if the cliff were formed of rocks of a limited period of time, the resulting conglomerate would contain fragments from numerous zones of life, so that a careful analysis would be impossible. If such a condition is suspected the conglomerate should be traced, if possible, to its source and a careful study made of the physiographic conditions when the bowlders of the conglomerate were formed. The pebbles of a conglomerate should always be under suspicion and the fauna of the pebbles never considered as representing one formation or zone unless analysis of the source fully justifies such a conclusion. An admirable example of the mixture of faunæ must occur in

1 Weller, Stuart, Journal of Geology, vol. vII, p. 483, I899.

${ }^{2}$ Case, E. C., Carnegie Inst. Wash. Pub. No. 207, pp. 77 and 78, I9I4.

${ }^{3}$ Salisbury, R. D., and W. A. Atwood, The Geography of the Region About Devils Lake and the Dells of Wisconsin. Bull. V., Wisconsin Geological and Natural History Survey, p. 29, 1900. 
the pebbles and bowlders forming at the base of the cliffs on the Gaspe Peninsula, where an unbroken series of rocks represents several geological periods. ${ }^{1}$

In cases of marine planation, where the waves have advanced for a long distance either over reduced cliffs or across a country of originally more subdued topography, similar conglomerate would result, but the débris would probably be of smaller size, due to prolonged wave-action, and would be thoroughly mixed and spread over a far larger area, and recognizable fossils of a contemporaneous fauna would be present. ${ }^{2}$

If the waters should advance over a large area where the rocks are inclined, even at a low angle, and successive outcrops occur in parallel bands, a mixing of the rock débris and older fauna would result from the sequent erosion of the successively outcropping beds. We might expect such a basal conglomerate to have been formed by the encroaching Comanchean Sea in Texas or more strikingly as it conquered the southern part of the Arbuckle uplift. If the encroaching strand were parallel to the strike of the outcrop, the various elements would be distributed in broad bands unless disturbed by currents. If the advancing strand were at right angles or any large angle to the strike of the outcrop, the mixing of the material and older faunæ would be far more complete.

In the case of marine planation of a land of low relief, it would be expected that much of the material of the conglomerate would be fragments of loosened material which had lain long upon the surface or buried in the residual soil, and the bowlders would present a far more weathered appearance than if the waves had cut back a cliff of hard rock.

In the case of marine waters breaking in upon a land of low elevation, as the relatively rapid flooding of a peneplain or the submergence of a land below the sea-level by the failure of barriers, the advance of the strand would be so rapid that little effect would be produced upon any residual masses of hard rock and there would be no evidence of sea cliffs, shelves, etc., except at the highest level of the water, and little or no fresh material would occur in the conglomerate, but a large amount of weathered material might be expected. The loosened regolith of the invaded land would be sorted and the conglomerate would alternate with irregular beds of finer material where quieter water or greater depths permitted its accumulation. One would not be surprised to find in such deposits the remains of land plants and animals. Noble, in his account of the history of the Grand Canyon of the Colorado, cites one such instance. ${ }^{3}$

${ }^{1}$ Clark, J. M., New York State Museum Memoir No. 9, 1908.

${ }^{2}$ Folio 98, Tishomingo, U. S. Geological Survey.

${ }^{3}$ Noble, L. F., The Shinumo Quadrangle, Bull. 549, U. S. Geological Survey, pp. 42 and $80-83$, I9I 4 . 
SHALLOW-WATER DEPOSITS.

Following the conglomerate in the advance of the strand and finally covering it are the shallow-water deposits, the finer sands, sandy muds, and pure muds formed in the quieter region beyond the zone of wave-action. Such deposits may result from so many different original conditions and different forms of transportation that the utmost care is necessary in the differentiation and interpretation of the beds. The presence of marine fossils will at once determine the general character of the deposits, and this may be checked, if necessary, by the adjacent formations, both horizontally and vertically.

Regularity in the bedding with a high degree of purity in the fauna (lack of accidental inclusion of foreign forms, as terrestrial or fresh-water animals or plants) indicate accumulation in large bodies of quiet water. Specimens of land vegetation floated out, waterlogged, and sunk have been obtained by dredgings far from land and in relatively deep water; such sporadic occurrences in beds of great age are not impossible and mean no more than accidents of distribution, but they may give a hint of the proximity of powerful streams upon the land and some idea of the vegetation which covered the land at the time of their deposition.

By far the larger proportion of the sedimentary beds encountered in geological investigation are marine accumulations in shallow water, and most of the following remarks are applicable to them. ${ }^{1}$

DEEP-WATER AND ABYSSAL DEPOSITS.

These are most easily detected by the peculiarities of the deposits and fauna and the absence of shore débris. Deep waters are not, however, always remote from the shore, and the proximity of abysses even to mountain lands, as the coast of Japan, may permit the remains of shore and land life and shore débris to be swept out and deposited in unusual surroundings. ${ }^{2}$ Thus it would not be impossible that on the shores of Japan or the Pacific coast of North America the impetuous streams might carry mountain forms or mountain débris so far out that they would ultimately rest in the depths of the abyss.

It has been pointed out that the abyssal deposits of to-day are not necessarily the same in character or fauna as those of the remote past. Neither red muds nor oozes may have been formed in the depths of the

${ }^{1}$ Concerning shallow-water deposits and subaerial deposits, the student should read with close attention Barrell, Relative Geological Importance of Continental, Littoral, and Marine Deposits, Journal of Geology, vol. XIv, Nos. 4, 5, and 6, I906, and Bulletin Geological Society of America, Rhythms and the Measurement of Geological Time, pt. II, p. 776 , vol. 28 , I9I8. While much that the writer points out is not readily seen in limited exposures, the paper is full of suggestive points of view and working hypotheses.

${ }^{2}$ White, David, Value of Floral Evidence in Marine Strata as Indicative of Nearness of Shore Line, Bull. Geol. Soc. Amer., p. 22I, vol. 22, I9I I. 
Paleozoic seas, and the student of paleogeography may well pause before he declares that no abyssal deposits occur upon the continental blocks. Chamberlin has shown that the low temperature of the deep water of the recent oceans is possibly the result of recent changes, and totally different conditions may have prevailed in more normal conditions of the earth. ${ }^{1}$

CUT-OFF ARMS OF THE SEA.

Areas of water partly or completely separated from bodies of marine or brackish water, but periodically or continuously supplied with less saline water, become concentrated by evaporation until they are finally desiccated or reach the point of saturation and begin to deposit their salts. Deposits from such bodies of marine water are readily distinguished from salt lakes or playa lakes by the character of the contained fossils. In a typical development, the lower beds should contain a normal marine fauna which would gradually become pauperized, losing many of its members and having others dwarfed or developing extreme specializations.

The Gulf of Kara Bagaz, on the eastern side of the Caspian Sea, though not marine, illustrates one case in which the process is in active development. The Salina deposits of the upper Silurian in New York and adjacent States is a good example of such action in past time.

\section{NON-MARINE SALINE DEPOSITS.}

Salt lakes.-Lakes without an outlet which have endured some time, or playa lakes, subject to periodical desiccation, leave evidence of their former existence in deposits of soluble salts. Gypsum and salt are the most common, but borax, niter, and other less soluble substances, as the calcareous tufas of the dying lakes of Nevada, tell the same story. Indications of such temporary bodies of water are also seen in the presence of nonmarine fossils, which show in their structure the effects of the stress of adverse conditions. (See below, page 25.) The story of such lakes may be in part interpreted from the succession of the deposits laid down in the order of their solubilities; here the worker should turn to Clark's Data of Geochemistry for invaluable information. ${ }^{2}$ Gilbert's History of Lake Bonneville ${ }^{3}$ may be taken as a type study of such conditions and a guide for future work.

Salt swamps.-By this is not meant the great salt marshes of the seacoast, where the flux of the tides inundates and drains the land, bringing an abundant marine life and supporting the growth of a typical and luxuriant vegetation, but rather the great areas where depression of the surface permits the accumulation of waters from salt springs.

${ }^{1}$ Chamberlin, T. C., On a Possible Reversal of Deep-sea Circulation and Its Influence on Geological Climates, Journal of Geology, vol. I4, pp. 363-373, I906. Dacqué, Grundlagen u. Methoden der Paläogeographie, pp. I72 and 213.

${ }^{2}$ Clark, C. W., Data of Geochemistry, Bull. 6r6, U. S. Geological Survey, Igr6.

${ }^{3}$ Gilbert, G. K., Lake Bonneville, Monograph I, U. S. Geological Survey, 1890. 
Such deposits would be indicated by the presence of large amounts of water-soluble salts in connection with the peculiar structure of the beds. The sparse vegetation and the equally sparse animal life, both of a peculiar kind, would leave the deposits singularly barren of fossils and devoid of the excess of carbonaceous matter which would produce the black, blue, or green colors so common in normal swamp deposits. Salt swamps occur to-day in some arid regions, as in the Salt Plains of Oklahoma or in Australia, and are apt to be but phases in the life of playa lakes. The periodic desiccation is likely to produce bright red colors by the oxidation of the iron in the débris swept into the swamp by the winds and waters of violent storms. ${ }^{1}$

\section{BRACKISH-WATER DEPOSITS.}

Brackish-water deposits may accumulate in tidal estuaries and marshes, in regions subject to periodic flooding by the sea, or near the mouths of streams. Less common are brackish-water deposits in lakes approaching salinity, but the fauna of these is so distinct from that of bodies of water rendered saline by the admixture of marine waters that the distinction would not be difficult in the deposits of past geological periods.

Estuarine deposits. - These are characterized by the mixed fresh-water and marine fauna and by the rapid alternation and irregular position of the beds due to the changing composition of the water and the shifting currents as the tide meets the river. Could the whole length of the estuary be laid bare, the gradual change from fluviatile deposits and faunæ to marine deposits and faunæ would be apparent; river gravels and mud banks would give place to the mixed and irregular deposits of the region of tidal influence, and these to the regular deposits of the open sea. Where the invading tides checked the river current the deposits would be in the nature of delta deposits, but a delta would not form, because the ebb of the tide, with its resultant quick outflow of the marine water and the dammed-back river waters, would scour out the deposited sediments. However, there would be much material left on the sides of the main channel where the retarded stream and the inflowing tide would spread over the adjacent lowland. The deposits here would be delta-like and floodplain-like in character, but would differ from the subaerial portion of a delta or a flood-plain in the inclusion of marine or brackish-water fossils. Times of especially high tide or of great flood in the streams would carry the deposits and life of one region far into the domain of the other and might leave very puzzling accumulations for the paleogeographer to interpret.

The upper reaches of such a large estuary as Puget Sound in the early Tertiary would show all the conditions of a fresh-water swamp. The retarded rivers far above the reach of salt water would spread abroad and by the filling

${ }^{1}$ Gould, C. N., Geology and Water Resources of Oklahoma, Water Supply Paper No. 148, U. S. Geological Survey, 1905 . 
of the channel form stretches of swamp and morass, where abundant terrestrial vegetation would result in the formation of highly carbonaceous beds. ${ }^{1}$

Tidal marshes, lagoons, and bayous subject to occasional or periodic inundation by the sea would also present a mingling of brackish-water and marine forms of life, but the deposits would be more regularly bedded and, due to the greater intervals between periodic floodings, there would be a zonal distribution of the fossils with a recurrence of the distinctive faunæ. This theoretical arrangement might be disturbed by the action of stormwaves in shallow water and perhaps difficult to detect because of the thinness of the successive deposits. In general, however, the deposits would be more regular and more easily defined geographically than those of an estuary. Mapping should give a hint as to the nature of the deposit, as the linear form of the estuary would generally betray its character if considered with the other features.

\section{FRESH-WATER DEPOSITS.}

Lakes of large size reproduce in some degree the form of coastal and shallow-water deposits of the oceans, but the presence of fossils of freshwater life would at once distinguish the two. Due to the smaller size, lack of tides, strong currents, and powerful wave-action, there would be less perfect sorting of the material; i. e., the relatively far greater amount of terrestrial material swept in would always be a noticeable factor, and no surprise would be felt at the appearance of the remains of land animals or plants.

\section{SUBAERIAL DEPOSITS.}

Fluviatile deposits are most apt to be encountered as seemingly extraneous accumulations in homogeneous beds or, if making up the bulk of the observed beds, as irregular masses difficult to resolve into their constituent elements. When recognized and analyzed into parts, each deposit is linear in general form if enough remains for the shape to be made out, or if the conditions are favorable for such an observation. Not uncommonly river deposits are revealed in cross-section by the dissection of old plains, flats, swamps, or even marine deposits. ${ }^{2}$ In such cases the deposits were generally laid down in more or less sharp valleys formed in an uplifted and eroded marine deposit. Alluvial fans formed either upon land or in shallow bodies of water of small size also belong in this group. True deltas are considered elsewhere.

Old river-channels are generally readily recognized by the shape of the cross-section of the deposits and the arrangement of the material as a linear, narrow lens quite sharply marked off from the material on either side. In such deposits the inorganic material and fossils, other than the aquatic forms directly referable to the river itself, would be apt to resemble those

\footnotetext{
${ }^{1}$ Folios 86, I06, and 139, U. S. Geologcial Survey.

${ }^{1}$ Case, E. C., Carnegie Inst. Wash. Pub. No. 207, p. 78, 1915.
} 
occurring in the adjacent deposits. However, it is very possible and not uncommon that deposits in such channels would be made up of material carried from a considerable distance and both the inorganic and organic contents might be derived from regions remote both in space and character from the observed banks of the old stream. A stream descending from a mountain or a high plateau to a lowland might sweep down and deposit on the flat material of a totally different composition and the remains of a life belonging to zones of radically different temperatures, altitudes, and soils. It is possible that remains of animals of very different habitat might be found embedded together.

The author has in mind a locality in New Mexico where such a fossil stream-channel yielded the skull of a highly aquatic amphibian in close association with the vertebra of a land reptile, while but a few feet away in the red sandstones and clay which were once the margin of the stream remains of terrestrial and swamp animals occurred in fairly regular beds.

The presence of stream-channels, except in the rare instances of underground streams, is an evidence of subaerial erosion, and they must uniformly lie below the level of the lower plain of an unconformity. There may be a bending down of the line of unconformity at this point if the old streamvalley was a wide one or had cut deeply into the older rocks. In cases where the river deposits were slight in amount or where the interval of exposure was long with much erosion, or where marine planation had followed, all traces of the river might be removed.

Flood-plain deposits are not infrequent. ${ }^{1}$ The flooding of streams from whatever cause results in accumulations of material in wide flats which may attain considerable thickness. The fluctuation of currents in the flood waters and the very position and duration of the deposition causes the beds to be extremely irregular in arrangement and composition. Rapid variations of the strike and dip of outcrops, prevalent discontinuity of individual beds, cross-bedding, and truncation of older beds by younger, are common characters. Conglomerates, sandstones, shales, and muds alternate rapidly. Such deposits yield a pretty full record of their history upon close examination.

The physical characters of flood-plain deposits formed in arid and humid regions would be in many ways very similar, though it is probable that the violence of the floods of arid regions would leave their record in the coarser material and the evidence of stronger currents.

The chemical and physical character of the material reveal to a large extent the climatic conditions under which the beds were formed. Flat or flood-plain deposits of arid regions are marked by the presence of highly oxidized or carbonated minerals with a lack of hydrous oxides or sulphides,

${ }^{1}$ For an attempt to describe a flood-plain and subaerial delta region and reveal its history, see Case, Carnegie Inst. Wash. Pub. No. 207, I9I5. 
etc. This is largely due to the normally low water-table, which permits the penetration of the air deeply into the soil, and the exposure of the mineral constituents to oxidation or carbonation. ${ }^{1}$ Also, the lack of vegetation on an arid flat means a lack of carbon, so that there remains a larger proportion of ferric oxide, which requires the action of $\mathrm{CO}_{2}$ as an intermediate step to its solution and removal, and a lack of reduction of the other higher oxides, sulphates, and carbonates. The common result is the prevalence of a red color, ${ }^{2}$ the presence of gypsum associated with the remains of terrestrial animals, and a lack of plant remains. Wind-ripples, tracks of animals, sun-cracks, etc., are common but not always conclusive. The author well remembers his surprise upon examining a wind-rippled surface of desert sand in Arizona to find many markings which he would have unhesitatingly pronounced worm-markings upon the wave-rippled surface of a marine sandstone if the surface had been found fossil, but here the ripples were formed by the wind-were forming as we watched - and the wormlike markings were formed by burrowing insects creeping just below the surface of the heated sands, leaving trails similar to those formed by moles working their way through a light soil; nor was he able to detect a single criterion which would have caused him to reverse his decision if the surface had been an exposure of ancient sandstone.

In flats formed in humid climates the higher water-table acts by preventing a free circulation of air and inducing a heavier growth of vegetation. The excess of carbon and lack of oxygen permits the formation of the lower oxides, hydrous oxides, sulphides, and even the native metals, such as copper. The dominant colors are black, blue, green, yellow, from the presence of compounds of iron low in oxygen. Traces of plants are frequent, and such marks as footprints, rain-drop impressions, ripple-marks, etc., will be as common as upon an arid flat.

Alluvial fans and river deposits in general.-A detailed discussion of the relation of alluvial fans, terraces, and river deposits to climatic conditions in general has been given by Barrel and need not be repeated here, even in part; the student is referred to the paper as a type study of such conditions. $^{3}$

Delta deposits.-So full a discussion of the deposits has been given by Barrell that only a reference to his articles is necessary. ${ }^{4}$ Dacque has

1 A storehouse of information in regard to chemical changes will be found in Clarke, F. W., Data of Geochemistry, Bull. No. 616, U. S. Geological Survey, I916; and Van Hise, C. R., Metamorphism, Monograph 47, U. S. Geological Survey, r904.

${ }^{2}$ Tomlinson, C. W., The Origin of Red Beds, Jour. Geol., vol. 24, pp. I53 and 238, 19r6.

${ }^{3}$ Barrel, Jos., Relations Between Climate and Terrestrial Deposits, Jour. Geol., vol. Xvi, Nos. 2, 3, and 4, I908.

${ }^{4}$ Barrell, Jos., Relative Geological Importance, etc., Jour. Geol., vol. xiv, Nos. 4, 5, and 6, 1906. Criteria for the Determination of Ancient Delta Deposits, Bull. Geol. Soc. Amer., vol. 23, No.3, I912. The Upper Devonian Delta of the Appalachian Geosyncline, Amer. Jour. Sci., vol. 36, November I9I3, and vol. 37, January, March 19I4. (This last is a study of a type area.) 
drawn attention to the similarity which exists between the deposits of deltas and those of a transgressing sea. ${ }^{1}$

Aeolian deposits.-Dune sands, loess, and volcanic ash are the most common wind-carried material.

Dune sands are generally cross-bedded, but the line of the cross-bedding is more concave than where it is formed by water-currents. ${ }^{2}$ The lower part of the line is more nearly parallel to the surface below and then rises in a sharp curve; in water-laid beds the lines are straighter and at a sharper angle. Aeolian sands are generally very pure, clean, quartz grains with few or no traces of life in them. The character of the grains and the criteria for distinguishing aeolian and subaqueous sands are given by Sherzer. ${ }^{3}$

Loess is a light reddish, gritty clay, frequently splitting up in vertical columns and marked by vertical tubules due to the decay of plant roots. Not infrequently land and fresh-water shells are present. ${ }^{4}$ Such accumulations are the result of dust-storms or less violent but more persistent transportation of the fine rock débris continued over great distances and in enormous quantity. ${ }^{5}$

Volcanic ash is especially liable to be carried for great distances from its source, as it is thrown high into the air and may be caught by strong and persistent winds of high altitudes. Such drifted material frequently forms large accumulations, especially where it has fallen into bodies of water. Thick masses accumulated in the Rocky Mountain region in Tertiary times were long regarded as lake clays from their fossil content, but the microscope revealed their origin. ${ }^{6}$

Some accumulations have been found evidently formed upon land far from their source, as in Oklahoma, when the nearest source was the northeastern New Mexican volcanic region. ${ }^{7} \quad$ On the Pacific coast such accumulations carry marine fossils, showing that volcanoes, perhaps located near the margin of the continent, had contributed materially to the marine sediments.

\section{GLACIAL DEPOSITS.}

Aside from the surficial deposits of the last geological period, whose recognition is a distinct study, the traces of glaciers of the past are hardened and cemented till (tillite), scratched and soled bowlders, rounded and

${ }^{1}$ Dacqué, E., Grundlagen u. Methoden d. Paläogeographie, p. I47.

${ }^{2}$ Grabau, A., Principles of Stratigraphy, p. 701.

${ }^{3}$ Sherzer, W. H., Criteria for the Recognition of Various Types of Sand Grains, Bull. Geol. Soc. Amer., vol. 2 I, p. 625, I9I0.

${ }^{4}$ Shimek, B., Various papers, mostly in the Iowa Academy of Science.

5 Keyes, C. R., Deflation and the Relative Efficiencies of Erosional Processes under Conditions of Aridity, Bull. Geol. Soc. Amer., vol. 21, p. 565, I910. Mid-continental Eolation, idem, vol. 22, p. 687, I9II.

${ }^{6}$ Sinclair, W. J., Volcanic Ash in the Bridger Beds of Wyoming, Bull. Amer. Mus. Nat. Hist., vol. 22, p. 273 , 1906.

${ }^{7}$ Buttram, Frank, Volcanic Dust in Oklahoma, Oklahoma Geological Survey Bull. I3, I9r4. 
scratched rock surfaces, beds of conglomerate composed of angular pebbles, and the presence of large erratic blocks in marine deposits.

The typical occurrences of such evidence in rocks of Permian and Cambrian age are obvious enough, but more obscure evidence is difficult to judge. Erratic blocks may be carried trapped in the roots of drifting trees and deposited far from shore, or they may be carried by icebergs for enormous distances. Angular conglomerates may result from landslides, rock glaciers, or even sudden and violent floods originating on hillsides from cloudbursts. Their interpretation when discovered must be cautiously approached. Marks simulating glacial scratches may be produced by the slipping of masses of rocks or even by the movements of sediments previous to their cementation into rock. ${ }^{1}$

\section{METAMORPHOSED SEDIMENTS.}

These present so many difficulties in their interpretation which must be solved by severely technical methods that the problem must be in part left to the specialist in petrography, but when the original nature of the rocks is determined the history can be read upon the lines which have been suggested above. No paleogeographer should neglect the important revelations that may come from metamorphic rocks when completely and correctly interpreted.

\section{IGNEOUS ROCKS.}

Unless secondarily deposited by water or wind, igneous rocks affect the problem only in an indirect way. The alteration of any sediments by intrusion or burial by igneous rocks may aid in delimiting a unit, or the stratigraphic relations to younger or older igneous rocks may be a determining factor. Changes in color and texture due to local metamorphism can usually be easily detected.

\section{(b) Isolation of the Unit by Limiting Planes.}

A stratigraphic unit may be sharply set off from adjacent units by structural breaks, by erosional breaks, by changes in the character of the material, by changes in the bed alone; or it may pass so imperceptibly into one or other of the adjacent beds that the line of separation is indistinguishable or only distinguishable by paleontological evidence.

In the case of overthrusts, where older beds are forced above and across younger beds, the line between the two is generally very clearly marked both by the sudden change in the character of the material and contained fossils (if present) and by the disturbance of the rocks accompanying the

${ }^{1}$ Woodworth, J. B., Boulder Beds of the Caney Shales at Talahina, Oklahoma, Bull. Geol. Soc. Amer., vol. 23, p. 462, I912. 
movement. A typical case upon a large scale is the great overthrust on the eastern side of Glacier National Park. ${ }^{1}$

Erosional breaks are the most common and most looked for limiting planes, but would be apt to be present upon only one side of a unit of small stratigraphic extent. The various types of unconformity are explained and illustrated in every textbook and in typical cases are easily recognized, but increasing attention is being paid to the determination of minor unconformities and unconformities obscure because of the position of the beds. Where an exposed bed is nearly horizontal and is but little dissected by erosion, or where long erosion has reduced the exposed surface of horizontal beds to a near level surface, the succeeding deposit may be so nearly parallel and conformable as to present the appearance of uninterrupted deposition. Schuchert has described and illustrated typical instances of this condition, ${ }^{2}$ and Ulrich has repeatedly drawn attention to the necessity of determining even minor unconformities.

Erosional periods followed by the deposits of transgressing and retreating seas result in peculiarities of the unconformity which have been interpreted by Grabau. ${ }^{3}$

The true meaning of an unconformity is not always fully realized by paleogeographers, either as to the time involved, with all the possibility of structural and surface changes and changes of environment, or as to the amount of geological record lost by erosion and by lack of deposition during the period of exposure. Blackwelder ${ }^{4}$ and Barrell $^{5}$ have called attention to the importance and the significance of these erosional intervals.

Changes in bedding, in material, or in color may mean much or little, dependent upon conditions. In horizontal, persistent beds, evidently deposited under uniform conditions in quiet water, such changes would at once attract attention as indicative of some considerable disturbance either of surface or climate and hence of the life; but in delta, fluviatile, terrestrial, or even shore deposits, frequent alterations of bedding, of material, or of color are entirely consistent with unchanged conditions upon the land. Small bodies of water may easily receive material from different sources within a limited period of time; rivers may change their course or alter the velocity of their currents in a capricious manner; occasional floods may sweep together material not deposited in the same place under normal

${ }^{1}$ Campbell, M. R., The Glacier National Park-A Popular Guide to Its Geology and Scenery, Bull. 600, U. S. Geological Survey, I9I4.

2 Pirsson, L. V., and Chas. Schuchert, Text-book of Geology, pp. 586-587, I9I 5.

Schuchert, Paleogeography of North America, Bull. Geol. Soc. Amer., vol. 20, p. 44I, I9Io.

Barrel, Jos., Rhythms and the Measurement of Geological Time. Illustrations of Rhythms in Sedimentation. Bull. Geol. Soc. Amer., vol. 28, p. 798, I9I 8.

${ }^{3}$ Grabau, A., Types of Sedimentary Overlap, Bull. Geol. Soc. Amer., vol. 17, p. 567, 1907. Principles of Stratigraphy, chap. xviu.

Blackwelder, Eliot, The Valuation of Unconformities, Jour. Geol., vol. I7, p. 289, I9I4.

${ }^{5}$ Barrell, Jos., Rhythms and the Measurements of Geologic Times. Illustrations of Rhythms in Sedimentation. Bull. Geol. Soc. Amer., vol. 28, p. 798, 1918. 
conditions. Anyone familiar with the sudden appearance of an abundant vegetation in an arid region can realize how a single season of exceptional rainfall might furnish enough carbonaceous material to radically change the color of a goodly thickness of deposits. The subaerial deposits of the Permian and Triassic are notably lacking in persistence, either as to bedding, material, or color. Williston and Case have asserted their conviction that sections made at any point in these beds can not, in most cases, be depended upon a quarter of a mile away.

\section{GEOGRAPHICAL LIMITS OF THE UNIT.}

a. Mapping of the limits of the unit, preferably upon a topographic base, is a primary essential. Most commonly any exact determination of the outline is difficult or impossible because of the burial of a part of the unit under younger beds, because of the destruction of a part of the bed by erosion, or because of its interruption by structural changes. The location of hypothetical limits is always a most uncertain process and demands the utmost care and the use of every possible check, such as the physiography of the underlying beds, recognition of the horizontal changes in the material, identification of outliers, interpretation of well records, correlation with other outcrops, etc.

b. Location of the source of the material.-As suggested above, the location of the inner line of the deposit and the origin of the material is of the utmost value. If the deposits are largely or even in part clastic in character, a knowledge of the source will give much information as to the course and direction of the transporting currents, the distance covered in transportation, and the weathering or other changes that the material has undergone. At the same time, an idea may be gained of the physiography of the old land. ${ }^{1}$

In the case of a transgressing sea with progressive overlap ${ }^{2}$ of the beds, new material will be constantly gained by the waves and mingled with material carried in by rivers. The basal beds will be likely to be conglomerates, especially if the sea is advancing against a resistant coast, and this conglomerate will be a useful and easily followed criterion in determining the limits of the beds. In a regressing or stationary sea the upper beds will be finer as the waves work over the already deposited material or distribute the material carried in by rivers. Great flats would be formed as the sea retreated from its shelf and the streams poured out their waste. If, however, the retreat of the sea were rapid, caused by a sudden uplift of the land, the quickened streams might carry out much coarse sediment which, reworked by the tidal flux and by storm waves, would need careful observation of its character and content, petrographic and fossil, to distinguish it

${ }^{1}$ Barrell, Jos., Relation Between Climate and Terrestrial Deposits, Jour. Geol., vol. xvi, Nos, 2, 3, and 4, 1908.

${ }^{2}$ Grabau, Types of Sedimentary Overlap, Bull. Geol. Soc. Amer., vol. I7, p. 567, I906. 
from a basal conglomerate. Such regressive or negative movements of the sea, caused by uplifts of the land or over-deepening of the ocean basin, is generally more rapid than positive movements and a quickening of the streams frequently affords much information concerning the adjacent lands. If the land were still unsubdued, the rivers would run over hard rocks and coarse deposits would be brought to the sea, while if the land were low and covered with a mantle of residual soil the river-borne sediments would be finer and result in clay beds, or insufficient in amount to prevent the growth of organisms which in favorable localities secreted $\mathrm{CaCO}_{3}$ in large quantities, resulting in beds of limestone. In either case the change of sediments would not be conspicuous if the change from advance to retreat of the sea were actually or relatively sudden, but a change from a static strand-line to a retreat would result in a radical change of the deposits.

Such soft deposits as would follow a retreating strand under the circumstances cited above would be especially liable to destruction in any reverse movement of the strand-line; the loose material, unless cemented with exceptional rapidity, would be easily torn up and redistributed by the waves and the coarser material would be sorted out as a basal conglomerate. However, the advance of the strand over such a flat would be quite rapid and the pebbles would be little worn by the waves and would be more likely to retain the character of river pebbles than to assume that of beach pebbles.

Such unconsolidated material also would be subject to rapid subaerial erosion; the inner limits would soon disappear and the connection of the unit with the edge of the old land would be effaced and its original continuation recorded, if at all, in occasional outliers, as on the Atlantic and Gulf Coastal Plains.

If the elevation of the land were of such a character as to form mountains or steep slopes close to the most distant line of retreat of the strand, such a cycle of events as suggested above would not occur, for the material from the land would be carried out into deep water, or at least into the zone of wave action, where it would at once be distributed in the form of pure marine sediments.

c. The seaward limits of deposits.-The outer limits of any marine unit should coincide with the limits of deposition for any position of the strandline. In the open sea the approach to such an outward limit would be indicated by the occurrence of progressively finer material until the clastic débris was replaced by organic or chemical deposits. In a typical case the littoral, benthal, and abyssal zones would be marked by the fossils and the nature of the material. Such a typical series would extend over so broad an area that some portion would be almost certainly concealed by later deposits and only a very broad elevation of the land and only exceptional conditions of erosion or structural changes would expose the whole history. The determination of the outer limits of a marine deposit would be one of the 
most difficult parts of a problem to solve, especially if those limits lie in the open-sea basin rather than in a gulf or bay.

The character of sedimentation in shallow seas has recently been discussed by Barrell. ${ }^{1}$

d. Lateral changes in the character of the deposits of a marine unit, either those in sequence from the shore outward or those parallel to the strand-line, introduce most puzzling elements into the problem. Unconsciously the assumption is always made by the student, especially in his earlier experience, that a unit must be homogeneous throughout its extentalike in all its parts. The tracing of a formation by actual continuity may easily be rendered a difficult if not impossible task if the possibility of lateral changes is not kept in mind. Once the direction of the shore is determined, it is commonly assumed that each zone parallel to this will be made up of similar material and carry similar fossils in all parts. In the Paleozoic, before zones of climate were established or sharply differentiated, and when it is very possible that for a majority of the time the topography of the shores was far less diversified than now, the chances for the existence of long zones of similar deposits and fossils were far greater than in later periods, but even in that time it is to be expected that more rugged coasts gave place to wide estuaries, and that wide sandy beaches stretched along the coast at intervals; lowlands stretching back from the sea or offshore bars and reefs would have their characteristic effects, all contributing to diversify the deposits of any definite interval of time. Animal life is not conditioned by temperature alone; the physiographic conditions suggested above would cause a diversity of food-supply and habitat which would compel a diversity of life, and currents controlled by the nature of the coast would influence the distribution. Then, as now, any zone of reasonable length would have varied deposits and life in its different parts.

$e$. Positive and negative areas.-It is obvious from an inspection of paleogeographic maps that the submergences of the continents have repeatedly occurred over well-defined areas. This is clearly seen in the continent of North America. Schuchert's Paleogeographic maps ${ }^{2}$ and Ulrich's table of submergences ${ }^{3}$ bring out the plan, and it is recognized in the mapping of the positive and negative areas first suggested by Willis. ${ }^{4}$

From the Atlantic deep around the northern and southern ends of Appalachia and, rarely, across it in the vicinity of New Jersey; from the Arctic deep broadly across the Hudson Bay region, or more commonly from the northwest down the course of the Rocky Mountain prism and then

1 Barrell, Jos., Rhythms and Measurements of Geologic Time. Rhythms in Sedimentation, Bull. Geol. Soc. Amer., vol. 28, p. 776, 1918.

${ }^{2}$ Schuchert, Chas., Paleogeography of North America, Bull. Geol. Soc. Amer., vol. 20, I9Io.

${ }^{3}$ Ulrich, E. O., Revision of the Paleozoic Systems, Bull. Geol. Soc. Amer., vol. 22, pp. 346-347, I9I I.

${ }^{4}$ Willis, Bailey, A Theory of Continental Structure Applied to North America, Bull. Geol. Soc. Amer., vol. 18, p. 389, 1907. 
southeast across the Dakotas; from the Gulf of Mexico northward on either side of the Ozarkia; and finally, broadly eastward from the Pacific deep, the waters of the oceans crept over the lands, at times spreading widely, at others confined to relatively limited channels. The determination of this plan of submergences is one of the greatest steps that has been made in the preparation of a logical geological history of the continent.

\section{INTERPRETATION OF THE ADJACENT LANDS.}

The paleogeography of any unit is far from completely made out, even when the constituent rocks and fossils are thoroughly known. The composition and arrangement of the material in any bed deposited on an ocean littoral or in a smaller body of water is influenced in large measure by the nature of the land from which it was derived. The temperature of the water and the food-supply of aquatic faunæ are no less closely influenced by the condition of the bordering lands. Terrestrial deposits reflect even more closely the character of the adjacent degrading land. It is obvious that to understand the paleogeography of any unit of time it is necessary to know the condition of the land areas which have contributed the sediment to the observed stratigraphic unit. Such knowledge is gained only with great difficulty in many cases. The débris from the land which forms the observable record has in most cases undergone decided changes and must be interpreted in the light not only of all possibilities of weathering and alteration of the original material, but from the method of transportation.

a. Where direct contact can be established the land surface may in part be made out from the suggestions given above and below. Where, as in the great majority of cases, the littoral zones have been destroyed, the source of material may be recognized by the character of the sediments or inferred from possible sources of supply such as elevated regions. In such cases the nature of the contact between the eroded surface and the overlying beds may tell the extent of its degradation and the character of the surface.

$b$. The physical character of the deposits may reveal the greater or lesser degree of weathering, erosion, and transportation, and hence the ruggedness, gentleness, the velocity of the streams, the amount of protecting vegetation, climatic variations, etc. The included fossils of a land vegetation may show something of the nature of the soil and climate. Volcanic ash, loess, and wind-blown sand all help to restore the condition of the land. A typical case of the interpretation of wind-drifted sand is to be found in Grabau and Sherzer's discussion of the Sylvania sandstone of southeastern Michigan. ${ }^{1}$

Wind-blown sand, volcanic ash, and loess, however, carry far less information concerning the adjacent areas than would a water deposit. More easily carried and far more thoroughly sifted from all foreign substances, these

${ }^{1}$ Grabau, A., and W. H. Sherzer, The Monroe Formation of Southern Michigan and Adjoining Regions. Michigan Geological Survey, series I, Pub. 2, p. 6r, I9ro. 
materials tell little of the place from which they came. Dunes may form on the edge of lakes or oceans, or in the most stark desert, and in either place the information given by the structure and material of the dune would be essentially the same. The constituent sand might be gathered from barren mountain peaks, dragged from a normally well-covered region in time of drought or failing vegetation, or swept from river bars, lake or ocean beaches.

Loess and volcanic ash tell even less than aeolian sand. These are so light that they may be transported far from their place of origin and laid down in the most dissimilar places, in bodies of water, on lands covered with vegetation, or in deserts.

c. The mineral content is instructive only where conditions are most favorable. No one would be able to interpret from the deposits of a swamp in the Archezoic rocks of Canada the nature of its surroundings if the chemical content of the finer muds were alone observable. A thoroughly decomposed mass derived from various igneous rocks would give upon analysis results very similar to those obtained from many shales, but if the mineral content is still determinable by petrographic methods, or if coarser deposits on the borders of the swamp or near the inflowing streams are observable, much might be learned.

An occurrence of scattered local deposits of fine-grained shale rich in carbonaceous material or plant remains, accompanied by fresh-water fossils, and perhaps by a quantity of bog iron ore in association with pebbles of igneous rock in advanced stage of chemical decomposition would strongly suggest such conditions as now prevail in many parts of Canada. An abundance of angular fragments of similar igneous rocks with swamp deposits would suggest the former existence of such swamps as occur in the higher mountain parks, while, of course, striated pebbles would lead to the consideration of the possibility that glaciers had had some part in the formation of the swamp by interfering with established drainage.

A coal swamp in a limestone region would be even less liable to disclose the nature of the surrounding land, especially if it were of large size. The fragments of limestone carried into the swamp would disappear by solution and the infrequent stream-channels would retain such a relatively large residium of the insoluble material, as quartz sand, as to lead to erroneous conclusions, unless studied with the utmost circumspection. River deposits would be far less dependable as indices to the nature of the surrounding lands than deposits in bodies of quiet water. Large streams carry material for great distances, and the content of any fossil river-channel might be the result of accumulations from widely separated sources. The presence of igneous fragments in the middle or lower courses of the Mississippi would obviously not be a safe proof that the shores adjacent to the place where the samples were taken were formed of igneous rocks. Floating ice might 
carry such igneous fragments from far north or even farther west, if the samples were taken below the mouth of the Missouri River, or the fragments might have been gathered from the glacial drift of the banks. Certainly the content of a fossil river-channel would present no less difficulty in the interpretation of its origin. However, in such deposits the banks are usually observable and much possible error easily avoided.

d. Fossil content.-The life of marine and even fresh waters may to some extent show the nature of the adjacent land as the habits and food-supply .cause it to multiply or disappear upon shores of different character.

Reefs of Bryozoa and corals give a direct suggestion. The animals are fixed in position; the tentacles and mouths are directed upwards; any large amount of sediment falling through the water would speedily cause the extinction of most forms, though some are found living in very muddy waters. The occurrence of reef corals in large numbers in any place suggests clear water far from the mouths of great rivers or muddy currents, and opposed to coasts from which relatively little material is being washed outa land with low or wooded slopes upon which the solvent processes of degradation are more active than those of mechanical disintegration.

Other animals, as many mollusks, live near muddy coasts, or on sandy flats, etc. The student must here turn to some treatise on zoology for a discussion of the life habits of various organisms. (See also Walther, Einleitung in die Geologie, II Theil, and Grabau, A., Principles of Stratigraphy, chapter 28, Bionomic Characteristics of Plants and Animals.)

\section{THE FOSSIL CONTENT OF THE UNIT.}

(a) The Fauna of the Unit.

The fossils of animals are apt to be found in all kinds of deposits; marine beds carry by far the largest number, but terrestrial beds are frequently rich in the remains of animal life. All fossils found in water-laid beds are not aquatic forms; the remains of purely land animals find their greatest chance of preservation when swept into bodies of water, or buried in the deltas, sand-bars, mud-flats, etc., of rivers. In the case of floating carcassés, distended by the gases of decomposition or supported by floating vegetation, the remains might be swept far beyond the limits of deltas in large bodies of water and come to rest in the horizontal beds of quiet, deep water. Agassiz found remains of land vegetation on the bottom of the sea in the Antilles, I,000 fathoms down, and the Challenger dredged up plant remains from as much as $\mathrm{I}, 400$ fathoms in Polynesia. ${ }^{1}$ Animal remains might go approximately as far from the lands and sink in as deep water.

Land birds and insects are frequently blown far out to sea, only to perish and sink to the bottom or be devoured by fishes. Such accidental inclusions

\footnotetext{
${ }^{1}$ Suess, E., The Face of the Earth, English edition, vol. I I, p. 248.
} 
should not be permitted to cause an error in the interpretation of the beds. In swamp deposits and deposits of small bodies of water, either fresh or marine, the remains are apt to be those of the local fauna, terrestrial or aquatic.

The bodies of terrestrial animals which find their way into a stream may be carried long distances with the current and in times of flood may be carried far outside the normal bed of the stream and laid down on floodplains or in places where the streams spread widely over the subaerial portion of deltas. Even after the cadaver, freed from the distending gases, has sunk or been torn to pieces, the part's would be swept along until finally drawn into some eddy or stranded upon a flat. Where streams pass rapidly from one physiographic region to another this might result in the mingling of fossil forms very distinct in their natural habitat, as the remains of purely mountain or upland forms might to-day be swept out upon the surface of the Great Plains and mingled with remains of animals of radically different habitat; or animals entirely inland might be swept out by the floods of the Mississippi, Nile, Amazon, or other great rivers, and buried in subaqueous parts of the delta far from shore and intermingled with remains of marine animals. One would not regard as impossible the occurrence of the bones of the American antelope or the bison in the muds of the Mississippi delta, to take an extreme case, or the bones of horses, cows, etc., in muds of the Louisiana bayous where such remains would not naturally occur. An example of the determination of the physiographic habitat of animals is given by Osborn. ${ }^{1}$

More difficult is the interpretation of the contents of large bone-beds or shell-beds in fluviatile deposits. It would be obviously very dangerous to interpret the surroundings of such a collection from the contents of the bed until a study of the fossils permits the elimination of foreign forms. Much-worn bones or shells would naturally indicate long transportation, but when the cadavers were transported a great distance before being destroyed or the hard parts subjected to much wear this evidence of transportation would be less noticeable.

The fauna of a bed, aside from the accidental inclusions noted above, indicates the character of the deposit-marine, brackish, or fresh water, swamp, or purely terrestrial. But here a new series of factors enters the problem; the nature of the evidence shifts from the inorganic to the organic. The time element becomes as important a factor as the space element.

(b) ORIGIN OF THE FAUNA.

Aquatic invertebrate fauna.-Any fossil fauna either originated where it is found by evolution from older types, or it migrated into the region, or it

${ }^{1}$ Osborn, H. F., Cenozoic Mammal Horizons of Western North America. Bull. U. S. Geological Survey, No. 36I, Age of Mammals, pp. 84-85, I909. 
resulted from a mixture of the two processes. In the first case the group of animals was isolated for a long time and will bear evidence of its history in the presence of archaic forms and peculiar specializations such as always arise in isolated communities. Cases are rare where it can be shown that epicontinental seas existed so long undisturbed that actual evolutionary changes are apparent. Such a case perhaps is the Gaspé region in northeastern Quebec. Ulrich asserts that evolution has always taken place (in the Paleozoic invertebrates at least) in the ocean basins and not in epicontinental seas; that the faunal changes noted and attributed to evolutionary processes are due to a misapprehension of the composite nature of the beds, and that the changes are due to a retreat of the fauna to the ocean basins and its return after undergoing an evolution there. ${ }^{1}$ If epicontinental beds can be actually isolated which show the long-continued and uninterrupted presence of the sea, far-reaching conclusions as to the conditions of adjacent land and sea are usually forthcoming.

In the second case the evidence is more readily detected. The sudden appearance of a new fauna or of new types in an old fauna is almost invariably due to migration. The source of and the route of the migration become at once of interest and may be revealed in many ways.

In marine beds the appearance of new forms may perhaps be correlated with the advance of the strand as in overlaps, etc., or it may be due to rapid submergences of a land area following the breaking-down of barriers by the action, slow or rapid, of physiographic forces. It is not improbable that the sudden diversion of the Colorado River left many fresh-water forms in the layers of mud it deposited in the Salton Sink. Noble has indicated a somewhat similar action, but of marine waters, in Paleozoic time, revealed in the section of the Grand Canyon of the Colorado. ${ }^{2}$

The partial submergence of the continent of North America in Cambrian time is a similar case in point. ${ }^{3}$

The third case, where resident and migrant faunæ are mingled, is by far the most common. Classical examples of this condition occur in the various troughs of the Appalachian Basin, where new faunæ repeatedly penetrated through channels, the Quebec, Levis, etc., from the North Atlantic, and across the weak spot in the barrier of Appalachia near Chesapeake Bay, or around the southern end of Appalachia from the mid-Atlantic. ${ }^{4}$

1 Ulrich, E. O., Revision of the Paleozoic Systems. Bull. Geol. Soc. Amer., vol. 22, pp. 495-505, I9I I.

2 Noble, L. F., The Shinamo Quadrangle, Grand Canyon District, Arizona. The Hotatau Conglomerate. Bull. 549, U. S. Geological Survey, I9I4.

${ }^{3}$ Walcott, C. D., Abrupt Appearance of the Cambrian Fauna on the North American Continent. Smiths. Misc. Coll., vol. 57, No. I, pp. 1-16, 1910.

${ }^{4}$ Weller, Stuart, The Paleozoic Faunas of New Jersey, New Jersey Geological Survey, vol. 3, 1903 .

Ulrich, E. O., and Chas. Schuchert, Paleozoic Seas and Barriers, Bull. 52, N. Y. State Museum. 
Equally good examples occur in the various deposits of Devonian time, when invasions from the Arctic, across Hudsons Basin and from the northwest; or from the Gulf of Mexico, successively penetrated to the center of the continental surface. ${ }^{1}$

Here arises at once the question of the source and routes of movements of the migrant forms. The determination of the identity or distinctness of two faunæ, as the resident and the migrant, depends upon their composition and immediately introduces the question whether a fauna is to be characterized by the similarity of a majority of its species to those of another region (matching of species) or by the presence of a few unique forms. These questions have been fully discussed by competent authorities and is further considered under the subject of correlation below. ${ }^{2}$

The sudden appearance in a bed of new forms similar to the original ones, but recognizable as migrants from another region, and the absence of new types of life implies very similar conditions of water, temperature, food-supply, etc., in the old and new homes of the migrant forms and in all intervening places on the route of migration. The only disturbing factors would be those arising from competition between resident and migrant faunæ. Such an invasion could only arise when the migrations were made possible by very gentle movements between regions similar in all general conditions. It is not unlikely that similar temperature conditions prevailed widely over the earth in Paleozoic times, ${ }^{3}$ but differences in bottom, foodsupply, and so forth, could easily vary as the waters bordered on different terranes. These suggestions will be made plainer by a consideration of the faunæ of any part of the continuous seacoast of any continent to-day.

Shore-lines extending across latitude lines have very different faunæ, controlled by temperature, though other factors are also present, and ocean currents parallel to the coast may extend the range of faunæ to the north or south beyond the effect that would be produced by latitude alone. The effect of the Greenland Current and the Gulf Stream on the east coast of North America is a good example. The use of this principle in paleogeography is illustrated by Willis's paleogeographic maps, in which an attempt is made to indicate the course of currents. ${ }^{4}$

It must be recognized that the migration of invertebrates is largely accomplished by currents. The free-swimming forms would be borne by

${ }^{1}$ See Ulrich's Revision of the Paleozoic Systems and Schuchert's Paleogeography of North America, already referred to, for many instances.

${ }^{2}$ Ulrich, E. O., Revision of the Paleozoic Systems, Bull. Geol. Soc. Amer., vol. 22, p. 506, I9I I.

Williams, H. S., Bearing of Some New Paleontologic Facts on Nomenclature and Classification of Sedimentary Formations, Bull. Geol. Soc. Amer., vol. 16, p. I37, 1905.

Smith, G. P., Principles of Paleontologic Correlation, Jour. of Geol., vol. viII, p. 673, 1900.

${ }^{3}$ White, David, and F. H. Knowlton, Evidences of Paleobotany as to Geological Climate, Science, vol. 3I, p. 760, I9Io.

${ }^{4}$ Willis, Bailey, and R. H. Salisbury, Outlines of Geologic History. Maps by Willis, I9Io. 
currents and the free-swimming embryos of sedentary forms would be carried in the same way. The relatively sudden appearance of a fauna recognizable as originated in some distant region would at least lead to the consideration of the possibility of ocean currents setting from the old to the new locality and may betray the presence of a most important element in the paleogeography of the time.

Shore-lines extending parallel to lines of latitude would be more apt to have similar conditions of temperature, unless currents changed the normal conditions. The course of the Kuro Siwo brings warm water along the south side of the Aleutian Islands and warm-water forms of the western side of the Pacific are found far east.

It is obvious that temperature is but one of the influences brought to bear on a migrating fauna and great similarity of a migrant sedentary fauna to its parent fauna must imply similarity in conditions other than temperature. The known physical conditions of one region may then with some safety be applied to a second region in which the fauna is known but the physical conditions are unknown. Ideal conditions for such similarity of faunæ would be found on an east-and-west coast, such as perhaps existed on the southern shore of the North Atlantic continent.

Terrestrial invertebrate fauna.-The wide distribution of midges, ephemerids, ants, etc., overtaken in their nuptial flights by violent winds is well known. They may be blown far beyond their natural range, or caught in bodies of water in enormous numbers. The accumulation of insects in the water-laid ash-beds of Florissant, Colorado, is the record of such a catastrophe or series of catastrophes to insect life. It is very probable that regions have been reached by insects, normally absent, through such forced migrations, but it would be a faulty conclusion, if great numbers of fossils were found suddenly introduced into a horizon from which they were previously absent, that a great life migration had necessarily taken place; the bodies may have reached these as the dead débris of some violent storm. The movements of creeping land invertebrates would be far slower and less liable to accidental acceleration; they would be far less liable to question if used as evidence of land connections.

Terrestrial vertebrate fauna.-The greater mobility of vertebrate animals renders them far more fit to cope with minor changes in the environment and makes them at once better and worse indices of surrounding conditions; the highly developed power of locomotion and the ability to resist changes of temperature introduces no small factor of uncertainty. Far more elusive factors than the obvious ones so often cited above may determine the presence of such fossils far remote from their proper habitat. The migrations of birds, for instance, are governed by what we call instinct, and a study of the distribution of the remains of migratory birds would be a most formidable problem to future paleontologists. Disregarding in large measure all bar- 
riers of sea or land, climate or vegetation, the migratory flight takes them over wide areas of the earth's surface in a general north-and-south direction. Should any attempt be made in a later geological period to correlate the swamp deposits of to-day by the presence of the remains of the wild duck or the blackbird, for instance, it would be necessary to assume geographical conditions far from those which really exist. Here the time element would be correct, but all implications of geographical similarity would be utterly wrong. The changes of plumage which frequently accompany migratory movements or the changing seasons are superficial and no traces would remain in the fossil state.

Similarly, but over less distances, some grazing forms move with the seasons, following the grass, or water, or temperature changes. Carnivorous forms always follow the herds. Here the implication both of climate and geographical similarity might hold true whenever the remains were found in a determinable natural habitat, but, as suggested above, such forms might readily be swept far beyond their usual limits by flooded rivers, as when herds of bison were overcome on the Missouri or Mississippi Rivers and the cadavers swept away. The inference to be drawn from the occurrence of such forms is the work of experts.

\section{(c) Character of the Fauna.}

The nature of the beds and their surroundings is revealed by the contained fauna in large measure-marine, brackish, or fresh water; fluviatile, swamp, or terrestrial; arid or humid; plains, plateaus, woodland, or forest, etc. There facts are revealed by the structure of the animals which inhabit them. The general facts in such an interpretation are easily recognized, but the final interpretation depends on minute and exact knowledge. The best treatment of the matter is found in Abel's Paleobiologie and Lull's Organic Evolution. ${ }^{1}$

(d) Phylogenetic Relations of the Fauna.

The genetic relations of fossils are of the utmost significance not only in placing the beds in their proper position in the geological column, but for an understanding of the position of the fauna. The place of origin of the fauna, the connecting links which reveal the route of migration, and the separation of the constituent elements of a mixed fauna depend upon an understanding of their phylogeny. The mixed Devonian faunas known at Rochester, New York, or Milwaukee, Wisconsin, could only have been separated into their constituent parts by this means and the routes of migration of the different elements and the movements of the epicontinental seas of the time traced out.

1 Abel, Grundzüge der Paleobiologie der Wirbelthiere, Stuttgart, I9I2.

Lull, R. S., Organic Evolution, 1917. 
The stages of development of the various phyla represented frequently reveal differences in the time of geological horizons, otherwise indistinguishable. In the Red Beds (Permo-Carboniferous) of Texas and Oklahoma, a group of vertebrates occurs in a series of deposits indistinguishable from a series of beds in north central New Mexico carrying very similar vertebrates, but the difference in the age of the beds is revealed by the stage of evolution of the two genetically closely related groups.

\section{(e) Peculiarities of the Fauna.}

The peculiarities of a fauna, either aquatic or terrestrial, are revealed in the structure of the individual; such peculiarities are generally in close response to the conditions of life. It would require a long treatise to discuss the subject with any approach to adequacy, but on the solution of a paleogeographic problem where so much must be determined by indirect evidence it is necessary to exert the keenest observation to detect every suggestion. All the influence of the organic and inorganic world is reflected in the armor, mimetic adaptations, weapons, feeding adapta'tions, modes of progression, etc. Here the works of Abel, Walther (parts I and II), Lull, and Grabau (chap. 28) already cited are most useful.

It is not alone in response to the environment that peculiarities appear. As Beecher has shown, the approaching end of the life of a group is heralded by changes of a marked character in the constituent individuals, as the assumption of spines, excrescences, etc., and though he drew his illustration largely from invertebrates, the same thing can be shown for vertebrates. ${ }^{1}$ Provincial or cosmopolitan character in a fauna is revealed by its constituent members. Peculiarities of development shown in minor unique variations, strongly accentuated peculiarities of structure, or even a dominant character or direction of variation in the whole fauna, as thinness or thickness of shell, pauperization, etc., all point to a provincial character. The discovery of such characters would at once direct attention to the examination of all the other observable facts concerning the unit to test the suggestion of local, isolated deposits, as in a region of gulfs or bays, lagoons, and small inland seas, or, for terrestrial forms, isolated peaks, valleys, patches of woodlands, oases in a desert, etc. ${ }^{2}$

A greater community of structure in the fauna with less evidence of peculiarities not (immediately) explainable by use suggests wide areas of similar conditions where the friction of readily commingled forms from farseparated areas tends to maintain the mean of life. Such are the marine

${ }^{1}$ Beecher, C. E., Origin and Significance of Spines: A Study in Evolution. Amer. Jour. Sci., vol. vI, 4th series, I 898.

Case, E. C., The Permo-Carboniferous Red Beds of North America and Their Vertebrate fauna. Carnegie Inst. Wash. Pub. No. 207, p. III, 1915.

${ }^{2}$ The isolation of the group may be accomplished by more obscure factors than the purely geographical, as temperature, pressure, strength of waves, etc. 
invertebrate faunas of the Niagara limestone, the saurians of the Jurassic and Cretaceous, or the very similar mammalian faun $æ^{1}$ of certain stages of the Tertiary.

\section{( $f$ ) Radiation and Depression of Life.}

Circumstances of variable kinds have determined the abundance or paucity of life at irregular intervals of the world history. By radiation is understood the increase not only in number of individuals, but of varieties, species, genera, and even large groups, reaching out in all directions to find unoccupied niches in the scheme of existence where food or protection, breeding-places or homes, might be enjoyed with the minimum of loss. Osborn has called this, very aptly, "adaptive radiation." 2

Radiations are of two kinds. The greater radiations of the Classes of animal life, where each successively - fish, amphibian, reptile, and mammalasserted the dominance conferred by superior endowments in organization and for a time reigned as masters of the world. These radiations, which have given rise to such terms as age of fishes, age of amphibians, age of reptiles, age of mammals, were the result of the operation of the law of continuous improvement in life and has a broad but important bearing on the paleogeographic problem as it was during the periods of expansion of each group that the closest response to the environment was developed.

Lesser radiations were governed by more evident factors and the discovery of a unit containing an unusual number of individuals, varieties, or species of any smaller group of life should direct inquiry into the cause, and this may well be the key to the geographic conditions of the time. Such radiations may follow the entrance of a migrant fauna into a new region where enemies do not exist or are not in sufficient numbers to restrain the natural increase. Classic examples from our own experience are the remarkable increase of the English sparrow, the cotton-boll weevil, or the San José scale in America, or the rabbits in Australia. Climatic or surface changes, followed by the inevitable alteration of the vegetation, might give the advantage to a small or large group and start it upon a career of supremacy. ${ }^{3}$

Depressions of life are the exact correlatives of the radiations. Untoward physical conditions, such as the increasing salinity of the remnant seas of late Silurian time or the unknown conditions which caused the decrease of the Pelmatozoa in the Permian, illustrate this point. One has but to think of the effect of great droughts or blizzards on the plains of Argentina, Patagonia, North America, and Australia to realize what severe climatic changes may do. The introduction of enemies, as the trypanosomes of the sleeping sickness in Africa, or the immigration of dominating forms, may

${ }^{1}$ Osborn, H. F., Age of Mammals, p. 96 and following.

${ }^{2}$ Osborn, H. F., The Law of Adaptive Radiation, Amer. Nat., vol..36, p. 353, 1902, and Age of Mammals, p. 22.

${ }^{3}$ Osborn, in the article cited above, gives examples of adaptive radiations in the food habits and mode of locomotion. 
cause the complete or nearly complete exhaustion of a group. It would be unfortunate, however, if an investigator were to be hasty in his conclusions that the absence or diminished numbers of individuals or varieties of any group in an observed portion of a unit implied such a condition. The absence of fossils within the commonly restricted limits of any exposure of a unit by no means implies the lack of an abundance of life during that interval of time. The life of the ocean, fresh water, or land is far from uniformly distributed, even in places where conditions are seemingly identical, and one can not doubt that similar irregularities of distribution prevailed in past time. Recognizing the eminently accidental way in which animal remains, especially terrestrial forms, become preserved as fossils, a depression of life should be considered as demonstrated only after the most thorough search. Moreover, certain types of life may be driven out over large areas and still exist in favorable localities elsewhere, as when the upper Silurian fauna, depressed in the northern United States, found a "bay of refuge" in the Gaspé region of Canada; nor can we doubt that, though no great number of crinoids have been found in Permian deposits, somewhere, as yet unobserved, this branch of the animal kingdom maintained the stream of life to reappear as an important factor in the Mesozoic.

\section{(g) The Interrelations of the Fauna.}

No small factor in the solution of a paleogeographic problem is the relation which each separate group or member of the fauna bears to others. Parasitism renders some forms entirely dependent on the host, and undoubtedly the characters and habits of the host are affected by the parasites. How important this is has been amply demonstrated in modern times, where diseases carried by parasites have depopulated whole areas. The sleepingsickness trypanosome has practically extinguished human life in parts of Africa by causing death or migration; the rinderpest wrought havoc with the game in Africa; the Texas fever killed whole herds of animals in our own Southwest; parallels to such extreme cases undoubtedly occurred in past time and may have been the cause of the extinction or change of many forms of life, both vertebrate and invertebrate. But it is not only in the extreme cases that parasitism has had its effect. Groups large and small have changed their habits and form by the assumption of parasitic habits which were fatal to neither parasite nor host.

Commensalism plays an important part in the modification of structure and habits and was equally influential in the past. Some forms can only live in connection with other forms, as in the body-cavities of other animals or with them in caves, burrows, holes, etc. The little fish Fierasfer lives in the branchial chamber of the sea-cucumber, and certain sponges grow only on the backs and legs of certain crabs; the leptoline Hydractina grows on the shells of hermit crabs, etc. In these cases one form does not prey 
upon the other, but the two live in very constant association, each conferring some benefit upon the other. Such associations are not uncommon in fossils. An interesting paper by J. M. Clarke cites several instances of both parasitism and commensalism among extinct forms. ${ }^{1}$

Other relations than the two above should not be neglected. Prominent among the effects of interrelation are the adaptations of the carnivorous and herbivorous fauna to each other. Where two such groups have lived together for a sufficient time for the relations of one to the other to become well established, extreme and perfect adaptations of structure are to be expected-the means of defense by armor, thickened shells, mimicry, concealment, etc., will have reached a notable degree of development, while the carnivorous forms will exhibit equally extreme adaptations to overcoming the defense. If the fauna is a new one, or if two faunæ have been recently brought together by wide migration or the transgression of a sea into an inland basin or another sea, the relations will be more simple. The measure of perfection in the balance between offense and defense will beyond doubt give some clue to the length of time the whole fauna has been established.

It is less probable that forms will be found which have failed to become adapted more or less accurately to the physical surroundings, as they have in most cases experienced no sudden change, but in the case of suddenly increasing salinity of sea-water or the relatively sudden transgression of a sea over a lowland such conditions might be discovered. Dacqué tells us that changes in facies, organic or inorganic, are gradual; changes between beds are sudden.

No study of an extinct fauna would be complete were we to neglect to balance all conclusions drawn from structure against the presence of the features indicated. For instance, the food of a vertebrate may commonly be inferred from the character of the teeth-carnivorous (molluscivorous, durophagous, conchifragous, etc.), herbivorous, or omnivorous. Rodent teeth, browsing teeth, grazing teeth, etc., all imply definite feeding habits. Such observations should be checked by a search for the possible food-supply if it is believed that the remains occur in the original habitat. Frequently it is possible to determine by a comparison of the armor and the weapons of offense which animal has been selected as a prey by definite raptorial forms. It has been suggested that the growing length of the teeth of the saber-toothed tiger was correlated with the increasing thickness of the carapace of the glyptodonts and that in the Permian vertebrates of North America the development of strong tusks in Dimetrodon may have been associated with the development of armor in many of the amphibians and smaller reptiles.

1 Clarke, J. M., The Beginnings of Dependent Life. N. Y. State Museum Bull. I2I, p. 146, 1908. 
The possibility of error is clearly illustrated in the occurrence in the midTertiary of forms (the Ancyclopoda) undoubtedly ungulate in most characters, but with strong clawed feet. Such exceptions to the general rules are rare, but the exceptions serve to compel caution. The inferences drawn from one portion of the skeleton of these animals - and fragmentary skeletons are by far the most common remains of vertebrates-would be at total variance with those drawn from another part. ${ }^{1}$

Similar examples could be drawn in large numbers from among the invertebrates, although the specializations and adaptations are not always so striking.

\section{(h) Faunal Elements as Time-Markers.}

Obvious enough to the trained stratigrapher, it is still important to warn other workers of the varying value of fossils as indicators of passing time and changing conditions. Such forms as the brachiopod Lingula and the star-fishes are classical examples of genera and groups that have remained unchanged through long periods of time and are valueless as time-markers unless the most careful specific and varietal determinations are made. Other more plastic forms, as the ammonites of the Mesozoic, record in their rapid changes short intervals of time and rapid and slight changes of environment. Caution is also necessary in accepting as archaic, types which recall ancient forms of life. The Tuatara lizard Sphenodon, of New Zealand, long regarded as an example of a survival from Mesozoic or even late Paleozoic times, is now under suspicion as possibly being very specialized, with but few very archaic characters. ${ }^{2}$

\section{(i) The Flora of the Unit.}

Much that has been said concerning the fauna of any unit is equally true of the flora, and similar checks must be used in interpreting the fossil remains.

One difference between the animal and plant worlds has been given great weight in all considerations of paleogeography, that is, the comparative immobility of plants. For this reason they have been considered as especially good measures of climate and climatic fluctuations. This idea must not, however, remain unchallenged. Attention has often been brought to the fact that invertebrates, the most common resource of stratigraphers, are dispersed by forces entirely independent of their own motile powers. Eggs and free-swimming embryos of fixed forms are dispersed by currents of water or air; adult individuals of non-sessile kind are equally readily swept into new regions; their ultimate extinction or preservation in the new region is entirely independent of the mode of migration. Even vertebrates,

\footnotetext{
${ }^{1}$ Scott, W. B., Land Mammals of the Western Hemisphere, pp. 353 and 383, I9I3.

2 Ruedemann, R., The Paleontology of Arrested Evolution. N. Y. State Museum Bull. No. I96, I9I 8.
} 
the most mobile of the all, are not infrequently driven by external forces into new regions. The migration of these animals is thus far equally passive with that of plants.

Turning to plants and attempting to summarize the powers effecting their passive dispersal, we find a large and imposing array. Among others, spores and light seeds are carried by moving currents of air for great distances, heavier seeds are floated, or carried in the intestines of migrating animals, or attached to their bodies, to be dropped at great distances. The chances of survival are neither greater nor less in the new environments than are those of transported animals. To assume that the flora of a region has always reached any particular place by the slow process of self-seeding under the influence of a slow-shifting climate would be most erroneous. On the other hand, it would be equally dangerous to assume that a climatic change comes slowly or suddenly upon a restricted area and remains to influence it, and that the plants indicate an area of climatic isolation with unchanging boundaries. It has been repeatedly shown how climatic changes advance broadly over wide areas in a slow but irresistible march, and the flora may advance or disappear by self-seeding or death in an equally gradual manner. An excellent illustration of a relatively sudden climatic change has been given by Marais. ${ }^{1}$ Typical illustrations of more slow and regular changes are given by Huntington. ${ }^{2}$

The fact that the flora of any period of geological time is frequently in advance of the fauna in its evolution is well known; the controversy as to the upper limits of the Cretaceous hangs entirely upon the evaluation of the floral and faunal evidence. ${ }^{3}$ Other cases of a similar kind are well known. May it not be that slowly advancing climatic changes have permitted plants to advance into new regions, where the greater adaptability of the vertebrate forms permitted older types to persist for a long time in slightly changed conditions?

The interpretation of the adaptations of plants to environment is in the hands of the botanists, but one example of possible confusion may be cited: Desert plants are protected by a heavy layer of thickened peripheral cellspalisade cells-and the stomata are set in deep grooves, protected by hairs or wax, or practically closed. These are adaptations to prevent rapid evaporation, but similar histologic conditions are found in some plants of stagnant swamps. It is suggested that this is to prevent rapid evaporation and so prevent the plant from absorbing too large a quantity of poisonous

${ }^{1}$ Marais, E. N., Notes on Some Effects of Extreme Drought in Waterberg, South Africa, Agricultural Journal of South Africa, February 1914. Reprinted in Annual Report Secretary Smithsonian Institution for I9I4, p. 51 I.

${ }^{2}$ Huntington, E., The Pulse of Asia.

Some Characteristics of the Glacial Period in Non-Glacial Regions. Bull. Geol. Soc. Amer., vol. 18, p. 35I, I907.

${ }^{3}$ A Symposium upon the Cretaceous-Tertiary Boundary Line. Papers by Osborn, Knowlton, Stanton, Brown, Matthew, in Bull. Geol. Soc. Amer., vol. 25, pp. 321-402, I 914. 
water. Succulent plants occur in deserts, but also in purely aquatic habitat, and when only an impression of the fossil form is preserved the interpretation is difficult or impossible. The best general-source books are Schimper's Plant Geography and Clement's Plant Succession. ${ }^{1}$

Spalding has drawn attention to the fact that a desert environment is a most complex conception. Ranging from very moist along stream-courses, where willows and arrow-leaves may abound, through less damp soil to true desert and the high, dry débris slopes of neighboring mountains, with cactus, greasewood, chaparral, and sagebrush. There is but one common factor-the hot, "dry winds and the intense insolation. All plants of arid or semiarid regions, even in the damp parts, have coriaceous, heavy, or otherwise xerophilous leaf-structure. ${ }^{2}$

Nathorst, in discussing the vegetation of arctic regions as an index of climate, quotes remarks by Gotham showing that the wood of Cretaceous trees found in Spitzbergen possesses more definite rings of growth than those of equal age in Europe, and considers this as an evidence that the trees were grown in place, in the region of more accentuated climate, and not drifted in from the south, where the climate was more equable. ${ }^{3}$

Saporta showed that as general humidity increases the proportion of monocotyledons increases and of dicotyledons decreases. Lowering the temperature has the same effect. A dry and warm country has more dicotyledons than a warm and moist or cold and moist country. He also showed that an abundance of Leguminosæ suggest warm and dry conditions, and that under the same conditions there will be a feeble development of appendicular organs-coriaceous leaves with frequently spiny margins and a great complication of the nervation. How uncertain the revelation by plants may be, however, is shown by Schimper, who, in his Java Flora, demonstrates that xerophilous adaptations of similar character are found in xerophiles, halophytes, the Java alpine flora, and evergreen woody plants of colder climates. Obviously the interpretation from any but the Tertiary plants must be of the most tentative character.

Bailey and Sinnot $t^{4}$ have shown a remarkable relation between the form of leaves and climatic conditions. In their summary they say:

"There is a clearly marked correlation between leaf margins and environment in the distribution of dicotyledons in the various regions of the earth. Leaves and leaflets with entire margins are overwhelmingly predominant in the lowland

${ }^{1}$ Clements, F. E., Plant Succession: An Analysis of the Development of Vegetation, Carnegie Inst. Wash. Pub. No. 242, 1916.

${ }^{2}$ Spalding, V. H., Present Problems in Plant Ecology: Problems of Local Distribution in Arid Regions, Amer. Nat., vol. 43, I909. Reprinted in Annual Report Secretary Smithsonian Institution for I909, p. 453, I910.

${ }^{3}$ Nathorst, A. G., On the Value of the Forest Floras of the Arctic Regions as Evidence of Geological Climate, Annual Report Secretary Smithsonian Institution for I9II, p. 335. In this article many illustrations are given of the use of trees as indices of climate.

${ }^{4}$ Bailey, I. W., and E. W. Sinnott, The Climatic Distribution of Certain Types of Angiosperm Leaves, Amer. Jour. Bot., vol. III, p. 23, I9I6. 
tropical regions; those with non-entire margins in mesophytic cold temperate regions."

They show also that entire leaves occur in tropical and subtropical regions and in frigid regions, while non-entire leaves occur in cold temperate regions. A study of Tertiary and Cretaceous dicotyledon leaves leads them to state that this generalization "affords a simple and rapid means of gauging the general climatic conditions which existed in regions where these plants flourished."

Another observation has been made which should be kept constantly in mind-the effect of altitude upon both animal and plant life. This has been in part discussed above. All degrees of humidity are found at the different levels, the factors of temperature and pressure alone decreasing constantly as the elevation increases, and the character of the flora with reference to those, aside from the more variable factors, must be determined as an isolated fact. ${ }^{1}$

\section{CORRELATION OF THE UNIT WITH OTHER BEDS.}

The correlation of the beds is a most necessary step in the solution of the problem and also one of the most difficult in many cases. The criteria of correlation as given by Ulrich include diastrophic movements; evidence of sea-filling and tidal flats; by fossils; by lithologic similarity; by probabilities depending on rhythm of movement; by unconformities, overlaps, and hiatuses. ${ }^{2}$ To these should be added the tracing of actual continuity.

When the surface is obscured by vegetation or soil the separation of exposures even for limited distances may lead to error, especially when the unit to be traced is variable in character, as a delta or flood-plain deposit. In many places where the beds by reason of aridity and exposure are laid bare to the eye for miles it is very difficult to follow a deposit because of the rapidly changing character of its inorganic content. Individual beds in the Permo-Carboniferous, Triassic, and Jurassic Red Beds, even when exposed on the face of a naked cliff or on a bare flat, may not be followed for more than a short distance in many places. When, as in Kansas, Oklahoma, or Texas, these exposures are interrupted by areas of grassland or soil, the difficulty is enormously increased. Many of the older deposits in the eastern United States are of the same character, and any attempt to strictly correlate separate exposures in a region of heavy soil, grassland, or thick woods is sure to lead to very questionable results.

Similarly, but in even higher degree, efforts to correlate beds by samples from drilled or bored wells are open to question. The persistence of similar characters in a unit over great areas must be established before isolated

1 Seward, A. C., Fossil Plants as Tests of Climate. London, I892.

${ }^{2}$ Ulrich, E. O., Revision of the Paleozoic Systems, Bull. Geol. Soc. Amer., vol. 22, p. 394. (Index in vol. 24, p. $625,1913$. 
outcrops can be considered as establishing continuity. For well-established units of known and persistent character and in regions of continuous exposure the method leads to incontrovertable results.

Correlation by the fossil content is by far the most commonly applicable, but the method of applying the evidence is still in dispute. For the correlation of closely adjacent exposures the identity of faunæ or floræ is an unquestioned proof of contemporaneity, but the farther the exposures are separated the more shrewdly the evidence must be questioned. The question of contemporaneity rersus homotaxy has been thoroughly discussed, and one would hesitate to connect far separate areas as parts of the same unit by the simple presence of even closely similar fossils. The character of the fossils must of course be considered; floating forms readily dispersed by currents may spread over a large portion of the earth within the time of the deposition of even a thin unit. So much has been claimed for the graptolites, and Ulrich has shown how relatively rapidly even mollusks may be dispersed. ${ }^{1}$

Another phase of the question of correlation by fossil content is the discussion as to the relative importance of unique or common species. Is contemporaneity to be judged by the common occurrence of a large proportion of similar species, "matching species," or by the common occurrence of a few peculiar species? The pros and cons of this important question are taken up in papers by Ulrich, Williams, and Grabau. ${ }^{2}$

Correlation by inorganic contents-similar mineral or lithological features-has proven of value in limited and closely connected exposures, but for areas separated by any considerable interval it has been too frequently shown of no value to carry any significance of contemporaneity, though the value of such evidence as suggesting similar conditions of deposition is unquestioned.

Correlations of beds by the size of material, content, and depth of weathering have been applied to the solution of problems in climatic changes and terrace formation and destruction; also to the age of glacial deposit. The arguments suggested by the authors cited may be extended to the interpretation of more ancient deposits in favorable cases. For a discussion of the value of diastrophic changes in correlation the student is referred to the citation from Ulrich given above.

\section{CLIMATOLOGY OF THE PAST.}

The climatological changes of the past most obviously recorded are those of the great extremes, as in periods of local or regional glaciation where

\footnotetext{
${ }^{1}$ Ulrich, E. O., Revision of the Paleozoic Systems, pp. 295 and 575.

2 Ulrich, E. O., Revision of Paleozoic Systems.

Williams, H. S., Correlation Problems Suggested by the Eastport Quadrangle, Maine, Bull. Geol. Soc. Amer., vol. 24, p. 337, 1913. 
accumulations of tillite and other glacial débris of all kinds are generally readily recognized. That even such extremes have not left indisputable records is apparent to all who are familiar with the controversial literature which has grown up around these phenomena.

It has been demonstrated beyond dispute that in various periods of the earth's history, from Pre-Cambrian to the Pleistocene, there have been periods of refrigeration and ice accumulation either as local or continental glaciers. It is equally obvious, however, that up to at least the close of the Paleozoic conditions prevailed at times which permitted a uniform distribution of plants and animals over the surface of the earth under uniform conditions. ${ }^{1}$

The obvious result of such an apparent conflict of evidence for and against climatic variability in Paleozoic time is to invalidate to some extent the evidence on either hand or to enormously increase our conception of the imperfection of the geological record. The latter alternative would lead us to increase the estimate of past time by an amount sufficient to permit repeated revolutions of enormous extent and at the same time to postulate a total loss of any record of such revolutions. The "geological record," while imperfect, shows no hiatuses of this order in the Paleozoic era. We are permitted to accept with some assurance the general notion that the climate or climates of any period or smaller division of time were influenced by local (at least in time) conditions and dismiss in large measure from consideration, as practical problems of the paleogeography of single units, the broad problems of climatic revolution, except in certain stages where a world change is demonstrable, as at the close of the Paleozoic and in the Pleistocene. ${ }^{2}$

\section{DISTRIBUTION OF THE FAUNA AND FLORA.}

\section{(a) Provincial or Cosmopolitan.}

The fauna or flora of any unit may be peculiar in a greater or lesser degree to that unit, or they may be part of a widely distributed whole. Such isolation or wide distribution may be due to characters inherent in the animals or plants themselves, or to the character of the inorganic environment.

(b) Distribution Dependent on the Character of the Biota.

Animals or plants may become widely distributed, due to some peculiar resistance or adaptability in themselves which permits them to achieve success in widely different environments, as the rats and mice, the Canada

1 White, David, and F. H. Knowlton, Evidences of Paleobotany as to Geological Climate, Science, vol. 3I, p. 760, I9Io.

${ }^{2}$ Schuchert, Charles, Climates of Geological Time, Carnegie Inst. Wash. Pub. I92, pt. II, chap. XXI, I9I4, with bibliography.

Dacqué, Grundlagen und Methoden der Paläogeographie, chap. x.

Clements, E. F., Plant Succession, Carnegie Inst. Wash. Pub. No. 242, chap. XII, I9I6. 
thistle, or the prickly pear cactus of to-day, which have spread into regions differing notably in climate, soil, and altitude. To infer anything in particular from the location of such forms would be to strike the mark only very broadly. One is inclined to believe that the Paleozoic brachiopod Atrypa reticularis ${ }^{1}$ may have been equally hardy. Such widely distributed forms can not be considered as good indices of local conditions unless they possess some known character which has determined their distribution. On the other hand, sparsely distributed forms may reveal much if they are correctly understood. Sparseness of a given form may be due to either rapid evolution or to restricted powers of adaptation.

In the first case, forms which are undergoing rapid change may appear uncommon because of the really limited numbers of individuals referable to a given species. A classical example is the large series of ammonites in the Mesozoic. The discovery of but a few individuals or a single species, or to find them in a single unit, does not necessarily imply that they were restricted to any given locality by a definite set of conditions; they may have had a very wide range, but have been only locally preserved under favorable conditions and have disappeared by actual evolution before such conditions arose in other places. If, however, the forms are not a part of a rapidly changing series, but are highly specialized members of a normally stable group, their value as indices is high.

\section{(c) Distribution Dependent on the Inorganic Environment.}

Forms may be restricted or dispersed by entirely extrinsic forces, though this may be in part due to the nature of the animal or plant. Such floating forms as some aquatic plants, pelagic animals, colonies, as of graptolites, etc., may be closely confined within certain limits of the temperature and food-supply of currents, but due to the space covered by such currents and to the shifting of the currents they might come to be widely dispersed over the earth and occur in a great variety of deposits of a very different character. Could we understand them fully they would tell much concerning the peculiar environment which favored them, but it would be very erroneous to assume similarity of conditions over broad areas in all places where they are found fossil. The shifting of the Gulf Stream and the polar currents are well known, and they bear a life peculiar to themselves; but it is obvious that they drop the remains of the fauna and flora peculiar to themselves among widely different assemblages of more fixed forms.

Other less mobile or movable forms found widely dispersed are clearly indicative of similar conditions over wide areas, as the fauna of Niagara time.

${ }^{1}$ See also Ruedemann, Rudolf, The Paleontology of Arrested Evolution, N. Y. State Museum Bull. I96, I916. 


\section{(d) Migration.}

By migration must be understood the gradual movement of living forms toward a more favorable environment or their extension within such an environment. Large accumulations of fossils, especially those of one kind or a limited number of kinds, are commonly due to the relatively sudden action of some force catastrophic in nature and results. Frequently this happens when under the stress of conditions such as a severe storm, unusual conditions of heat or cold, aridity or drought, shifting currents or introduction of great quantities of sediment into a body of water, the more mobile forms are suddenly forced into unfavorable surroundings and perish. Such catastrophes are not migrations, nor are they to be interpreted as revealing conditions other than accidental. Great accumulations of fossil material other than of such forms as habitually grow in masses, beds, or reefs, as corals or bryozoa, shell-beds, or forest accumulations, are to be looked upon as unnatural and interpreted with much care.

True migrations are movements in mass of a group of animals or plants and are induced and checked by extrinsic factors. Even in the case of the periodic movements of birds and grazing animals, or the more sporadic movements of the lemmings, locusts, etc., the annual or periodical recurrence of the instinct of movement is revived by external factors.

In animals the migration may be active or passive. Increasing numbers may cause a peripheral pressure which will force individuals ever farther from the original seat of the group until checked by impassable barriers of some kind. ${ }^{1}$ Such a migration is generally in one direction and positive in character, $i$. e., there is no advance and retreat, as in the "migration" of birds, grazing animals, etc. It may be relatively sudden, as when a barrier is removed from in front of a group experiencing strong peripheral pressure, as when the Isthmus of Panama was formed or the Behring Straits closed, or when a land barrier between two bodies of water is broken down; or it may be slow and regular, as when a climatic change converts a plain into a forest region or vice versa, or when a sea creeps over the land.

Passive migration occurs where forms sedentary in the adult stage are free in the egg, embryonic, or young stages and are then borne by water or other currents to new regions. In this case the animals will go wherever the current goes and will persist and leave traces wherever the conditions are favorable. The same principle applies to forms free in the adult stage. This type of migration is the common thing among the marine invertebrates and is the form Ulrich has in mind when he announces his belief that little evolution has taken place within the epicontinental seas, but mostly in the ocean basins when the seas withdrew and the fauna migrated back upon the land when the sea returned.

${ }^{1}$ Scott, W. B., The Isthmus of Panama in Its Relation to the Animal Life of North and South America, Science, vol. 43, p. I I3, I9I6.

Matthew, W. D., Climate and Evolution, Annals N. Y. Acad. Sci., vol. XXIV, p. 177, 1915. 
Migration in plants is almost entirely passive; the seeds are carried by purely external agencies for a greater or less distance, and while the movement mayy be rapid in some cases, as with animals, it is apt to be very slow. Seward estimates the average amount of movement in forests by selfseeding as a yard a year, an amount that is practically negligible.

\section{(e) Autochthony (Originating in Place).}

The assumption that particular spots are the original home of certain forms and that they have migrated in certain definite directions has been made in a large number of cases. This assumption has, of course, placed the original home of any form or group at the locality where it is found lowest in the geological series and has traced the migrations by its appearance at higher levels in successive spots, but the method is open to objection in many regards. If Ulrich's assumption that evolution of the invertebrate forms has taken place in the ocean basins is correct, the first appearance in epicontinental sea deposits is to some extent accidental and the statement of direct migration is only, after all, a statement of where we know the fauna to occur at later dates. Such conclusions should be most tentatively stated. Indeed, if Urrich is correct, autochthony in observable regions would be very rare.

\section{(f) Accidental Introduction.}

By accidental introduction is meant the sporadic dispersal of individuals as opposed to the migration of an entire or a large portion of a fauna or flora. Such sporadic inclusions of unexpected elements may be the result of transmission of the living individuals or of the body after death. In the second case the condition will be revealed by the fact of the presence of but a few individuals or a single specimen and may be dismissed as accidental. Herein lies a grave danger. We have seen how bodies of plant material may be swept by normal streams, by floods, by wind storms, by high tides from one locality to another, and the remains preserved far from their natural habitat. If such occurrences are carelessly treated they may involve some erroneous conclusions of the first magnitude, especially if the observer is inclined to give heed to the presence of unique and peculiar forms in correlation rather than to the "matching of species." Premature assumptions regarding the removal of barriers or of migrations may easily arise.

In the first case, living forms may be carried by such accidents and find a favorable environment in which they will live and multiply to a remarkable extent. Cases of this form of dispersal across barriers and speculations as to other possibilities have multiplied to large numbers and it is unnecessary to repeat them. ${ }^{1}$ It may be recalled, as instances in point, that eggs and seeds are carried in the mud attached to the feet of aquatic

${ }^{1}$ Matthew, W. D., Climate and Evolution, Annals of N. Y. Acad. Sci., vol. xxiv, especially pp. 200-204, I915. 
birds, that storms may raise eggs or individual animals or plants high in the air and drop them at great distances; that seeds ingested by birds and other animals pass unharmed through the digestive tract; that animals may be carried upon drifting vegetable material across great bodies of water and that some seeds and nuts endure long immersion in salt water and may be carried great distances.

\section{(g) Extinction of a Flora or Fauna.}

Extinction of a flora or fauna may be caused by a variety of conditions. It is especially necessary that the student of stratigraphy recognize that it is frequently caused by entirely organic conditions, as the introduction of disease or the advent of powerful enemies which either attack and destroy the victims or preempt their food-supply or natural habitat. These things are generally effective upon only a portion of the fauna or flora, but may attack forms so dominant as to apparently alter the whole biota.

It would be totally unwarranted to assume that the sudden disappearance of the giant reptiles at the close of the Mesozoic or opening of the Tertiary, of the horse, mastodon, and elephant from North America in the Pleistocene was due entirely to inorganic changes, as climate, physiography, etc., which altered radically the conditions of all life. There is no evidence of a competent change in the inorganic world, and similar catastrophes have been traced to disease among living forms.

\section{(h) Survivals and Precipitate Development.}

Untoward conditions permit archaic forms to survive, as when regions are long free from disturbances of the inorganic conditions and are protected by barriers from the advent of destructive or competing forms. The faunas of the continents of Australia and South America are pertinent examples.

Other cases of long-lived groups, such as the genera Lingula, Atrypa, and Leptena, are apparently due to a peculiar hardihood inherent in the group and extraordinary powers of adaptation. It is obvious that such forms are as little adapted to use in determining the environment as they are in determining stratigraphic units. ${ }^{1}$

Precipitate development is supposed to occur in the youth of a group, but this is not an invariable principle. Exuberant growth, as has been demonstrated, is caused by many factors, especially those which in some manner disturb the phylum. Adverse conditions produce such effects at times - cross-breeding such as might easily occur in regions crowded with plants or animals, the approaching extinction of a group - all these and others induce the appearance of new forms. In paleontology, where the determina-

${ }^{1}$ Ruedemann, Rudolf, The Paleontology of Arrested Evolution, N. Y. State Museum Bull. 196, 1916. 
tion of species is far less easy and definite than in recent biology, the appearance of new forms whose genesis and relationships are obscure must not be attributed solely to changes of the inorganic world.

\section{(i) Control of Distribution.}

To aquatic invertebrates the presence of land would seem an insurmountable barrier to all normal expansion, but it must be remembered that some of the crustacea usually aquatic have progressed so far toward a terrestrial life that they endure a surprising lack of water. The common crayfish (Astacus fluviatilis) has gone so far in this direction that it lives in very arid regions. The author has found active specimens of crayfish in little rills formed by recent rains upon the driest part of the plains, and found one vigorous specimen living among some damp rocks where the merest trickle of water preserved moisture. It is very probable that this process has been repeated many times in the past.

The majority of invertebrates found fossil are shallow-water forms, and to these a deep sea is as impassable a barrier as dry land. Shallow seas were probably far more common and widespread in the Paleozoic than in later times and the presence of similar members of shallow-water groups in remote localities is amply sufficient for the assumption of a shallow-water connection between the two places.

The term "barrier," however, involves a most complex conception. The presence of land and deep water are the simplest types of barriers to migration. Localized conditions of the water may form impassable barriers. Currents which have so much to do with the distribution of free-swimming forms and of larvæ would prevent the same forms from crossing them in anything like a direct path. Warm and cold currents would be as efficient barriers as equally marked extremes of temperature upon the land.

Alexander Agassiz reported an area almost devoid of life in the deep ocean waters off the west coast of South America. What the cause of this is we do not know, but for some reason the life has been barred off.

The waters of the Atlantic Ocean off the west coast of northern Africa are exceptionally saline, due to excessive evaporation. We can not doubt that in the nice adjustment of life this is an efficient barrier to some forms of life.

For land invertebrates and vertebrates the barriers would be of the same general kind. It is essential to recognize that it is not only the physiographic features which must be considered. Mountains, lakes, rivers, climate, deserts, etc., are important and effectual, but a stretch of grassland or a deep forest is as effectual to forms accustomed to an opposite type of habitat. Absence of food-supply is equally efficient, and animals may be restricted by a physiographic or hydrographic barrier which would be utterly inefficient in itself through its effect upon the vegetation. 
Moreover, animals are restricted by barriers as obscure as bacterial disease. Many forms of life are actually barred from regions in Africa where the tse-tse fly carries the trypanosome of sleeping sickness, and other parasites are almost equally effective. Man himself is only slowly winning past the barriers of tropical diseases to a vigorous health and growth in the intertropical regions.

Salt water is an effective barrier to amphibians, as it is fatal to the egg or adult of almost all forms.

\section{(j) Environment.}

Environment is the sum of all the contacts which an organism or a group of organisms establishes with the forces and matter of its surroundings, either organic or inorganic. With this the concept of isolation becomes much more complex. Complete isolation is unthinkable, but partial and effective isolation may be achieved by the acquisition of certain habits, certain physiological peculiarities or immunities, certain morphological characters, etc., which remove a form from a given number of contacts or neutralize their effect. Isolation is no longer to be thought of as accomplished solely by the presence of physical barriers. An individual or group which has developed immunity from a contagious disease may continue and exist in a state of isolation from a set of contacts which control the development of individuals or groups around it; physical peculiarities, habits, armor, etc., might have the same effect.

Such a state of isolation may amount to very perfect adaptation to the environment, and, as the author has suggested, ${ }^{1}$ may lead to extinction.

Any attempt at an analysis of the environment as thus conceived will at once lead to its separation into two main groups, the organic and the inorganic, both of which are susceptible to minute subdivision, and all subdivisions will show innumerable instances of a most complex interrelationship. At the same time, the environment may be divided in a tripartite manner -into those contacts which are favorable to the organism or group, those which are unfavorable, and those which are neutral or have no effect. The latter class will inevitably be very small, for so intimate are the interrelationships of all the forces and matter which surround any unit that the alteration of even the seemingly most negligible factor may have a farreaching effect upon the whole. In tabular form such an analysis may be set forth as follows:

Organic, favorable (hospitable).

Organic, unfavorable (inhospitable).

Organic, neutral.
Inorganic, favorable (hospitable)

Inorganic, unfavorable (inhospitable). Inorganic, neutral.

Organic contacts will be with other organisms, dead or alive. Such contacts are susceptible of almost endless subdivision and classification according

${ }^{1}$ Case, E. C., Carnegie Inst. Wash. Pub. No. 207, p. II5, I91 5. 
as the problem is approached from different angles. In a previous paper the author has suggested a scheme which seemed the best for his purposes: ${ }^{1}$

Favorable, hospitable. Active hospitality.

Passive hospitality.
Unfavorable, inhospitable.

Active inhospitality, antagonism.

Passive inhospitality.

Inorganic contacts may be classified under the same heads. Such contacts will be with the atmosphere, hydrosphere, and lithosphere; they will almost invariably take place, as Chamberlin has pointed out, at the surface of one of these or in a narrow zone where two of the spheres meet.

Contacts with the atmosphere will be both dynamic and static. The dynamic contacts will be with all the movements of the air which in any wise condition or effect the movements, life, or distribution of organisms. Temperature and pressure are commonly static factors, but in so far as either determines the movement of the air they must be reckoned as dynamic.

The static contacts with the atmosphere are the temperature (constant, annual average constant, annual average range, average seasonal variation, etc.; if there is a progressive change in any of these it will be an effective factor), the pressure, and the constitution (including the water-content or humidity).

Contacts with the hydrosphere will be essentially the same as with the atmosphere, as it is a mobile sphere; but there must be added the factor (largely static) of the change of state as the temperature fluctuates across the point determining solidification or liquefaction. Movements in icemasses would afford the same kind of contacts as with the lithosphere. The constitution of the water will afford a much greater variety of contacts than that of the air, because the water contains large and various quantities of material in solution, while the air is, so far as we know, a mechanical mixture of gases and the variation of its constituents is within a limited range.

Contacts with the lithosphere are predominantly static. Such qualities as hardness, texture, chemical and mineral composition, water-content, position and posture of rock layers and masses, depth of soil, etc., occur at once as important factors in the environment. Sudden movements in the lithosphere, as landslides, earthquakes, etc., are far too brief and localized to affect more than a portion of one generation, but may be effective as a dynamic factor in the extinction of a local fauna or flora. The slow movements resulting in soil accumulation and denudation are certainly effective in their influence on the evolution of a group, but are normally so slow that the condition in any unit of time, even a unit of considerable duration, may be regarded as fixed and the contacts will be static.

One other classification of the environment is valuable in realizing the effect upon life. An environment may be monotonous or diversified.

${ }^{1}$ Case, E. C., Ecological Factors of Evolution, Bull. Wis. Soc. Nat. Hist., vol. 3, n.s., pp. I69-180, I905. 
A monotonous environment is one where there is little change in the factors, static or dynamic, which form the group of contacts and into which no new elements are introduced and none are abstracted. Such an environment permits close adjustment of forms, but tends toward the perpetuation of archaic forms. The environment may be at the same time complex, relatively, and monotonous. In such a case there may be an accumulation of stresses which would cause rapid expansion and evolution of life when the status was disturbed. The depths of the sea, a desert, or a great plain would approximate this condition.

A diversified environment contains many shifting factors which continually introduce new elements into the problem, facilitating or inducing rapid and radical changes. A region undergoing climatic change, inundation by the sea, or elevation resulting in greater aridity, the spread or retreat of vegetation, etc., are illustrations.

With this very brief statement of the very comprehensive conception of the environment, it is obvious that almost every force or kind of matter must be reckoned with as a possible agent in the development of any group of organisms. Because of this complexity and the necessity for the consideration of combinations of factors, especially in the study of extinct forms of life, usually treated separately and only by specialists in widely divergent fields, it is obvious that the environment is the dominant element in any paleogeographic problem.

\section{CHECKS ON THE GEOLOGIST.}

It is obvious from the above that the solution of a paleogeographic problem involves far more than the discernment of the boundaries of deposits or the mapping of the occurrences of peculiar forms of life. Nor can the peculiarities of a fauna or flora be explained by the relation of the individuals of the biota to the inorganic environments alone.

The geologist who would restore the condition of the earth at any definite interval of time may not limit himself to the interaction and results of inorganic forces, for his restoration would be incomplete and far from accurate. Even if he designedly deals with such forces alone and desires to present only the incomplete picture, he is helpless to delimit the land and water areas without using indices supplied by the response of organic things. $\mathrm{He}$ is not entirely justified in his criticism of the biologist who would raise a continent to transfer a toad from one side of the sea to another, for after all the things are there and their presence must be explained, though the biologist may have been too enthusiastic in his epeirogenic efforts and too ready to refer the distribution to geological agencies.

The geologist may be far wrong in his interpretations of structures unless his knowledge of life is ample. The author again calls to notice his experience on an area of wind-blown sand in a desert portion of Arizona, 
where he found ripple-marks, thin-leaved stalks of vegetation, obscure insect tracks, and a series of sinuous convolute markings where some insect burrowing beneath the burning sand had thrown up a long trail indistinguishable from worm tracks at the bottom of a shallow body of water. He went over much of the area most carefully, certainly over far more than is normally exposed in a geological outcrop, and utterly failed to find a single criterion that would have prevented him from pronouncing the exposure an old sea-bottom or flood-plain if it had been found fossil, and yet the formation was going on before his very eyes on a sun-stricken bit of desert. The insect burrows would have unhesitatingly been called worm tracks; the insect tracks might have been made by any one of many aquatic forms instead of beetles or grasshoppers; the vegetation once fallen and recorded only as an imprint could not be told from a bit of aquatic vegetation. The wind ripples upon most careful analysis might have revealed their origin, but again, in the author's experience, sand collected in a delta deposit has been pronounced dunesand which had drifted into the water.

\section{CHECKS ON THE BIOLOGIST.}

Perhaps the greatest need by any worker in paleobiology is a comprehension of the nature of the movement of the land-masses. It is accepted by the majority of geologists that certain portions of the earth's surface have been dominantly land and elevated above the general level and that others have been peristently depressed and occupied by oceanic waters, but it is obvious to all that the lands have very frequently been covered by shallow seas and that portions of the present ocean basin were once dry land. That there has been law in the development of the present shape of the continents there can be little doubt, but this law is yet to be discovered and stated. The attention of paleobiologists is especially invited to the section following.

\section{(a) BRIDGES AND BARriers.}

The term "bridges" must be understood to include all possible means of normal voluntary movement by living forms of any kind between distinct areas. Commonly we think of land connections between bodies of land, but in the proper use of the term it must be applied to other conditionschannels between bodies of water, zones of climate, zones of equal altitude, zones of similar vegetation, etc.-anything which will permit migration or interchange of life. The term "barriers" must be given the same free interpretation. A "barrier" to some things will obviously be a "bridge" to others in many cases.

The conflict between the paleobiologist and geologist, at least in the present stage of both sciences, is largely confined to major questions of communication, or connection between large masses of land and water. The evidence of such "bridges" and "barriers" has largely been brought 
forward by the paleobiologists, in the presence of common fossils or the absence of groups in definite localities, but in some cases, at least, the physical geologists have given equally important evidence. The continent which occupied the North Atlantic Ocean basin is vouched for by both and its presence up to at least mid-Miocene fully accepted. The Mediterranean Tethys is equally well established. Gondwana Land and the Antarctic connection between Africa, Australia, and South America depend more definitely upon biological evidence and await full confirmation.

For a discussion of the general principles of the subject we may follow the majority of geologists in accepting the permanence of the great continental blocks and ocean basins and so dismiss for the time all questions of the movement of life forms upon the blocks or within the basins. Only the cases where "bridges" have been suggested as existing across permanent ocean basins need be mentioned.

The condition of the surface of the earth before Mesozoic time is, to say the least, uncertain. The tetrahedral theory suggests a practical reversal of the land and water conditions; ${ }^{1}$ in the Paleozoic the bulk of the land lay in the southern hemisphere; after the Paleozoic it lay in the northern, but the great Mediterranean Tethys lay always in an approximately equatorial position. If it shall ever be fully demonstrated that this reversal took place, we shall have a rational explanation for the proposition that land life of the Paleozoic developed largely in the southern hemisphere and migrated northward, while in the Mesozoic and Cenozoic the land life reached its maximum in the north and pressed southward. Somewhere must be found the bridge across the Tethys. Perhaps the edges of the tetrahedroid, which would be in the same position before and after the reversal, will reveal the clue. The deepening of the ocean basin in the Mesozoic, suggested by Walther, and the contraction and elevation of the continental blocks, suggested by Wegener, ${ }^{2}$ account for the present wide separation of the land by uncrossable barriers of deep sea; but these are but developments of previous conditions and it is not proven that the deepening of the basins took place in the Mesozoic.

The uncertainty as to the mode of origin of geosynclines and their later elevation into mountains of sedimentary rock introduces another element of uncertainty. Haug believes that such geosynclines lie between great continental masses and would use their presence as an evidence for the former existence of a continent in the Pacific Ocean basin; others contend only for their presence upon the edges of continental blocks. However this may be, such geosynclines to-day, so far as we can now determine, lie upon the edges of continental blocks and are the origin of bordering mountain ranges,

${ }^{1}$ Gregory, J. W., The Plan of the Earth and Its Causes, Geog. Jour., vol. XIII, p. 225, 1899. Reprint in Annual Report Secretary Smithsonian Institution for I898, p. 363.

${ }^{2}$ Dacqué, E., Gründlagen und Methoden der Paläogeographie, chaps. Iv, v, and vi. 
however the upheaval may have been accomplished. There is here a hint which may guide the paleobiologist in postulating land connections. Such ridges as are necessary should be drawn or searched for parallel to old lands or upon their edges. The old edges of the North Atlantic Continent are still traceable in the seacoast of Great Britain, France, and eastern Canada. Such evidence does not appear for Gondwana Land.

In examining some paleogeographic maps, as those drawn by Scharf, we find long bridges drawn parallel to the coast, as from the middle of western South America to the Galapagos Islands and north. Such suggestions seem at first to exceed the possibilities, as the geologist knows them, but there is a possible explanation in the conceptions of Wegener that the continents have decreased in size by constant contraction and elevation, and such ridges may have existed and parts been left behind as the major portion receded inward. Again, it is possible that previously exposed areas parallel to existing continental blocks have been obliterated in whole or in part by the "suboceanic shove" discussed by Ulrich, which he would demonstrate by the inward position of repeated uplifts in the geosynclinal region of the Appalachian Mountains. Opposed to such a conception is the idea of continental creep elaborated by Chamberlin; but as one force works outward from above and the other inward from below there would be a constant, if intermittent, movement down and in at the edge of the continental block which would not preclude the existence, temporarily at least, of parallel lands bordering the present blocks. Such conceptions are far more feasible than ridges flung boldly across what we know to have been permanent ocean basins.

Such broad questions are, however, only to be hinted at in a summary outline. Only extended consideration will permit the true weighing of the evidence. The author has found Dacque, "Grundlagen and Methoden der Palaogeographie," and Grabau, "Principles of Stratigraphy," excellent introductions to the literature of this subject. 



\section{CHAPTER II.}

\section{SUMMARY DESCRIPTION OF THE DIFFERENT PROVINCES OF NORTH AMERICA IN LATE PALEOZOIC TIME.}

The primary attempt in this part of the work is to isolate as definitely as may be a distinct interval of time and give such a description of the deposits included in that interval that the life and the various factors of the environment, organic and inorganic, which have influenced the life may be studied.

It is realized at the very outset that such an attempt is destined to only partial success, for the nature of the geological record is in many places such as to render the determination of the limits of the interval uncertain. In places the interval began in a time of terrestrial deposition and ended with the surface of the earth raised above the possibility of any accumulation and with the geological record exposed to the obliterating forces of erosion and the obscuration attendant on later earth-movements. In some other places the limits are equally uncertain, because of other unfortunate conditions.

Under the very uniform conditions of climate which, despite local abnormalities, prevailed over a large part of the earth's surface in the first part, at least, of the interval, it is necessary to consider very wide areas as units, and this introduces a new element of uncertainty, for while fairly accurate correlations are possible over limited areas, broader correlations are difficult and less certain, due to geographical interruptions in the exposure of the deposits.

In the first intention the interval of time proposed for the study of life was included in that which has been called by authors the Permian or PermoCarboniferous, but a very brief inspection of the stratigraphic data included in the various papers and reports made it evident that no stratigraphic limits could be assigned to this accepted interval which would coincide with the climatological, biological, and erosional evidence. From this arose the necessity of including in the consideration of the problem a considerable thickness of strata both above and below the limits originally set and an effort at correlation of conditions which were perhaps progressive in occurrence, rather than absolutely or approximately synchronous.

In any case, or by the application of any methods, the continent of North America shows three areas at the close of the Paleozoic within which fairly close approximate correlations may be made by stratigraphic and biologic evidence and between which correlations can only be made on climatological and erosional evidence. These areas are:

First, the upper Pennsylvanian and Permo-Carboniferous outcrops of the eastern half of the United States and Canada, here called the Eastern Province. 
Second, the upper Pennsylvanian and Permo-Carboniferous outcrops of the central and western portion of the United States east of the Front Ranges of the Rocky Mountains, defined in Publication 207 of the Carnegie Institution as the Plains Province.

Third, the upper Pennsylvanian and Permo-Carboniferous outcrops west of the Front Ranges of the Rocky Mountains, and possibly extending into British Columbia and Alaska, defined in Publication 207 as the Basin Province.

Between the first and second areas lie the uplift of southern Missouri and the regions directly north and south of it, which are now largely devoid of post-Mississippian deposits and probably never had any considerable amount of such deposits.

Between the second and third areas lie the outcrops of pre-Pennsylvanian rocks of the crests of the Rocky Mountain Front Ranges. It is not impossible that connection was established between these areas either at the north or the south end, or both ends, of the barrier, but the separation was sufficient, and sufficiently long sustained, to determine the deposition of very different material and the location of very different faunæ on the two sides, as is shown elsewhere in this work.

In describing the three provinces, the author has reduced the amount of descriptive material and the amount of quotations to a minimum consistent with an attempt to place the conditions before the reader. Much of the material is readily available in the reports of the geological surveys of the United States, Canada, and the various States, and excellent bibliographies will introduce the student to a very extensive literature. Older publications, whose value is largely historical, have been sparingly mentioned in the discussion, though a large number have been carefully considered for the many side lights which have borne such an important part in the preparation of the argument. In general, only the later papers which have summarized the evidence are quoted or discussed. Frequent references have been made to Publication 207 of the Carnegie Institution, where a part of the material has been presented, and its repetition seemed needless.

The accompanying correlation tables show the relation of the beds in the different provinces. It does not purport to be a statement of exact equivalence, but to show the general relation of the beds within limits sufficiently exact to support the thesis of this paper-that the conditions of red-bed deposition appeared at progressively higher levels from east to west. As is evident, the Pennsylvania and West Virginia sections have been taken as the standard for the Eastern Province and the Kansas section for the Western Province. The breaks between various areas render the exact correlation difficult and perhaps impossible, but are not beyond the possibility of bridging within usable limits. The main breaks in the Eastern Province are between the New England-Canadian area and the Pennsylvania-West Virginia area and between the latter and the Illinois-Western Kentucky area. 


\begin{tabular}{|c|c|c|c|c|c|c|c|c|}
\hline & Indiana. & Ohio. & \multicolumn{2}{|r|}{$\begin{array}{l}\begin{array}{l}\text { Pennsylvania and West } \\
\text { Virginia. }\end{array} \\
\text { Nineveh ls. } \\
\text { Nineveh coal } \\
\text { Claysville ls. } \\
\text { Dunkard? coal, etc. } \\
\text { Prosperity ls. } \\
\text { Tenmile coal } \\
\text { Donnely ls. }\end{array}$} & \multirow{2}{*}{$\begin{array}{c}\text { Massachusetts. } \\
\text { Cambridge slate } \\
\text { Roxbury conglomerate }\end{array}$} & \multirow[b]{2}{*}{\begin{tabular}{|c|} 
Rhode Island. \\
$\begin{array}{l}\text { Dighton conglomer- } \\
\text { ate } \\
\text { Purgatory conglom- } \\
\text { erate }\end{array}$
\end{tabular}} & \multirow[b]{2}{*}{$\begin{array}{l}\text { New Brunswick. } \\
\\
\text { New Glasgow con- } \\
\text { glomerate }\end{array}$} & \multirow[b]{2}{*}{$\begin{array}{l}\text { Prince Edward } \\
\text { Island. } \\
\\
\text { Red sandstone and } \\
\text { shale }\end{array}$} \\
\hline & $\begin{array}{l}\text { Rocks with the Aldrich } \\
\text { and Friendsville coal } \\
\text { Parker coal } \\
\text { Interval }\end{array}$ & & & $\begin{array}{l}\text { Nineveh ls. } \\
\text { Nineveh coal } \\
\text { Claysville ls. } \\
\text { Dunkard? coal, etc. } \\
\text { Prosperity ls. } \\
\text { Tenmile coal } \\
\text { Donnely ls. } \\
\\
\text { U. Washington ls. } \\
\text { Jollytown coal, etc. } \\
\text { M. Washington ls. } \\
\text { L. Washington ls. } \\
\text { Washington coal } \\
\text { Little Washington coal and } \\
\text { sandstone } \\
\text { Waynesburg A \& B coal, etc. } \\
\text { Cassville shale }\end{array}$ & & & & \\
\hline & $\begin{array}{l}\text { Interval } \\
\text { Ditney formation } \\
\text { Coal VIII } \\
\text { Somerville formation }\end{array}$ & & . & $\begin{array}{l}\text { Waynesburg coal } \\
\text { Brownstown ss. } \\
\text { Little Waynesburg coal } \\
\text { Waynesburg ls. } \\
\text { Uniontown ss. } \\
\text { Uniontown coal } \\
\text { Benwood ls. } \\
\text { Sewickley ss. } \\
\text { Sewickley coal } \\
\text { Fishport (Sewickley) ls. } \\
\text { Redstone coal } \\
\text { Pittsburg ss. } \\
\text { Pittsburg coal }\end{array}$ & 2. Dorchester slate & $\begin{array}{l}\text { Rhode Island forma- } \\
\text { tion }\end{array}$ & $\begin{array}{l}\text { Shulie formation. } \\
\text { (Possibly in part } \\
\text { equal to the New } \\
\text { Glasgow con- } \\
\text { glomerate) }\end{array}$ & $\begin{array}{l}\text { Red and gray sand- } \\
\text { stone and shale }\end{array}$ \\
\hline 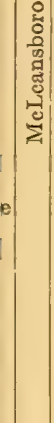 & $\begin{array}{l}\text { Millersburg formation } \\
\text { Coal VII }\end{array}$ & \begin{tabular}{|l|} 
Pittsburg ls. \\
Connellsville ss. \\
Morgantown ss. \\
Ames ls. \\
Harlem \\
Round Knob \\
Barton coal \\
Buffalo ss. \\
Brush Creek \\
Mahoning ss.
\end{tabular} & 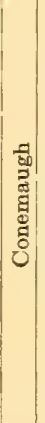 & $\begin{array}{l}\text { U. Pittsburg ls. } \\
\text { Little Pittsburg coal } \\
\text { Connellsville ss. } \\
\text { Little Clarksburg coal } \\
\text { Lonaconing coal } \\
\text { Morgantown ss. } \\
\text { Elk Lick coal } \\
\text { Ames ls. } \\
\text { Harlem coal } \\
\text { Pittsburg red shale } \\
\text { Maymardier coal } \\
\text { Saltsburg ss. } \\
\text { Bakerstown coal } \\
\text { Buffalo ss. } \\
\text { L. Cambridge coal } \\
\text { Gallitzin coal } \\
\text { Mahoning ls. } \\
\text { Mahoning ss. } \\
\text { Uffington sh. }\end{array}$ & & & Joggins formation & \\
\hline & & & & & & & & \\
\hline
\end{tabular}

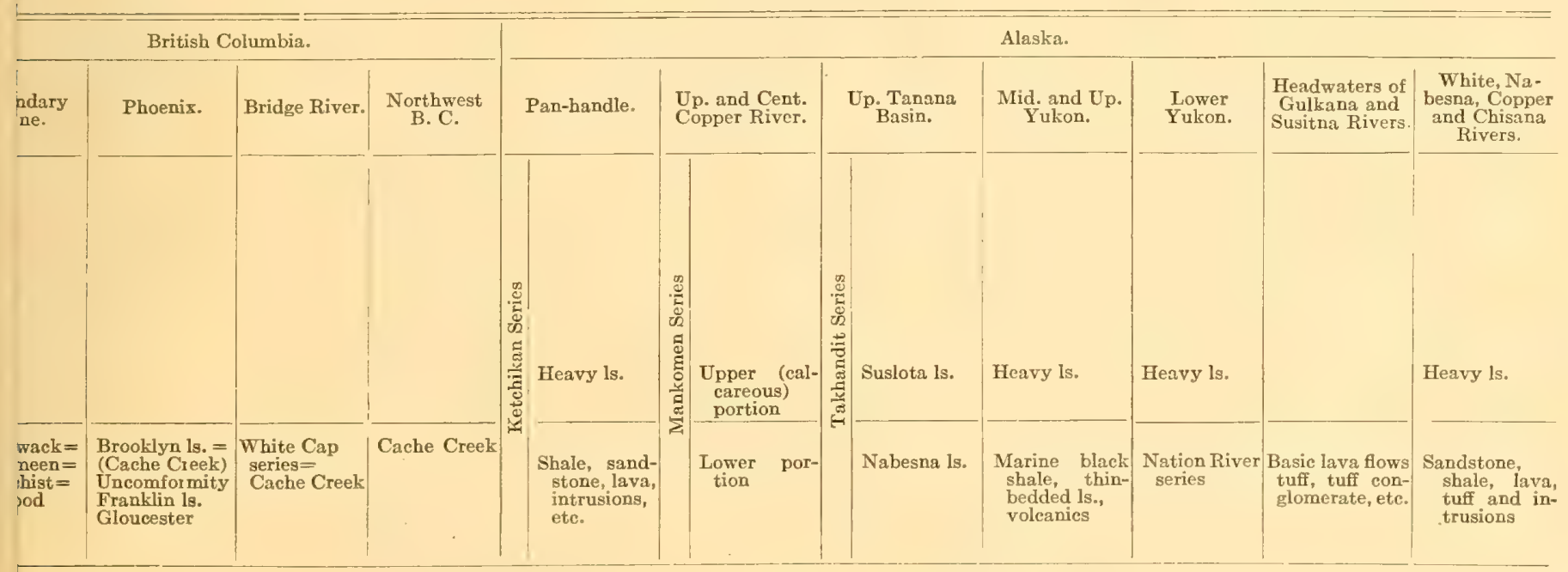



Correlation Table I.-Eastern and Planis Provinces.

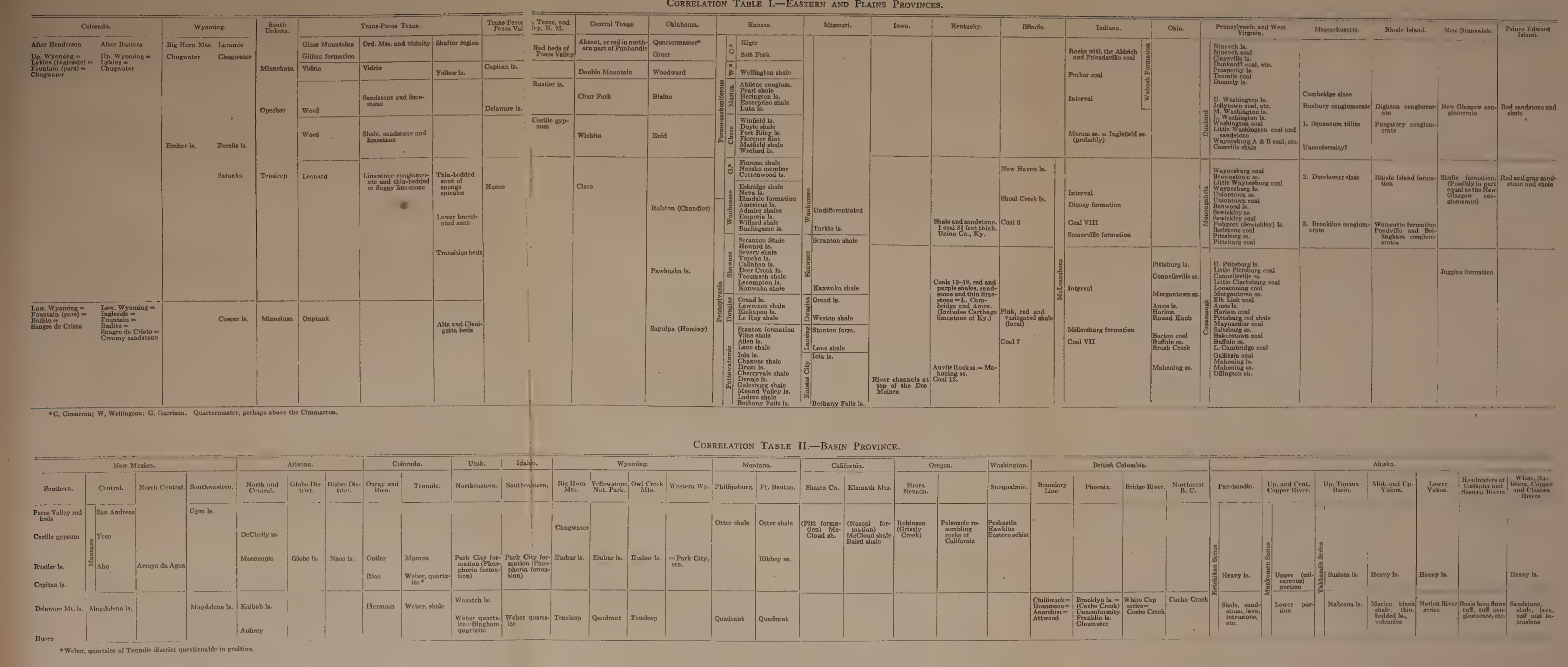



The break between the Eastern Province and the Plains Province is formed by the Missouri Island and between the Plains Province and the Basin Province by the Rocky Mountain Barrier. Both of these breaks may be less important from the fact that the beds may be traced around their northern or southern edges almost or completely to an actual connection. The northern limits of both the Plains and the Basin Provinces are not yet known, but it is very possible that both may be traced north of the United States-Canadian boundary. The break between the Basin Province deposits and the deposits of the British Columbia-Alaska-Pacific Coast area is only partially bridged at present, but this is of less significance, as the deposits of the last-named area are all proven with fair certainty to be below the level of red-bed deposition and are discussed in this work because of their bearing upon the general question and the possible routes of migration.

The correlations given in table I, for the Eastern and the Plains Provinces, show no considerable departure from the published and accepted correlation tables, except possibly in the New England and Canadian regions.

The position of the Carboniferous and Permo-Carboniferous deposits of the Massachusetts and Rhode Island areas is very uncertain. As shown in the summary description of the stratigraphy, the Cambridge slate and the Squantum tillite member of the Roxbury conglomerate are considered to be post-Pennsylvanian, and the Dighton conglomerate is regarded as of the same age, but the evidence for this is at best uncertain; these deposits may be much earlier. The New Glasgow conglomerate is certainly post-Joggins in age and in all probability close to the uppermost Massachusetts and Rhode Island deposits in stratigraphic position. The conglomerate beneath the red shales and sandstones of Prince Edward Island occupies a similar position.

The position of these four series in the correlation table is therefore only provisional, and there seems no reason why they might not have been much lower, for it is very possible that the same disturbances which originated the deposition of red beds in West Virginia and Pennsylvania might have caused the glaciation southeast of the Boston Basin and the elevation of the Cobequid Hills.

\section{A. THE EASTERN PROVINCE.}

The coal regions of West Virginia and Pennsylvania may be taken as the type regions of the province. A list in sequence of the principal layers of the upper Pennsylvanian and Permo-Carboniferous of these regions is given in the correlation table opposite page 48. Details of these formations, additional to those given below and in Publication No. 207 of the Carnegie Institution of Washington, may readily be found in the excellent reports of the geological surveys of West Virginia (coal reports), Pennsylvania, and the United States, and in the pages of the bulletin of the Geological Society of America. ${ }^{1}$

${ }^{1}$ Notably Stephenson, J. J., Bull. Geol. Soc. Amer., vol. I8, pp. 29-178, I907. 
Most of Pennsylvania, western West Virginia, and the adjacent portions of Ohio and Kentucky were occupied by a basin wherein continuous terrestrial deposition took place from about middle Conemaugh time on. It is commonly stated that no marine fossils are found above the Ames limestone, but I. C. White states that some have been found at slightly higher horizons. But no doubt it may be accepted that middle Conemaugh time saw the beginnings of new conditions in the type area of the Eastern Province.

A strong indication of this change of conditions is the presence of heavy layers of red shales and sandstones, as the Pittsburgh red shales in Pennsylvania and the equivalent horizons in West Virginia. It must be recognized that, as I. C. White has so strongly insisted, the change in the sediments marks a decided change in the environment of life, and though PermoCarboniferous (Permian) plant remains do not commonly occur until much higher horizons, the presence of favorable conditions can be recognized and the younger flora, and part, at least, of the fauna could now appear, either by development or migration.

It must be clearly understood that the author proceeds upon the thesis, right or wrong, that favorable conditions for any type of life or group of forms must precede the life forms, which follow either as determined by the direct action of the environment or as permitted by the environment, evolution being determined by other forces. If this be so, then an interval of geological time begins when the conditions fitted for the life of that time appear, not when the first typical fossils of the time appear, which may be at a somewhat or even considerably later date. From this it follows that to understand the life conditions of the closing period of the Paleozoic era it is necessary to start somewhat further back than is ordinarily done.

In order to describe most clearly the conditions of the Eastern Province, it is desirable to divide it into two subprovinces-a Northeastern Subprovince, including New England and the Maritime Provinces of Canada, and a Southern Subprovince, including Pennsylvania, West Virginia, Ohio, Indiana, Illinois, and Kentucky. To the latter subprovince belongs, perhaps, Michigan, though deposits of that State have added nothing to the discussion or solution of the question.

The deposits of these two areas are separated by a considerable interval occupied by both older and younger rocks, and it is questionable if they were ever connected, but the similarity of the deposits is such as to permit a correlation of the conditions, at least, under which they were laid down. The physiography of the two areas during the time of deposition was so different as to constitute in itself a sufficient cause for the observed differences in the deposits. In the Northeastern Subprovince the accumulation took place in long parallel troughs which were largely if not completely isolated from each other and which received accretions of material derived from a closely adjacent source. Moreover, these troughs were in the line of a movement of earth folding and faulting which was at that time undergoing a constant 
access of intensity as the great Hercynian-Appalachian uplift developed from the east toward the west. The Southern Subprovince, on the other hand, was a basin of enormous size, with the bulk of its area far removed from the source of sedimentary material and subjected to vertical movements only of a relatively minor character. The folding of the eastern side of the basin took place at or after the close of the interval under consideration.

\section{THE NORTHEASTERN SUBPROVINCE.}

The Northeastern Subprovince includes portions of New Brunswick and Nova Scotia between the Bay of Fundy and Northumberland Strait, Prince Edward Island, and portions of the United States as far south as Massachusetts and Rhode Island. (Fig. I.)

(a) The Canadian Region.

A summary description of the portion of the subprovince which lies in Canada has been given by Young:1

"Along the banks of the East River, in the vicinity of New Glasgow, are exposures of a red, coarse conglomerate which has received the name New Glasgow conglomerate. This formation is the basal member of a very thick group of strata which, in a comparatively undisturbed condition, floor the country north and west of New Glasgow, outcropping along the Nova Scotian and New Brunswick shores of Northumberland Strait for a distance of about 80 miles (I $30 \mathrm{~km}$.), and underlying the whole of Prince Edward Island. What have been described as equivalent measures also occur in the western part of the Joggins section along the Bay of Fundy coast. The distribution of this group of strata is confined, so far as known, to the general region lying north of the Cobequid Hills, which stretch easterly from the Bay of Fundy to not far from New Glasgow, a distance of about 100 miles ( $160 \mathrm{~km}$.). In the portion of Nova Scotia north of the Cobequid Hills and the adjacent portion of New Brunswick, and in Prince Edward Island, this thick group of strata, of which the New Glasgow conglomerate in places forms the base, occurs in four distinct basins or areas. One, the Prince Edward Island area, occupies the whole of that island and is separated by the waters of Northumberland Strait from a second which lies on the mainland fronting Prince Edward Island. The second area stretches westerly to the head of the Bay of Fundy, lies partly in New Brunswick, partly in Nova Scotia. It is separated from the two remaining areas by an anticlinal axis of folding running eastward from the head of the Bay of Fundy to Northumberland Strait and along which are exposed Carboniferous strata of the age of the Productive Coal Measures and older. The third area fronts on the Bay of Fundy coast, forms the western portion of the famous Joggins section, and extends inland along the north flank of the Cobequid Hills. It is separated from the fourth area by axes of folding along which are exposed older Carboniferous rocks. The fourth area may be named the New Glasgow area. It stretches from New Glasgow westward along the north flank of the Cobequids and northward from the foot of the hills to Northumberland Strait.

"This widely extended and thick group of strata of which, in certain districts, the New Glasgow conglomerate forms the natural base, appears everywhere to

1 Young, G. A., Guide Book No. I, part II, Excursion in Eastern Quebec and the Maritime Provinces, issued by the Geological Survey, Ottawa, p. 229, I9I3. 
form a considerable series and, in places, even appears conformable with the Productive Coal Measures. The strata are largely sandstones, and because, in certain districts, varieties of a red colour predominate, the earliest geological observers assigned the group, in general, to the Triassic."

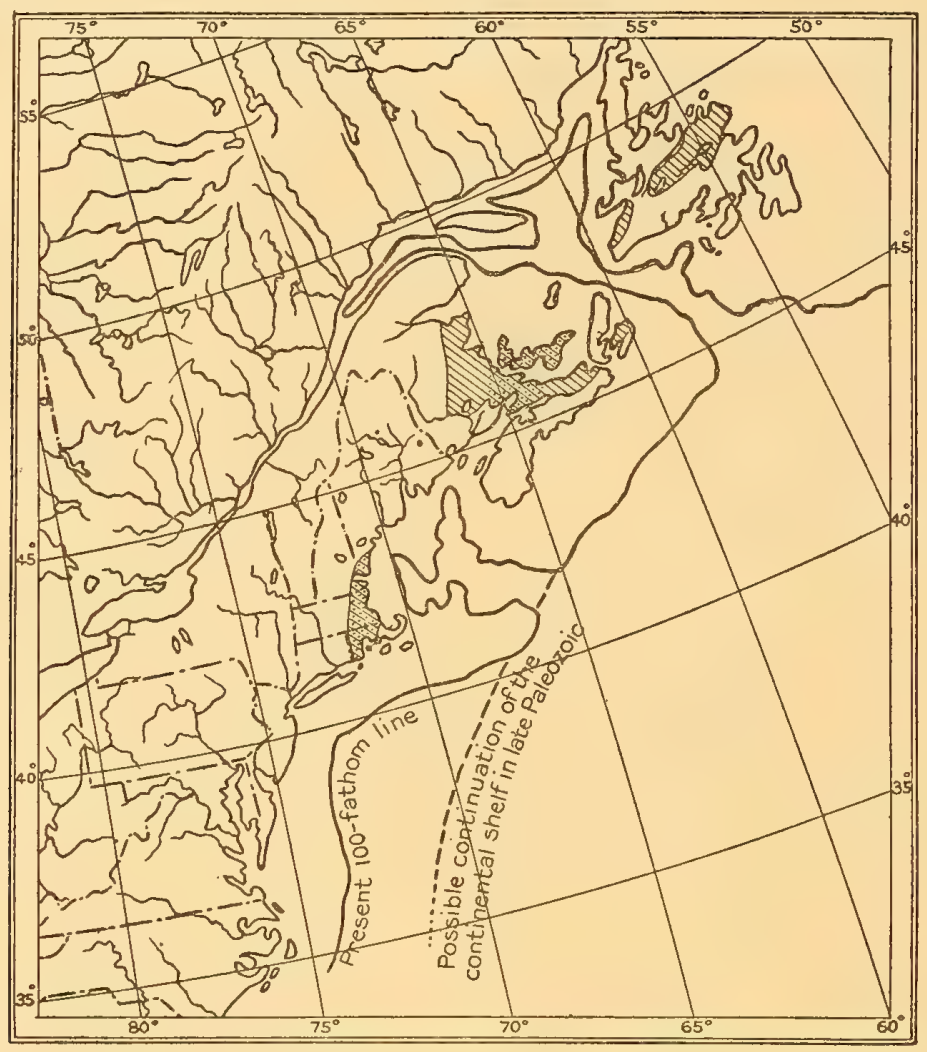

FIG. I.-Map of Northeastern Subprovince, showing the general lie of the late Paleozoic sedimentary deposits, the present outline of the continental shelf, and the possible outline in late Paleozoic. The lined areas are pre-Conemaugh (?) in age, the dotted areas are conglomerates and tillites of Conemaugh (?) or later.

The red rocks of Prince Edward Island and the adjacent portions of the mainland are now thought to be Permo-Carboniferous, without question. ${ }^{1}$ The most comprehensive description of the rocks of the island was given by Ells, ${ }^{2}$ a portion of which is quoted:

"In New Brunswick a narrow margin of the red sandstones, conglomerates, and associated shales of the upper series is found at several points along the shores of the Gulf of St. Lawrence, as far north as Shippegan Island. They are also well seen in the Tormentine Peninsula, where they pass downward into underlying gray sandstones, which here are supposed to represent the lowest portion of the Upper Carboniferous in this direction.

"Near Shediac and along the east coast of New Brunswick, these newer rocks rest upon gray sandstones and conglomerates which have been regarded as of millstone-grit age, and the productive Coal Measures have not as yet been recognized in this part of the province. While the gray beds of the two some-

${ }^{1}$ See Carnegie Inst. Wash. Pub. No. 207, p. 86, I 9I 5.

${ }^{2}$ Ells, R. W., Annual Report Canadian Geological Survey for 1902-3, vol. xv, p. 37 I. 
what widely separated divisions of the Carboniferous rocks present certain points of similarity, there are some features which render their separation possible. The sandstones of the upper series can be generally distinguished by being much softer and less coherent in character than the gray grits and conglomerates of the millstone-grit series.

"South of Baie Verte, this difference in character can be readily seen on the road leading across to Aulac. Thus, at the latter place, what is known as the Aulac Ridge rises near Aulac station on the Intercolonial Railway, and extends in a northeast direction, in the direction of Pointe de Bute and Tidnish. The rocks of this ridge are gray grits and quartz-pebble conglomerates, and have a distinct anticlinal structure.

"About 7 miles south of Baie Verte the millstone-grit outcrop terminates, but at Halls Hill, which is about 2 miles further north, a series of gray sandstones come in these rocks and have been cut down along the roadway. These belong to the newer series, and are soon overlaid by the soft red beds which are so conspicuous along the shores about Baie Verte, and thence east to Tidnish and on to Pugwash in Nova Scotia. In these red beds are bands of conglomerates in which the pebbles are largely made up of bright red shale, and thin bands of impure red limestone also occur at several points. The series as a whole is quite distinct from anything seen in the millstone-grit formation, and precisely resembles the rocks seen along portions of the shore of Prince Edward Island, from Cape Egmont to Wood Islands, as well as at many other points in that province. In New Brunswick they are also well exposed at Cape Tormentine, and along the shores of that peninsula at many places, while at Bayfield Corner and around Port Elgin they are underlaid by the grayer members of the upper series, which also show on the road between Shediac and Pointe du Chêne.

"These soft red rocks with occasional gray sandstones also appear along the north side of Nova Scotia in the counties of Cumberland, Colchester, and Pictou. Here for the most part they overlie directly, in so far as yet known, rocks of Lower Carboniferous age without the interposition of the millstone-grit or Productive Coal Measures. This contact appears to be of the nature of an overlap, since there is no indication of faults between them. It is probable, therefore, that in this northern portion the true Coal Measures have never been deposited along this side of Northumberland Strait.

"Further east the rocks of the newer series are exposed along the south side of Northumberland Strait to a point several miles east of Merigomish Island, or about 20 miles east of Pictou Harbour. At this place they rest upon sediments of Silurian and Cambro-Silurian age with which are associated granites and other igneous rocks. East of this the red rocks of the upper series are not exposed, either along the shores of Nova Scotia proper or on the island of Cape Breton. There would therefore appear to be a gap of considerable extent in the sequence of the geological formations in this part of the province.

"The structure of the rocks in Prince Edward Island indicates the presence of several lines of anticline which extend across Northumberland Strait from New Brunswick and Nova Scotia, and traverse the island in a general northeast direction. $* * *$

"Apparently the lowest rocks of the island series are dark-red sandstones with occasional beds of conglomerate in which pebbles are of soft, bright-red shale, with irregular beds of impure limestone, generally reddish in colour, but at several points a gray limestone also occurs. Pebble conglomerates are also 
seen at several places, as at North Cape, and on the shores of Mill River south of Alberton, the pebbles being of quartz, with, occasionally, pieces of hard metamorphic rocks. On the ridge about Io miles north of Wood Island, and on the road to Cardigan, a deposit of well-rounded pebbles is seen which have evidently been derived from beds of these conglomerates in the vicinity, and traces of which can be recognized in place.

"In character most of these red rocks are very similar to the beds seen in the sections along the Wallace and Waugh Rivers on the north side of the Cobequid Mountains in Nova Scotia. They are sometimes interstratified with beds of grayish sandstone which are usually thin and irregular, the gray colour apparently due to the elimination of the red colouring matter through the agency of plant stems which frequently occur in these lowest beds. This character is well seen at St. Peter Island, near the entrance to Charlottetown Harbour, as well as on Governor Island near by. Further east similar gray irregular beds are exposed in parts of the section at Gallas Point.

"On the west coast the nearest approach to this feature was observed on the shore at Campbelltown, where, underlying the great series of red shales and sandstones which form the cliff between Big Mimenegash and Wolf Cape, coarse reddish grits with grayish bands crop out at the base of the bluff. While these may not be quite so low in the series as some of the lowest beds of Gallas Point, they apparently indicate the lowest members of the series in this direction.

"These are overlaid by a considerable thickness, probably aggregating several thousands of feet, of soft red sandstones and shales, occasionally with bands of impure limestone, which are seen over the greater portion of the surface of the island. Much of the sandstone is a dark red or red-brown, and these pass up into red sandstones with shales which continue to the summit of the formation. Throughout this series there is no very great variety as regards the character of the rocks themselves, and all may be included in the same general group."

\section{(b) The Joggins Section.}

The important section at South Joggins, Nova Scotia, which faces west from the east shore of Chignecto Bay, has been repeatedly described. The latest statement by the Canadian geologists arranges the deposits as follows: ${ }^{1}$

Joggins series:

Late Pennsylvanian, Shulie formation;

Uplift and renewed erosion.

Middle Pennsylvanian, Joggins formation.

Early Pennsylvanian, Boss Point formation;

Disconformity.

Mississippian, Windsor formation;

Unconformity.

Cobequid series:

Pre-Mississippian.

${ }^{1}$ Guide Book No. r, part II, op. cit., p. 331, 19I3. 
It is only the upper two of these that need be considered as being within the time which would include the evolution of life at the close of the Paleozoic, but they are so clearly a continuum of the lower formations that a clear understanding of their significance demands a comprehension of the whole post-Mississippian-Joggins series. The Joggins section reveals the structure and deposits of the great Cumberland Basin, which extends from the Cobequid Hills on the south to the Minudie Anticlinorum on the north, and from Chignecto Bay to the Pictou Basin, with only minor interrupting folds.

The Mississippian, Windsor formation, consists of brick-red micaceous shale ( $\mathrm{I}, 024 \mathrm{feet}$ ), brick-red sandstone (209 feet), reddish sandstone (36 feet), greenish gray sandstone with comminuted plant remains (I 56 feet), and greenish gray lenses of concretionary limestone ( 88 feet); total I,693 feet.

Bell described the Windsor series as follows: ${ }^{1}$

"The fauna of the marine dolomitic limestones of the Windsor series at the base of the Joggins section indicates broad, clear-water, shallow, and warm seas. The succeeding and widely distributed deposits of gypsum were undoubtedly accumulated in shallow pans of the sea under a subarid and probably warm climate. The interbedded and overlying red shales and marls, barren of life, with an abundance of mud-cracks and ripple-marks, together with the general unleached condition expressed by the calcareous concretions and high alkali content, denote similar climatic conditions and a general retreat of the sea, followed by estuaries or wholly fresh-water deposition. The environmental conditions at this time appear to have been especially favourable for the formation of fresh-water subaqueous delta deposits, adjacent to very shallow seas, having had, it is thought, the forms of narrow but long basins, situated between mountain masses that had their origin in Devonian times.

"A complete withdrawal of the sea with consequent relative uplift of the land prevented further deposition in this area, but possibly an extensive period of erosion again brought about conditions favourable for fluvial deposition early in Pennsylvanian time - conditions which seemingly persisted to the beginning of the Permian time, as no truly marine or even estuarine fauna occurs in the Coal Measures of the Joggins area.

"The sediments of the millstone grit were laid down under more fluvial conditions, an environment attested by the presence of occasional coal seams, the increasing importance of dark to black shales, and the lighter coloured, though still imperfectly leached, sandstones. The interbedded red shales, barren of fossils, may represent the muds of fluvial flood flats, that subsequently were oxidized subaerially, while the irregular lenticular beds of concretionary limestone associated with the grey sandstones apparently add their evidence in favour of fluvial conditions and a warm climate.

"During the early Coal Measures the strata were laid down under more fluvial and swamp conditions, as expressed by the many thin coal seams, the predominant dark shales, and the more perfectly leached sandstones.

"In later Coal Measure time there is no evidence for a continued abundance of water, as the red-shale beds indicate seasons of aridity when all the carbon-

${ }^{1}$ Bell, W. G., Summary Report of the Geological Survey Branch of the Department of Mines for I9I I, Ottawa, p. 33I, I9I2. 
aceous elements were removed through oxidation under subaerial conditions. There was at this time a return to more arid conditions very similar to those of the millstone grit."

In a later paper Bell says: ${ }^{1}$

"The overlying Boss Point rocks are characterized by grey sandstones bearing abundant drift plant débris, which are like those of the higher beds, $i_{\text {. }} e_{\text {. }}$, of Pennsylvanian age, and by the occurrence of basal conglomerates and channels or lenticular beds of the peculiar limestone conglomerates, referred to above. These latter, in addition to the nodules of unfossiliferous limestone, contain pebbles of red sandstone and shale, all of which could have been derived from the underlying rocks of Windsor age, such as are still seen at Dorchester. . ..."

The Boss Point formation, which is, roughly at least, regarded as equivalent to the Pottsville, is stated to be-

"Made up of two quite distinct divisions, a lower predominantly red division and an upper prevailingly grey division. The lower red division consists of varying proportions of brick-red quartz conglomerates and red argillaceous sandstones and shales. The upper division is made up chiefly of greenish grey, yellow-weathering sandstone, interbedded with brick-red argillaceous shales, and with subordinate grey shales as well as thin seams of coal or carbonaceous shales, and thin beds of bituminous fossiliferous limestone. The typical sharp quartz sandstone of the upper division occurs at Boss Point, which name is accordingly chosen to designate the formation. In the Joggins section the conglomerates, aside from the limestone conglomerates already mentioned, are confined to basal members, but in New Brunswick they are much more prevalent."

According to this author, the Cobequid Mountains were subject to periodic uplifts in pre-Mississippian times and existed during the Mississippian as highlands or islands in the sea, being subject at this time to active erosion. At the close of Mississippian there were, apparently, warping movements parallel to the Appalachian axis somewhere south of the Cobequids which probably affected the height of this land and furnished the material for the Boss Point and Joggins formations.

Bell suggests that the change in sediments was in part due to a climatic change with increased humidity and more fluviatile conditions, with the accumulation of flood-plain and delta deposits.

The Joggins formation is separated from the Boss Point, according to Bell, by a disconformity. The red shale and sandstone (2,00o feet) earlier placed at the top of what is now called the Boss Point, is represented in the south limit of the anticline by 800 feet of coarse red conglomerate formed by material derived from the underlying Cobequid group, the red shales of the north limit being considered as an extension of this erosional and depositional interval. The various movements are discussed by Bell at some length in the publication cited, pages 367 and 368 .

${ }^{1}$ Bell, W. G., Summary Report of the Geological Survey Branch of the Department of Mines for I912, Ottawa, p. 366, I9I4. 
Following the red shales and sandstones which initiated the Joggins series is a considerable thickness of gray shales and an increase in the number of coal seams-

"A monotonous sequence is quite noticeable of zones of regularly, evenly bedded shales, thin sandstones, underclays, and coal, in alternation with massive, uneven beds of cross-bedded sandstone that characteristically channel into the underlying shale zones. . . Commonly in association with the coals are thin, shell-limestones which carry abundant Anthracomyas, Spirorbis, and leperditian ostracods, a fact which may be advanced as an argument in favor of temporary estuarine invasions, as the fauna is neither a distinctively marine nor a freshwater one." 1

It is possible that this same series was deposited south of the Cobequids, as at Parsboro on the Minas Basin, but the evidence is not conclusive.

The Shulie formation is composed largely of coarse grits and conglomerates, the material of which can be traced to the Cobequid region, with an increase of the size of the pebbles in that direction. Also there is an appreciable amount of material from the Joggins formation. The beds are markedly uneven; showing ripples, or crests and hollows, some of considerable size. Drift logs and other vegetation are not uncommon.

The characters cited above show that the Shulie formation, regarded by Ells as Permo-Carboniferous but placed by Bell in upper Pennsylvanian time, is almost entirely a subaerial deposit. Bell regards this as due to an elevation of the Cobequid region at the close of the deposition of the Joggins formation. It is probably in part the equivalent of the New Glasgow conglomerate.

The whole of the Cumberland Basin was the site of accumulation from the north, south, and west. In Boss Point time this was probably largely from the Caledonian upland of New Brunswick, with possibly some contribution from the Cobequids; in Joggins time it was largely from the Cobequids as at Styles Brook, I5 miles inland from the Joggins exposure, there are I,ooo feet of coarse conglomerate formed of pebbles directly traceable to the Cobequids. In Shulie time the amount of material from the south is increased in quantity. In conclusion it is stated-

"(I) That a large proportion of the finer material of the I3,600 feet (Logan's measurement) of Pennsylvanian beds of the Joggins section was probably derived from the pre-Carboniferous highlands to the southwest, west, and northwest; (2) that the excessive sedimentation in the Cumberland Basin was due to the establishment of a geosyncline in early Pennsylvanian time and to proximity to a Cobequid highland to the south; (3) that this Cobequid area was subject to periodic rejuvenations resulting in renewed activities of erosion; (4) that the derivation of these terrestrial sediments from the south, west, and northwest has resulted in an interfingering of synchronous lens-like deposits.

"Furthermore, the establishment of these successive Pennsylvanian periods of uplift, with their consequent effects on the sedimentation, explains what had 
previously been a mystery, viz, how a Cobequid upland of so narrow a breadth, even of Alpine height, could have furnished any important contribution to the thousands of feet of Carboniferous sediments." 1

The Joggins formation is stated by Moodie to be "very much the same age as the Linton beds and comes in near the base of the Allegheny River series." 2 This statement is made on the basis of the report by Bell, ${ }^{3}$ but this correlation can be regarded only as very provisional. It would appear more probable that it includes all the upper Pennsylvanian and that the Shulie is Permo-Carboniferous.

In I893, Fletcher, ${ }^{4}$ in describing the Permian of the Canadian region, concluded that the New Glasgow conglomerate was newer than the Coal Measures and separated from them (the millstone grit) by an unconformity. The dip of the lower beds is less steep than that of the upper and "gray sandstone with greenish and reddish tints, dipping $42^{\circ}$ to $51^{\circ}$, is overlain by thick beds of very coarse conglomerate which fills depressions in the lower beds." The upper conglomerate contains pebbles derived from the upper Pennsylvanian, millstone grit.

\section{(c) The New England Region.}

It is impossible to correlate directly the beds of the Northeastern Subprovince with those of the Southern, but enough has been written concerning the latter to show that the conditions which influenced the life of the close of the Paleozoic began as low at least as the middle of the Conemaugh, and it is possible to show that changes due to similar, if not synchronously identical, conditions occurred in New England and the Maritime Provinces of Canada. That the change in regularity, persistence, and color in the Pennsylvanian and West Virginia beds was due to an elevation to the east with an alteration in climate can hardly be denied, and the occurrence of conglomerates, glacial conglomerates, and irregular red beds to the north and east, with a traceable origin of the material to south and west, points to the same, or a similar, series of disturbances.

Emerson has recently given a summary of the geology of Massachusetts and Rhode Island, ${ }^{5}$ in which he states that the Carboniferous of the Boston basin consists of two series, the Cambridge slate and the Roxbury conglomerate.

The Cambridge slate lies unconformably upon the Roxbury conglomer-

${ }^{1}$ Bell, loc. cit., I9I2, p. 370, I9I4.

2 Moodie, R. L., The Coal Measures Amphibia of North America, Carnegie Inst. Wash. Pub. No. 238, p. I9, I9I6.

${ }^{3}$ Bell, W. G., Summary Report Canadian Geological Survey for 1912, p. 360, I914.

4 Fletcher, Hugh, Geological Surveys and Explorations in the Counties of Pictou and Colchester, Nova Scotia, Annual Report Geological Survey of Canada, new series, vol. 5, pp. I08-I4I, I893.

${ }^{5}$ Emerson, B. K., Geology of Massachusetts and Rhode Island, Bull. 597, U. S. Geological Survey, 1917. 
ate; both are folded, faulted, and in places considerably sheared. Metamorphism has gone so far that an imperfect cleavage is developed in the rocks everywhere in the basin.

In the southern part of the basin, at least, the Roxbury conglomerate is divisible into three members:

Squantum tillite.

Dorchester slate.

Brookline conglomerate.

The Brookline conglomerate lies upon the Mattapan volcanic complex, which is in places interstratified with the two lower members. It is from 500 to perhaps 2,00o feet thick and contains some layers or pockets of sandstone and a few thin lenses of slate.

The Dorchester slate consists of 3,500 feet of slate, shale, and argillite, with some interbedded sandstone and, at or near the top, 40 feet of greenish and yellowish quartzite. Here and there occur beds of reworked tuff. The formation is of a uniform character and appears to have been deposited in a body of fresh water, possibly a lake at the margin of the ice. According to Sayles, the Dorchester slate is composed of "red and purple slates, in part cross-bedded, interbedded with sandstone, and fine-pebble conglomerate. The slate is typically rather coarse-grained and consists largely of reworked volcanic sediments."

The Squantum tillite is made up of conglomerate and tillite with some interbedded sandstone and slate. It measures in different places from 50 to 600 feet in thickness, but the total thickness is unknown, as the base is exposed in only one locality. It may be that it is separated from the Dorchester slate below by an unconformity and it passes into the Cambridge slate above through roo feet of transition beds:

"A large part of the Squantum tillite appears to be of glacial conglomerate, containing striated and facetted pebbles as at Squantum and Hyde Park. *** He [Sayles] concludes that the ice probably came from the southeast and that there were at least three beds of till with two intercalated interglacial beds; a great piedmont glacier like the Malaspina Glacier must have deposited material such as is found."

A more detailed account of this important member was given by Sayles. ${ }^{1}$

"The Age of the Roxbury Series.

"The exact age of the tillite is uncertain. The lithological characters of the Roxbury series resemble closely those of the Carboniferous and Permian of the Narragansett and Norfolk Basins. The Roxbury series, which consist of the Roxbury conglomerate, the Squantum tillite, and the Cambridge slate, is newer than the Cambrian, as proved by pebbles in it of the granite which cuts the Cambrian. The Roxbury series lies, without much doubt, on the same granitic

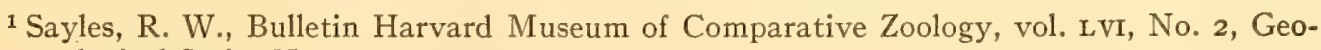
logical Series No. x, p. I64, I914. 
surface of erosion which underlies the Carboniferous in the Narragansett and Norfolk Basins.

"All that can be said at present is that the tillite is of Permo-Carboniferous age. The fact that the Permian glaciation was so widespread, and that new evidence of it is coming in so rapidly, makes it very probable that the tillite is of Permian age. No fossils of determinative value have been found, although Burr and Burke did find a fossil tree trunk in the Roxbury conglomerate proper. ${ }^{1}$

"History OF THE TILlite.

"A study of the sediments of the Boston Basin gives some idea of the physiography of the region, during late Carboniferous or Permian times. The area in which the sediments were deposited extended far and wide beyond the present limits of the deposits. That the area of deposition was low relatively to the surrounding country is certain, but that it was at sea-level is not so easily determined. Towards the close of deposition the land must have been subsiding as shown by the thick bed of slate over the tillite. In order for till to be preserved as a tillite, it must ordinarily be on a surface which is subsiding at or soon after the time of the retreat of the ice-sheet. $* * *$ Whether the slate above the tillite is of marine or fresh-water origin it is not possible at present to say. No clearly marine fossils have been found in it, and so far as this negative evidence goes it is more probably that this slate is of lacustrine origin. The absence of fossils, however, does not settle the question. Marine life in the Permian seas was scarce or wanting altogether in many places, and furthermore, fossils are not found in the marine clays of Pleistocene age outcrops. If volcanoes were situated then as now near the continental margins, the sea might not have been many miles away, for volcanic action was associated with the deposition of these beds, as shown by melaphyre flows in several places in the basin. According to Bailey Willis (Jour. Geol., vol. I7, 1909, pp. 403-405), land extended at least 100 miles in a southeasterly direction from Boston and probably much farther than this. That there was high land to the southeast appears probable also from a study of the tillite. The evidence so far points to a southeasterly origin for the ice which formed the tillite. $* * *$

"The Roxbury conglomerate proper at Atlantic exposes a thickness of about 520 feet. The lowest part shows rather small pebbles averaging about $I$ inch in diameter. Farther up the pebbles increase in size gradually, while in the transition beds below the tillite the pebbles are larger, averaging about 4 inches. It would seem very probable that this gradual increase in the size of the pebbles heralded the coming ice-sheet by wetter conditions or by a shorter distance from the source, as the ice drew nearer. If the larger size of the pebbles was due to more water and greater velocity, the pebbles should be as rounded as formerly, but if the approach of the ice was the cause of the size, the pebbles should be more angular as well as larger. The latter appears to be the case.

"Above the Roxbury a sandstone bed was formed, indicating slower stream action. A bed of conglomerate was then laid down, indicating swifter stream action. Another sandstone bed was then deposited. At this point a new phenomenon is met with. Above this last-mentioned sandstone comes a conglomeratic mass which differs from the Roxbury in having fragments and lenticular layers of slate. $* * *$. From a study of this bed I infer that the ice had come

1 Burr, H. T., and R. E. Burke, Proceedings Boston Soc. Nat. Hist., vol. 29, pp. 179-184, 1900. 
near when these fragments of clay were deposited. Just above this bed come about 47 feet of slate and sandstone layers with ripple-mark and some boulderets from 8 to ro inches in diameter. At this time the ice must have made a temporary halt or retreat. At least, deeper or slower water conditions prevailed."

Sayles continues his description, arguing for a series of advances and retreats of the ice.

Opposite page I7 of Bulletin 597, Emerson gives a table of the geological formations of Massachusetts and Rhode Island, from which the portion dealing with the upper Carboniferous and Permo-Carboniferous sedimentary rocks is quoted below:

\begin{tabular}{|c|c|c|c|c|}
\hline \multicolumn{2}{|c|}{ 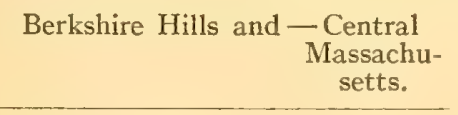 } & \multirow[t]{2}{*}{$\begin{array}{l}\text { Eastern Worcester } \\
\text { County and Merri- } \\
\text { mac Valley. }\end{array}$} & \multirow{2}{*}{$\begin{array}{l}\begin{array}{c}\text { Northwestern Massa- } \\
\text { chusetts, including } \\
\text { Boylston. }\end{array} \\
\begin{array}{l}\text { Cambridge slate. } \\
\text { Roxbury conglomer- } \\
\text { ate. } \\
\text { I. Squantum tillite } \\
\text { member. }\end{array}\end{array}$} & \multirow{2}{*}{$\begin{array}{l}\text { Southern Massa- } \\
\text { chusetts and Rhode } \\
\text { Island. } \\
\text { Dighton conglomer- } \\
\text { ate at north, Purga- } \\
\text { tory conglomerate } \\
\text { at south. }\end{array}$} \\
\hline & & & & \\
\hline $\begin{array}{l}\text { Amherst schist (east } \\
\text { side of Connecticut } \\
\text { Valley to Worcester } \\
\text { County). }\end{array}$ & $\begin{array}{l}\text { Brimfield } \\
\text { schist. }\end{array}$ & $\begin{array}{l}\text { Worcester, phyllite } \\
\text { (Pennsylvanian). } \\
\text { Dark phyllite. } \\
\text { Chiastolite schist. } \\
\text { Harvard conglomer- } \\
\text { ate lentil. } \\
\text { Boylston schist. } \\
\text { Brinfield schist. } \\
\text { Oxford schist. }\end{array}$ & $\begin{array}{l}\text { Unconformity. } \\
\text { (?) } \\
\text { 2. Dorchester slate } \\
\text { member. }\end{array}$ & $\begin{array}{l}\text { Rhode Island forma- } \\
\text { t i on (Pennsylvan- } \\
\text { ian). }\end{array}$ \\
\hline $\begin{array}{l}\text { Quabin quartzite. } \\
\text { Erving hornblende } \\
\text { schist. }\end{array}$ & $\begin{array}{l}\text { Paxton } \\
\text { quartz } \\
\text { schist. }\end{array}$ & $\begin{array}{l}\text { Oakdale quartzite. } \\
\text { Merrimac quartzite. }\end{array}$ & $\begin{array}{l}\text { 3. B rookline con- } \\
\text { glomerate member. }\end{array}$ & $\begin{array}{l}\text { Wamsutta formation. } \\
\text { Pondville and Belling- } \\
\text { ham conglomerates } \\
\text { (probably the same). }\end{array}$ \\
\hline
\end{tabular}

From Emerson we have the following comments on the more important of the various beds shown in the table: ${ }^{1}$

(Page 66.) The Harvard conglomerate lentil "may be equal in age to the Squantum."

(Page 72.). The eastern rocks of the Carboniferous area in Massachusetts are more calcareous than in the western, but "the whole series indicates, when compared with the more eastern beds described above, that the coal-forming conditions of the central and eastern parts of the State were disappearing and that deeper waters existed in the Connecticut region, deep enough for the formation of limestone and in some places near enough to the shore for the formation of conglomerate."

(Page 76.) Age of the Worcester, Oakdale and equivalent strata: "In the Narragansett Basin the coal-bearing Rhode Island formation overlies a series of coarse-grained strata, largely conglomeratic but including considerable sandstone and having at the base a conglomerate which rests unconformably on much older rocks. The lower formations contain fossil tree trunks, some of which

${ }^{1}$ Emerson, B. K., Geology of Massachusetts and Rhode Island, U. S. Geological Survey Bull. 597, 1917. 
belong to the genus Calamites, and the whole series is assigned with little doubt to the Carboniferous. The similar series in the Worcester district comprises the Oakdale quartzite below and the Worcester phyllite above. The Worcester phyllite is Carboniferous, for it contains Lepidodendron and several species of ferns at the Worcester 'coal mine.' Its substantial equivalence to the Rhode Island formation is indicated not only by its fossils but by beds of graphitic anthracite it includes. The lower parts of the series in the two areas also exhibit many points of resemblance, but in the Narragansett Basin the lower part is made up chiefly of conglomerate with subordinate sandstone and in the Worcester district almost wholly of sandstone with only a little conglomerate. It has generally been maintained that the conglomerates were derived from higher land lying to the east, and, on the assumption that most of southeastern New England was once covered by Carboniferous strata and that the rocks of the several basins were, therefore, originally continuous, this would explain the finer grain of the Oakdale quartzite lying to the west."

(Page I86.) "After the irruption of the Devonian (?) igneous rocks there was a long period of quiesence and erosion, during which the region was so greatly denuded that large areas of those rocks were exposed at the surface and deeply weathered. Early in Carboniferous time, as nearly as can be determined, another period of eruptive activity began and lasted, in one form or another, until after the close of the deposition of the Carboniferous strata."

(Page 5I.) "The coarse Dighton conglomerate, spread in great sheets over the thick coal-bearing shales of the Rhode Island formation in the Narragansett Basin, presents problems of its own. It is coarser toward the south and the pebbles of fossiliferous Upper Cambrian quartzite, not known in place, for which the rock is famous, are also larger and more abundant toward the south. On the other hand, pebbles composed of muscovite granite are larger and more abundant toward the north. To explain such conditions, Mansfield ${ }^{1}$ assumed the former existence of mountains of Alpine height on the southeast, which may have been the source of the floods and glaciers and have supplied the coarse material. Other mountains on the northwest of the Boston district were assumed as a source of the muscovite granite, as the nearest known granite of that sort lies in that direction. It is now known, however, that the muscovite granite northwest of Boston is younger than the Carboniferous sediments. The Dighton conglomerate finds its possible equivalent in the conglomerate at Harvard, in the Worcester district."

(Page 58.) "Correlation and age of the formations: No fossils, except at one locality a few obscure tree trunks, possibly Cordaites, have been found in the Roxbury conglomerate and none in the Cambridge slate. The age of the beds is assumed from what appear to be the most reasonable correlations with the formations of the Narragansett Basin, on the south. In both basins volcanic eruptions of similar lavas occurred during the early stages of deposition and presumably at about the same time. The Roxbury conglomerate is believed to be equivalent to the formations of the Narragansett Basin as a whole, and if so, it ranges in age from early Pennsylvanian possibly to Permian."

Emerson ${ }^{2}$ believes that the Carboniferous deposits were of continental formation and that the disconnected areas now forming the several basins

1 Mansfield, G. R., The Origin and Structure of the Roxbury Conglomerate, Harvard College Museum of Comparative Zoology Bulletin, vol. 49, pp. 99-271, 1906.

${ }^{2}$ Loc. cit., p. 52 . 
and troughs were originally continuous over the greater part of southeastern New England. The outward or northwestern border of the basal conglomerates runs through the Boston Basin, bends southward past Woonsocket, and thence runs near the west shore of Narragansett Bay. In the region north and west of this line the basal formation was fine sand, instead of gravel, and was overlain by fine mud, and the deposits of this kind were probably laid down in interfluvial plains that were afterward overspread by lagoons occupied by vegetation. The western margin of the great sheet of deposits was somewhere near the east side of the present Connecticut Valley.

A suggestion of the continuation of the Pennsylvanian deposits of the Boston Basin is found in New Hampshire and Maine. ${ }^{1}$ The Kittery quartzite is correlated by Katz with the Merrimac quartzite of eastern Worcester County, Massachusetts, and the Merrimac Valley, and the overlying Casco group of metamorphosed sediments is probably equivalent to the schists which lie above the Merrimac quartzite.

In Rhode Island Warren and Powers ${ }^{2}$ have distinguished two groups of Pennsylvanian rocks which they regard as of equal age, the Narragansett and the Bellingham. The Narragansett consists of four formations, the

Dighton group.

Pawtucket formation.

Wamsutta red beds.

Pondville arkose.

The Wamsutta red beds consist of red conglomerate shales and sandstones. The Pawtucket formation is "largely shales, sandstones, and some conglomerates." The age of the Narragansett series has been considered to be Pottsville-Allegheny from the paleobotanical evidence. Later discoveries by Haynes ${ }^{3}$ of bivalve crustacea, Estheria sp. and Leaia tricarinata M. and W., with Cordaites and Calamites in the Pawtucket suggest Conemaugh, but are not definitive.

The Bellingham group consists of lustrous green schists and sheared conglomerates. "The age of the Bellingham series is supposed to be the same as that of the Narragansett series. The character of the rock with its associated amygdaloids places it unquestionably in the Carboniferous."

The uncertainty of the stratigraphic position of the beds in Boston Basin and adjacent areas, as determined by accepted methods or correlation, is clearly recognized by the author; for that reason he suggests a test of the value of correlation by "environmental conditions."

${ }^{1}$ Katz, Frank J., Stratigraphy in Southwestern Maine and Southeastern New Hampshire, Professional Paper No. I08, U. S. Geological Survey, p. 165, 1917.

${ }^{2}$ Warren, Chas. H., and Sidney Powers, Geology of the Diamond Hill-Cumberland District in Rhode Island-Massachusetts, Bull. Geol. Soc. Amer., vol. 25, p. 447, I9I4.

${ }^{3}$ Haynes, W. P., Science, vol. 37, pp. I9I-I92, I913. 


\section{THE SOUTHERN SUBPROVINCE.}

As stated above, it is impossible to correlate at all exactly the deposits of the Northeastern Subprovince with those of the Southern Subprovince; indeed, it is very possible that these two subprovinces may bear very much the same relation to each other that exists between the Basin and Plains Provinces. The close similarity in the material and the sequence of deposits which exists between the Permo-Carboniferous beds in Prince Edward Island, Nova Scotia-New Brunswick, and Massachusetts-Rhode Island, the disposition of the beds in local basins between anticlinal elevations, the location to the east of masses of ancient igneous rock which form the northern extension of a part; at least, of Appalachia, all seem to indicate the original separation of these areas of deposition from the Southern Subprovince, either completely or in large part. The lie of the whole series of basins, ending with the Narragansett Basin, is such as to suggest a continuation southward upon the submerged and buried eastern portion of the ancient Appalachia continent. Such a possibility is entirely in consonance with the idea of gradual compression of the edges of the continents by suboceanic shove, as advocated by Ulrich. ${ }^{1}$ On the other hand, there is a total lack of paleontological evidence either for or against such a separation.

The recognition of the two areas as distinct provinces must wait for accumulated evidence, if it is ever to be done. There is much evidence, however, that both subprovinces were affected by a climatic change during the same interval of time or during approximately equivalent intervals.

The nature of the record of this change lends support to the suggestion that the basins of the Northeastern Subprovince are but a portion of a series which extended farther south, east of the present Piedmont Plateau and nearer to the area whose elevation initiated the climatic disturbance, for in these basins the red beds have as their basal members conglomerates and tillites, while the more abundant red shales and sandstones lie higher in the series and extend farther to the west. In West Virginia and Pennsylvania it is only the red shale and sandstone which appear in any quantityjust such a phase of deposition as one would expect if the elevated area were more distant (to the east) from the aggrading basins.

It is just this evidence of climatic change, though present in slightly different phases, which serves to bridge the gap in the correlation of the two subprovinces and also serves to mark the beginning of Permo-Carboniferous time, as it was not only a major change in itself, but points to a period of diastrophism, other evidence of which is largely hidden by younger deposits on the eastern side of Appalachia or did not develop until the close of the Permo-Carboniferous period.

1 Ulrich, E. O., Revision of the Paleozoic Systems, Bull. Geol. Soc. Amer., vol. 22, pp. 439442 , I9II. 
(a) Appearance of Red Beds in Pennsylvania and West Virginia.

The first appearance of red beds in the upper Paleozoic deposits of the Southern Subprovince is not the conventional line between the Pennsylvanian and the Permo-Carboniferous. It has for long been drawn at the top of the Waynesburg, the uppermost bed of the Monongahela series in Pennsylvania and West Virginia, but this location has been contested by $\mathrm{I}$. C. White, who claims that the alteration in the character of the sediments at a much lower stratigraphic level indicates a change in climatic and physiographic conditions which warrant the line being dropped to the level of the Saltsburg sandstone member of the Conemaugh in West Virginia, approximately the horizon of the Pittsburgh red shale in western Pennsylvania.

The original location of the line of division at the top of the Monongahela was determined by the evidence from invertebrate fossils, now somewhat less significant, owing to later discoveries, and from paleobotanical evidence, upon both of which David White still maintains the correctness of the original location.

[He] "is inclined to draw the Westphalien-Stephanien (Mid-Pennsylvanian) boundary provisionally at or close above the top of the Allegheny, the Mahoning sandstone being interpreted as showing the beginning of a more pronounced orogenic movement which seems gradually to have brought about the final exclusion of the sea." 1

In his latest discussion of this point, I. C. White ${ }^{2}$ says:

"In this connection it should be noted that the writer has for many years suggested and contended that the sudden introduction of red sediments into the Conemaugh series, after their total absence since the close of Mississippian time, when a long period of erosion supervened, was an event of unusual importance to geologic history. In fact, so distinctive as to warrant the last chapter of the Pennsylvanian being closed at that horizon, and the first chapter of the Permian or Permo-Carboniferous opened with the deposition of the Conemaugh red beds.

"The Permian fauna already described by Case from the horizon 34-40 feet below the Ames limestone at Pitcairn, Pennsylvania, proves incontestably that Permian vertebrate life had already arrived in the Appalachian field, just as it had in the western coal fields at the closing stage of the Illinois Coal Measures, and hence there can be no valid reason why representatives of Pareiasaurus may not have been among the arrivals that accompanied the new conditions producing the Pittsburgh red shales that succeeded the great white sandstone epoch which began with the Pottsville on top of the Mauch Chunk red beds, and closed with the deposition of the Mahoning, Buffalo, and Saltsburg sandstones making up the lower one-third of the Conemaugh series as now delimited. The marine fauna in the Ames limestone is largely composed of forms common to the Permian beds, as may be seen from the following list of species identified from West Virginia localities by Stevenson, Meek, Beede, Price, and others, as compiled by Wm. Armstrong Price:

${ }^{1}$ White, David, in Professional Paper No. 7I, U. S. Geological Survey, p. 437, I9I2.

${ }^{2}$ White, I. C., Notes on the Paleontology of Braxton and Clay Counties, West Virginia; Braxton and Clay County Report, Geological Survey of West Virginia, p. 822, I9I7. 
[Abbreviations: $x,=$ rare, at one or more localities; $c=$ common; $a=$ abundant; $a \mathrm{a}=$ very abundant.]

Endothyra $?$ sp..................... $x$

Serpula ? sp..........................

Vermes indet. (trails?) . . . . . . . . . . . . .

Crinoidea (plates and stems) $\ldots \ldots \ldots \ldots \ldots \ldots$ a

Rhombopora lepidodendroides?..............

Lingula umbonata . . ................. $x$

Orbiculoidea missouriensis................

Rhipidomella pecosi....................

Derbya crassa................... a

Derbya robusta ...................... $\mathrm{x}$

Chonetes granulifer.................. aа

Productus cora.

Productus semirecticulatus ...................

Productus pertenuis

Pustula symmetrica.

Pustula nebraskensis. . . . . . . . . . . . . .

Strophalosia $\mathrm{sp} . \ldots \ldots \ldots \ldots \ldots \ldots \ldots \ldots \ldots \ldots . . . \ldots \ldots$

Spirifer cameratus.

Composita subtilita..................

Composita sp.................... $x$

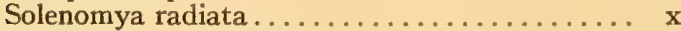

Solenomya soleniformis...................

Solenomya trapezoides?................ $\mathrm{x}$

Prothyris elegans ....................

Solenopsis solenoides.

Edmondia? scutum.

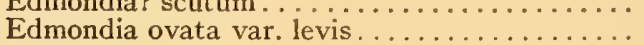

Edmondia gibbosa.

Edmondia sp.

Nucula anodontoides.

Nucula ventricosa.......

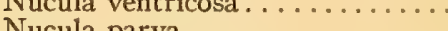

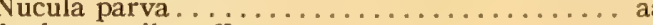

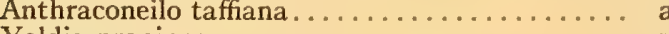

Yoldia propinqua.

Yoldia sp.

Leda bellistriata?

Leda meekana.

Parallelodon obsoletus

Aviculipinna americana

Aviculipinna nebraskensis

Pseudomonotis hawni.

Myalina subquadrata

Myalina perniformis.

Schizodus affinis?

Schizodus ulrichi?

Aviculipecten rectilaterarius. . . . . . . . . . . . .

Acanthopecten carboniferous.

Deltopecten occidentalis
Pectenoidea (fragments)...............

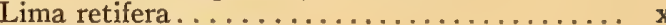

Allerisma terminale. ................ c

Pleurophorus oblongus? . . . . . . . . . . . . . . .

Pleurophorus occidentalis................ a

Pleurophorus $\mathrm{cf}$. obsoletus. .................

Pleurophorus? sp. . . . . . . . . . . . . . . . c

Pleurophorella geinitzi................

Astartella gurleyi....................

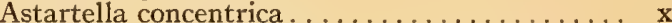

Pelecypoda indeterminata (several species).... $\mathrm{x}$

Bellerophon crassus var. wewokanus........ . . $\mathrm{x}$

Patellostium montfortianum............. aa

Patellostium kansasensis . ...............

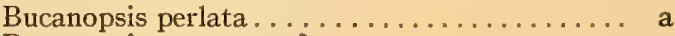

Bucanopsis stevensana?. . . . . . . . . . . . . . . .

Bucanopsis meekiana ...............

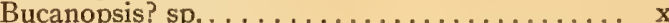

Euphemus carbonarius. . ............... aa

Pharkidonotus percarinatus................

Pharkidonotus percarinatus var. tricarinatus... a a

Worthenia cf. speciosa.................. a

Worthenia (Orestes) intertexta . . . . . . . . . . . a a

Phanerotrema grayvillense ............... a a

Schizostoma catilloides.................

Loxonema semicostatum................ x

Zygopleura plicata................... a

Zygopleura rugosa ..................

Zygopleura scitula ..................

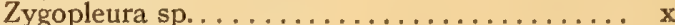

Soleniscus paludinæformis? . . . . . . . . . . . .

Bulimorpha chrysalis.................

Sphærodoma ? brevis . ..............

Sphærodoma ? primigenia ............. $\mathbf{x}$

Sphærodoma ? primigenia var. intermedia .....

Sphærodoma ? ventricosa .............. $x$

Aclisina swallowana....................

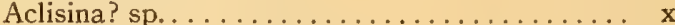

Orthonema quadricarinatum ............

Orthonema cf. subtæniatum ............

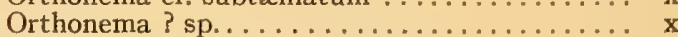

Minute, open-spiraled gastropod........... $x$

Gastropoda indeterminata (coils) ............

Orthoceras sp......................

Pseudorthoceras knoxense..............

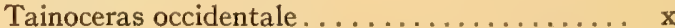

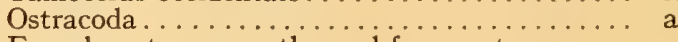

Eumalacostracean arthropod fragments....... . .

Boring organism ....................

"True, this list of Ames limestone fossils contains many that occur in the Pennsylvanian strata of this and other states, but that is no reason why they may not have continued to live on into Permian time.

"The Permian or Permo-Carboniferous age of these Conemaugh red beds is also confirmed by fossil plant remains recently discovered a short distance above the horizon of the Ames limestone, as related to me in a personal communication by Mr. David White, chief geologist of the United States Geological Survey, who states that a species of Callipteris, a genus diagnostic of the Permian beds, has recently been discovered in the upper half of the Conemaugh. In this connection it is pertinent to quote here the opinions of the writer concerning the age of these Conemaugh beds, as published in the reports of the West Virginia Geological Survey, beginning with his first description of the Conemaugh series as given in volume II, Coal Report, under date of June I5, I903, pages 225-227. 


\section{"The Conemaugh Series.}

"As now limited, it includes all of the strata from the floor of the Pittsburgh coal down to the top of the Upper Freeport bed, the whole having an average thickness of 600 feet, though it varies from 400 on the western margin of the Appalachian field in Ohio to 800 feet near Charleston, West Virginia.

"“'The series as thus limited above and below, consists of two widely different members, lithologically considered, the upper composed largely of soft, red, and marly shale, the lower of massive, pebbly sandstones. The difference in the rock type is so marked, and especially in the character of the topography made by each, that the First Geological Survey of Pennsylvania and Virginia placed them in two different series, the massive sandstones, at the base of the Conemaugh, being classed with the underlying Allegheny. That assignment, based primarily upon difference of rock type, was more philosophical than the present limitations, but the fact that no definite boundary (a sandstone always being subject to sudden and rapid change in both thickness and character) could be assigned to either the lower limits of the upper one, or the upper limits of the lower one, led Professors Stevenson, Lesley, and other Pennsylvania geologists to extend the limits of the "Lower Barren Measures" of Rogers down to the horizon of the Upper Freeport Coal, a well-marked and widely persistent stratum. This arrangement gives definiteness to classification, a great desideratum, but it has the fault of bringing together rocks of very different type, and hence, while apparently preferable to the old and indefinite dividing-line between the two series, is yet not altogether satisfactory. Hence, it is possible that a future and more detailed study of the series in West Virginia may reveal some more desirable dividing-plane between the Conemaugh series and the underlying Allegheny than the present one (Upper Freeport Coal), which will retain all of the desirable features of the Rogers classification and at the same time relieve it of indefiniteness.

" "Viewed from the standpoint of change in physical conditions, the proper place for such a dividing-plane between the Conemaugh series and the Allegheny beds would be the first general appearance of red rocks, near the horizon of the Bakerstown coal about Ioo feet under the Ames or crinoidal limestone horizon. That a great physical change took place soon after the deposition of the Mahoning sandstone rocks, the present basal members of the Conemaugh series, must be conceded, since no red beds whatever are found from the base of the Pottsville up to the top of the Allegheny, and none worth considering until after the epoch of the Upper Mahoning sandstone.

" The sudden appearance or disappearance of red sediments after their absence from a great thickness of strata is always accompanied by a great change in life forms, and the present one is no exception. In fact, the invasion of red sediments succeeding the Mahoning Sandstone epoch of the Conemaugh may well be considered as the "beginning of the end" of the true Coal Measures, both from a lithological as well as a biological standpoint, and hence it is possible that the best classification aside from the conveniences of the geologist, would leave the Mahoning sandstone in the Coal Measures and place the rest of the Conemaugh, as well as the Monongahela series above, in the Permo-Carboniferous. This reference is also confirmed by the character of the fauna and flora, both of which contain many forms that characterize the Permo-Carboniferous beds of Kansas and the West, as may be seen in the lists published on a subsequent page under the detailed description of the principal Conemaugh strata.

"As already stated, the two types of rock (hard and soft) included in this 
series give rise to two widely distinct varieties of both soil and topography. The uppermost 400 feet of soft beds, with their included thin limestones, and limy, red, yellow, and greenish shales, interstratified with two or three rather massive sandstones, give origin to a beautiful rolling topography often finely adapted to grazing and agriculture, especially where these beds cover the uplands not deeply trenched by draining streams. When the hills are high and steep, however, the red marly shales exhibit a great tendency to landslides, and hence, where such topography abounds, grazing rather than agriculture should be the chief occupation for these Conemaugh soils.

" A wide band of red marks the crop of this soft portion of the Conemaugh entirely across the State from the Pennsylvania line on the north to the Big Sandy River at the Kentucky boundary, 250 miles distant to the southwest.'

"Likewise in volume II (A), Supplementary Coal Report, West Virginia Geological Survey, published under date of September 15, 1908, on pages 622 to 624, inclusive, the writer used the following language in describing the Conemaugh series:

" "Sediments inherently red make their appearance for the first time in this series since the close of the Mississippian, with the top of the Mauch Chunk Red Shale. True, a pink or reddish color in the ferriferous clays, or shales of the upper portion of the Allegheny Series may sometimes be seen, as near Fort Gay, on the Big Sandy, and near Coal Grove, above Ironton, Ohio, but these apparent reds are from oxidation due to weathering, since these sediments were not red when deposited, and if a bore-hole could be sunk through them a few feet in from their crops no reds would appear. The genuine red beds of the Conemaugh were deposited as red muds from an old eroded land surface and are inherently red, whether at the surface or I,500 feet below the same, as is the Pittsburgh red shale in some portions of Wetzel, Monongalia, and other counties in the center of the Appalachian basin.

"'The general statements on pages 165,226 , and 227 , volume II, about the importance of the sudden appearance of red beds after their absence from the strata for a long period of time, and the possibility that the lowest Conemaugh reds might mark the dividing-line between important formations, such as the true Coal Measures and the Permo-Carboniferous, has received strong confirmation during the past year. Dr. Percy E. Raymond, of the Carnegie Museum, has discovered in these red shales, near Pittsburgh, at 35 feet below the Ames limestone, an interesting reptilian fauna which is closely related to Permian types. This fauna, including species of the genera Eryops, Desmatodon, and Naosaurus, allied closely to what have been regarded as Permian forms in Illinois and Texas, has been recently figured and described by Professor E. C. Case, in the Annals of the Carnegie Museum, volume IV, pages 234 to 24I, April I, I908. It is quite possible that a considerable break in the geologic record occurs at the close of the great sandstone epoch ending with the Saltsburg horizon just above Bakerstown coal where the great invasion of red beds begins. Although there is little or no unconformity in dip at this horizon, there may be a real unconformity of considerable extent, since the variation in the thickness of the sandstone deposits at the base of the Conemaugh is very great indeed.

"'In connection with the consideration of these Permian land reptiles discovered at Pitcairn, Pennsylvania, in the Pittsburgh red shales by Dr. Raymond, it should be mentioned that in I906 Mr. Ray V. Hennen, assistant geologist, discovered what appears to be a perfect tibia of a large reptile allied to Pareiasau- 
rus according to Osborn, but who after making a cross-section of the supposed bone, and finding no bony structure preserved, pronounced it a concretion, the most remarkable one he had every seen. Many geologists, and other vertebrate paleontologists who have seen the specimen, declare that its concretionary origin is not proven, and that it is most probably a sandstone cast, an actual fossil from which all bony structure and organic material have disappeared before lithification in its porous matrix, thus preserving only the outside surface and shape of the bone to perfection.

" Mr. Hennen found it lying loose upon the surface, near Salt Lick Bridge, Braxton County, a few feet above the horizon of the Ames limestone, where it had evidently weathered out of its original matrix in a greenish, micaceous, finegrained sandstone. Of course the testimony of this specimen will remain of doubtful value until its true nature is determined beyond question by the discovery of other concretions or fossils, as the case may be, in this same region. In this connection it should also be remembered that Scudder, in his Bulletin No. I24, U. S. Geological Survey, has described a fossil insect fauna from just above the Ames limestone near Steubenville, Ohio, in which he finds forms greatly resembling those in the lower Dyas or Permian of Weissig, Saxony, and hence it should not be surprising to find Permian reptilian forms in these Conemaugh red beds, which the writer has for several years insisted were more nearly related to the Permian than to the Carboniferous proper, and that the introduction of red sediments after such a long absence marked a change in physical and biological conditions sufficiently great to warrant a division of the geologic column at or near the horizon of the Ames limestone. It was formerly suggested that this division should come just above the Ames horizon, since its deposition marked the end of marine life in the Appalachian field, but the discoveries of Dr. Raymond of a Permian reptilian fauna at several feet below the Ames limestone would tend to show that this division-line should be drawn at the base of the Pittsburgh red shale, about Ioo feet below the Ames horizon, or the top of the Saltsburg sandstone.

"As these first red deposits were probably laid down upon an eroded land surface, the great irregularity of their thickness (which varies from Io to 200 feet) below the Ames limestone would be thus readily explained.'

"The peculiar type of fossil insects referred to above are described by the late Professor Samuel Scudder in Bulletin I24, U. S. Geological Survey, and on page I2 of the same he gives his reasons for regarding not only those found in the Cassville plant shale as above the horizon of the Pennsylvanian Coal Measures, but also those found near the Ames limestone near Steubenville, Ohio, in the following language:

" "The West Virginia locality is at Cassville, Monongalia County, not far from Morgantown, and the specimens were found in rocks lying above the Waynesburg coal, in what is termed by Professor I. C. White the Dunkard Creek series, and referred very positively by him and Professor William M. Fontaine to the Permian. The blattarian fauna as thus far determined is unquestionably younger than any known from the Pennsylvania or Illinois rocks, on which we have hitherto depended largely for our knowledge, and consists of a vast assemblage of forms, which will undoubtedly be increased by further search. They number 56 species, belonging to 5 genera, the bulk of them ( 36 species) to Etoblattina.

"The Ohio locality lies at the edge of the township of Richmond, on Willis Creek, in the near neighborhood of Steubenville, Jefferson County, and though far less extensive and less thoroughly worked than Cassville, has already yielded 
22 species belonging to 3 genera, of which the larger number ( $\mathrm{I} 7$ ) belong to Etoblattina and others to the genera represented at Cassville by more than a single species.

"It is a curious fact, to which I called partial attention when first describing some of them, that these species represent for the most part a distinct group of cockroaches of the genera Etoblattina and Gerablattina, characterized by great length and slenderness of the internomedian area, by a remarkable openness of the neuration in the middle of the tegmina, and by their frequently exceptional length and slenderness. They comprise, indeed, nearly 75 per cent of the species of these two genera at Richmond, and hardly occur elsewhere excepting at Cassville, where they compose about 25 per cent of the species of these two genera. The only occurrence of a similar form in Europe is Etoblattina elongata from the lower Dyas of Weissig, Saxony. The occurrence of this type of cockroaches is the characteristic feature of Richmond, and must place this fauna high in the series, as the stratigraphical evidence itself warrants. Its horizon, according to Mr. Huston, who alone has explored the location, is in the barren Coal Measures, a little above the Crinoidal limestone.

" It is remarkable that, notwithstanding the close relationship in general features of the two rich faunas of Cassville and Richmond, not a single species has been found common to the two. One species, indeed, I formerly regarded as found in both, but a closer study convinces me that there are in this case two nearly allied forms, and they are accordingly separated in this paper. Further than this, with one or two exceptions, no American species has been found in two different places, and without exception the American species are completely distinct from the European.'

"Hence we see that not only the reptilian life, but also the insect and plant life of the Conemaugh, supports the conclusion that the beginning of red sediments in the Conemaugh Series marks the dawn of Permian time, while there is nothing in the marine life of the epoch to contradict the same when properly interpreted. The presence of the peculiar type of Odontopteris, like Odontopteris (Lescurites) moorii, in the horizon 20 feet below the great Pittsburgh coal, near Wheeling, West Virginia, as identified by Fontaine, and also in the roof shales of the same near Greensburg, Pennsylvania, also confirms the very late age of the Monongahela series and would thus support the conclusion that the base of the Rothliegende or Dyas should be brought down from the top of the Waynesburg coal to near the base of the Conemaugh series or to the zone of the first appearance of red sediments in that series where there appears to be a true unconformity, or rather disconformity."

As early as 1880 the significance of the changes shown in the Monongahela deposits was recognized by Fontaine and White, ${ }^{1}$ who say in their report on the Permian flora:

"We may next inquire whether we have evidence of any considerable change which would suffice to produce an important effect, and alter the conditions which prevailed in the lower beds, which all recognize as of Carboniferous age. For this purpose we must turn to the general geology of the district. From this we find, after ascending above the Pittsburgh coal and its associated coals, the

${ }^{1}$ Fontaine, W. M., and I. C. White, The Permian or Upper Carboniferous Flora of West Virginia and Southwestern Pennsylvania, Second Geological Survey of Pennsylvania, Report of Progress PP, p. II7, I880. 
Redstone and Sewickley, two horizons which give evidence of extensive physical changes.

"The first of these horizons marks the general submergence which produced the important limestones and calcareous shales which occupy much of the interval between the Sewickley and the Waynesburg. We find no plants until we reach the roof shales of the last-named coal. These shales, as we see from our analysis of the table, contain nearly all the characteristic Carboniferous plants which pass into the Upper Barrens, mixed with a great number of new forms. The physical change here was not sufficient to entirely alter the flora.

"The second horizon of changing conditions is found in, and immediately above, the Waynesburg coal. In the rapid fluctuations in thickness of the clay parting of this coal we see the first indications of unquiet, and of the approach of that much greater disturbance which produced the important Waynesburg sandstone, which in its extent and character gives ample evidence of widespread change.

"The Waynesburg sandstone often rivals the great Conglomerate sandstone, which forms the base of the Productive Coal Measures in the amount of the pebbles it contains. It is often 75 feet thick, and in expanse is coextensive with the Upper Barrens. To form an idea, however, of the amount of change required to produce this great mass, we must not simply consider the character of the stratum per se, but must contrast it with the strata which immediately precede it. Leaving out of view the Waynesburg coal, all the rocks for a considerable distance under it are either limestones or fine-graned shales, which show that the deposition of sediment must have taken place under conditions of general quiet. The shale roof of the Waynesburg coal is not always present. We sometimes find the sandstone lying immediately on the coal, and even descending into it.

"When, then, in such localities we see the immense sandstone loaded with pebbles lying immediately upon the coal with its subjacent fine-grained beds, we are forcibly impressed with the magnitude of the change which has taken place. The character of the pebbles also is significant. They are not of sandstone, but of quartz, and hence must have been brought from remote localities.

"Let us now consider what is the evidence from the lithology of the strata of the Upper Barrens. Leaving out of consideration the finding of a conglomerate at the base of the series, a feature which it has in common with the Permian of Europe, we find in it a great deal of red shale, another feature of the Lower Permian of Europe. These red shales occur in beds 20 feet to 30 feet thick, sometimes commencing immediately above the Waynesburg sandstone. They are a pretty constant feature, and are often, as at Bellton, several hundred feet thick. These features, taken alone, are not entitled to much weight, except as showing conditions unfavorable for the formation of coal, as they are found in the barren portions of the Carboniferous formation proper. Besides these characteristics which mark the Lower Permian of Europe, the Upper Barrens have some in common with the Zechstein or Upper Permian, in the presence of a large amount of limestone.

"It is a significant feature that these limestones are devoid of marine fossils, showing that the sea had access at no time during their formation.

"The evidence from the total disappearance of coal beds in the higher portions of Upper Barrens, and from the extremely small amount of it found in the lower portions, is of more value, as indicating a great change from the conditions which prevailed during the Carboniferous proper. The beds of coal gradually dis- 
appear as we pass upwards, and with the exception of the Washington coal, are never more than I or 2 feet thick, while the uppermost 200 or 300 feet contain none at all. This diminution of the coal is accompanied with a great loss in the amount of plant life."

In the report by Fontaine and White ${ }^{1}$ on the Permian flora of Pennsylvania and West Virginia, there is a statement as to the red beds of the Upper Barren Measures (Dunkard):

"The upper half of the series is quite variable in the character of its strata. In some places we find it containing a great deal of massive sandstone, with drab, argillaceous beds, mainly incoherent shales. At other points, we find on the same horizon, several hundred feet of red shales, often mottled with green, buff, or yellow spots, and streaks. Toward the south, the red and variegated shales increase in thickness and descend lower in the series, sometimes even nearly to the horizon of the Waynesburg coal. The red shales are quite inconspicuous in Marshall County, and in the 600 feet of strata shown at Bellton we find about 400 feet of red shales, not in a single bed, but in several beds, from 40 to 60 feet thick, alternating with brown sandstones or drab-colored shales.

"The Waynesburg sandstone, the rock which forms the base of the series, is an important stratum, since its physical character denotes plainly a great change in the conditions which had prevailed for a long period previous to the time of its formation. As has been previously stated, these conditions were quiet subsidence, and deposition of fine shales, with much limestone. But in the sandstone now described we find many evidences of strong currents, which tore up the previously formed coal, and brought in a vast amount of coarse material. The approach of this unquiet condition of things is indicated in the structure of the Waynesburg coal itself."

The suggestion made and defended by I. C. White in the articles quoted above is strengthened by the discovery in these places of vertebrate fossils closely related to or suggesting the vertebrate fauna of the Texas and Oklahoma beds:

(I) The discovery of reptiles and amphibians in the Pittsburgh red shale by Raymond. ${ }^{2}$ (2) The discovery of Pareiasaurus (?) henneni White, 200 feet below the Pittsburgh coal and the base of the Monongahela series, in West Virginia. ${ }^{3}$ (3) The discovery of an Edaphosaurus spine in the Washington shales at the base of the Dunkard series, near Elba, Ohio. ${ }^{4}$ This discovery is from a higher horizon than the others and within the limits of the Permian as commonly recognized, but at its very base and from red beds similar in character to those carrying vertebrates in the middle of the

${ }^{1}$ Fontaine, W. M., and I. C. White, The Permian or Upper Carboniferous Flora of West Virginia and Southwestern Pennsylvania, Second Geological Survey of Pennsylvania, Report of Progress PP, p. 25, 1880.

${ }^{2}$ See Carnegie Inst. Wash. Pub. No. 207, p. 84, I915.

${ }^{3}$ Case, E. C., Notes on the Possible Evidence of a Pareiasaurus-like Reptile in the Conemaugh Series of West Virginia, Braxton and Clay County Report, Geological Survey of West Virginia, p. 817, I917.

${ }^{4}$ Stauffer, C. B., Divisions and Correlations of the Dunkard Series of Ohio, Bull. Geol. Soc. Amer., vol. 27, p. 88, 1915. 
Conemaugh series. (4) The reported occurrence of reptiles and amphibians from the Conemaugh of Ohio was based upon evidence that has not been verified and seems in itself insufficient. ${ }^{1}$

According to Scudder, the insects found at Steubenville, Ohio, have a very decided Permo-Carboniferous (Permian) aspect.

For the reasons advanced by $\mathrm{I}$. C. White and the contributory evidence of the vertebrate fauna, it seems necessary at the very least to examine carefully the possibility of faunal equivalence of the middle Conemaugh and the Permo-Carboniferous of Texas and Oklahoma. Stauffer, ${ }^{2}$ in the article cited above, states his belief in the equivalence of the Dunkard of Ohio and the Wichita formation of Texas.

"In view of this evidence of the vertebrate fossils, there can be no doubt that the lower portion of the Dunkard series is the equivalent of the lower Texas beds (Wichita) which overlies the Cisco and that in all probability both beds are Permian."

There is, however, much doubt that the occurrence of a single spine of Edaphosaurus is sufficient evidence upon which to base such a conclusion. A spine tentatively assigned by Case to the same genus was found by Raymond in the Pittsburgh red shale of middle Conemaugh time, which is much lower than the Texas vertebrate-bearing horizon. It seems to the author that in view of all facts it is far more probable that the presence of the vertebrate fauna of Permo-Carboniferous age depends rather upon climatic and physiographic conditions than upon any single time interval which can be identified stratigraphically in different parts of the continent. It is well known that in Pennsylvanian time the continent was gradually rising on the eastern side and that the conditions which influenced the deposition of late Pennsylvanian and Permo-Carboniferous beds progressed consistently to the west. This would produce a series of beds rising obliquely across the stratigraphic column toward the west and involve a correlation of conditions by the climatic and faunal elements in no sense synchronous in all places. This is a thesis which will be defended in another part of this work.

The stratigraphy of the upper Pennsylvanian and Permo-Carboniferous of Pennsylvania and West Virginia has been published in detail and need not be recapitulated. Only those formations which require discussion will be cited in the course of this summary. The probability of the equivalence of these beds in the Northeastern and Southern Subprovinces has already been stated (page 64). David White ${ }^{3}$ gives the following statement concerning the deposits of the Pennsylvanian in the Southern Subprovince:

"Character of the sediments.-The rock-forming materials are mainly terrigenous, brought down by rivers chiefly from eastward lands, which were probably

1 See Carnegie Inst. Wash. Pub. No. 207, p. 80, I9I 5.

2 Stauffer, C. R., Bull. Geol. Soc. Amer., vol. 27, p. 88, I9I 5.

${ }^{3}$ White, David, in Professional Paper No. 7 I, U. S. Geological Survey, p. 430, 19I2. 
the site of nearly continuous though variable epeirogenic action. Consequently the formations are in general thicker and more arenaceous toward the east side of the basin. The greatest thickening is toward the southeast, where at the edge of the Cretaceous overlap in Alabama, the Pottsville, or lower division, probably exceeds 7,500 feet. Marine or brackish-water faunas, extending over wide areas, occur at numerous stages except in the later Pennsylvanian, thus showing frequent accessibility to marine life, though the conditions of sedimentation in the Appalachian trough were generally less favorable for open-water marine mollusca than in the eastern interior arm. The subsidence kept, on the whole, relatively close pace with loading, so that, though the warping was unequal, there is slight evidence of the contemporaneous formation of new basins as the result of the orogenic changes."

The Allegheny series:1

"It embraces the softer sediments of more quiescent waters intervening between the arenaceous invading Pottsville and the Mahoning and other sandstone and shale members of the overlying Conemaugh formation ***. As compared with the Pottsville the members of the Allegheny are relatively regular and continuous, and the occurrence in them of marine mollusca is comparatively common.".

The main strata of the Allegheny beds, according to Orton and I. C. White, can be traced across Ohio from Columbiana County to Kentucky, 250 miles, beyond the Pennsylvania line. Considering with this the extent and persistence of the Allegheny series in Pennsylvania and West Virginia, there is, apparently, a Pennsylvanian base for a Permo-Carboniferous series, quite similar to the condition which prevails in the western provinces, but at a considerably lower stratigraphic level.

The Conemaugh, in strong contrast to the Allegheny, has an irregularity in the beds far exceeding even that of the Pottsville. The different layers vary in thickness and in many places some are absent, but there are some which are very persistent. The limits of the Conemaugh have been arbitrarily fixed, mostly for convenience in mapping; there is the same shading from persistent dominantly calcareous beds below into more shaly and irregular beds above, with a rapid appearance of red beds such as occurs in the Plains Province and parts of the Basin Province. The Monongahela is, like the Conemaugh, variable in character, but contains much limestone and coal. The bulk of the red and green sandstone and shale is in the southern portion of the Monongahela; towards the north the deposits are more normal in color.

The Dunkard in its maximum thickness consists of 16 to 18 members, being alternations of limestone, coal, and sandstone. According to Stevenson, ${ }^{2}$ the Dunkard is smaller in extent than the Monongahela and confined to a limited area in the adjoining portions of Pennsylvania, Ohio, and West

1 White, David., loc. cit., p. 434.

${ }^{2}$ Stevenson, J. J., Carboniferous of the Appalachian Basin, Bull. Geol. Soc. Amer., vol. I8, p. 160,1907 . 
Virginia. The area covered was originally much larger, as outliers are found in Pennsylvania, West Virginia, and Maryland; all evidence of the original extent to the east has been removed by erosion.

David White ${ }^{1}$ is quoted by Stevenson to the following effect from a revision of the original work by $\mathrm{I}$. C. White and Fontaine on the flora of the Dunkard:

The fauna of the Dunkard is placed in 5 categories:

a. Those characteristic of the Rothliegende or higher..................... I2 species.

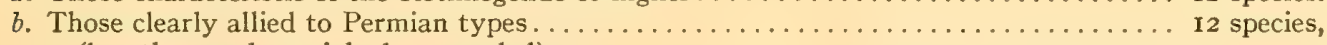
(but the number might be extended).

c. Those whose habit and facies suggest a late date, all new and unknown elsewhere, suggest later date than the Coal Measures.............................. I4 species.

d. Those of Mesozoic aspect, important as nearest relatives are Mesozoic........... 9 species.

$e$. Coal Measure types, widespread forms................................. 29 species.

David White considers the Dunkard flora as transitional between the Permian and the Coal Measures, the beginning of the former being determined by the first appearance of the Rothliegende forms. He considers the beds below the lower Washington limestone as transitional beds; above this the flora contains an increasing number of Rothliegende forms. The flora of the upper Dunkard is to be compared with that from Stockheim and Cusel in Germany and Brives in France.

The persistence of a large number of Coal Measure forms and the wellknown and repeated occurrence of more rapid evolution in floral elements than in the faunal elements in geological time makes this certainly as good an argument for Permo-Carboniferous age as for Permian and in no wise militates against drawing the Permo-Carboniferous line at a lower level. (See also I. C. White's note of the discovery of Callipteris in the upper half of the Conemaugh, as reported by David White, cited on page 66.)

Stevenson continues:"

"None of the characteristic coniferous genera Ullmania, Tylodendron, Walchia, occurs in Dunkard beds, though all are in Prince Edward Island and Walchia is reported from Texas [and New Mexico-Case]; and similarly many genera of ferns characterizing the Rothliegende of Europe seem to be wholly unrepresented. ***

"The general physical conditions during Allegheny and Conemaugh were practically the same; for, while the basin was contracting, there was no material variation in character of the movements; but with the beginning of Monongahela the area of greatest subsidence was shifted a hundred miles and the new condition remained unaltered throughout the Monongahela and Washington, which in this respect are one as the Allegheny and Conemaugh are one. A notable change occurred in the Washington, and Mr. White has shown that the strongly marked lower Rothliegende flora makes its appearance near the bottom of the Greene formation."

In these remarks concerning the similarity of the Allegheny and Conemaugh, Stevenson is not in agreement with other writers, who see a decided difference between the two series.

\footnotetext{
${ }^{1}$ White, David, Permian Elements in the Dunkard Flora, Bull. Geol. Soc. Amer., Abstract, vol. XIV, pp. 538-542, I903.

2 Loc. cit., p. 173.
} 
(b) The Western Part of the Southern Subprovince.

The upper Pennsylvanian and Permo-Carboniferous of Pennsylvania and West Virginia is continued almost without break into Ohio and Kentucky. A detailed summary of the Conemaugh formations in Ohio was quoted from Condit in Publication No. 207 of the Carnegie Institution, pages $8 \mathrm{I}$ to 84 , and need not be repeated here. It is noted, page 83 of that publication, that it is evident from Condit's description that conditions in Ohio during Conemaugh time were in many regards very similar to those obtaining (at a later date?) in the Plains Province. Condit says: ${ }^{1}$

"The Permian of the West, characterized by bright colors and beds of gypsum, is a still more striking illustration of this kind [beds deposited as deltas in a semiarid, climate]. While evidence of such pronounced aridity is lacking in the Permian (Dunkard) beds of the Appalachian basin, still it is evident that conditions were somewhat similar. It is believed that the appearance of the red color in the Conemaugh marks the beginning of the Permian. In southern Ohio, where the Monongahela coals and limestones are scantily developed, the red beds are practically continuous from the Conemaugh through the Monongahela, uniting with those of the Dunkard."

The Dunkard formation in Ohio according to Stauffer ${ }^{2}$ is represented by only the thin edge left by the erosion, of the much more extensive bed which lies to the east.

"At the northern end of the Ohio portion of the Dunkard basin there is no appreciable break between the Monongahela and the overlying Dunkard series. From the stratigraphic relations the basal plant beds (Cassville) ought therefore to continue the same flora that flourished during the formation of the preceding Waynesburg coal bed, but apparently such is not the case. Over the southern half of the basin, however, the Waynesburg sandstone usually rests directly on the Monongahela with marked unconformity, the Cassville, the Waynesburg coal, and a portion of the underlying shales usually being absent. Unconformities in a series of rocks, such as the Dunkard, probably do not have any very great significance; in fact, they occur at several horizons within the series; but the development of the coarse, massive Waynesburg sandstone, often a true conglomerate, over much of the unconformity between Monongahela and Dunkard, may be indicative of changed conditions.

"*** This division of the Dunkard into two formations is very arbitrary, as the stratigraphical or even the lithological break at the horizon used is not pronounced. It does, however, mark the highest level at which marine or brackishwater fossils were found and probably represents the approximate close of the oscillations between land and marine conditions, and introduces the purely land and fresh-water deposits in the Dunkard basin. ***

"A large part of the Dunkard of Ohio is to be classed as 'red beds,' although the Monongahela series and even the Conemaugh are not without their red shales,

\footnotetext{
${ }^{1}$ Condit, D. D., The Conemaugh Formation in Ohio, Bulletin Ohio Geological Survey, vol. I7, p. 259, I912.

${ }^{2}$ Stauffer, C. R., Divisions and Correlations of the Dunkard Series in Ohio, Bull. Geol. Soc. Amer., vol. 27, p. 86, I9I 5 .
} 
which in the Monongahela are often so like those of the Dunkard as to make them easily confused if it were not for other well-defined strata associated therewith. There are but few really red sandstones, and those are usually only coated red on the outside or weathered surface in the Ohio Dunkard. The red is thus almost confined to the shales. In the northern part of the Dunkard covered area the red beds are to be found chiefly in the Greene formation, but to the southward most of the shale in the whole series is red. In the main, these shales, sandstones, limestones, and beds of coal represent land and swamp or fresh-water deposits, but the presence of gypsum in certain of the shales and sandstones, and again marine or brackish-water fossils in other beds, indicates that these conditions at times gave place to others of a very different character.

"The Dunkard series as a whole is not very fossiliferous; in fact, it is almost as barren of the identifiable traces of life as it is of the workable coal seams, which originally suggested the term 'Upper Barren Measures' for this deposit. In addition to the occasional plant fragment that may be found in almost any part of the series, there are certain rather well defined horizons in the Ohio Dunkard which have yielded important fossils. Plants are, of course, of first importance. Their remains are occasionally to be found in the roof shales of any of the coal seams or even in beds of argillaceous shale and sandstone. Almost any outcrop of limestone may be found to contain small fresh-water gastropods and ostracods. The middle and upper Washington limestones of ten contain fish plates and teeth, some of which are referable to sharks, and are therefore probably marine. A Lingula occurs in the shales associated with the Washington coal. The lowest shales of the series are sometimes a black carbonaceous mass associated with a hard limestone, and these beds contain scales, teeth, and coprolites, all of which are probably fish remains. The most important find of the whole fossil collection, however, was made in the red shales of the Washington formation in the vicinity of Elba and Marietta. At the former of these places, near the base of the Dunkard, amphibian coprolites were found in relative abundance. These are remarkably similar to those found in the Permian of the Western States. At the latter place, during the past summer, fragments of a neural spine of Edaphosaurus were found in the sandstones associated with the red shales just above the Lower Marietta sandstone. The remains of this reptile have never before been found in the United States outside of Oklahoma, Texas, and New Mexico. ${ }^{1}$ The importance of this find must be very evident, since it agrees with the earlier conclusions drawn from identifications of the Dunkard flora and proves the age of the Dunkard to be identical with the Permian or Permo-Carboniferous of Texas. After having seen the whole vertebrate collection, Dr. S. W. Williston says that 'of the fishes I recognize teeth like those of Diplodus from the Texas Permian, but this type runs through the Pennsylvanian and is not characteristic. The Elasmobranch spine is unlike any that I have seen in Texas. The coprolites can not be distinguished from those commonly found in Texas and New Mexico. * * * The Edaphosaurus spine is unquestionable, small as it is. The range of the family in Texas is both Wichita and Clear Fork. It occurs in New Mexico in the El Cobre beds, which the accumulated evidence now places as the equivalent of the lower Texas beds (Wichita). *** In Europe Edaphosaurus occurs in the uppermost Carboniferous of Kuonova and the Rothliegende of Saxony.' (Personal letter.)"

${ }^{1}$ Dr. Stauffer here overlooks the discoveries made by Raymond in the Pittsburgh red shale of western Pennsylvania. 
As stated above, Stauffer believes that this discovery proves the equivalence of the Dunkard with the Permo-Carboniferous beds of Texas and Oklahoma.

The Monongahela series is but slightly more extensive in Ohio than the Dunkard, having lost material from the western edge by erosion.

"The character of the rocks interstratified with the coal beds ${ }^{1}$ changes greatly in passing from the Monongahela River southward to the Great Kanawha. At the northern end of the basin *** limestone forms about one-half of the rock material, and the same is true on the western side $* * *$. Red shale is unknown in the series at the north, but in passing southward from Harrison and Lewis Counties [West Virginia] the limestones practically disappear, and with them all the coals but the Pittsburgh. With their disappearance red shales come in and apparently replace the limestones, so that on the Great Kanawha nearly one-fourth of the rock material in this series is red shale, while the thickness is reduced to 270 [from $4 \mathrm{I} 3$ ] feet."

The Conemaugh extends beyond the edge of the Monongahela in Ohio and reaches into eastern Kentucky.

"This series, ${ }^{2}$ as thus limited above and below by important coal beds, consists of two very different members - an upper one composed largely of shales, therefore soft, easily eroded, and always making rounded hills and rolling topography, the other, or lower, composed largely of massive sandstones which resist erosion. $* * *$

"The upper portion always contains a large percentage of red and marly shales, which make a broad band of red soil from Pennsylvania through central West Virginia, to and beyond the Kentucky line on the one hand, and thence circling around through eastern Kentucky and southern Ohio, back to Pennsylvania again on the other. $* * *$

"The coal beds of this series are, with one or two exceptions, noted for their variableness and uncertainty. They may be in fair development on one farm and absent entirely on the adjoining one. They are also usually rich in ash and poor in carbon, and although they are patchy in their distribution, yet the main beds appear to maintain the same horizon in the stratigraphy, and can thus be identified with reasonable certainty over wide areas. The sandstones found within the limits of this group are of more economic importance than the coal beds, since the former nearly always furnish most excellent building stones. $* * *$

"The limestones of this series, like the coals, are generally thin and impure, so they are of more importance in determining the stratigraphy than for economic purposes."

The deposits of the Western Interior Coal Field are here considered as a part of the Eastern Province, but it is probable that the major portion is below the middle Pennsylvanian and so throws little direct light upon the conditions during late Paleozoic time. Upon the usual basis of correlation by fossils there is no suggestion that any layers below Coal 6 are higher than the base of the Conemaugh. The uppermost division of the series, Coal 6 (Grape Creek, Herrin) and above, may be of Conemaugh age.

1 White, I. C., Stratigraphy of the Bituminous Field Coal of Pennsylvania, Ohio, and West Virginia, Bull. 65, U. S. Geological Survey, p. 43, I891.

${ }^{2}$ White, I. C., loc. cit., p. 7 I. 
"We' may safely conclude that the horizon of the Grape Creek flora is not lower than the Freeport group on the one hand, while granting that it may on the other hand, eventually be found to be at a somewhat higher stage in the as yet paleobotanically unknown Conemaugh series."

White also makes the statement that the closest affinities with the Grape Creek flora will probably be found in the lower portion of the Missourian or the uppermost Des Moines:

"The composition of the Grape Creek flora indicates a stage in the lower Stephanian of the Old World. The latter division of the European Coal Measures appears, in the present stage of our knowledge of the fossil floras, to correspond to the Monongahela and Conemaugh series, together, perhaps, with the Freeport group of the Allegheny series of the eastern United States, and to the Missourian, with the upper portion of the Des Moines, of the Interior Basin."

In Bulletin I $_{5}$ of Illinois Coal Mine Investigations, $\mathrm{Cady}^{2}$ states that David White concludes from floral evidence that Coal No. 6 (Grape Creek, Herrin) "may be of Freeport age, possibly as high in the stratigraphic column as the upper Freeport coal, which is the uppermost layer of the Allegheny formation in the Appalachian region."

In the scheme adopted by the Illinois geologists all the Pennsylvanian deposits above Coal No. 6 are included in the McLeansboro formation. The dividing-line between this and the underlying Carbondale formation is not readily distinguished in many places, but in the light of fossil and stratigraphic evidence it seems safe to consider the McLeansboro as equivalent to the Conemaugh and higher series in Pennsylvania.

It is to be noted, however, that little or no red shales or sandstones appear in the McLeansboro formation. If this formation is equivalent to the Conemaugh and higher, then the necessary conditions for the formation of red beds were either never present in Illinois, or, what is more probable, the conditions necessary for the formation of red sediments had not reached Illinois within the time of deposition of any portion of the McLeansboro now preserved.

In Bulletin 15 of the Illinois Coal Mining Investigations cited above, Cady gives an account of the McLeansboro formation, from which the following is abstracted:

"The formation consists of several distinctive beds of shale and a minor amount of sandstone, limestone, and coal. Although several of the coals above No. 6 are persistent, none have been found sufficiently thick to be of commercial value. They are significant only as correlation horizons. In its barrenness of productive coals and in general age, the McLeansboro is similar to the Conemaugh formation of Pennsylvania."

${ }^{1}$ White, David, in the Danville Folio, No. 67, U. S. Geological Survey, I90o.

${ }^{2}$ Cady, G. H., Illinois Coal Mine Investigations, Bull. I5, Coal Resources of District VI, p. 26, 1916. 
There follows in plate I I, opposite page 26 , a series of graphic representations of drill-holes in the McLeansboro in district vi and Shelby County and a detailed record of a single hole, which show the absence of red shale and sandstone and prevalence of black, blue, and gray colors.

In district VI the following are the most well-marked of the horizons above Coal 6.

7. New Haven limestone

6. Shoal Creek limestone.

5. Carlinsville limestone.

4. Coal No. 8, 8 inches to 2 feet.

3. A bed of pink, red, or variegated shale, variable in thickness, seldom exceeding 15 feet (local).

2. Coal No. 7 , generally only a few inches thick.

I. A hard limestone averaging 7 feet in thickness, overlying and slightly above Coal No. 6.

Most of these horizons can be recognized in district vi, but not all, and there are some in district vI not occurring in VII. Layer 3 is not present in district vi. The limestone directly above Coal No. 6 bears marine invertebrates.

"Of the remaining 400 feet, more or less, of the McLeansboro formation (above the New Haven limestone) known from drilling in this district, only the lower 300 feet or so has been explored by the drill a sufficient number of times to warrant generalizations in regard to it. *** Most of the material above the New Haven limestone is shale and sandstone with no characteristic beds."

One bed of coal less than 5 feet thick and lying about 550 feet above Coal No. 6 is mentioned in a number of well records.

The nature of the beds in the McLeansboro formation appears to the author a confirmation of his position long held, that the reptilian and amphibian remains found near Danville, Vermillion County, Illinois, occur in deposits of a much later date than the beds with which they are associated.

The McLeansboro formation of Illinois is equaled in Indiana by a few hundred feet of shale and limestone with a few thin coal beds. Ashley ${ }^{1}$ has divided the upper Pennsylvanian of Indiana, as shown in the correlation table, opposite page 48.

On page 59 of Ashley's report cited above, it is stated that in a general way the coals and rocks above coal vir in Indiana belong to the Conemaugh and higher formations of Pennsylvania. With the exception of limestones above coal vil there are only shales and sandstone, with clays just above the coals:

"There is no dominant sandstone except one above what may be called coal IX, which is believed to be the sandstone outcropping at the top of the bluff at Merom, and from this exposure has been called the Merom sandstone.

1 Ashley, G. H., Supplementary Report on the Coal Deposits of Indiana, 33d Annual Report Department of Geology and Natural Resources of Indiana, I908. 
"A short distance below the Merom sandstone is commonly found a limestone which is thought to correlate with what has been called the Somerville limestone of southern Illinois and southwestern Kentucky, though that correlation is rather conjectural than demonstrated." (Ashley's report, p. 6i.)

The character and position of the Merom sandstone in Indiana has been described in Publication 207 of the Carnegie Institution, pages 78 to 80 . The equivalents in Kentucky as taken from Miller ${ }^{1}$ are shown in the correlation table.

The red and purple shale and sandstone mentioned by Miller is not described in any of the reports of the Kentucky Geological Survey dealing: with the western field. The only red deposits in western coal field of Kentucky occur in connection with the Madisonville limestone in the Earlington quadrangle, which lies in western Hopkins and southern Webster Counties. The Madisonville limestone here lies about 185 feet above the Nebo coal, which is generally considered to be the equivalent of coal I4.

"The Madisonville limestone ${ }^{2}$ contains two to four divisions, ranging through a maximum interval of 40 feet. $* * *$ It is hard, brittle, very resistant to weathering agents, weathers to a gray color, and carries an abundance of marine fossils. Between the beds of limestone are intervals of red clay and shale * **."

This horizon is well above the red beds of the eastern coal field of Kentucky which are of Conemaugh age.

\section{(c) Conditions in Iowa.}

West from Illinois there is a second break in the outcrop of the upper Paleozoic caused by the uplift and disturbance of Ozarkia in southern Missouri. The connection, if any existed between the upper Pennsylvanian beds on either side of this break, was probably through Iowa.

The Missourian, upper Paleozoic of Iowa, is a direct continuation of the same formation in Missouri and Kansas and does not differ materially from them. There is no indication of red beds or red-bed conditions in this part of the formation.

In Webster County a small area of red sandstone and shale accompanied by gypsum lies unconformably upon the Des Moines formation and the St. Louis limestone where the Des Moines has been eroded away. "An erosion interval of considerable length thus separates the period of their deposition from the Des Moines epoch." 3

The red rocks and gypsum of this limited area have been tentatively referred to the Permian upon stratigraphic grounds by Wilder, ${ }^{4}$ but as the

${ }^{1}$ Miller, Arthur M., Table of Geological Formations for Kentucky, Department of Geology University of Kentucky, I9I7.

${ }^{2}$ Kentucky Geological Survey, series IV, vol. II, pt. I, p. I32, I9I4.

${ }^{3}$ Norton, W. H., and others, Underground Water Resources of Iowa, Water Supply Paper No. 293, U. S. Geological Survey, p. 86, I9I2.

${ }^{4}$ Wilder, F. A., Geology of Webster County, Geological Survey of Iowa, vol. 12, p. 63, I902. 
author has shown in Publication 207 of the Carnegie Institution, page 77, the red deposits are not to be directly correlated with the red beds of Texas and Oklahoma, though they were undoubtedly formed very near the top of the Pennsylvanian (Missourian) and may even be Permo-Carboniferous.

\section{(d) Conditions in Missouri.}

The condition of the area between the extreme western edge of the Eastern Province (Illinois and Kentucky) and the eastern edge of the Plains Province in Missouri and Kansas during Pennsylvanian time has been well described by Hinds and Green. ${ }^{1}$

"At the beginning of the Pennsylvanian epoch the area included in the present boundaries of Missouri was above sea-level. The highest part 'was a plateau corresponding roughly with a tongue projecting into the northeastern part of the State a short distance west of the site of the Mississippi. The region now occupied by the main body of the Pennsylvanian was lower, though probably the difference in altitude of the two areas was slight. Meanwhile sediments were being deposited in shallow seas occupying parts of Oklahoma, Arkansas, and northern Illinois and the waters were slowly advancing over adjacent land areas ***."

[Near the beginning of the Allegheny (Cherokee or Henrietta)] "The land area had been reduced to an island in southeastern Missouri, with a peninsula projecting into Pike and neighboring counties and a small part of a northern land-mass in the extreme northwestern corner of the State. The western sea continued to advance eastward, while an eastern sea occupying most of Illinois advanced westward. Probably by the end of Cherokee time the two seas had joined, submerging practically all of northern Missouri and possibly nearly all of southern Missouri also. No deposition appears to have taken place at this time in the extreme northwestern corner of the State, for the Nebraska City drilling shows less than Ioo feet of Des Moines strata, probably of Pleasanton age.

"There is still much doubt as to whether the Pennsylvanian sea finally covered practically all of southern Missouri and submerged the Ozarks, though the evidence in hand seems to indicate that a large part of the region was inundated for a comparatively short interval, beginning, probably, near the end of the Cherokee epoch. In nearly all the Ozark counties there are small outliers or pockets of shale, sandstone, and coal in sink holes and other protected situations. Many of these, at least, are of Pennsylvanian age, but were probably deposited before invasion or after the sea receded from the region. The sink holes themselves were certainly formed while above ground-water level and some of them seem to have been deepened while being filled with Pennsylvanian coal and other materials. The remarkably thick pockets of cannel-a coal formed very slowly from only plant products most resistant to decay-were deposited in stagnant water that was probably fresh.

"In addition to the pockets, however, sandstone and shale of Pennsylvanian age are scattered over the Ozarks in small patches capping divides where erosion has not been active. These outliers may have been deposited at the time when the sea covered all or most of Missouri. The thinness of the probable marine

1 Hinds, Henry, and F. C. Green, The Stratigraphy of the Pennsylvanian Series in Missouri, Missouri Bureau of Geology and Mines, vol. XIII, 2d series, p. 208, 1915. 
Pennsylvanian sediments in all of the Ozarks, however, indicates that the sea may have retreated again in a comparatively short time, probably before the end of the Des Moines epoch. If the Warrensburg and Moberly channels came into existence late in the Pleasanton epoch, as seems probable, a relative uplift of the Ozark took place at that time. Moreover, the differences in the sediments laid down in Missouri and Illinois during the Missouri epoch, so far as known from strata still intact, point toward the presence of a land-mass between the two areas during that interval. Some of the sands deposited in parts of the Missouri epoch are also most easily explained by postulating a land-mass in southern Missouri. The overlap of Des Moines strata toward the west and the probable derivation of some early Des Moines sediments from an Ozark land-mass, on the other hand, seem to show that the Ozarks were above sea until late in the Cherokee epoch. ***

"Sedimentation during Missouri Epoch.

"The Missouri group seems to have been deposited under conditions which alternated between those of quiet waters, which permitted the growth of marine invertebrates but excluded clastic sediments to a large degree, and those of unsettled and disturbed waters in which sandstones and shales were deposited. From time to time the more unsettled conditions changed during short intervals in which lenticular coal or limestone beds were formed. While quiet waters prevailed and calcareous materials were conspicuous among the sediments, conditions were unfavorable for extensive plant growth. Even at other times coalforming plants succeeded in establishing themselves only for relatively short intervals and, with one or two exceptions, in comparatively small swamps. The intervals of limestone deposition, on the whole, grew shorter as time progressed.

"One of the notable features of the deposition during the Missouri epoch was the repetition of an alternating succession of limestones and thin shales with thicker shales and sandstones. Almost exactly similar conditions of sedimentation appear to have recurred intermittently over wide areas. There is a striking similarity in the Plattsburg and Stanton, Oread, and Deer Creek limestones and to a less degree in the Lecompton, Topeka, and Howard, and the Tarkio and cap-rock limestone of the Nyman coal. In each case the sections show only minor variations from the following succession:
I. Limestone, flaggy; a thin bed (at top).
2. Shale, drab; a few feet.
5. Limestone, dark gray; even-bedded; 1 or 2 feet.
6. Shale, drab.
7. Limestone, blue (at base).

4. Shale, black, slaty.

"In the Plattsburg and Stanton, Oread, and Deer Creek members this succession is typically shown. In the other cases mentioned the place of the dark-gray, even-bedded limestone (5) seems to be taken in some areas by coal, and the limestone (3) is much thinner.

"The clastic members have certain resemblances, which, however, are not nearly so striking as those just mentioned. Most of them contain sandstones that vary in apparent stratigraphic position within short distances, and include limestones that do not maintain uniform thicknesses.

\section{"Deformations.}

"From the beginning to the end of Pennsylvanian time in Missouri earth movements in the region now occupied by the series were relatively slow, simple, 
and uniform. In general there was a long-continued subsidence of the region, broken by periods of stability and with, perhaps, relative uplift of adjacent land areas during several intervals. The uniformity of the subsidence is shown by the persistence in thickness, areal extent, and character of most of the members of most of the formations. The periods of stability culminated in the formation of the widespread coal beds, after sedimentation had filled the sea and caused its withdrawal, and ended when a renewal of subsidence again let in the saline waters, killing the coal plants.

"The relative uplift of neighboring land areas is indicated by the periodic recurrence of irregular deposition and a comparatively large proportion of arenaceous sediments. In most Pennsylvanian formations the strata are remarkably persistent and regular, but in the Pleasanton, Douglas, and part of the Cherokee formations, and in the Lane, Severy, Scranton, and a few other members, the strata are variable. An influx of sands was usually caused, probably, by changes in the currents of the shallow sea, in the direction of drainage lines on neighboring land-masses, or in the derivation of sediments. During the Pleasanton and Douglas epochs, however, the phenomena were somewhat more complex. As stated more fully on previous pages, there is evidence that the sea may have withdrawn from all or part of Missouri in both Pleasanton and Lawrence time, while long and rather deep channels were formed by subaerial erosion. These changes appear to have been effected by slight tilting and folding in northern and western Missouri, as well as by differential uplift of the Ozark region.

"After the close of the Pennsylvanian there were two periods of folding. The first of these resulted in the blocking-out of the main broad features of the present structure, namely, the monoclinal dip to the west in north Missouri and to the northwest in the west-central part of the State. The second period of folding caused the formation of narrow and comparatively sharp anticlines and associated synclines trending northwest-southeast and markedly parallel throughout the State. ***" 


\section{CHAPTER III.}

\section{THE PLAINS PROVINCE.}

The Plains Province of deposition in Permo-Carboniferous time was in all probability a continuous whole, as described in Publication 207 of the Carnegie Institution, with a gradually shrinking body of clear water surrounded by large areas of red-bed deposition traceable from the Black Hills of South Dakota to New Mexico along the eastern front of the Rocky Mountains. The red beds deposited, in all probability, on the eastern side of the shrinking body of water have either been removed by erosion north of southern Kansas or are covered by younger deposits. The following summary description is given by States or by convenient units; it is obvious that the beds frequently extend across the artificial political boundaries.

\section{A. THE LATE PALEOZOIC IN KANSAS.}

The series of upper Paleozoic rocks in eastern Kansas is the most complete and illuminating of any section in the western portion of North America and is taken as the standard with which are compared the various exposures in the Plains Province. The long-drawn-out controversy as to the age of the upper Paleozoic rocks of Kansas has now little more than historic value, but it has, for good or ill, definitely attached to the upper part of the series the name Permian. This has been, with little doubt, the cause of much of the difference of opinion and the source of many of the controversial papers that have been published. Had this difficulty, more than half a historical matter, not persisted, the effort to find a sharp dividing-line between Pennsylvanian and Permian would not have been so vigorous or so long sustained, and a recognition of the essential similarity of the beds under the name Pennsylvanian and Permo-Carboniferous would have been much earlier recognized. As it is, the line between the "Permian" and Pennsylvanian has been forced downward by successive stages until now the Kansas lower "Permian" includes all the rocks from the base of the Elmdale formation to the top of the Wellington shales. These include series IV and $\mathrm{v}$ of the Kansas Geological Survey, with stages I, J, the Chase, Marion, and Wellington, as given by Beede in the volume IX of the Kansas University Geological Survey.

Whatever may be the final outcome of the controversy concerning the terminology of these beds, they are very certainly the equivalent of beds called Permo-Carboniferous elsewhere in the United States, and the author will consistently regard them as of such age in this work. 


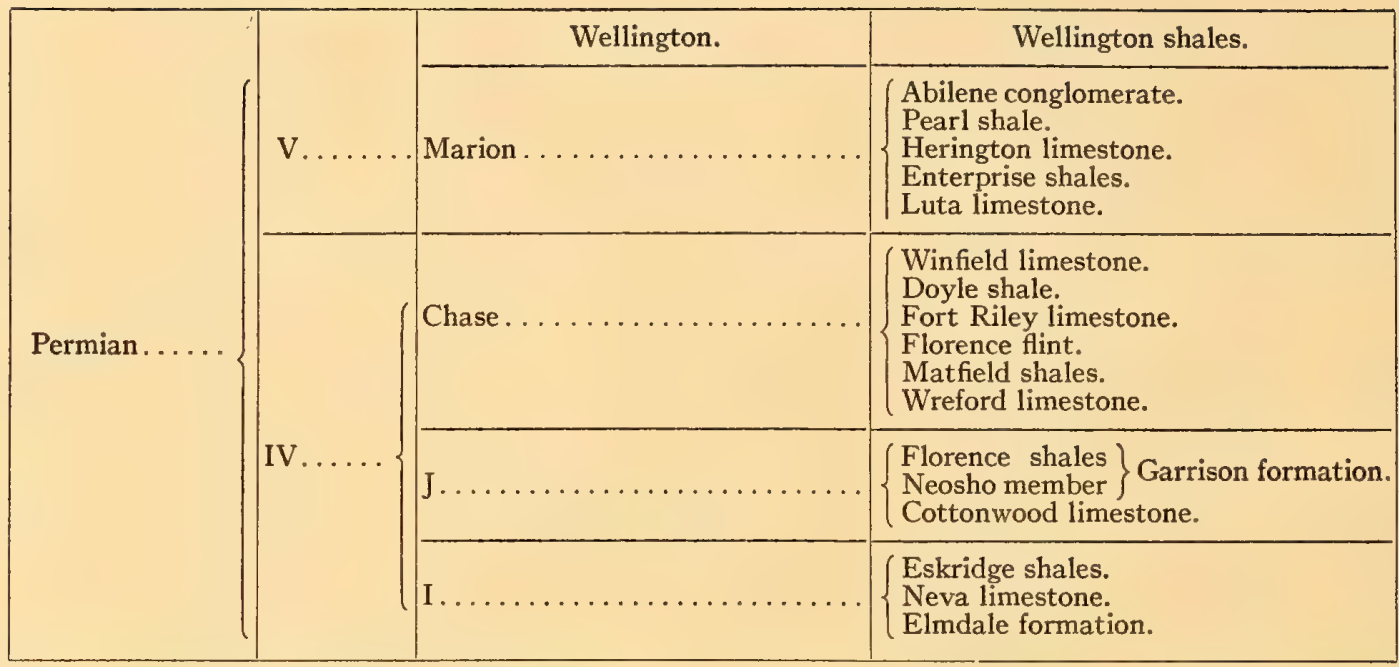

A detailed description of these beds is given by Prosser, ${ }^{1}$ from whose paper the following descriptions are quoted:

[Elmdale formation.] "It is about I30 feet in thickness, and composed of yellowish to bluish shales, with thin beds of grayish alternating limestone, including two or three thicker ones. About 30 feet above the base of the formation is a friable limestone with a thickness in some localities of 4 feet, which is composed to a large extent of the tests of Fusulina secalica Say. This stratum weathers rapidly and leaves great numbers of Fusulina in the soil. About 35 feet higher is another conspicuous yellowish limestone, the center of which weathers to a rough face, and from to to 5 feet below the top is a limestone stratum from 3 to 5 feet in thickness. $* * *$

"Neva limestone.-This formation consists of a massive bluish-gray limestone or of a lower and upper massive limestone, each one a little over 4 feet in thickness, separated by 2 feet of shales, with a total thickness of about Io feet. $* * *$

"Eskridge shales.—*** a mass of shales, with perhaps some thin limestone layers, varying from 30 to 40 feet in thickness. The shales are of greenish, chocolate, and yellowish color, and usually form covered slopes between the two conspicuous limiting limestones. $* * *$

[Cottonwood limestone.] - "This is a massive light gray to buff-colored, foraminiferal limestone, frequently composed of two layers with a thickness of about 6 feet. It contains very few fossils, with the exception of Fusulina secalica Say, which is extremely abundant in its upper part, ***" [called Alma limestone by Prosser].

"Garrison formation.-This formation is composed of two members, the yellowish fossiliferous shales at the base, formerly called the Cottonwood shales, and the upper one, composed of the alternating gray limestones and various colored shales called the Neosho, with a total thickness of from I40 to I 45 feet. The lower shales have a thickness of 13 feet near Strong, but decrease to 2 or 3 feet in the northern part of the state. $* * *$

1 Prosser, C. S., Revised Classification of the Upper Paleozoic Formations of Kansas, Jour. Geol., vol. X, p. 708, 1902 . 
[Garrison formation, Florena shales.] - "The upper member of the formation is composed of green, chocolate, and yellowish shales alternating with grayish limestones, while in the Big Blue valley a bed of gypsum occurs near the base. ***"

"Wreford limestone.-This formation is composed of limestone and chert, or flint, as it is popularly termed throughout the Flint Hills region, and varies in thickness from 35 to 50 feet. In general, it is composed of three strata, a cherty limestone below and above, separated by a heavy limestone nearly free from chert. The rock is buff color. $* * *$

"Matfield shales.-The formation is composed principally of variously colored shales, with some shaly buff, occasionally cherty limestones, and a light-gray limestone 2 feet or so in thickness, which occurs about 30 feet below its top. The thickness ranges from 60 to 70 feet, and it generally forms covered slopes between two massive and conspicuous flint ledges. * **"

"Florence flint.-This formation is about 20 feet in thickness and consists of very cherty limestone separated by definite layers of chert, with a band of shaly or white cellular limestone near the center. ***"

"Fort Riley limestone.-Overlying the Florence flint is a series of massive buff limestones, changing to thin-bedded and shaly strata in the upper part of the formation, which have a total thickness of 40 feet or more. Near the center of the formation are generally one or two massive layers, which on the weathered surface form a conspicuous ledge that may be readily followed by the eye for miles. ***"

"Doyle shales.-This formation is composed of variously colored shales with an occasional thin stratum of soft limestone, and has a thickness of 60 feet. About 20 feet above the base is a thin, grayish limestone which often appears on the surface, and at the top are yellowish shales containing a few fossils. ***"

"Winfield formation.-This has a thickness of about 25 feet, and is composed of a cherty limestone at the base with a massive concretionary one at the top, the two separated by yellowish shales. $* * *$ The chert is not so uniform in occurrence as in the Wreford and Florence flints, and at some localities this horizon is represented simply by a prominent light-gray limestone, nearly free from chert. *** The irregular worn upper surface of the concretionary limestone and the appearance of many of the concretions, as though rolled in the mud on the sea bottom, indicate a shallowing of the sea at this time, followed by a subsidence of the sea-bottom before the deposition of the succeeding even thinbedded limestones. This change of physical condition is indicated in the fauna by the nearly complete disappearance of the brachiopods and the survival of a fauna composed mainly of Permian lamellibranchs. ***"

"Marion formation.-Buff thin-bedded limestones and shales form the principal part of this formation $* * *$. The lower part is composed of rather soft, porous, thin-bedded limestones and shaly layers to shales, containing near the base a considerable number of siliceous geodes and occasionally some chert. Some 50 or 60 feet above the base is a buff limestone containing large numbers of lamellibranchs. ***”

"The upper portion of the formation is composed mostly of thin buff limestones similar to those in the lower portion, alternating with a greater thickness of shales and marls, and in some localities contains beds of gypsum and salt." [The top of the formation is a conglomerate, while at various localities and different levels beds of gypsum of varying thickness occur.] 
"Wellington shales.-This formation consists largely of bluish-gray to slatecolored shales, but contains some red ones, and in the southern part of the State beds of impure limestone and calcareous shales, together with occasional beds of gypsum and dolomite. Limited saline deposits are reported, but no rock salt."

This series has been shown by Beede and Sellards ${ }^{1}$ to be singularly persistent through the State. They say:

"From what has preceded it will be seen that the strata of the lower Permian are remarkably persistent and uniform when the great extent of the outcrop is considered. The Cottonwood limestone, though only about 6 feet thick, persists with every detail of structure and fauna over roo miles of strike and several times as great an outcrop, though it has not been identified with certainty in the southern part of the State. The Garrison formation extends entirely across the State, with but slight modifications in the southern part, such as the thickening of some of its limestones and the possible interpolation of others. The Wreford limestone is remarkably uniform throughout the entire distance from Nebraska to the southern line of Kansas, being most highly developed in the central part of its outcrop in the region of Cottonwood Falls. In the Matfield shales about the only change worthy of special notice is the thickening of a layer of limestone and the coming in of an additional one in the southern part of its outcrop. There are no striking changes in the Florence flint, aside from a slight fluctuation in its thickness, being somewhat thicker in the central and southern regions."

Toward the southern line of Kansas the limestones shade into sandstones and shales. This significant change is described by several authors.

"In tracing the outcrop ${ }^{2}$ of the limestone formations of the Carboniferous of Kansas, the writer observed that in going southward there is a gradual transition in the character of the sediments to those which are more arenaceous, and that there is a thickening of the shales and sandstones and a thinning and final disappearance of the limestones. $* * *$

"*** From what is known of the Permian limestones of Kansas, they will be found, when followed southward, to diminish in thickness, and this change will be accompanied by a transition to more sandy beds. ***"

The "Wellington Shales" are probably represented southwestward by formations which are red. The approximate limit of the red color is a line diagonal to the strike of the formations, and is found to correspond in a general way with a line drawn by Mr. Cummins as separating the Carboniferous and Permian.

"The distinctions which have been thus far outlined in Kansas do not hold where the rocks are followed southwestward along their strike into Indian Territory. Approximately along the Arkansas River, or a little south of that stream, the interstratified limestones disappear from that section, and the formations are accordingly shales and sandstones. Moreover, the rocks in Indian Territory gradually assume a red color in the higher portions of the section, the line of transition to this color being diagonal to the strike."

${ }^{1}$ Beede, J. W., and E. H. Sellards, Stratigraphy of the Eastern Outcrop of the Kansas Permian, Amer. Geol., p. I09, I905.

2 Adams, G. I., Carboniferous and Permian Age of the Red Beds, Amer. Jour. Sci., vol. xir, p. 383 , I901. A full description of conditions, with maps, is given by Adams in the Bulletin of the Geological Society of America, vol. I4, p. I9I, and in Bull. 21 I, U. S. Geological Survey, 1903 . 
In I909, Beede ${ }^{1}$ gave the following account of the transgression of the red color into the limestones:

"The limestones do not all continue to the southern limit of Kansas, some of them pinching out before reaching the Oklahoma line and others soon after crossing it. Few of them pass beyond the Arkansas River in that State. It seems that the central part of the Kansas Basin may have been to the northwestward during later Pennsylvanian time, since the shales frequently become thinner, and the limestones thicker in that direction, though this can not be said of the lower part of the section. Above the Americus limestone the succession of limestones and shales continues for about 700 feet. However, the shales become more calcareous and marly, the limestones more porous and less crystalline; massive gypsum beds are intercalated, and coal in quantities is wanting. The limestones also weather white. These changes are significant of decided physical or climatic changes, as the local pools of the lower horizons showed no tendency to concentrate and form massive gypsum deposits. Probably, also, the changed aspect of the limestones is indicative of these altered conditions. The first large deposits of gypsum occur just above the Cottonwood limestone in the lower part of the Garrison formation (Neosho member). Above these are the Wreford limestone, Florence flint, Fort Riley and Winfield limestones, heavily charged with chert, and separated by thick layers of shale. The outcrops of these formations form the 'Flint Hills' of the eastern part of central Kansas. Over these strata are two soft limestones with three intervening shale beds and a variegated, brecciated, thin limestone. These are grouped in the Marion stage, and end the regular succession of limestones and shales. Over the rocks of the Marion stage lie the Wellington shales, probably several hundred feet in thickness, composed of blue, green, and some red shales. Upon these shales lie I, 400 feet of red beds in Kansas. The upper part of the Red Beds does not occur in Kansas, but is found in western Oklahoma and the Panhandle of Texas.

"The whole of the lower succession of shales and limestones forming lowlands and low escarpments divide this section of continuous sedimentation into short stratigraphic units of great lateral extent convenient for paleontologic study.

"In Oklahoma different conditions prevailed during much of the time represented by the Kansas deposits, above the Cherokee shales.

"Passing-from Kansas to Oklahoma, the light-colored shales and limestones of the upper part of the Kansas section grade off into red shales and sandstones. The lowest horizon in Oklahoma at which the red sediments predominate is unknown, inasmuch as the strike of the rocks is but little west of south, and the Red Beds protrude eastward in central Oklahoma as a sort of embayment, especially north of the Arbuckle Mountains.

"In the region south of the western end of the Arbuckles the Red Beds lie unconformably upon the tilted and eroded Pennsylvanian rocks. It appears that the Albany-Wichita sea of northwest Texas transgressed over this region during a time of slight depression, the waters covering the western end of the Arbuckle Mountains, swinging eastward on their northern slope as far as the Seminole country. According to Cummins, there is no unconformity in Texas between the lighter sediments and the Red Beds, the transition between the

${ }^{1}$ Beede, J. W., The Bearing of the Stratigraphic History and Invertebrate Fossils on the Age of the Anthracolithic Rocks of Kansas and Oklahoma, Jour. Geol., vol. xvII, p. $7 \mathrm{I} 2$, 1909. 
Albany and the Wichita being a gradual lateral one. The transgression of the Red Beds in the Arbuckle Mountains may, then, be regarded as a northeastern or eastern encroachment of the Wichita sea-or conditions of sedimentation, as all these beds may not be marine. Whether this Arbuckle unconformity extends northeastward to the easternmost limit of the Red Beds has not yet been determined, and indeed may be very difficult to determine, where the unconformity would resolve itself to a mere disconformity of layers of shales, and perhaps accompanied by a greater or less reworking of the lower deposits. Gould, who has been over this region between the Arbuckles and the Arkansas River many times, states that he knows of no unconformity. If no unconformity exists to the north of the Arbuckle Mountains, it seems probable that the first Permian emergence began here and the deposition of the red beds in the Seminole country is the first record of it, the later sediments from the Arbuckles reaching farther north. Regarding the gradation of the upper part of the Kansas section into the Red Beds in northern Oklahoma, there can be no doubt whatever, and the same is probably true of the central part of the State.

"The Arbuckle and Wichita mountains are probably the source of much of the red sediment in which they are partially buried, and the former mountains are directly responsible for the eastern extension of these beds into central Oklahoma. The extent to which the lighter-colored sediments of Kansas and Texas are replaced by red sediments in Oklahoma and near it represents in a rough way the limits of the influence of these mountains on the deposits of the time by the spread of their sediments. By the time the deposition of the lightcolored sediments had ceased the conditions had become such that nearly all the sediments derived from the land surrounding this basin were red.

"In the Oklahoma region the deposition of red sediments began, perhaps, as low as the Howard or Topeka limestones, and perhaps as high as the Emporia or Americus limestones. The deposits then seem to be uninterrupted until the unconformity below the Dockum beds (Triassic) in the Texas Panhandle is reached. Some of these beds appear to be of subaerial origin, as has been shown by Case, while others are certainly marine. Careful petrologic study will probably demonstrate that much of the arenaceous material is windblown sediment, more or less reworked by currents or waves as the regions were submerged or flooded. That the sea ever covered the entire area from Kansas to southern Texas and New Mexico at one time may be questioned. If it did, the sediments contained were of such a nature and abundance, or the waters so concentrated, as to preclude the free migration of a normal marine fauna throughout the basin. That marine conditions prevailed, at least locally, is demonstrated by the Whitehorse and Dozier faunas.

"In Texas normal deposits were laid down in higher horizons than in Oklahoma, and in Kansas there are reasons for believing that the light-colored sediments were laid down at an even later date than in Texas. These conditions are illustrated in the subjoined table, showing a vertical section of the Carboniferous and Permian rocks of the three States.

"The extent of this post-Pennsylvania basin seems to have been very great. It included much of Kansas (two-thirds), western Oklahoma, much of western Texas, and all of New Mexico, Colorado, and Wyoming east of the Rocky Mountain axis. In area it probably aggregated 300,000 square miles.

"Together with the varied physical conditions of these three regions went corresponding faunal peculiarities. In the Albany division of the Texas rocks 
the Pennsylvanian elements of the fauna seemed to persist, while they are largely wanting in their equivalent beds, the Wichita division. A similar thing occurs in the clear-water beds of northern Oklahoma and southern Kansas, north of the Red Beds. Aside from this general fact it should be noted that along the region of the Red Beds and light sediment (littoral?) contact, some of the Pennsylvanian elements of the Kansas fauna persisted much longer than in the same rocks to the northward. The fauna of any given horizon above the Elmdale formation varies very sensibly as we pass from the Nebraska to the Oklahoma line, both in abundance of specimens and species, and in the general aspect of the faunules as well. This is to be expected in the light of the intercalation of massive gypsum beds as low as the lower part of the Neosho member in the northern region. From it we would infer that the waters of the northern-main marine part of the basin were somewhat more concentrated than at its southern shore."

In I9I2, Beede ${ }^{1}$ gave a second account of the same phenomenon:

"In tracing the limestones and shales of the basal Permian beds of Kansas southward into Oklahoma the relationship of the light-colored sediments to the red sandstones, red shales, and red limestones of Oklahoma is clearly revealed. It is shown that some of the heavier ledges of limestone first become sandy along their outcrops in patches a few rods across. Farther south the sandstone areas increase in size until the limestone appears only in local areas in the sandstones and is finally wanting. Traced farther southward, the sandstones become deep red or brown with local areas of white. The decimation of the fauna sets in as the limestones diminish and the remains of life are not found far beyond the limits of the limestones. The shales become red very much farther north than do the sandstones, and are frequently more deeply colored. Some of the lower limestones become red before they change into sandstones. The sandstone ledges continue for some distance southward as rather even, uniform beds, but farther on they are found to thicken and thin in a somewhat systematic manner.

"Several ledges of sandstone frequently occur in a single section, and where one of these ledges is found thickened the others are apt to be thicker than normal. Likewise they are all found to be thin over certain areas. The regions of thickening and thinning were found to be parallel belts lying north and south at right angles to the major drainage lines. Two of these belts, together with an intervening region about 8 miles across, were studied. The sandstones thicken at the expense of the shales, sometimes eliminating them. In one instance a thin limestone was traced southwest into one of these zones. A sandstone 20 feet or more beneath the limestone thickens and rises above the limestone and practically unites with the sandstone some distance above it. The limestone seems to die out a few feet from the sandstone, but farther west the latter shrinks to its normal thickness and the limestone is present in its proper position with its usual characteristics."

A later paper by Beede ${ }^{2}$ gives a more detailed account of the transition of the limestone into shale and red beds:

${ }^{1}$ Beede, J. W., Origin of the Sediments and Coloring Matter of the Red Beds of Oklahoma, Science, vol. $\mathrm{xxxv}$, p. $348,1912$.

${ }^{2}$ Beede, J. W., The Neva Limestone in Northern Oklahoma, with Remarks upon the Correlation of the Vertebrate Fossil Beds of the State, Oklahoma Geological Survey, Bull. 21, p. 24, 1914. 
"One of the most interesting features of this whole region is the nature of the changes from the light-colored limestones and shales to the dark-red sandstones and peculiar shales of the Red Beds.

"The shales are red much farther north, as a rule, than are the limestones and sandstones. The change in color is frequently accompanied by some change in the character of the shale. The red shales are usually much less compact and durable and in the immediate region covered by this report seem to become more or less charged with very fine sand. On account of the fact that the shales are usually hidden from view, the nature of the transition has not been observed so carefully as has the transition from limestone to sandstone.

"In the case of some of the higher limestones, Wreford, Fort Riley, etc., sand appears in the limestones, which have usually thinned appreciably. The sand may gradually increase for considerable distances, say from a few rods to a few miles, and become first a sandy limestone, then a calcareous sandstone. Followed still farther, the traces of calcium carbonate disappear, sometimes to reappear as limestone in some areas. Again, as is shown along the Shawnee branch of the Santa Fe Railroad from Kaw City to Skedee, or the upper Wreford limestone at Hardy, the first traces of the transition are seen in purple blotches scattered through the stone. These may enlarge and increase in number until the whole stratum is practically a purple or red limestone. In other regions the limestone may turn almost scarlet in a rod or two, as in the case with a limestone in the escarpment south of Cushing. The red limestones of the latter class usually dissipate quickly into sandstones. They are usually fossiliferous.

"Sometimes a limestone layer will grade into a sandstone layer and then change back again into limestone in a few rods. Indeed, this is not infrequent in the region between Kaw City and Pawnee, and west and northwest of Pawnee. *** Sometimes these sandstone replacements may not be more than 3 or 4 rods across. $* * *$ The sandstone in such cases is usually calcareous, but in some instances it is not.

"At one point a ledge was made up of sandstone and limestone in indiscriminate masses, which were very irregular in form. The masses were all rather small, hardly ever over 2 feet in diameter and ranging from that to mere pockets. Sometimes there were pockets of sandstone in the limestone and sometimes pockets of limestone in the sandstone. That is, sometimes one or the other forms the predominating rock. On the whole, the exposure was largely limestone. In most all cases the transition from the light-colored sandstone to red sandstone takes place before going a great distance. $* * *$

"After passing some distance south or southwest of the region of transition just described, in which the sandstones maintain their usual thickness and relative positions, we pass into another zone where they thicken and thin, pinch out, end, and even cut out intervening beds of shale and limestone. *** In this region stratigraphic work becomes more uncertain, the fossils are wanting, and there seems to be no character of the rocks to tie to. At the bridge at Ripley is a sandstone about 40 feet in thickness which elsewhere is usually about 4 or 5 feet. All the sandstones of the section at Vinco are thicker than the average, but appear to pinch out on the south side of the river between Vinco and Goodnight, so far as it is possible to determine by surface exposures. At Goodnight they have more than normal thickness. These belts of thickened sandstones extend nearly north and south, with the region of very thin sandstones or mere traces of white sand and iron concretions marking their horizons between them. 
"These long stretches of sandstone extend from just west of Pawnee, nearly straight south to the vicinity of Shawnee, a distance of 60 miles on an air-line. Wherever the region of shales west of this belt was crossed, as near Lela, west of Stillwater, Goodnight, etc., another belt of thickened sandstones was found. Another feature of this region that must not be lost sight of is the fact that the lower horizons traced eastward grade out into normal light-colored beds of marine origin, at least nearly as far south as Shawnee. Whether these great masses of sand were thrown up as barriers along the southern tongue of the sea to the north and northeast, or whether they represent river debouchures from the mountains to the southward has not yet been determined. For a number of reasons, some of which will follow, the writer is at present inclined to the opinion that they are connected with rivers. With further work it appears now that the question can be settled quite definitely and the origin of the sediments determined. If they were barriers, it would seem peculiar that the different layers should thicken and thin so nearly simultaneously, while this is what would be expected if the sand were brought down to mouths of rivers whose channels at times extended well out across low fans, coastal plains, and shallow waters.

"In some places the deposition of sandstone is very irregular. Over some areas a sandstone may be wanting and its place apparently filled with soft shales that weather and slump very rapidly, forming great amphitheaters. In some instances the sandstones occupy beds cut in the soft shales by currents of some kind. ***

"Many of the peculiarities which have been described occur in the northern part of the State. Farther south, and especially farther west, they appear to be more complicated. Another feature that was noted was that some of the beds became quite coarse by the time the latitude of Shawnee was reached. Our studies did not extend south of Shawnee.

"The fact that the stratigraphy is more regular in the same horizons in the eastern part of the region studied than in their western extensions, as well as the fact that the same formations contained limestones with marine fossils at their eastern outcrop for some distance south of Pawnee, would seem to indicate that an arm of the sea at Neva time extended south from the great northern area as far as the Cimarron River, or a little beyond, but that its waters were extremely shallow, if present, on the flats west of the $96^{\circ} 45^{\prime}$ meridian. The disappearance of the fossils and the irregular and interrupted character of the stratification seems to indicate the passing from marine conditions on the northeast to shallow water or even subaerial conditions to the south and west. This would appear to be the direct result of the influence of the Arbuckle Mountain region upon the sedimentation of the time. Subaerial conditions continued near the mountains and marine conditions beyond the influence of its fans."

\section{B. THE LATE PALEOZOIC IN OKLAHOMA.}

The relation of the vertebrate-bearing horizons of the Texas and Oklahoma red beds to the Kansas limestones and shales is not and probably can not be exactly determined from the very nature of the deposits. Some few beds have been traced by Adams and Beede directly into Oklahoma, where they shade off into red shales and sandstones, but they are not vertebrate- 
bearing horizons. Beede ${ }^{1}$ gives the following statement, which is as near as we may hope to come at the present time:

The Cowley County, Kansas, vertebrates which are very similar to those from the Wichita formation in Texas come from 50 feet below the Wreford limestone in the Neosho division of the Garrison formation.

The vertebrates from the Eddy locality in Kay County, Oklahoma, which may be equivalent to either Wichita or Clear Fork forms, come from a horizon as high as the base of the Wellington shales, 460 feet above the Cowley County horizon.

The direct continuation of the Kansas Permo-Carboniferous beds into eastern Oklahoma has been emphasized by Gould: ${ }^{2}$

“*** while the Flint hills in Kansas consist almost entirely of limestones and shales, still on the southern line of the State sandstones have already begun to appear. To the south these conditions obtain more and more until the limestone is entirely replaced by sandstone. $* * *$ South of the State line the sandstones from the east and the red beds from the west begin to approach each other, while the limestone ledges become thinner and thinner, and the flint less pronounced.

"In general $* * *$, it may be observed that in going eastward from a redbeds region toward the Carboniferous the sandstones and shales, which have been of a deep brick-red color, become more and more brownish and grayish, and finally lose entirely their characteristic hue and take on that of the older formations. The lithology changes also. ***

"The Marion and Wellington formations $s^{3}$ narrow rapidly in northern Oklahoma, and their place is taken by the red beds. Perhaps it is more correct to state that the color of the shales appears to change to the south, and to become red, while at the same time more of the red sandstone comes in, all tending to change the formation in lithological appearance to that of typical red beds.

"A section of the Twin Hills, 7 miles east of Ingalls, eastern Oklahoma, shows three ledges of limestone, the thickest of which is not more than 4 feet, while all the rest of the rocks are either red shales or sandstones. Above these limestones are ledges of grayish or red sandstones, which thicken to the south and west, and, in the region between Stillwater and Orlando, assume the red tint so common in the red beds. $* * *$ The line of separation between the rocks of these two ages [Carboniferous and Permian] must finally be drawn far out in the red beds."

“*** These formations $\mathrm{s}^{4}$ [Marion and Wellington] narrow rapidly in northern Oklahoma, and their place is taken by the red beds. Perhaps it is more correct to state that the color of the shales changes to the south, becoming red, while at the same time more of the red sandstone comes in, so that finally the formation

${ }^{1}$ Beede, J. W., The Neva Limestone in Northern Oklahoma, with Remarks upon the Correlation of the Vertebrate Fossil Beds of the State, Oklahoma Geological Survey Bull. 21, p. 36, 1914 .

${ }^{2}$ Gould, C. N., Notes on the Geology of Parts of the Seminole, Creek, Cherokee, and Osage Nations, Amer. Jour. Sci., vol. II, p. I85, I901.

${ }^{3}$ Gould, C. N., General Geology of Oklahoma, Second Biannual Report Oklahoma Geological and Natural History Survey, p. 27, 1902.

- Gould, C. N., Geology and Water Resources of Oklahoma, U. S. Geological Survey, Water Supply and Irrigation Paper No. 148, p. 35, 1905. 
changes to typical red beds. On the State line, the distance from the Winfield formation, the upper conspicuous limestone member, to the eastern outcrop of the red beds is perhaps 30 miles; on the southern line of Kay County, Oklahoma, it is not more than I5 miles, while farther south the line of separation can not be determined, for the reason that the limestone disappears, and its place is taken by red shales and sandstones. In southern Kansas there are three distinct kinds of Permian rocks: First, the heavy limestones in eastern Cowley County and along Walnut River: second, the bluish and gray clays and shales of the Marion and Wellington formations from Walnut River to western Sumner County; and, third, the typical red beds, consisting of red sandstones and clays extending from this point nearly to the west line of the State. In eastern Oklahoma, on the other hand, only red beds appear.

"Thus it is seen that the red beds extend farther east in Oklahoma than in Kansas, and that the eastern limit of the red beds does not coincide with the line of separation between the Pennsylvanian and the Permian. In other words, the red color of the rocks, which has been thought characteristic of only the Permian of the region, in fact transgresses far into the region of the Pennsylvanian rocks. This means, of course, that the line of separation between the rocks of these two epochs must finally be drawn far out in the red beds, and this the writer has attempted to do.

"The horizon of the bone beds of Texas is an extended one, and probably does not correspond to any one horizon in Kansas or Oklahoma, but to several of them. Dumble's correlation of the Phacoceras dumbeli zone of the Wichita formation with the Fort Riley limestone is probably about as near correct as we can state at the present time."

Gould further states that the vertebrates from the Pittsburgh red shale in Pennsylvania are from a horizon equal to the Oread limestone, I,000 feet above the Cowley County horizon, and that the vertebrates from near Danville, Illinois, are from a horizon which it is certain "that there is no reason for supposing that the surrounding shales are as high stratigraphically as the basal Permian of Kansas."

In a discussion of the upper Pennsylvanian rocks of eastern Oklahoma, Gould $^{1}$ and others have included deposits as high as the equivalent of the Garrison formation. They show that the limestones and shales below the Wreford become sandy toward the south and many of them disappear before the Arkansas River is reached. Of the I0,000 to 12,000 feet of shales or sandstones reaching from the Mississippian to the Permian (well into the Permo-Carboniferous-Case) the shales greatly predominate. While it is apparent that the limestone thins out and disappears to the south, there are present some limestones as far north as Bartlesville and Tulsa which thin out to the north, having all the appearance of detached lenses. The shales and sandstones constantly increase in thickness and frequently coalesce. The two upper groups recognized in eastern Oklahoma are the: Ralston, from the base of the Pawhuska to the base of the Wreford; Sapulpa,

${ }^{1}$ Gould, C. H., D. W. Ohern, and L. I. Hutchinson, Proposed Groups of Pennsylvanian of Eastern Oklahoma, Research Bulletin State University of Oklahoma No. 3, r9ro. 
from the base of the Lenapah to the Pawhuska, which equals the Deer Creek and Hartford of Kansas. The details of the stratigraphy of the Red Beds in Oklahoma are summarized in Publication 207 of the Carnegie Institution, pages $5 \mathrm{I}$ and 56 , and need not be repeated here.

\section{THE LATE PALEOZOIC IN TEXAS AND NEW MEXICO.}

A very full description of the stratigraphy of the Permo-Carboniferous red beds of north central Texas was given in Publication 207 of the Carnegie Institution, pages I9 to $4 \mathrm{I}$, and need not be repeated, but some repetition of the accounts of the shading of the red beds into the limestones is necessary. Cummins in 1897 described the gradual change from red shale to limestone on the south and southeast side of the red beds: ${ }^{1}$

"By walking along the outcrop every foot of the way we were enabled to note the gradual change in the lithological character of the bed. [Following a prominent bed of the Albany northeastward we found] the limestone $* * *$ gradually changed in composition to a calcareous sandy clay, entirely destitute of fossils $* * *$. North of the Brazos River, in the area heretofore designated as the Wichita division in previous reports, the strata of the escarpment became more and more composed of red clay, and the limestone beds less conspicuous. The limestone gradually loses its limy nature."

Gordon records the same observations:"

"The red sandy shales and red standsones so conspicuous in the Wichita Valley region were replaced southward in large part by blue shales, light-colored sandstones, and limestones. In some places the transition from a sandstone to a limestone was plainly seen. $* * *$ It is the conclusion of the author that the red beds of this region are the near-shore representatives of the Albany and the decision as to their age will rest upon that of the latter."

In I9I I, Gordon, ${ }^{3}$ discussing the relation of the Albany to the Wichita, says:

"When traced northward, the limestones of both the 'Albany' and the Cisco formations diminish in thickness, while there is a corresponding increase in the intervening beds of shale. In the case of the 'Albany,' the limestones show also a change, becoming more earthy and irregular in their texture, and some of the beds passing into gray indurated clays. The few limestones in the upper part of the Cisco formation disappear entirely in the northern part of Young County. Along with this change there is an increasing development of red clay, alternating with blue.

"At Fane Mountain, a low elevation in the southeastern corner of Throckmorton County, is an outcropping of limestone characterized by an abundance of Myalina permiana. These beds occur at intervals northward in eastern Throckmorton County, and at Spring Creek in the northwestern corner of Young

${ }^{1}$ Cummins, W. F., The Texas Permian, Trans. Texas Acad. Sci., vol. II, No. I, p. 95, 1897.

${ }^{2}$ Gordon, C. H., The Red Beds of the Wichita-Brazos Region of North Texas (Abstract), Science, vol. 29, p. 752, 1909.

${ }^{3}$ Gordon, C. H., The Wichita Formation of Northern Texas, Jour. Geol., vol. I9, p. I I8, I9I I. 
County they outcrop in the bank of the river about a mile from the post-office. Here the beds show a local gradation into sandstone, suggesting near-shore conditions of sedimentation. $* * *$

"Nowhere in the southern area, so far as observed, are there any indications of unconformity. Notwithstanding the lithological and faunal characteristics which distinguish the 'Albany,' these beds appear perfectly conformable with the Cisco below and the Clear Fork above, nor is there within the formation any indication of stratigraphic discordance. The change in the lithological character of the beds toward the north is evidently the result of differences in the conditions of sedimentation. The character of this part of the formation suggests very strongly its origin on a coastal plain, or river delta, to the south and west of which lay the sea, in which were deposited the marine 'Albany' sediments. The interrelations of the two kinds of sediments suggest oscillation of the shore-line upon a relatively wide coastal plain. These changes may be explained as the result of oscillations of the land surface, or, possibly better, by the slow, but intermittent, sinking of the coastal region."

In a later paper Gordon ${ }^{1}$ further discussed this point:

"A feature of importance in the Cisco formation, and one which it shares with the next succeeding formation, is the series of changes observed as the formation is traced northward along the strike. These changes relate both to variation in lithologic character and to thickness of beds. In the Colorado Valley, interstratified with the sandstones, clays, and conglomerates, are six or more beds of limestone, each from 5 to 25 feet thick and all aggregating a thickness of Ioo to I 50 feet. In the southern part of the Brazos Valley the calcareous divisions are only about half as thick as they are farther south, and the clays show a corresponding increase in thickness. In Young County the calcareous material diminishes northward at an increased rate until, at the northern boundary of the county, the limestones have practically disappeared, and beyond that point they are represented apparently by irregular nodular masses of earthy limestone in a matrix of clay. With the thinning out of the limestones the shales and sandstones increase in thickness. In Stephens County, and farther south, the shales are prevailingly blue and sandstones gray. Red Beds are dispersed sparingly through the formation. The blues gradually give place to reds until in the vicinity of Red River the red color dominates. In this part of the region the rocks consist, for the most part, of red sandstones, clays, and sandy shales, with a few beds of blue shale and bluish to grayish-white sandstones. Limestones are conspicuously absent. $* * *$

"Beds of red clay make their appearance south of Young County, but they increase notably to the north, especially in the upper part of the formation, along with the diminution of the limestones, and they constitute the dominant feature of the formation in eastern Clay and western Montague Counties."

On the western side of the Red Beds areas of Kansas, Oklahoma, and Texas the sandstones and shales pass unchanged beneath the Mesozoic and Tertiary deposits of the Staked Plains. The western border of the Plains Province of deposition lies close to Front Ranges of the Rocky Mountains.

The stratigraphy of the western border of the Red Beds in the States

\footnotetext{
${ }^{1}$ Gordon, C. H., U. S. Geological Survey, Water Supply and Irrigation Paper No. 317, pp. 18-20, 1913.
} 
mentioned is still unsettled. Fragments of vertebrates of Wichita or Clear Fork age were collected by the author near Buffalo Gap, a few miles south of Abilene, Texas, ${ }^{1}$ and west of the region between Abilene and San Angelo no beds were encountered that could be correlated with the Double Mountain. Ten miles east of Big Springs, Texas, the red shales and sandstones carry Triassic fossils. From Mitchell County to as far north as Briscoe County in Texas the uppermost Permo-Carboniferous beds are of Double Mountain age; beyond that to the north, the position of the uppermost red beds is less certain. In the Panhandle of Texas the exposures of red beds in the Canadian River are probably the equivalent of the Greer and Quartermaster (Whitehorse) of Oklahoma; the latter, at least, Gould considers as entirely above the Cimmaron of Kansas. There is a strong suggestion of a longer continuation of red-beds conditions in this region or an excessive supply of material. Around the southern end of the Staked Plains the exposure of the red beds is interrupted by the overlying Tertiary and Mesozoic deposits. Between Big Springs and Midland the narrow strip of red beds is apparently all Triassac, but there has been no conclusive evidence of their age, either stratigraphic or paleontologic, reported. From Midland to the Pecos River the exposed material is all Tertiary, but at the bridge across the Pecos, on the Fort Stockton road, 20 miles east of Grand Falls, and in the bed of the river near Grand Falls, there are exposures of red shale and sandstone very similar in lithologic character to certain phases of the Double Mountain formation of north central Texas. From Grand Falls to Pecos only red sands and disintegrated red shale are exposed, but on the east side of the Pecos River red beds again appear. The author has been unable to obtain any evidence for the Permo-Carboniferous age of these red beds other than their red color and assumed stratigraphic position. They were first called Permian by Marcou in 1852 , and the designation seems to have clung for lack of any definite evidence to the contrary. Cummins, ${ }^{2}$ in 1891 , said:

"We found no fossils in the beds west of the Plains, but as we had traced the formation on both the eastern and northern sides there was no doubt as to its being the same when we found it upon the west. *** The strata lie unconformably on the Carboniferous, dipping at a small angle to the southeast."

The red beds are seen only in isolated patches from Pecos north nearly to Roswell, as they crop out from below the Tertiary covering. The best exposure is just east of Roswell. The following description of the section is given by Fisher: ${ }^{3}$

${ }^{1}$ Carnegie Inst. Wash., Year Book, p. 374, I916.

${ }^{2}$ Cummins, W. F., Notes on the Geology of the Country West of the Plains, Third Annual Report Geological Survey of Texas, p. 212, I89I.

${ }^{3}$ Fisher, C. A., Preliminary Report on the Geology and Underground Waters of the Roswell Artesian Area, New Mexico, Water Supply and Irrigation Paper No. I58, U. S. Geological Survey, p. 6, 1906. 
"The rocks of the [Roswell] district comprise limestone, sandstone, clay, and gypsum which are believed to be of Permian age.*** The so-called Permian series of this district consists of an upper red bed member of gypsum, red sand, limestone, and clay 600 feet thick, forming the high bluffs along the east side of Pecos River and underlying the recent deposits of Pecos Valley, and a lower member of massive limestone, clay, and gypsum of undetermined thickness, which constitutes high rugged slopes to the west. ***

\section{"Permian (?) Series.}

"Red-bed division.-These rocks consist of alternating beds of gypsum, red sand, and clay, with an occasional layer of dark-gray, compact limestone. The gypsum predominates and usually occurs in beds about ro feet thick. It is often found, however, in thinner layers, interbedded with clay and limestone. The red beds are provisionally placed in the Permian, although no fossils have been found in them. ${ }^{*} * *$ The upper part of the beds is well exposed in the bluffs along the east side of Pecos River, where a number of sections have been measured.

A typical section of this bluff is as follows:

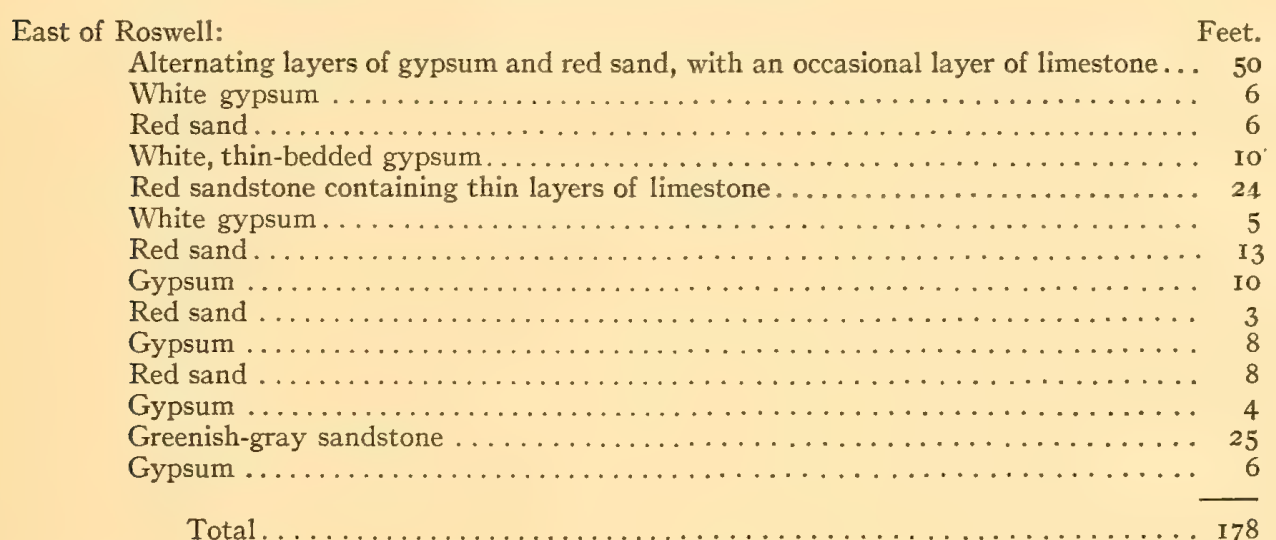

"Limestone dirision.-The massive limestone beds underlying the so-called Permian red beds of this region consist mainly of gray, compact limestone, with layers of soft sandstone, clay, and gypsum. In the upper part the limestone is more or less thin-bedded and porous, and contains many sandy layers. $* * *$ Limestone outcrops along the west side of the district, and farther to the west forms high, rugged plateaus, extending toward the mountains. Fossils are not abundant in the formation, but in one locality northwest of Roswell a number were collected, which consisted mainly of Schizodus and Pleurophorus, preserved as casts. According to Doctor Girty, the fauna and lithology of these specimens suggest the highest Carboniferous beds or the Permian of the Mississippi Valley in Texas."

Beede $^{l}$ has maintained that the red beds of the eastern side of the Pecos Valley are equivalent to, or a continuation of, the upper red beds of Texas and Oklahoma. He shows that the Capitan and Delaware limestones shade north and east into red sandstones and shales, which he regards as a

${ }^{1}$ Beede, J. W., The Correlation of the Guadalupian and the Kansas Sections, Amer. Jour. Sci., vol. $\mathrm{xxx}$, p. I3I, I9I0. 
continuation of those to the east, and maintains that the conditions which determined this change separated the fauna of Capitan limestone from that of the Quartermaster (Whitehorse) of Texas and Oklahoma. He says:

"If the conclusions reached above are correct, it leads at once to the correlation of the Kansas and Guadalupian sections. If we use the Whitehorse sandstone, probably the equivalent of the beds in contact with the Guadalupian limestone near Carlsbad, as a common basis of correlation of the two sections, we attain the result shown in the accompanying diagram. [Fig. 2.] Disregarding their actual faunal relationships and comparing them as to their thickness, the strata of the two sections compare as follows, the figures of the Guadalupian rocks being approximations:

"In southern New Mexico we have some 4,500 feet of the Guadalupian series, composed of 2,100 feet of Capitan and overlying limestones, and 2,400 feet of the Delaware Mountain formation, composed of limestones and sandstones overlying 5,00o feet of Hueco limestones. Beginning at the same horizon in Kansas, we have the remainder of the Red Beds, the lighter Permian and the Pennsylvanian, aggregating about 4,500 feet of strata, composed of limestone shales and sandstone. So far as mere thickness is concerned, it leaves the base of the Delaware Mountain formation about on the level with the Cherokee shales (as exhibited in Kansas). The horizon of the base of the Delaware Mountain formation in the Kansas section, interpreted upon its fauna, or actual time equivalency, may be a very different matter. The base of the Capitan falls near the bottom of the Elmdale formation stratigraphically, which is probably not far from its correct faunal correlation as well. The paleontological

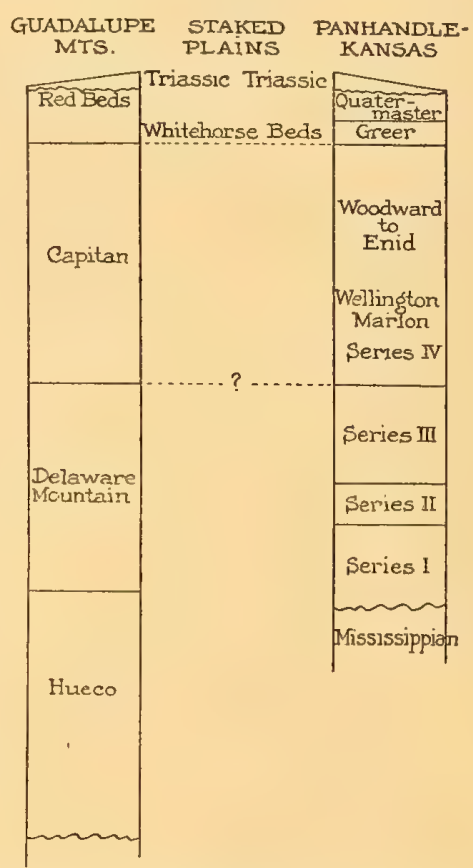

FIG. 2.-Diagram from Beede, showing his idea of the relations of the beds in the Guadalupe Mountains to those in Texas and Kansas.

comparisons are yet to be worked out. The unconformity above the Capitan limestone, and locally even in the Delaware Mountain formation, the Capitan having been carried away, is not taken into account in making these comparisons. It is probable that it diminishes rapidly to the northward, where it is of less consequence.

"One of the most interesting features of the Guadalupian fauna is its isolation. As has been stated by Girty, the fauna is a unique one, and, as a unit, is now known from no other part of the western hemisphere. At first thought it seems peculiar that more of its members were not distributed over the adjacent regions where contemporaneous strata occur. Their absence in such rocks has been a serious difficulty in any attempt to correlate them with other American faunas.

"In the first place, the lower red beds lying to the eastward, with which the Guadalupian limestones are probably contemporaneous, are believed by some to be to a considerable extent of subaerial origin, while the temporary seas that occupied portions of it from time to time were too concentrated in salt content for normal marine faunas. So far as my collecting in the typical Capitan limestone 
goes, the fossils were abundant only in the purer limestones, and were very rare, or wanting in what appeared to be the dolomitic portions of it. These limestones occur in the Apache Mountains and at Guadalupe Point, but appear to be wanting, as does the fauna, north of the Texas line; the only exceptions noted were Fusulina elongata and one or two other species in Dog Canyon and Sitting Bull Canyon. From this it will be seen that the fauna was closed off on the north by untoward conditions and on the east by the red-bed sedimentation, which constituted a barrier. No other barrier is known.

"Two other considerations must be taken into account. First, that the Permian facies of this fauna may be an abnormally early precursor of the Permian faunas developed in an isolated basin. Such an occurrence of Permian forms is known in Kansas well down in deposits of Pennsylvanian age. However, the variety and richness of the Guadalupian fauna, which possess such a young appearance, seem to me to argue against this hypothesis. Second, the other possibility is that the fauna is no older than it appears, and that it developed normally with little outside connection, as did the Kansas Permian fauna. The same features as before would have controlled its isolation. Much of the red beds being almost a land surface a considerable part of the time - if we accept the subaerial origin of a large part of the deposits-aggradation may have but slightly overbalanced degradation, and they may have accumulated slowly for that class of sediments. Thus, though disturbances raised the southern part of the Guadalupe limestones above sea-level, and permitted their partial removal and the subsequent deposition of the upper red beds upon the eroded surface, the fauna may well have been an early Permian fauna. Until further data are at hand I am much inclined to this latter hypothesis. The fact that several hundred feet of the Kansas Permian deposits grade off into typical red beds in a very short distance in Oklahoma is suggestive of possible conditions east of the Guadalupes. If such were the case, we would expect the Guadalupian faunas to cease as abruptly upon the strata changing to the red beds, as the Kansas faunas do upon entering the Oklahoma red beds.

"At the same time, owing to the very nature of the origin of the red beds, their extreme southwestern part may have been deposited slightly later than the main mass farther to the north and east. However, this is regarded more in the nature of a possibility than a probability.

"The accompanying map [fig. 3] indicates the probable relationship of the marine areas during the Council Grove-Chase and Guadalupian time in the immediate area under consideration. No attempt is made to show the full extent of deposits laid down at this time. The full lines indicate marine conditions and the lines alternating with stippled ones continental-marine deposition. The extent to which the two factors contributed to the formation of the red beds is at present unknown. The area of marine conditions in Central Texas is to represent the Albany sea."

This position has been contested by Girty, as is shown below (page I44), and the difficulty of such a correlation is quickly apparent when the relation of the Pecos beds to the Delaware and Capitan limestone is understood. As has been shown by Richardson and others, the Castile gypsum and the Rustler limestone lie beneath the red beds of the Pecos Valley, and there is every reason to believe that these are equivalent to the uppermost red beds of Texas or the Triassic red beds; probably both are represented in the better 
sections. The Rustler limestone lies upon an eroded surface of the Delaware limestone and very probably this eroded surface was at one time covered by Capitan limestone.

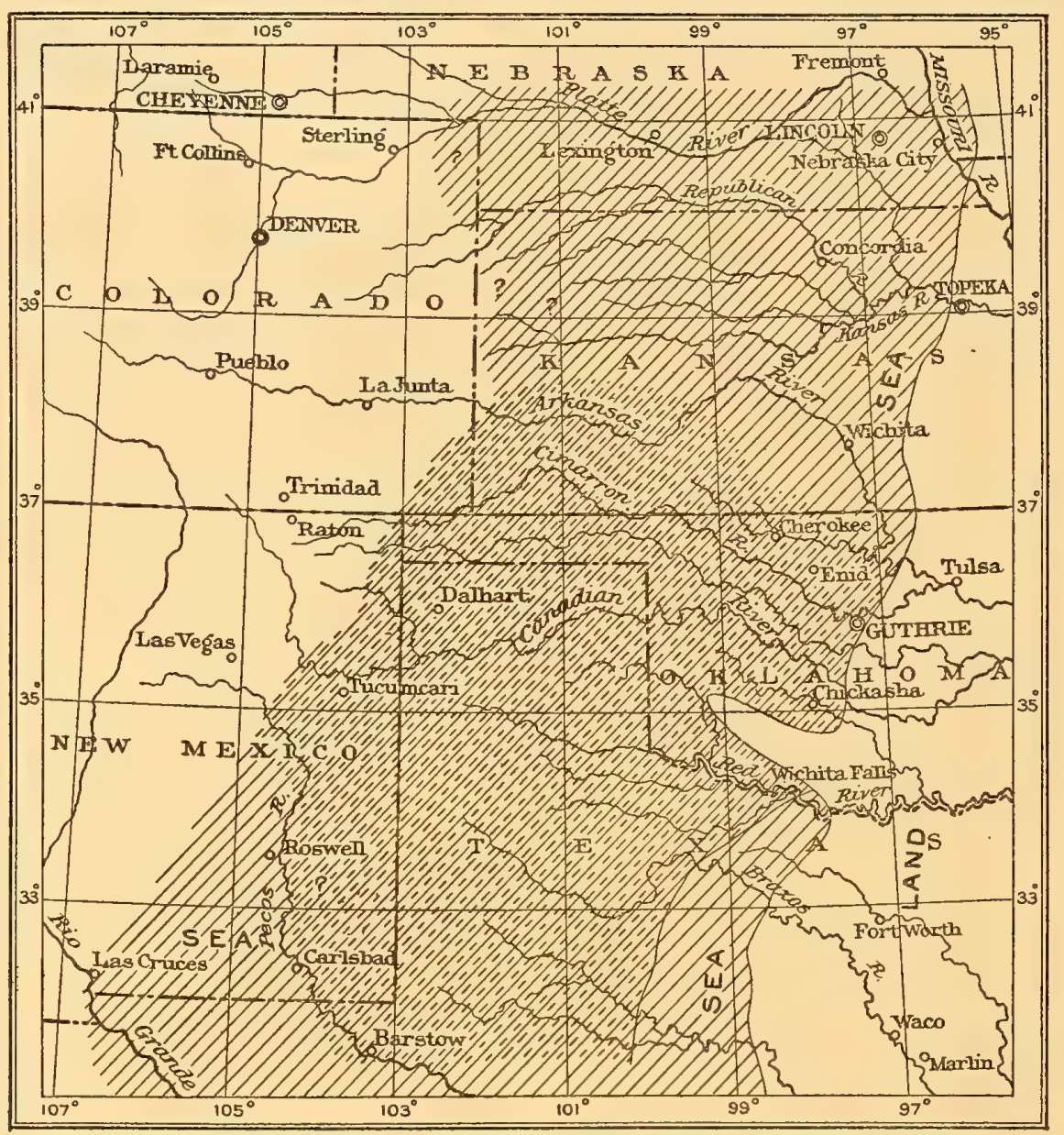

FIG. 3.-Map showing Beede's idea on the paleogeography of red beds in the southern part of the Plains Province (after Beede).

In his Review of the Geology of Texas, Udden ${ }^{1}$ describes the formations concerned as follows:

\footnotetext{
"Delaware Mountain Formation.
}

"This formation is composed of an alternation of gray and bluish limestone with white and brown sandstone. At the lower part is a blue-black thin-bedded limestone, shaly in part. The base is not exposed. Toward the north of the Delaware Mountains the formation becomes more sandy; toward the south the limestone increases in amount. In the Apache Mountains the formations consist entirely of massive whitish-gray limestone. As the base of the formation is unknown, the entire thickness can not be determined, but is at least 2,200 feet. The Delaware formation forms a broad zone composing the Delaware, the

${ }^{1}$ Udden, J. A., Bull. University of Texas No. 44, p. 54, I9I6. 
Apache Mountains, the lower part of the Guadalupe Mountains, and part of the Wylie Mountains. It extends into New Mexico.

\author{
"Capitan Limestone.
}

"This formation is composed of a massive white limestone remarkably homogeneous in appearance. The entire thickness can not be determined, but it is at least $\mathrm{I}, 700$ feet. It is known only in the Guadalupe Mountains and extends far into New Mexico.

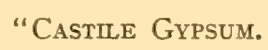

"Castile Gypsum.

"This formation is in great part composed of a massive, white, granular gypsum, but interbedded with it are thin beds of gray and yellow limestone and dolomite, as well as thicker beds of the same rock and considerable masses of gray, red, and green shales and marls. The thickness of this formation is not exactly known, but two deep wells near Rustler Springs show that it can not be less than I,000 feet. The Castile gypsum forms a band about I 5 miles broad, west of the hills composed of the Rustler limestone; toward the north the Castile gypsum is found also east of the Rustler Hills, so that the breadth of the zone increases to about 30 miles near the boundary of New Mexico. Some isolated exposures are found on the west side of the Delaware Mountains. As far as known, the Castile gypsum rests everywhere unconformably on the Delaware formation. Some shale in this formation is sulphur-bearing in Culberson County.

$$
\text { "Rustler Formation. }
$$

"Compact, fine-textured, gray dolomitic limestone and dolomite, generally quite heavy-bedded, compose this formation. At the base there is in most places a considerable mass of light pink or yellowish brecciated limestone. In the northern part of the region some yellow sandstone alternating with limestone is developed below the brecciated limestone. The thickness of the Rustler formation has not been determined, but it must be at least several hundred feet. The Rustler formation appears in a series of low hills extending from a point about I2 miles north of Kent to the boundary of New Mexico."

It has been shown by $\mathrm{Case}^{1}$ that the red beds of upper Permian age in western Texas do not extend across eastern New Mexico in the latitude of Tucumcari and Las Vegas, and he has pointed out that the beds of Texas and New Mexico that far north are parts of distinct provinces, a fact borne out by his discovery of vertebrates similar to those occurring in Rio Arriba County, New Mexico, near Socorro. It would, then, appear that the beds of western Oklahoma (Whitehorse) are in reality above the Capitan limestone. The difference in stratigraphic position, however, need not be alarming, as in such beds the rate of accumulation might be at times exceedingly rapid.

The suggestion of Beede that the elevation and erosion of the Delaware and Capitan limestones was an occurrence quite similar to that occurring in eastern central and eastern North America in the same general time interval is very pertinent here.

${ }^{1}$ Case, E. C., The Red Beds Between Wichita Falls, Texas, and Las Vegas, New Mexico, in Relation to Their Vertebrate Fauna, Jour. Geol., vol. XxII, p. 243, I9I4; Carnegie Inst. Wash. Pub. 207, p. 6I, I9I5. 
Descriptions are given by Udden ${ }^{2}$ of the beds of certain deposits of Permo-Carboniferous age in Trans-Pecos Texas:

“The Shafter Region, Presidio County.

"THE CIBOLO BEDS.

"The rocks which represent the Permian have been called by Udden the Cibolo beds, and they have been subdivided by the same author from below to above in: Transition beds, Lower Brecciated Zone, Zone of Sponge Spicules, Thin-bedded Zone, and Yellow Limestone.

"Transition Beds.-Gray marly shale with lenticular ledges of organic and siliceous sand. Their thickness is about roo feet.

"Lower Brecciated Zone.-Grayish-white limestone in heavy ledges often thoroughly brecciated. The thickness is about I 33 feet.

"Zone of Sponge Spicules.-In the lower part, this consists of thinner-bedded limestone. Above it becomes siliceous and changes into pure sandstone. The thickness of this bed is 85 feet.

"Thin-bedded Zone.-Dark, evenly bedded and compact limestone, including some sandy strata. The limestone contains cherty material which weathers out in rusty edges of plates of irregular shape, or porous spherical shells and nodules. Much of the rock is bedded in uniformly thin ledges; occasionally the ledges thicken lenticularly. Thickness, about 470 feet.

"Yellow Limestone.-Hard, yellow, siliceous, and dolomitic limestone, showing bedding planes only in the lower part, while higher up the stratification becomes indistinct. Thickness, about 650 feet.

"This series has been observed on Cibolo Creek near the Chinati Mountains west of Shafter.

\footnotetext{
"The Marathon Region.
}

"The Permian is very well developed in the Glass Mountains. It has been subdivided by Udden in four formations, which are, from below to above, the Leonard, Word, Vidrio, and Gilliam. The lower formations are found in the southern and southeastern hills, while the upper ones-the Vidrio and Gilliam formations-occupy the center and the whole northern slope. Towards the southwest the continuation of this Permian is found in the Altuda Mountain and south of it, in the Ord Mountain Range. Toward the north we find an isolated outlier in the Sierra Madre. The highest parts of the Permian are covered unconformably by the Comanchean Cretaceous. $* * *$.

\section{"WORD FORMATION}

"In the upper part this is composed of thin- and thick-bedded gray and yellow to reddish limestone, in part dolomitic, containing chert concretions with some interbedded strata of sandstone (about 380 feet); below this we find some I 20 feet of yellow sandstone, in part laminated. The lowest part of this formation consists of I2O feet of heavy-bedded gray limestone, with chert concretions. The entire thickness of this formation is approximately 600 feet.

$$
\text { "vIDRIO FORMATION. }
$$

"This series is composed of a very uniform, dark to light gray, dolomitic limestone, or dolomite, with very few layers of pure limestone. The dolomite

${ }^{2}$ Udden, J. A., Review of the Geology of Texas, Bull. University of Texas No. 44, p. 50, I9I6. 
contains considerable chert in irregular form. In the uppermost part we find one or two beds of reddish-brown sandstone about 4 feet thick. The entire thickness of this formation is about 2,000 feet.

"GILliam FORMATION.

"This series is composed of gray, light-colored, and reddish limestone and dolomite; both are frequently brecciated. In the upper part the rock is nearly massive, or, at least, bedding planes are very dim. In the middle the limestone shows thick lenticular beds, while in the lower part it is decidedly thin-bedded. At the base we find thicker layers of reddish dolomite alternating with thinly laminated layers of the same rock and with thin strata of yellowish marly sandstone. The thickness of this enormous mass is 2,500 feet, in Gilliam Canyon."

The Permo-Carboniferous appears in other localities near Ord Mountain, but the general character of the deposits are the same as those already described. (See page 53 of Udden's report.)

Correlation table of the Texas Permian.

From Udden's Report, page 56.

\begin{tabular}{|c|c|c|c|}
\hline Shafter region. & $\begin{array}{l}\text { Ord Mountain and } \\
\text { vicinity. }\end{array}$ & Glass Mountains. & $\begin{array}{c}\text { Delaware-Guadalupe } \\
\text { Mountains. }\end{array}$ \\
\hline \multirow{2}{*}{ Yellow limestone. } & I. Vidrio formation. & $\begin{array}{l}\text { Gilliam formation. } \\
\text { Vidrio formation. }\end{array}$ & \multirow{3}{*}{$\begin{array}{ll}\begin{array}{c}\text { Rustler } \\
\text { limestone. }\end{array} & \text { Capitan } \\
\begin{array}{l}\text { Castile } \\
\text { gypsum. }\end{array} & \begin{array}{l}\text { Delaware } \\
\text { formation. }\end{array} \\
& \end{array}$} \\
\hline & $\begin{array}{l}\text { 2. Sandstones and lime- } \\
\text { stones. }\end{array}$ & Word formation. & \\
\hline \multirow{2}{*}{$\begin{array}{l}\text { Thin-bedded zone, } \\
\text { Zone of sponge spicules, } \\
\text { Lower brecciated zone. } \\
\text { Transition beds. }\end{array}$} & $\begin{array}{c}\text { 3. Shales, sandstones } \\
\text { and limestones. }\end{array}$ & & \\
\hline & $\begin{array}{l}\text { 4. Limestone conglomer- } \\
\text { ate and thin-bedded } \\
\text { or flaggy limestone. }\end{array}$ & Leonard formation. & \multirow[t]{2}{*}{ Hueco formation. } \\
\hline $\begin{array}{l}\text { Pennsylvanian (Alta and } \\
\text { and Cieneguita beds). }\end{array}$ & Pennsylvanian. & Gaptank formation. & \\
\hline
\end{tabular}

Two papers in the University of Texas Bulletin ${ }^{1}$ give additional information concerning the late Paleozoic deposits of the western part of Texas. Udden adds three formations to the list quoted above. His series in the Glass Mountains is as follows:

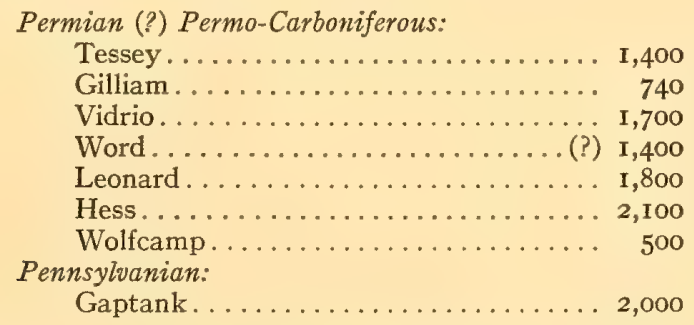

${ }^{1}$ Udden, J. A., Notes on the geology of the Glass Mountains, Univ, Texas Bull., No. I753, 1917.

Baker, C. L., and W. F. Bowman, Geologic exploration of the southeastern Front Range of Trans-Pecos Texas. Idem. 
"The Wolfcamp consists mostly of shales which vary in color from almost black to gray and greenish-gray. Interbedded with this shale are several layers of limestones which are cemented shell breccias, in places conglomeratic. There are also layers of calcareous sandstones." There is possible an unconformity between the Gaptank and the Wolfcamp, and the fauna of cephalopods in the upper formation indicates a decided break in the sequence of life between the two.

The Hess formation consists of limestones, largely oolitic, shales, sandstones and a minor amount of conglomerate. "The color of this limestone is mostly light gray. The individual beds have a uniform development and can be traced for comparatively long distances. It can also be said that the general aspect of these limestones resembles that of the Hueco formation farther west in the State, but sufficient collections of fossils have not been made from this formation for the purpose of verifying such a correlation. In its upper part, fossils are quite plentiful in certain layers. It appears that the dolomitization of the limestones in this formation has proceeded at quite unequal rates in different places. At the west end of the escarpment, dolomitization is quite general. As we go away from the disturbance near the igneous intrusions extending northeast from the Iron Mountain, dolomitic layers appear less frequently than at the west end. The sandstones and shales of this formation are present mostly in the lower four hundred feet. Most of the shale is bluish-light gray in color. The sandstones are usually free from limy material, have an open texture, and are moderately fine grained. In places they show cross-bedding. The basal conglomerate of the Hess consists mostly of limestone boulders, but it also contains some boulders of flint and other quartz. All the underlying formations are represented. It varies from ten to forty feet in thickness." The Hess is separated from the Wolfcamp and Gaptank by a considerable unconformity. In his paper Udden says: "It is believed that the Leonard is to be correlated with the Clear Fork in the west-central part of the State. Perhaps it includes also the basal part of the Double Mountain, and the upper part of the Albany limestones. It certainly also contains many of the forms noted in the Delaware formation of Girty." He further says: "Apparently there is no doubt that the Word formation belongs to the Delaware deposits of Girty in the Guadalupe Mountains. It also represents the main part of the Double Mountain in central Texas."

The Tessey formation is composed mostly of unstratified dolomite resembling the Vidrio. "It is believed that the Vidrio, the Gilliam and the Tessey formations are in part the equivalents of the Capitan limestone in the Guadalupe Mountains. Together they have a thickness of 3,800 feet, which is more than twice the known thickness of the Capitan limestone. The three formations are conformable and dip to the northwest with an angle of about eight degrees." 
Baker and Bowen, describing the Front Range west of the Glass Mountains, say that after the Gaptank was deposited the sea "withdrew from the region, subaerial erosion followed, and a resubmergence brought about the deposition of some 8,000 feet of Permo-Carboniferous sediments. This epoch of marine deposition was twice interrupted by uplift which brought about renewed erosion, as is indicated by two unconformities and basal conglomerates in the Permo-Carboniferous series."

Both of these papers give detailed accounts and sections with lists of fossils showing the marine conditions in the Trans-Pecos Texas region during what the authors call the Permian (?) or Permo-Carboniferous time. In the opinion of the author of this paper the correlation of the Leonard with the Clear Fork and the Word with the Double Mountain must await more proof than is contained in Udden's paper. There is the possibility that they were formed in the same interval of time, or the Clear Fork and Double Mountain may have been formed in the long period represented by the erosion interval described by Baker and Bowen between the Gaptank and the series of limestones above it.

\section{THE LATE PALEOZOIC IN THE NORTHERN PART OF THE PLAINS PROVINCE AND ON THE EASTERN FRONT OF THE ROCKY MOUNTAINS.}

On page 62 of Publication 207 of the Carnegie Institution the author has given a résumé of the general lie of the Permo-Carboniferous Red Beds. As was shown in that publication, there is a merging of limestone into red shales and sandstones in the northwestern portion of the Plains Province similar to the merging which occurs in Kansas, Oklahoma, and Texas.

The red beds in the North and on the slopes of the eastern face of the Rocky Mountains have never been placed exactly in the geological column. This is in part due to the lack of determinant fossils and in part due to the conditions of deposition, terrestrial deposition prevailing and producing overlapping and interlocking lenses of relatively small areal extent. Moreover, there is little doubt that the "red beds conditions" extended in time from late Pennsylvanian into, if not through, Triassic time. It is, so far, impossible to correlate any of these beds with the more definitely determined beds in Oklahoma or Texas, but there is no question that at approximately equivalent intervals of time similar results were produced on the borders, at least, of the Plains Province by similar conditions.

The age of the red sandstone and shale has been variously reported by different authors. A portion of the discussion quoted in Publication No. 207 of the Carnegie Institution is repeated here to show the attitude of various writers:

"In Professional Paper 32, United States Geological Survey, Darton discusses the character of the Red Beds of the Front Range of the Rocky Mountains. The 
upper Carboniferous limestone is found in the northern part of the Front Range near the Wyoming line and in the Culebra Range it appears to merge into the Fountain Red Beds, which he believes to be the exact equivalent of the Lower Wyoming of Eldridge and the Badito of Hills, and to represent the Amsden formation and overlying Tensleep sandstone of the Bighorn Mountains and the Minnelusa formation of the Black Hills. The lower Red Beds of the Rocky Mountain Front Range have yielded no fossils, but undoubtedly merge into limestones both on the north and the south and can be correlated with formations in the Black Hills and the Bighorn Mountains. Darton says further:

"'Throughout the Black Hills, the Bighorns, and much of the region to the south the upper Carboniferous and Red Bed series presents a general succession as follows, beginning at the top: A thick mass of gypsiferous, red, sandy shales; a thin mass of thin-bedded limestone; a thin mass of red sandy shales; a thick, hard, light-colored, fine-grained sandstone; and, at the base, limestones and sandstones giving place to sandstones and conglomerates, the basal series lying unconformably upon the Mississippian limestones, on Cambrian, or on old granites and schist.

" Near the Colorado-Wyoming State line the upper Carboniferous limestone may be seen to merge into red sandstones, apparently by the expansion of included reddish sandy layers observed northwest of Cheyenne and a corresponding thinning of the limestones. A mass of red sandstones and conglomerates, which lies at the base of the limestones for some distance, is seen also to thicken gradually to the south.

" "The name "Fountain formation" has been used to comprise all of the red beds in the region northeast of Canyon and southwest of Pueblo, and if, as I believe, the Chugwater (upper Wyoming) formation thins out a short distance south of the Garden of the Gods, the Fountain formation corresponds in the main to the lower Wyoming, and is the product of similar conditions at the same geological epoch. I do not see the slightest reason for supposing that the two formations are not equivalent.

"The character of the beds northwest of Pueblo and in the Garden of the Gods region is precisely the same as in the district west and north of Denver, and although I made special search I could find no evidence of overlaps or unconformities of any kind within the great uniform mass of red grit deposits.

"'The upper and lower Wyoming are very distinct from each other from the Garden of the Gods north to the State line, as recognized by the geologists of the Hayden survey and clearly set forth in the Denver monograph, where the terms "lower Wyoming" and "upper Wyoming" were introduced. The upper Wyoming consists mainly of fine-grained sediments extending from the "creamy sandstone," which I believe to be the equivalent of the Tensleep, to the base of the Morrison formation. It consists mainly of bright-red shales, always with a thin limestone layer or series toward its base, and from Platte Canyon northward with a massive pinkish sandstone at its top. The included limestone is believed to represent the Minnekahta horizon of the Black Hills and other regions, indicating a short but widespread interval of limestone deposition at this epoch in the West. The few fossils found in this limestone unfortunately do not settle its age, but there appears to be but little doubt that its representative in the Black Hills is Permian. The overlying red shales, with gypsum, in northern Colorado may be Permian or Triassic, for the fossils in the limestones which occur near the top of the extension of this series into the Bighorn uplift do not indicate whether the beds are Paleozoic or Mesozoic. 
"The Chugwater formation (upper Wyoming Red Beds) is only I40 feet thick at the Garden of the Gods and appears to thin out and disappear a few miles south, bringing the Fountain formation into contact with the Morrison, a relation due either to non-deposition of the Chugwater beds or to their removal by erosion in pre-Morrison times. As it is, the hiatus probably represents part of the later Carboniferous, the Permian, the Triassic, and all of the Jurassic periods. South of the Arkansas River some of the Chugwater beds probably appear again, although at present their identity is not established.

" "The Badito formation of Hills appears to be simply the Fountain formation of Cross and Gilbert. The Sangre de Cristo formation to which Hills refers in the Walsenburg folio appears to represent a great development of Fountain (or lower Wyoming) deposits. It is stated that remains of an upper Carboniferous fauna and flora occur in this formation, which is added evidence as to the age of the lower Red Beds (Fountain-lower Wyoming) series. These beds overlie or merge into the basal limestone series on the eastern slope of the Sangre de Cristo (Culebra) Range, in which Mr. Willis T. Lee has discovered an extensive upper Carboniferous (Pennsylvanian) fauna.

"The red beds revealed in the canyons of the southeastern Colorado can not be classified with certainty from the present evidence. On Purgatory River and Muddy Creek the principal body of red beds is separated from the Morrison formation by gypsum or gypsiferous shales, strongly suggestive of the Chugwater (upper Wyoming) formation. It was immediately under this gypsum in Purgatory Canyon that I found the shoulder bone of a supposed belodont. Mr. Willis T. Lee has traced the Red Beds farther south into northeast New Mexico, where the gypsiferous horizon gives place to a massive sandstone, termed the Exeter sandstone, constituting the summit of the Red Beds, a member which may represent the distinctive top sandstone of the Chugwater formation in northern Colorado and in southern Wyoming. The sandstone is prominent in the Two Buttes uplift, constituting the summit of the Red Beds, and is underlain by red shales, which contain a thin bed of limestone, noted by Mr. Gilbert, strikingly like the Minnekahta horizon. I have not made observations on the Red Beds in Kansas and do not feel that a comparison of the published statements with my observations in the region north and west should aid in the correlation.'

"Girty regards the Fountain formation as Pennsylvanian. Henderson" regarded the lower part as Mississippian and the upper as Pennsylvanian, and David White, ${ }^{3}$ from the evidence of fossil plants, would place it in Pottsville time.

"In Professional Paper 53, United States Geological Survey, Darton speaks of the Red Beds of Colorado. He says that in southern Colorado the Red Beds lie on an irregular surface of granite, except in certain embayments, as the ones at Manitou and Canyon City, where lower Paleozoic rocks intervene. The Red Beds have been found to be an extension of the Red Beds underlying the Carboniferous limestone in southeastern Wyoming and of the Permian and overlying Red Beds of Kansas. ${ }^{4}$ The Red Beds of this region he considers divisible into three parts: (I) the Fountain or lower Wyoming (the lowest), consisting of coarse red grits which he found to represent the upper Carboniferous limestone of

${ }^{1}$ Girty, U. S. Geological Survey, Professional Paper No. 71, pp. 369-37o.

2 Henderson, Jour. Geol., vol. I6, pp. 49I-492, I 908.

${ }^{3}$ White, David, U. S. Geological Survey, Professional Paper No. 7 I, p. 370.

1 The Red Beds of Kansas have since been shown to be continuous, in part at least, with the Permian limestones and not to overlie them.-E. C. CASE. 
Wyoming; (2) the Tensleep sandstone, traced as far south as the Manitou embayment; (3) the gypsiferous red shale and sandstone of the Chugwater, which represents the red beds of the Black Hills and Wyoming. The lower part of the Chugwater he considers as Permian, the upper part as Triassic or Permian.

"Henderson" in 1908 gave an account of the Permo-Triassic (?) of the foothills formations of northern Colorado. He distinguishes the upper part of the Wyoming as partly Permian.

" 'Lykins formation.-Conformably overlying the Lyons is a series of variegated, mostly thin-bedded sandstones and shales, rather friable, chiefly deep red in color, with thin limestone bands, the upper part usually gypsiferous. In the Boulder district Fenneman names these beds the Lykins formation. It is the exact equivalent of the upper Wyoming of Emmons in the Denver Basin and the Chugwater of Darton in northern Colorado. In the Denver Basin monograph it is given a thickness of 485 to 585 feet; Fenneman makes it 800 feet in Four-mile Canyon, north of Boulder, and Darton gives it a thickness of 380 feet at Lyons and $\mathbf{5 2 0}$ feet at Owl Canyon. Though it varies greatly in thickness and in stratigraphic details, its general characters are constant throughout the region. As a whole the formation is non-resistant, the greater part being concealed by the debris in the lateral north-south valleys caused by its destruction.

"From Owl Canyon to the Little Thompson I have mapped as part of the Lykins a more resistant sandstone, strongly cross-bedded, which forms a ridge in the valley and which sometimes extends nearly to the top of the east slope of the Lyons escarpment. It is difficult to distinguish from the Lyons sandstone, and should perhaps be assigned to that formation, but is uniformly separated from the latter everywhere north of the Little Thompson by strata lithologically resembling the Lykins. In approaching Little Thompson Canyon these intervening beds rapidly play out, bringing the sandstone which is mapped as Lykins into contact with the Lyons and making the former the crest of the escarpment, almost covering the latter. Thence southward it is doubtful if the two sandstones can be recognized as distinct formations, and nowhere have I found a noticeable unconformity. As the two sandstones after coalescing form an almost vertical escarpment, if they are distinct it is practically impossible to represent the Lyons on the map, yet northward they are quite distinct. The one which is mapped as Lykins in the northern region passes beneath the "crinkled" sandstone of Fenneman's report, which is but a few feet above the Lyons north of Boulder. This problem is worthy of future investigation.

" "In some places certain strata of the Lykins are very massive, though soft, and portions of the formation are locally calcareous, in addition to distinct limestone bands.

"'In the absence of paleontological evidence this formation has been usually assigned to Triassic-Jurassic age. It seems quite likely, however, that the base of the Lykins may represent Permian time, as the immediately underlying Lyons is upper Carboniferous. The upper part of the Lykins is probably Triassic or Jurassic, as it is overlaid by known Jurassic in northern Colorado, though it is possible that part of the Jurassic and Triassic is represented by the general unconformity between the Lykins and the Morrison.'

"Butters" in I9I 3 gave a very detailed account of the 'Permo-Carboniferous'

${ }^{1}$ Henderson, First Annual Report Geological Survey of Colorado, p. I68, I908.

2 Butters, R. M., Permian or Permo-Carboniferous of the Eastern Foothills of the Rocky Mountains in Colorado, Colorado Geological Survey, Bull. 5, pt. 2, p. 65, 1913. 
of the eastern foot-hills of the Rocky Mountains in Colorado. After detailing the conditions in the various sections from the north line of Colorado south he says:

"Overlying this (the Ingleside) is the Lykins formation, and at one horizon about 200 feet from the base, at Heygood and Box Elder Canyons, Bellerophon crassus and Myalina subquadrata were found. The same species are found in the Fountain and Ingleside below. On this evidence, together with the fact that there is no angular unconformity, and no marked difference of lithological character, this basal portion of the Lykins is assigned to the Pennsylvanian period. On the northern slope of Table Mountain, Larimer County, 40 to 50 feet higher than the fossiliferous stratum, and separated from it by a gypsiferous series, another fossiliferous stratum occurs. This is probably more than 300 feet from the top of the Lykins formation and seems to be in the same stratigraphic position as the fossiliferous beds near Stout, and also those in the crinkled sandstone near Perry Park. At Stout, and also at Table Mountain, the "crinkly" structure is not present."

" Correlations. - The correlation of the Fountain, Ingleside, Lyons, and Lykins along the foothills from the line to Colorado Springs is a question of recognizing the same formation under different names. $* * *$ Thus the Fountain of Fenneman in the Boulder quadrangle is equivalent to the lower part of the Fountain of Cross in the Pikes Peak area. The Fountain, Ingleside, and Lyons together are equivalent to the lower Wyoming of the Denver Basin area. The Lykins is equivalent to the Chugwater of Darton and the upper Wyoming of Emmons. The upper portion of the Fountain and the Ingleside together are equivalent to Darton's Casper formation. The Lyons is equivalent to the Creamy sandstone of the Denver Basin area, but Darton's Tensleep is not the equivalent of the Lyons and the Creamy sandstone. It is a lower horizon, and can be correlated only with the lower portion of the Lyons, and also the Ingleside. An explanation of this requires a description of the conditions in northern Colorado. This has been made under "Formation names." Darton's Tensleep in Colorado is probably in part equivalent to the sandstone-limestone series; that is, the Ingleside series.

" Owing to the absence of fossil evidence in the Badito formation, and from the fact that it is separated so widely from any recognized Fountain exposures, it has not been definitely correlated with the Fountain. Lithologically they are very similar, and the Badito overlies pre-Cambrian rocks unconformably, bearing about the same relation to the overlying formations as does the Fountain. On these grounds they are at least approximately in the same horizon.

"The Cutler formation is defined as that portion of the "Red Beds" lying above the Rico, where that is present, or otherwise as succeeding the Hermosa and below the Dolores. The Cutler is assigned to the Permian purely on stratigraphic grounds, and is separated from the Rico by a purely arbitrary line. There seems to be as good ground for assigning the Lykins, above the crinkled sandstone, or at least the lower portion of it, to the Permian, and thus correlating it with the Cutler.

" "Above the Cutler formation in the San Juan region is a series of sandstones, sandy shales, and conglomerates which vary in thickness from 800 to 400 feet, and from that down to 30 feet at the San Miguel River, disappearing entirely north of this river. These shales and sandstones are a bright vermilion in color, and are known as the Dolores formation. They are assigned to the Triassic age because of the scanty, but widespread, vertebrate, invertebrate, and plant remains. The extreme upper part of the Lykins in Larimer County may be equivalent to the Dolores and thus be Triassic. If so, it is impossible to draw a line between the Permian and Triassic in eastern Colorado.'” 


\section{CHAPTER IV.}

\section{THE BASIN PROVINCE.}

\section{A. THE UPPER PENNSYLVANIAN IN THE BASIN PROVINCE.}

Though the distinction between the Permo-Carboniferous red beds of the Plains and Basin Provinces is clearly marked, there is strong evidence that the Pennsylvanian limestone which forms their base is continuous at least across the southern end of the barrier which divided them. (Fig. 4.) There has been a very general consensus of opinion that the Hueco limestone of the Guadalupe Mountains is equivalent to the Kaibab of the Grand Canyon region and connects through that limestone with a series of deposits. which extend through the basin province as far north as Alaska and that the fauna of the whole horizon places it as equivalent to the Russian Gschelian; but for a recent expression of a different opinion see the summary of a paper by Schuchert on page I52. Girty says: ${ }^{1}$

"The Hueconian fauna is widely distributed over the West, ranging indeed into Alaska, while it is even recognizable in Asia and eastern Europe. Most of the occurrences of Carboniferous in the West can be referred to this series, although some of them present more or less distinctive facies. The more important of the facies provisionally referred to the Hueconian are these: that of the Aubrey group of Arizona, rather widely distributed; that of the phosphate beds of the Preuss formation [Park City formation], local in Utah, Idaho, and Wyoming; the Spiriferina pulchra fauna with a considerable distribution in Idaho, Wyoming, Utah, and Arizona; the fauna of the McCloud limestone of California probably extending into Nevada; and that of the Nosoni formation of California (in part of the 'McCloud shale'), apparently recognizable to the eastward and to the North and West, even into Alaska." A little further on in the same paper Girty says that "The Gschelian is clearly related to our Hueconian."

Further remarks by Girty in the same paper ${ }^{2}$ make it apparent that he is far from assuming a definite position with regard to the equivalency of the Russian and American beds:

"I am tentatively assuming, on the grounds noted above, that the Guadalupian is equivalent to the Permian or to the Permian and Artinskian, the one representing a normal marine and the other an abnormal facies. It may prove, however, that all or part of the Guadalupian is younger than the Permian. *** In view of the striking difference between the faunas of the Guadalupian and the

${ }^{1}$ Girty, Geo. H., Outlines of Geologic History, p. I30, I9Io.

2 Loc. cit., p. 133 . 
Hueco formation, in which the brachiopods are most in point, of a lack of a corresponding difference between the Gschelian and Permian, of the marked resemblance of the brachiopods of the Hueco and Gschelian, and of the lack of agreement between the Permian and Guadalupian, there is a possibility, if not a certain probability, that the Artinsk and Permian may be correlated with the Hueco formation."

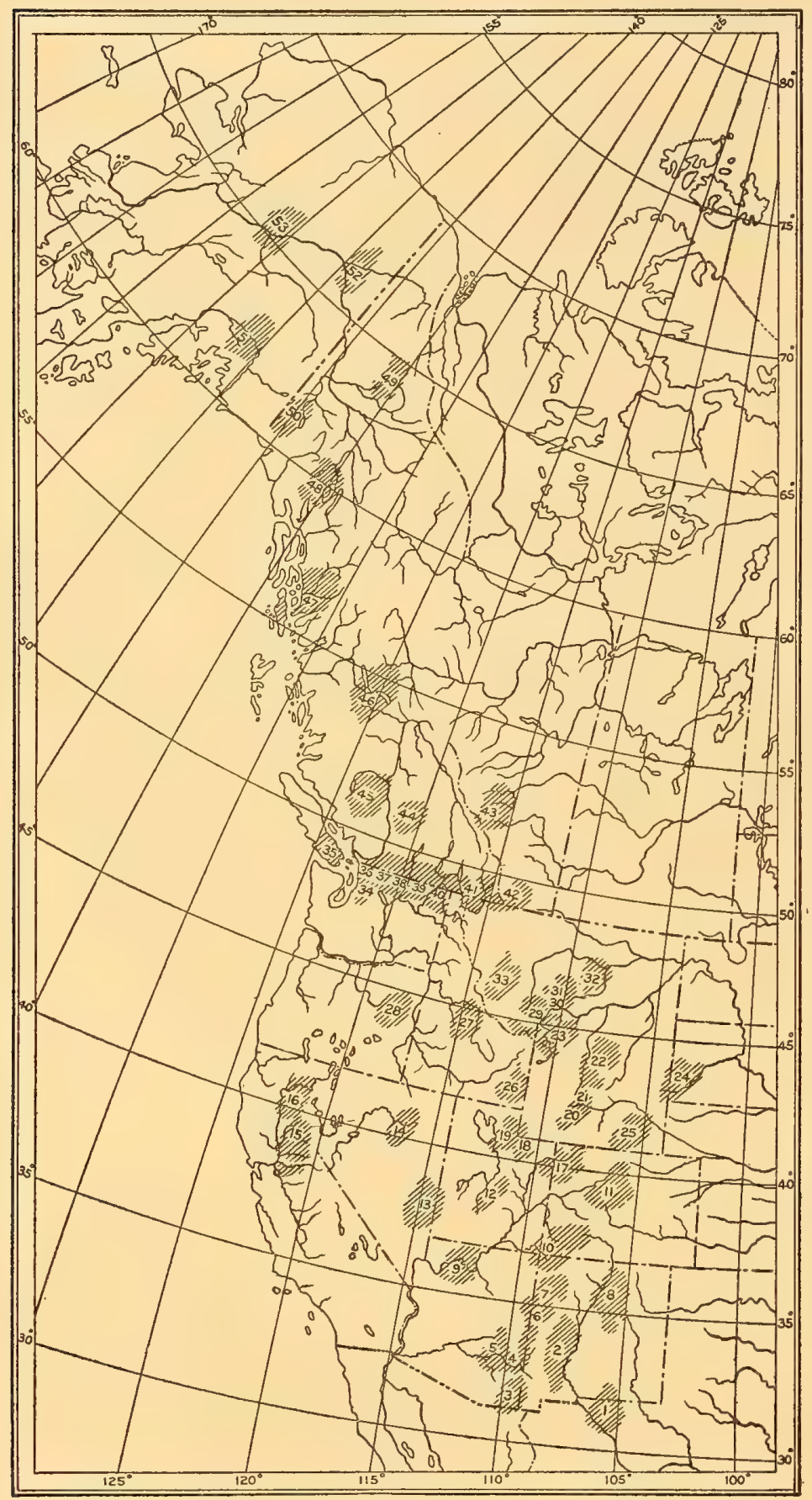

FIG. 4.-Key map giving location of areas of late Pennsylvanian deposits in the Basin Province discussed in this work.
I. Guadalupian area.

2. Southern and central New Mexico.

3. Bisbee, Arizona.

4. Clifton-Morenci, Arizona.

5. Globe, Arizona.

6. Ojo Caliente, New Mexico.

7. Zuñi Uplift, New Mexico.

8. Manzano area, New Mexico.

9. Grand Canyon, Arizona.

ro. San Juan area, Colorado.

II. Ten Mile quadrangle, Colorado.

I2. Canyon Range, Utah.

13. Eureka, Nevada.

4. Battle Mountain, Nevada.

15. Sierra Nevada, California.

16. Klamath, Redding, California

17. Uintah Mountains.

18. Wasatch Mountains.

19. Park City district, Utah.

20. Wind River Mountains, Wyoming.

2I. Owl Creek Mountains, Wyoming.

2. Big Horn Mountains, Wyoming.

23. Yellowstone National Park.

Black Hills, South Dakota.

25. Laramie Mountains, Wyoming.

6. Phosphate area, Idaho.

27. Wood River area, Idaho.

28. Eastern Oregon.

20. Three Forks, Montana

30. Little Belt Mountains, Montana.

3r. Fort Benton, Montana.

32. Big Snowy Mountains, Montana.

33. Phillipsburg, Montana.

34. Republic area, Washington.

35. Duncan map area, Vancouver Island.

36. Skagit Range, British Columbia.

37. Hozomeen Range, British Columbia.

38. Okanagon Range, British Colum-

39. Midway Mountains and Anarchist Plateau, British Columbia.

40. Rossland, Pend d'Oreille, Selkirks, and Columbia system west of Christiana Lake, British Columbia.

4r. Flathead Valley, British Columbia. 42. Blairmore, Alberta.

43. Banff, Alberta.

44. Highland Valley and Thompson River, near Kamloops, British Columbia.

45. Bridge River and Chilkas Lake, British Columbia.

46. Stewart and Tacla Lakes, British Columbia.

47. Ketchikan and Wrangell district, Alaska.

48. Lake Tagish, British Columbia 49. Peale and Stewart Rivers, Yukon. 50. Headwaters of White River, Chisana and Nabesna Rivers, Yukon.

5I. Headwaters of Copper and Susitna Rivers, Gulkana River, Alaska. 52. Upper Yukon and Porcupine Rivers, Alaska.

53. Upper Yukon and Fairbanks quadrangle, Alaska. 
Despite this uncertainty expressed by Girty, there seems to be a very definite opinion in the minds of most workers in this region that the fauna and horizon equivalent to the Hueconian west of the Rocky Mountain barrier is Gschelian in age.

Beede $^{1}$ has expressed the opinion that the Delaware limestone is upper Pennsylvanian and that the Hueco is Mississippian in large part. This opinion is frequently expressed by Girty himself, in other papers.

Though the Hueco and its equivalents occupy a position considerably below the top of the Pennsylvanian, they afford a very convenient base from which to reckon the changes which occur in upper Pennsylvanian and Permo-Carboniferous time, and for this reason is traced in considerable detail in the following pages. Except in the Guadalupe Mountains and the regions far north in the United States, western and northwestern British Columbia, and in Alaska, this limestone horizon is followed by shale and sandstone beds which lead up to red beds or their chronological or conditional equivalents. In the Guadalupe Mountains such a transition is lacking, the Delaware limestone following the Hueco limestone directly; in the other regions cited, the red beds and the transition beds, if ever present, have been wholly or in part removed by erosion.

(a) Conditions in Texas.-Udden states of the Huecolimestone formation that it-

"consists almost entirely of a gray, hard, thick to thin-bedded limestone, which contains very little magnesia, or none at all. At the base of this limestone generally occur yellow to brown and purple sandstones, and conglomerates, as well as some gray and yellowish shales. The entire formation is at least 5,000 feet thick." 2

It occurs pretty widely through Trans-Pecos, Texas, outcropping in the various uplifts; the southern limit is unknown. South and southwest of the Guadalupe Mountains in the Shafter region, Presidio County, the Cieneguita beds consist of-

"dark to black shales alternating with dark limestones, conglomerates, and heavy lenticular masses of a clastic rock composed of siliceous fragments cemented by calcareous clay (mortar rock). The shale predominates. Locally, some layers of black chert occur. This whole series of rocks is at least I, ooo feet thick." ****

"The Alta beds, which rest on the Cieneguita beds, show a thickness of about 3,500 feet. They consist of some dark shales below and some yellow sands above.

"The dark shales consist of sharply bedded layers of silt, clay, and some sand, with layers of coarser and more purely sandy material. The thickness of this series is approximately 2,000 feet.

"The yellow sand consists of a soft, occasionally almost crumbling, bluishgray sandstone of fine texture. It is a coarse silt of well-assorted quartz grains. The thickness of this series is about $I, 500$ feet."

${ }^{1}$ Beede, J. W., The Correlation of the Guadalupian and Kansas Sections, Amer. Jour. Sci., vol. XXX, P. I3I, I9I0. See his figure reproduced as figure 2 of this paper.

2 Udden, J. A., Review of the Geology of Texas, Bull. 44, University of Texas, p. 48, I9I6. 
In northern Brewster and southern Pecos Counties is a series of upper Pennsylvanian rocks called Gaptank by Udden. ${ }^{1}$

"It consists at the base of conglomerates alternating with limestones, sandstones, and shales; in the middle part of shales interbedded with limestone; while the upper portion is mainly composed of several masses of limestone separated by shaly and sandy material. The thickness of the whole formation surpasses $I, 500$ feet. It probably corresponds to the highest portion of the Pennsylvanian of central Texas-the Cisco formation."

The Leonard formation is regarded by Udden $^{2}$ as Permian, but seems more properly to belong with the Pennsylvanian series. Udden describes it as follows:

"The upper part is composed of thinly laminated yellowish sandstone interbedded with layers of gray limestone, yellow chert, and gray shales.

"The lower part consists of heavy and thinly bedded gray limestone, in part conglomeratic or containing pebbles of different size. At the base, shales and soft sandstones are interbedded with a dark gray limestone. The thickness of the entire series is nearly $\mathrm{I}, 800$ feet.

"Farther to the east, near Word's ranch, the series is much more calcareous in the upper and middle part; the thickness is more than 2,300 feet. Toward the west of the first-mentioned section, the shales begin to predominate, while the limestone is reduced in thickness. At the base of this formation is a conglomerate from 20 to 200 feet thick, and this unconformably overlies the Pennsylvanian." [Italics, Case. See also the description of the deposits in Trans-Pecos Texas on a previous page.]

To the north and west the stratigraphic equivalent, if not the continuation of the Hueco, is the Kaibab limestone of the Aubrey formation in the Grand Canyon section. A typical section from this region is given by Darton. ${ }^{3}$

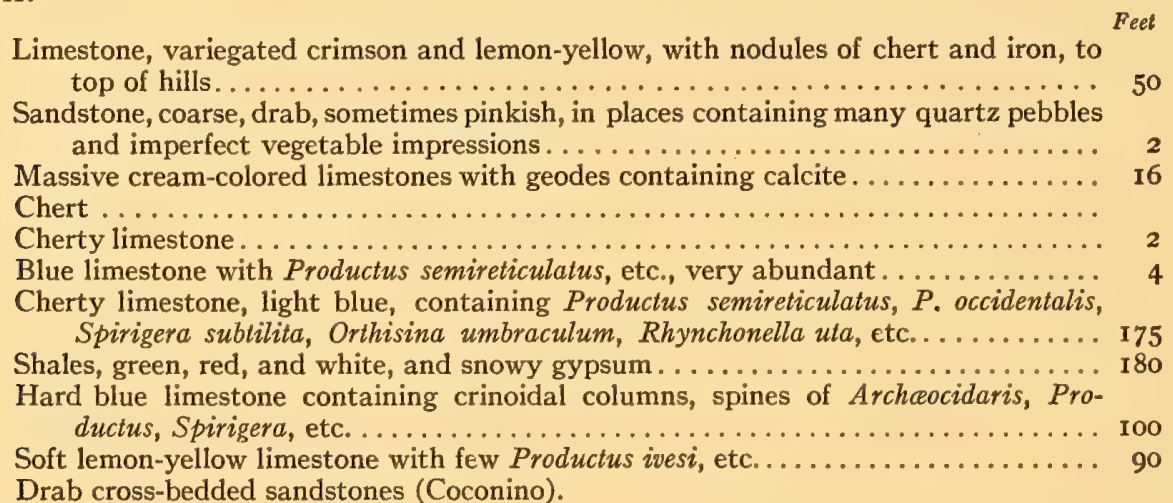

The connection between the two areas is shown by the occasional appearance in uplifts of rocks of similar appearance and probably equivalent age.

${ }^{1}$ Udden, J. A., Review of the Geology of Texas, Bull. 44, University of Texas, p. 47.

2 Idem, p. 5 I.

${ }^{3}$ Darton, N. H., A Reconnaissance of Parts of Northwestern New Mexico and Northern Arizona, Bull. 435, U. S. Geological Survey, p. 29, I9Io. 
According to Darton, such rocks occur in the Zuñi Uplift, at Ojo Caliente, and in the Nacimiento Mountains, all in northwestern New Mexico.

More directly north of the Guadalupe Mountains, but still west of the barrier between the two provinces, limestone of this horizon occurs in considerable quantity. Lindgren ${ }^{1}$ says that a considerable thickness of Pennsylvanian limestone existed over the whole State, with a maximum thickness between Santa Fe and Las Vegas. As far south as Socorro there is an alternation of shale and sandstone with the limestone, but south of this point limestone predominates, with a decrease in the total thickness. All the conditions indicate shore conditions in the northern part of the State, where some land existed even at this (Pennsylvanian) time. The land mentioned by Lindgren was, in part at least, the barrier between the Plains and Basin Provinces.

(b) Conditions in Nerw Mexico.-The upper Paleozoic rocks of New Mexico are divided into the Manzano formation and the Magdalena formation. The latter, and lower, is entirely Pennsylvanian, the former is in part PermoCarboniferous.

Near Socorro, the Magdalena formation is nearly I,500 feet thick, divided between the upper Madera blue limestone and shale and the lower Sandia limestone and shale, with minor quantities of sandstone. Lee ${ }^{2}$ gives a description of this limestone in its relation to the Manzano formation in central New Mexico. He says that in late Magdalena time an uplift, or other change, occurred in the mountain region of New Mexico which caused a change of sediment from limestone to red beds. In the Mimbres Mountains, near Kingston-

"The basal Magdalena strata consists of about 300 feet of dark-blue and gray limestone in thick beds with thin shale partings. The upper part of the group has about the same thickness and consists chiefly of blue and drab shales interstratified with several beds of limestone 15 to 20 feet thick. Unconformably overlying these beds are red sandstones and shales (Abo sandstone) of the Manzano group. $* * *$ There is no evidence on which to separate the group into Sandia formation and Madera limestone, as in the region farther west." 3

(c) Conditions in Arizona.-In southern Arizona the Pennsylvanian (?) limestone appears at Bisbee and Globe. Describing the first area, Ransome ${ }^{4}$ says:

"The Naco limestone $* * *$ is made up chiefly of light-colored beds, which consist essentially of calcium carbonate. The beds range in thickness from a

${ }^{1}$ Lindgren, W., L. C. Graton, and C. H. Gordon, Ore Deposits of New Mexico, U. S. Geological Survey, Professional Paper No. 68, pp. 3I-32, I910.

${ }^{2}$ Lee, W. T., and G. H. Girty, The Manzano group of the Rio Grande Valley, New Mexico, U. S. Geological Survey Bull. 389, 1909.

${ }^{3}$ Darton, W. H., A Comparison of the Paleozoic Sections in Southern New Mexico, U. S. Geological Survey, Professional Paper I08-C, p. 53, I9I7.

4 Ransome, F. L., The Geology and Ore Deposits of the Bisbee Quadrangle, Arizona, U. S. Geological Survey, Professional Paper No. 2I, p. 45, 1904. 
few inches to ro feet, but are usually thinner than those of the Escabrosa [Mississippian] limestone. [The Naco limestone is] compact and nearly aphanitic, ringing under the hammer, and breaking with a splintery fracture, whereas the Escabrosa limestone is usually more granular and crystalline, and crumbles more readily when struck. There are, however, exceptions to this rule, dense aphanitic beds occurring rarely in the Escabrosa formation and granular crinoidal beds being not uncommon in the Naco limestone.

"While the greater part of the 3,000 feet or more of the Naco formation is made up of fairly pure gray limestone, certain thin beds of a faint-pink tint occur at several horizons $* * *$. These pink beds, which weathering usually shows to have an inherent lamellar or shaly structure, are very fine grained and compact in texture. They effervesce freely with cold dilute acid and are evidently composed chiefly of calcium carbonate. Examination of natural surfaces with a lens, however, shows the presence of minute quartz grains and tiny flakes of mica. ***

"Chert is not uncommon in the Naco formation; it occurs sometimes as irregular bunches and nodules in beds of otherwise pure limestone and sometimes as the result of silicification of thin fossiliferous beds throughout their thickness. It is also particularly abundant along and near zones of fissuring and faulting.

"Conditions of deposition.-As littoral sediments are entirely lacking and terrigenous materials represented only by the very minute mica scales and quartz grains in the pink calcareous shale, it may fairly be concluded that the Naco limestone, which is not noticeably dolomitic, was deposited in moderately deep water at some distance from the shore, whence the tiny mica scales were derived. *** The region of deposition was in the main beyond the 'mud line,' which the results of the Challenger expedition showed to lie generally at a depth of 100 fathoms. During certain stages of the accumulations of the limestones, offshore currents carried some of the finest of the land waste into this area of tranquil deposition and left records of these occasional incursions in the form of pink shales."

Girty says, ${ }^{1}$ after listing the fauna of the Naco:

"Very few of these species have exact representatives in the Mississippi Valley Pennsylvanian ***. Productus iresi, Productus occidentalis, and Archeocidaris ornata are suggestive of the Aubrey limestone of the Grand Canyon section, just as the abundance of Omphalotrochus suggests the 'Permo-Carboniferous' of California. The whole fauna is closely related to that of the limestones of the Hueco Mountains in western Texas. *** Its age seems to be late in the Carboniferous, perhaps about the same as the series just referred to. The fauna has at the same time a very different facies from that of the Guadalupe fauna, as well as from that of the so-called 'Permo-Carboniferous' of the Mississippi Valley."

The top of the Naco is cut off by a great unconformity.

The Globe district was described by Ransome ${ }^{2}$ in 1903. Of the late Paleozoic deposits he says (page 40):

"Wherever thick sections of the Globe limestone are exposed it is found that the alternating buff and gray limestones with subordinate grits are overlain by

${ }^{1}$ In U. S. Geological Survey, Professional Paper No. 2I, page 54.

${ }^{2}$ Ransome, F. L., Geology of the Globe Copper District, U. S. Geological Survey, Professional Paper No. 12, pp. 40, I09, I903. 
gray, sometimes slightly pinkish, crinoidal limestones, usually in rather thick beds, but also some cherty beds and an occasional bed of siliceous conglomerate."

The lower part of this limestone is regarded as Mississippian and the upper part as Pennsylvanian. On page rog Ransome states:

"From the Devonian to the Upper Carboniferous the region was covered by a sea of some depth abounding in marine life and depositing abundant limestone. Although no characteristic Lower Carboniferous fauna was found, rocks of that period may be present, and the Globe limestone as a whole contains no visible unconformities. From time to time there were slight incursions of sediment, and in a few instances bands of siliceous conglomerate were intercalated within the limestones. The mass of these is unimportant, but they are significant in showing that this part of the Devonian and Carboniferous sea was probably neither very deep nor far distant from a land-mass.

"The Upper Carboniferous limestone is the latest Paleozoic deposit of which the region preserves any record. If marine conditions continued into the Permian the deposits of that period must have been wholly removed before the strata were broken up and invaded by diabase. Had Permian or later beds been involved in that structural revolution some traces of them would probably have been preserved in the resulting intricate lithological mosaic. $* * *$ The region was presumably elevated above sea-level at the close of the Carboniferous and subject to erosion."

[The Clifton-Morenci district in Arizona shows] "at least 500 feet of heavybedded bluish-gray limestone which unquestionably represents both the Mississippian and the Pennsylvanian. In a general way the lower 200 feet are equivalent to the Modoc formation, although its several members recognized farther south can not be identified, and the upper 300 feet represent the Pennsylvanian. It is not possible, however, to draw a dividing line, and the whole therefore has been included in the single formation named the Tule Spring limestone. $* * *{ }^{*} 1$

"Above the Morenci shales, ${ }^{2}$ in a deepening sea, were deposited a series of limestones, first dolomitic, then remarkably pure and rather coarse, the Modoc and Tule Spring limestones of the Mississippian and Pennsylvanian epochs. Throughout the whole of the Carboniferous animal life was abundant and rich faunas may be collected in many places."

The Pennsylvanian beds are cut off by the erosion face of a great unconformity.

In the Fort Apache, Arizona, region, according to Reagan, ${ }^{3}$ the uppermost beds belong to the Aubrey group:

"The interstream spaces of all the streams in their upper course as well as the south front of the Mogollon Range and the Cibicu Divide, where not covered with later deposits are capped with 280 feet of calcareous sandstone followed by 500 feet of soft red and gray shales, interrupted by sectile limestone. The Aubery (Kaibab) limestone occurs in one locality-at the head waters of the

\footnotetext{
${ }^{1}$ Lindgren, W., Description of the Clifton Quadrangle, Folio 129, U. S. Geological Survey, p. 5,1905 .

${ }^{2}$ Idem, p. I I.

${ }^{3}$ Reagan, A. B., Geology of the Fort Apache Region in Arizona, Amer. Geol., vol. xxxir, p. 280, I903.
} 
Cibicu and Canyon creeks. The rocks of this group are usually non-fossiliferous; but fossils enough were obtained (Athyris subtillita, Productus punctatus, Spirifer cameratus, Productus, and Bellerophon) to identify it as upper Carboniferous."

The upper Carboniferous of the Zuñi Plateau was divided by Dutton ${ }^{1}$ into the upper Aubrey and the lower Aubrey.

"The lower Aubrey consists of bright-red sandstones throughout, deposited usually in rather thick, and less frequently in moderately thin, layers. They are much alike in all outward respects, color, texture, and grouping, and in the erosional forms sculptured out of them. They are very fine grained, without traces of conglomerate or coarse shingle or gravels; and having a calcareous cement they weather easily and break down into very fine red sand. Fossils are scarce, but may be found here and there in sufficient quantity and distinctness to identify their age. These fossils, so far as I have seen, are the same as those which abound in the beds above them.

"The Aubrey is composed largely of sandstones, but they have a very different aspect from those below. In color they are yellowish-brown, and the cement, instead of being calcareous, is siliceous, in fact a regular chert. *** These sandstones are often conspicuously cross-bedded, and the silicification of the rock has in no way obscured it. *** There are several bands of these adamantine sandstones, and intercalated with them are three or four thick beds of pure limestone, containing an abundance of fossils of many and characteristic species."

(d) Conditions in Colorado.--In southwestern Colorado the uppermost Pennsylvanian deposits are the Hermosa and Rico.

The Hermosa is described by Cross and Howe ${ }^{2}$ as a series of alternating limestones, sandstones, and shales having a maximum thickness of 2,000 feet. In the Animas Valley the lowest third of the formation consists of green sandstones and shales with some gypsiferous shales; the rest of the formation has layers of limestone distributed throughout; toward the southwest the limestones become more important, with some beds reaching a considerable thickness.

In the Rico district the massive limestones are abundant only in the middle of the formation, the upper part being mainly black and gray shales alternating with green grits and sandstones, and a few limestones.

At Ouray the lower 300 feet are made up of thin alternating beds of sandstone, shale, and a gnarly, fossiliferous limestones.

The upper and greater part of the Hermosa consists of pink, massive grits and sandstones, red sandy shales, and gnarly fossiliferous limestones. The massive sandstones, which are coarse and gritty, vary from 50 to 75 feet in thickness and are separated from one another by the red shales and thin-bedded sandstones or calcareous layers. Heavy beds of limestone occur in the southwestern San Juan region, but are lacking near Ouray.

${ }^{1}$ Dutton, C. E., Mount Taylor and the Zuñi Plateau, U. S. Geological Survey, Sixth Annual Report, p. I32, I885.

${ }^{2}$ Cross, Whitman, and Ernest Howe, Ouray Folio, U. S. Geological Survey, No. I 53, p. 4, 1907 . 
The Cutler (Permo-Carboniferous) is apparently conformable on the Hermosa in the Ouray district.

In the same folio (Ouray, No. I53) Girty gives a list of the fauna occurring in the Hermosa and says (page 4 ):

"The fauna of the Hermosa formation occurs also in the Weber limestone and lower Maroon formation of the Crested Butte district, and in the Weber formation of the Tenmile and Leadville districts. From this fact and the similarity in stratigraphic occurrence a correlation of the formations seems to be justified. The Hermosa fauna represents early Pennsylvanian sedimentation, and it is probably older than the 'Upper Coal Measures' faunas of the Kansas and Nebraska section."

At Rico, Colorado, a distinct series of deposits overlies the Hermosa and is conformable with the overlying Cutler. This deposit seems to be somewhat local in character.

The Rico formation ${ }^{1}$ is about 300 feet thick and is made up of sandstones and conglomerates with intercalated shales and thin fossiliferous limestones which are usually sandy.

"The general characteristics of the Rico formation in the vicinity of Rico are, first, its calcareous nature, in which it resembles the strata above and below; second, the feldspathic constitution and the coarseness of its sandstones, in which respect it differs from the Hermosa and resembles the Cutler; and third, its chocolate or dark-maroon color, which contrasts sharply with the gray or green of the Hermosa and which is more or less distinct from the bright vermilion of the Cutler and Dolores. ***

"The bulk of the formation is made of sandstones and sandy shales composed of such materials as are derived from the disintegration of granite. The sandstones are mostly coarse or conglomeratic, always showing grains of fresh feldspar mixed with mica flakes and quartz. *** The coarser sandstones are usually cross-bedded and occur in massive beds from 2 or 3 to 25 feet in thickness. Some of the coarser sandstones are of very much lighter color than the mass of the formation. When fine-grained the sandstones are usually somewhat laminated and pass into sandy shales. The shales, aside from the sandy varieties, are of two kinds - the fine-grained, unlaminated, red, marly beds, similar to those of the Cutler, and the equally fine-grained, laminated clay shales of a green color.

"Intercalated with the sandstones and shales, which are for the most part very calcareous throughout, there are several beds of impure limestone, some as earthy, gray, sometimes nodular bands associated with the marly shales, and others as sandy limestone of a red color, in strata from 6 inches to 2 feet in thickness."

Fossiliferous sandy limestone layers occur as lenses shading into the sandstone both horizontally and vertically. One or two are very persistent. The Rico pass conformably into Cutler with no sharp distinction.

Cross and $\mathrm{Howe}^{2}$ give the following statement with regard to the relation of the Hermosa and Aubrey:

${ }^{1}$ Cross, Whitman, and F. L. Ransome, Rico Folio, No. I30, U. S. Geol. Sur., p. 3, I905.

${ }^{2}$ Cross, Whitman, and Ernest Howe, Red Beds of Southwestern Colorado and Their Correlation, Bull. Geol. Soc. Amer., vol. 16, p. 466, 1905. 
"The Hermosa and Aubrey [Kaibab] faunas are both regarded as Pennsylvanian, but Mr. Girty informs us that the Hermosa has no species in common with the typical Aubrey [Kaibab] of the Grand Canyon section, as far as known. Mr. Girty further states that the lower Aubrey fauna from beds at the junction of the Grand and Green Rivers, comprising a large part of the Aubrey fauna described by White in Powell's Unita report, is markedly different from the Aubrey of the Grand Canyon, as it also is from the Hermosa fauna of Colorado. These faunal differences must seemingly be explained in one of three ways: (I) by a rapid gradation of forms within a comparatively narrow zone; (2) by the assumption of an effective barrier between the Aubrey and Hermosa seas, extending for hundreds of miles from eastern New Mexico west and northwest across New Mexico and Utah; or (3) by assuming one of the formations to be younger than the other, and that the Pennsylvanian section is incomplete both in Colorado and in the Plateau country ***."

It is probable that the Hermosa is the equivalent of the Weber interval to the north and either equivalent to, or a continuation of, the Aubrey. If the latter, there is evidence of a transition into the conditions which determined the Weber grits which cover such a large area to the north.

The first appearance of the Weber formation in a locality where it has been described is in the area of the Tenmile quadrangle in west central Colorado. In this region, Emmons ${ }^{1}$ says of it:

"Weber formation.-This formation constitutes the most siliceous member of the Carboniferous system, and corresponds in a general way to the Weber quartzite of the Wasatch Mountain section and to the Lower Aubrey [Kaibab] of the Colorado Canyon section. It includes a lower calcareo-argillaceous member, designated in the Leadville report the Weber shales, the main siliceous formation being there called the Weber grits.

"The Weber shales constitute a transition series between the massive limestones below and the coarse sandstones of the Weber grits above. They consist in the Mosquito Range of argillaceous and calcareous shales, alternating with quartzitic sandstones. The former are generally very carbonaceous and often contain seams of impure anthracite, up to several feet in thickness, but of no commercial value. The calcareous members sometimes develop considerable beds of impure limestones, generally fossiliferous, which are distinguished from those of the lower formation by fossils that are exclusively of Coal Measure aspect. The thickness of this series, which is very variable, is assumed in this region to be about 300 feet. It occurs in the valley of Eagle River, just west of the limits of the quadrangle.

"To the Weber grits belong the lowest beds exposed in the Tenmile district west of the Mosquito fault. Their average thickness here, as in the Mosquito Range, is about 2,500 feet. They consist mainly of coarse sandstones or grits, often very micaceous, with a subordinate development of shales and a few thin and non-persistent beds of dolomitic limestone. The sandstones are generally light gray in color, but near the base of the series are sometimes quite dark from the presence of finely divided carbon, probably in the form of anthracite or graphite. Their prominent constituents are quartz and feldspar, evidently derived from the Archean; pink orthoclase is sometimes so abundant as to

${ }^{1}$ Emmons, S. F., Tenmile District Special Folio, No. 48, U. S. Geological Survey, p. I, I 898. 
impart a reddish tinge to the rocks. The abundant mica is mostly muscovite, biotite being present in subordinate quantity. The muscovite is probably of secondary origin, for it is present in much greater quantity than could reasonably be expected, if it were directly derived from the Archean, and in larger leaves than is common among the gneisses observed.

"In the Mosquito Range two beds of limestone, each about 5o feet in thickness, are found about the middle of the formation. In this district the limestones are more prominent in the upper part, but are very irregularly developed. Six different beds were observed on the south face of Sheep Mountain, but at other points not over two could be detected. They are generally rather thin, but the principal bed in the northwestern part of the district is 60 or 80 feet thick. At the southern boundary of the area this bed can not be detected, and has apparently thinned out. The great variability of the many thin beds of limestone in this and the succeeding formation is so remarkable that these have been designated on the map by a special color, which shows approximately the variable extent of calcareous sedimentation in the midst of a great thickness of prevailingly coarse siliceous deposits. The limestone beds are also important in defining horizons, and to them are confined a large and important class of the ore deposits of the district.

"The limestones in the Weber grits are all typical dolomites, with a small but persistent admixture of carbonates of iron and manganese ( $I .5$ to 5 per cent) and up to Io per cent of insoluble matter.

"Maroon formation.-This name is here applied to about I,500 feet of beds which in many respects resemble the Weber grits, but which in the Mosquito Range have a much larger proportion of calcareous and argillaceous beds. This formation in the Tenmile district consists predominantly of coarse gray and red sandstones, in some places passing into conglomerates, with many irregularly developed beds of limestone. As contrasted with corresponding members of the Weber grits, the following distinctions have been noted. The red color of the sandstones, which is more common than in the lower formation, though less pronounced than in the beds of the next above, results not from the presence of pink feldspar, as in the Weber grits, but from abundant iron oxide impregnating the cement. Hence in depth, as shown in underground workings, the red color generally gives way to a greenish gray. The strata in which the red color is most pronounced are fine-grained and often somewhat schistose. These sandstones also contain a large proportion of feldspar fragments. In one case it was found that a mixture of carbonates had almost wholly replaced the abundant feldspars, which, nevertheless, were to all outward appearances quite fresh.

"The argillaceous shales are often black, but seldom contain actual coal; they are much more abundant than would appear from a hasty inspection of the hill slopes, where their outcrops are readily obscured by the débris from the harder rocks.

"The limestones of the Maroon formation constitute, however, its most characteristic feature, and, independently of color, seem to afford the safest means of distinguishing it from the Weber grits. In outward appearance they are purer and are evidently freer from arenaceous material. They are light bluish gray or drab in color, becoming white on weathered surfaces, in strong contrast with the dirty brown weathered surface of the dolomites. They have also a conchoidal fracture and lithoidal structure, instead of the rough granular fractured surfaces which characterize the latter. Chemical analysis confirms these indica- 
tions, an examination of nine specimens proving that, with one exception, they are non-magnesian limestones with a variable but generally small percentage of insoluble material, and less than I per cent of $(\mathrm{FeMg}) \mathrm{CO}_{3}$. In the limestone from Tucker Mountain, which forms the exception, the dirty brown weathered surface and granular texture already noted suggest the dolomitic character and the presence of iron and manganese carbonates. Furthermore, in the absence of definite faunal distinctions the limestone beds have been used to define the limits of the formation, the base being taken at the limestone belt known as the Robinson limestone, and the top of the formation at the Jacque Mountain limestone. Both these limestones contain an invertebrate fauna of upper Coal Measure type. The Robinson limestone is somewhat dolomitic at the base, containing nearly 7 per cent of magnesium carbonate. The Jacque Mountain limestone is characterized in certain layers by an oolitic structure. The rock is light bluish gray in color, and the oolitic grains are embedded in a finely granular matrix of similar color. They are about the size of mustard shot, and have a normal concentric structure and sometimes a radiate appearance; grains of sand or crystal particles serve as nuclei. This structure disappears with recrystallization, and is entirely wanting in certain layers.

"Wyoming formation.- The beds above the Jacque Mountain limestone, which have a maximum thickness of about 1,500 feet, have been given this name, not because of any fossil evidence of their age that could be found, but because by their position and petrological character they most nearly correspond to the beds of this formation which elsewhere in the Rocky Mountain region have, on fossil evidence, been determined to be Triassic. If the Permian is represented in Colorado, the evidence of which appears to the writer as yet very uncertain, it would be included in these beds, which have evidently been deposited in direct and unbroken succession over the upper Carboniferous.

"They consist principally of sandstones, of intensely brick-red color where not metamorphosed, with a moderate development of thin shales between their more massive beds. Limestones are practically absent, having been found only at a few isolated points, generally at about the same horizon, showing that the conditions favoring calcareous sedimentation, which had hitherto prevailed so irregularly throughout the region, had at this time almost entirely ceased. The sandstones are often coarse, sometimes conglomeratic, and are composed mainly of distinctly recognizable Archean débris. Feldspar and mica are the most abundant constituents next to quartz. Near the top of Jacque Mountain there is a conglomerate bed containing Archean bowlders as large as 2 feet in diameter; finer conglomerates are abundant, in beds usually not over $\mathrm{I}$ or 2 feet in thickness. In one place, on the Tenmile slope of Mayflower Hill, a conglomerate bed was observed where the pebbles were entirely of white quartzite in a matrix of nearly pure quartz sand. On the slope of the hills bordering Tenmile Valley on the west, especially of Jacque, Tucker, and Copper mountains, where metamorphic action has been most pronounced, the red color has disappeared from the Wyoming sandstones, and the rock has become dark and quartzitic and contains much bright-green epidote."

Similar conditions occur in the Anthracite-Crested Butte and the Aspen quadrangles.

It is obvious that the red sandstone here mentioned above the Weber grits is not to be directly correlated with the Wyoming formation or its 
equivalent, for these belong entirely upon the eastern side of the Rocky Mountain barrier within the Plains Province. Aside from the remote possibility of an arm or extension of the depositional area from the Plains Province to the west across the barrier in this locality, the probability is that these red beds are an extension of the Rio Arriba Beds (New Mexico) and Cutler Beds (southwestern Colorado) to the north.

Beyond the limits of southwestern and western Colorado, to the west and northwest, the red beds cease to appear in their characteristic development, but the deposit of the equivalent period seems rather to be changed in character than to be absent from the geological column. To realize the geographical continuation of the upper Pennsylvanian surface which marks the beginning of the Permo-Carboniferous series it is most convenient to trace the position of the Weber quartzite, already fixed in its relations to the Hueco limestone of the Guadalupe Mountains. The Weber quartzite or sandstone, which is one of the most widely distributed and easily distinguished horizons of the Pennsylvanian, is said by Hague to stretch all the way from the Front Range in Colorado to the Eureka Mountains and can be traced north, to southern Wyoming.

(e) Conditions in Nevada.- In the Eureka area, according to Hague, the Weber is overlain by 500 feet of upper Pennsylvanian limestone, but its thickness has been reduced by erosion. In the northern and central portions of the State the beds are 2,000 feet thick. They are distinguished by their light color and the prevalence of fine-grained beds. "These colors are light bluish-gray and drab, the latter possessing a conchoidal fracture and compact texture. *** Throughout the horizon the limestones are interstratified with belts of grit and siliceous pebbles, held together by a calcareous cement, in which are intercalated thin beds of purer limestone." These limestones are very free from $\mathrm{MgCO}_{3}$, the only Paleozoic horizon at Eureka free from dolomitic strata.

A similar condition seems to be traceable to the northwest, where at Battle Mountain, Nevada, $\mathrm{Hill}^{1}$ reports the following conditions:

"Limestones. - The limestones are well exposed on Antler Peak, and a small area underlain by these rocks occurs west of the rhyolite cap rock at the east side of the mountains west-southwest of Battle Mountain. Of the limestones of Antler Peak the Fortieth Parallel geologists say: 'They extend from the summit to the very bottom of Willow Canyon ***, exposing I,200 feet of heavily bedded, dark-gray limestones in places somewhat shaly and of light bluish-gray tints.

"Carboniferous fossils were found near the base and roo feet below the summit of these beds.

"The writer collected some fossils from the limestones exposed on the eastwest ridge at a point 7 miles west of Battle Mountain, under the rhyolite cap.

${ }^{1}$ Hill, James M., Some Mining Districts in Northeastern California and Northwestern Nevada, U. S. Geological Survey Bull. 594, p. 66, 1915. 
The three lots collected were examined by G. H. Girty, of the Survey, who reports the following species: Amboccelia planiconvexa, crinoid stems, Productus? sp., Chonetes aff. C. geinitzianus, which he says are 'probably Pennsylvanian, though the faunas are too limited to be really diagnostic.'

"Red sandstones.-The red and brown sandstones and conglomerates form a broad northward-lying belt along the central part of the eastern slope of the mountains, being the prevailing rocks in the vicinity of Galena and showing in great force in Copper Canyon and the ridge east of that canyon. As a rule the eastward lower beds of this series are arenaceous shales and sandstones of light red and yellow color. The lower central part of the series is conglomeratic. The well-rounded pebbles are largely white quartzite and a dense red jasperoidal material. They range from one-eighth to one-half inch in diameter, though a few larger cobblestones occur. The matrix is a yellowish, red-weathering sand of rather coarse texture. Interbedded with the conglomerates there are numerous irregular, lenslike masses of red sandstone. In the upper part of this series the material becomes fine grained, passing into dirty brown sandstones that contain considerable mica.

"White quartzite.-The ridge between Copper Canyon and Willow Creek, at the southwest side of the mountains, is composed of a white vitreous finegrained quartzite, somewhat similar to the hill north of Cottonwood Canyon in which the Little Giant vein occurs. At the former locality the beds dip west at very steep angles and apparently have been faulted into their present position. $* * *$

"The two formations discussed above (the red sandstone and the white quartzite) are presumably to be correlated with the Weber quartzite of the Fortieth Parallel Survey reports."

( $f$ ) Conditions in Utah.-From the region east and northeast, the same horizon can be traced through the Canyon Range and Oquirrh Range south of the Great Salt Lake as the Bingham quartzite to the Uintah and Wasatch Mountains. Loughlin ${ }^{1}$ says:

"The quartzite as a rule is of fine, even grain and varies in color from nearly white to light and dark brown or reddish brown. Some of its beds are greenish. Its general appearance is very similar to that of the thick Cambrian quartzite exposed in the Tintic district and at several places along the Wasatch Range. $* * *$

"The quartzite contains a conspicuous and persistent dark-reddish finely banded member, 400 or 500 feet thick, which is a convenient horizon marker and indicator of the geologic structure. $* * *$ One lens of gray limestone $* * *$ was noted on the north side of Fool Creek canyon. Detailed study may prove the presence of several such lenses. ***

"No fossils were found in the quartzite, but its apparent conformable position above limestone of Madison age suggests that its lower part at least is Mississippian. Its upper part may be Pennsylvanian. A similar quartzite of great thickness, containing some limestone beds, forms the greater part of the West Tintic Mountains, the southern end of which is almost connected with the northwest end of the Canyon Range, and the writer has found upper Mississippian

${ }^{1}$ Loughlin, G. F., A Reconnaissance in the Canyon Range, West Central Utah, U. S. Geological Survey, Professional Paper No. 90, p. 54, I9I4. 
fossils in the limestone beds. Correlation, therefore, with this quartzite fixes the age of the quartzite of the Canyon Range as upper Mississippian.

"The upper Mississippian studied by the writer in the Tintic Mountains north of the Canyon Range and east of the West Tintic Range consists of a thick series of alternating limestone, shale, and sandstone or quartzite beds. The same series, 5,000 to 6,000 feet thick, is present in the southern part of the Oquirrh Range, and is overlain by the thick Bingham quartzite, which has been referred by Girty to the Pennsylvanian series. In the Wasatch Mountains the same intercalated series of limestones, shale, and sandstone is overlain by the Weber quartzite of Pennsylvanian age. These data indicate a transition northward and eastward from quartzite into strata composed largely of limestone and shale, and suggest that in late Mississippian and Pennsylvanian time the deposition of siliceous sediment was extended northward and eastward, overlapping the intercalated beds of limestone, shale, and sandstone."

Granting the equivalence of the quartzite beds in the Canyon Range, the Bingham quartzite of the Oquirrh Range, and the Weber quartzite of the Uintah and Wasatch Mountains brings this formation close to the western and northwestern edge of the Red Beds in Colorado.

In the Uintah Mountains the Weber formation includes the Weber quartzite at the base. It is described by Weeks ${ }^{1}$ as follows:

"Weber formation.-The lower part of this formation is a white and gray to greenish quartzite in thin and thick beds, some of which weather brown. In the upper part of the formation are alternating blue and white siliceous limestones and quartzites. The transition to the next series is through blue and reddish limestones and shales. The greatest thickness occurs on the south side of the Weber River, on the north slope of the range.*** This formation, like the 'Uinta,' is quartzitic in the western and central parts of the range and grades into a rather soft sandstone in the eastern part. No fossils were found in the Weber formation.

"Permian, Permo-Carboniferous-Nomenclature and correlation.-The PermoCarboniferous series of the Uinta Range seems to correspond in position, thickness, and general lithologic characters to the Upper Coal Measure and PermoCarboniferous formations of the Fortieth Parallel Survey. On similar grounds they may be correlated with the Aubrey limestone of Walcott's Grand Canyon section. The correlation with Powell's section is less definite. The limestones overlying the Yampa sandstone of the Upper Aubrey group and an undetermined thickness of the shales and soft sandstones of the Shinarump group appear to correspond to the beds under discussion.

"Description.-The upper beds of the Weber formation are calcareous sandstones and siliceous limestones which weather yellow and grade into the thin red shales and red and blue limestones of the upper part of the Permo-Carboniferous series. ***

"One of the best sections occurs on the east side of Duchesne River below the mouth of West Fork. There the lower 600 feet of the Permo-Carboniferous are formed of the red and purple shales and blue limestones. Above is I,000 feet of light gray and white sandstones, with some interbedded limestones in the

${ }^{1}$ Weeks, F. B., Stratigraphy and Structure of the Uinta Range, Bull. Geol. Soc. Amer., vol. 18, p. 438,1907 . 
lower part. In the upper part these sandstones occur in alternating layers of soft and compact beds full of peculiar black points or specks. These are succeeded by 800 to 900 feet of red shales, with a prominent band of light-colored shale at the top."

In northwestern Utah the Weber quartzite continues as a strong horizon, but gradually plays out to the northeast of Ogden, Utah. The occurrence of the quartzite is described by Blackwelder:1

"At the type locality in Weber Canyon the quartzite is said to be 5000 to, 6,000 feet thick, but it thins toward the north and entirely disappears within 8 miles, so that farther north the Park City formation is everywhere directly in contact with the Mississippian strata. At the base of the Weber quartzite and intergrading with it, there are red beds consisting of brick-red sandstone with some sandy shale and thin beds of cherty gray limestone. The limestones have yielded a few fossils that are closely related to those in the lower part of the Weber quartzite, and are considered by Girty to be of Pennsylvanian age. The red beds are separated from the underlying limestones by a distinct unconformity, but the testimony of the fossils seems to indicate that the interruption of deposition was brief. The Weber quartzite proper consists of creamy-white quartzite or hard sandstone interbedded, particularly in the lower part, with cherty dolomites of dark gray to black color. A characteristic of the upper beds of the quartzite is a coarse pitting of the surface which is probably due to the leaching out of calcite unevenly distributed through the formation."

In the Park City district of Utah, adjacent to the area discussed by Blackwelder, the Weber quartzite continues and was described by Boutwell ${ }^{2}$ in I9I2:

"The Weber quartzite, as it outcrops in this region, consists of gray quartzite with comparatively insignificant occurrences of cherty patches and intercalated limestone. It is characterized by massiveness both in bedding, the beds being rarely less than 4 and in many places 8 to 15 feet in thickness, and in the absence of parting planes. On fresh fracture it is a light brownish gray, and it weathers to a glistening surface of a lighter shade. The normal quartzite is fine and even grained and dense. The exceedingly brittle nature of the rock causes it to break into sharp, irregular fragments, and when ground fine in a fracture zone it appears as a glistening white sugary filling inclosing larger fragments. $* * *$ It has been metamorphosed into quartz so completely that the granular form of the original sand is rarely discernible. $* * *$

"The middle and basal portions of this formation, which are not present in this area, outcrop in prominent cliffs just south of the district. Except for a few thin limestone beds near its top, the middle portion is massive quartzite, but in the lower part the intercalated limestone members increase in number and thickness. In Big Cottonwood Canyon a few limestones are intercalated. A thin crinoidal sandstone occurs about $\mathrm{I} 30$ feet from the top, a thin pitted, cavernous, grayish-white quartzite 460 feet below that, and a thinly banded calcareous

${ }^{1}$ Blackwelder, Eliot, Phosphate Deposits East of Ogden, Utah, U. S. Geological Survey, Bull. 430, p. 540, 1909.

2 Boutwell, J. M., Geology and Ore Deposits of the Park City District, Utah, U. S. Geological Survey, Professional Paper No. 77, p. 45, 1912. 
quartzite 430 feet farther down. In Weber Canyon this great formation is most characteristically exposed as a massive, dense, homogeneous quartzite. The insignificant exceptions are a curiously pitted and marked stratum of quartzite just below the top and a few thin limestones in the basal portions. $* * *$

"The passage from this great quartzite into the overlying formation has been a subject of considerable study without definite results. One geologist reported that a marked uniformity [unconformity?] existed between this quartzite and the overlying limestone. During the present survey, however, excellent exposures showed apparently complete conformity. The lithological character of the sediments also indicated that a full record is here found of a normal gradual transition. Exposures in Woodside Canyon show a succession of calcareous sandstones, normal sandstones, and arenaceous quartzites immediately above characteristic massive Weber quartzite-apparently a normal transition. In Big Cottonwood Canyon, a few miles west of this area, the quartzite gives way upward to a sequence of sandy beds. In Weber Canyon the precise contact was not sufficiently exposed to demonstrate conformability, but the evidence obtainable pointed to that condition."

Schultz, ${ }^{1}$ in I9I8, gave the following account of the Weber quartzite in the Uinta Mountains:

\section{"Weber Quartzite (Pennsylvanian).}

"Overlying the massive Pennsylvanian limestones, which may be considered as at least in part equivalent to the Morgan formation of the Wasatch Range, is a thick massive gray to white quartzite or sandstone that has been correlated with the Weber quartzite of the Wasatch Range. With this quartzite are associated small quantities of chert and limestone. The absence of impurities and cementing material is conspicuous. On fresh fracture the quartzite is pure white to light brownish gray and it usually weathers to a light shade, although in some localities it has a decided brownish color. The quartzite or sandstone is fine, even grained, and dense. The exceedingly brittle nature of the rock causes it to break into sharp, irregular fragments that form conspicuous talus slopes. In some localities the sandstone has been so completely metamorphosed into quartzite that the form of the original constituent grains is not readily discernible by the naked eye. In many other places along both sides of the range, however, the Weber quartzite is nothing more than a rather soft sandstone in which the original grains are poorly cemented and readily detected and which on weathering produces a fine-grained sand remarkably free from impurities. Good exposures of this formation may be seen along both sides of the Uinta Range west of Green River wherever the beds have not been obscured by the overlying Tertiary deposits or by the Bishop conglomerate, of late Tertiary or early Quaternary age. The distribution of these beds is shown on the accompanying map [Pl. V, in the original publication]. East of the area examined and east of Green River the Weber quartzite beds are exposed by erosion at many places along the south flank of the mountains and along the crest of the Midland anticline at the south side of Blue Mountain, in Colorado, where it forms the center of the oval basin south of Midland Ridge.

\footnotetext{
${ }^{1}$ Schultz, A. R., A Geologic Reconnaissance of the Uintah Mountains, Northern Utah, with 10 Especial Reference to Phosphate, U. S. Geological Survey, Bulletin 690-C, p. 45, I918.
} 
"The total thickness of this formation is approximately 2,200 feet in the western part of the Uinta Range and about I,600 feet in the vicinity of Green River. Powell gives the thickness in the east end of the range as $\mathrm{I}, 000$ feet or more."

Schultz here discusses the possibility of an unconformity at the base of the Weber and decides that no such unconformity exists.

(g) Conditions in Idaho.-The Weber quartzite extends into southwestern Idaho, where it undergoes a considerable change, indicating an approach to its northwestern limit. Richards and Mansfield ${ }^{1}$ describe it as follows:

"The Weber quartzite in the area examined in I909 consists chiefly of massive white quartzite with subordinate amounts of shale and calcareous sandstone or limestone. In the region studied during the present year the conditions are practically reversed, and the true quartzite is subordinate to calcareous sandstone and limestones. The character and position of the small amount of quartzite present are extremely variable. ***"

(h) Conditions in Wyoming.--In southwestern Wyoming the Weber consists of gray and white quartzitic sandstone, often brecciated, reaching a thickness of $500 \pm$ feet. Veatch says of this area: ${ }^{2}$

"From this time [Pennsylvanian] until late Cretaceous there was no profound disturbance. The strata, so far as can be seen, are entirely conformable and the series is complete, but the absence of beds found in other portions of the Rocky Mountains suggests that there were land periods during this interval, produced by broad orographic movements without pronounced deformation in this area.

Blackwelder has given a more detailed discussion of the Weber and adjacent formations in Wyoming. ${ }^{3}$

"Above this limestone [the Madison, Mississippian] is a sandy series, which is somewhat variable in different parts of the region. The larger part of it comprises the Weber quartzite in southeastern Idaho and Utah and the Tensleep sandstone in central Wyoming. Its basal portion generally contains beds of red shale and purple or gray limestone, and where thus developed in Utah has been called the Morgan formation, while in eastern and north-central Wyoming Darton has named the corresponding beds the Amsden formation. The upper and larger part of the sandy series is generally a massive yellowish or creamcolored sandstone (Tensleep) in the east, or a quartzite (Weber) in the southwest. On account of resistance to erosion the outcrops of the Weber, Tensleep, and equivalent rocks are almost invariably marked by ridges or peaks, and in canyons by cliffs. $* * *$

"Between these two conspicuous horizon markers, the yellow sandstone below and the red shales above, lie the less-resistant strata which include the phosphate beds. In north-central Wyoming, where these strata are relatively thin, Darton

${ }^{1}$ Richards, R. W., and G. R. Mansfield, Preliminary Report on a Portion of the Idaho Phosphate Reserve, U. S. Geological Survey, Bull. 470, p. 385, I9I0.

${ }^{2}$ Veatch, A. C., Geography and Geology of a Portion of Southwestern Wyoming, U. S. Geological Survey, Professional Paper No. 56, p. 49, 1907.

${ }^{3}$ Blackwelder, Eliot, A Reconnaissance of the Phosphate Deposits of Western Wyoming, U. S. Geological Survey, Bull. 470, p. 458, I910. 
has named them the Embar formation. These beds increase in thickness and change considerably in character in passing westward to the Hoback and Salt River ranges, and there they may be divided into several formations, corresponding probably to those recognized by Gale in southeastern Idaho and Utah, namely, the phosphatic Park City formation below, the Woodside shale in the middle, and the Thaynes limestone at the top. As not all parts of these strata are fossiliferous, the exact equivalence of the divisions in the eastern and western sections has not been established, but it seems to be approximately as stated. The phosphate beds lie near the base of the Embar formation to the east and the Park City formation to the west and are associated with dark shale and fossiliferous limestone. In the Gros Ventre Range the limestone above the phosphate beds is largely replaced by chert and fossils are very scarce.

"The individual beds of phosphate rock are subject to much variation in character and richness. In the western sections they are generally considerably thicker than in the east and northeast. The richest variety of phosphate rock is commonly a black oolithic material-firm but not particularly hard. When broken it emits a disagreeable odor of petroleum. From this richer variety there are all gradations, through hard phosphatic limestone and soft phosphatic shale and sandstone down to beds that contain but little phosphoric acid.

"In the canyon of Snake River in western Wyoming the total thickness of phosphatic beds, both rich and lean, exceeds 40 feet. ***

"On the north side of the Wind River Range the phosphate beds have dwindled to 3 or 4 feet in thickness and consist largely of gray phosphatic sandstone, which contains only 35 to 45 per cent of tricalcium phosphate. Across the Wind River Valley, in the Shoshone and Owl Creek mountains, the deterioration of the phosphate deposits is still more marked, for there the beds are but 2 to 4 feet thick and generally contain less than 20 per cent of tricalcium phosphate. ***

"From the work of other geologists in Wyoming it is believed that phosphate deposits exceeding a few inches in thickness do not occur much north of the Owl Creek Mountains, northeast of the southern part of the Bighorn Range, nor east of the low ranges between Casper and Lander. There is no information as to the southward extension of the material, but it has never been recognized south of the Wind River Range in Wyoming. It is highly probable, however, that lean phosphate beds of some importance stretch north by west across Yellowstone Park into southern Montana. ***"

From the Gros Ventre Mountains northward and eastward it is scarcely practicable to discriminate the formations known as Park City, Thaynes, and Woodside in southeastern Idaho and northern Utah. The corresponding interval is occupied by a gray or buff alternation of shale, limestone, and chert, with black layers of shale and phosphate rock, which is believed to represent the Embar formation.

To the west of the areas described by Dale, Richards, and Mansfield there is evidence of the continuation of the Weber quartzite horizon. Lindgren $^{1}$ in 1899 described the Wood River series. The rocks are all badly disturbed and in places metamorphosed by contact with the great

${ }^{1}$ Lindgren, W., The Gold and Silver Veins of Silver City, De Lamar, and Other Mining Districts in Idaho, 2oth Annual Report, U. S. Geological Survey, "part III, pp. 89-90 and $194,1899$. 
central granite mass of Idaho. On page 194 Lindgren speaks of these rocks as follows:

"The rocks of the series consist of a comparatively small amount of heavybedded gray limestones and a large mass of quartzitic sandstones of red, gray, or brown color. Very frequently these are more or less calcareous. Black shales, usually calcareous and frequently banded, gray and black, are also abundant, and contain most of the veins in the district. Occasionally slaty rocks are met with, showing the effects of great compression in slaty cleavage, frequently in two directions."

A number of casts of fossils were found in a hard, grayish brown, partly calcareous quartzite which have been identified by Schuchert as Myalina (two species), Schizodus, Allorisma, Scaphiocrinus or Graphiocrinus, and Fusulina (?). Dr. Schuchert ${ }^{1}$ says concerning this fauna:

"The identification of Fusulina is doubtful, since only two large cross-sections are shown embedded in the rock. They are pseudomorphs in calcite, and preserve only the spiral layers of growth. If Fusulina is present the horizon is upper Carboniferous. The presence of Scaphiocrinus or Graphiocrinus often indicates a rather lower horizon-lower Carboniferous-though Graphiocrinus is also found in the upper Carboniferous. The pelecypods indicate no special horizon in the Carboniferous. For the present I am inclined to view these fossils as probably upper Carboniferous."

In northwestern Wyoming and southwestern and western Montana, the horizon of the Weber quartzite becomes somewhat mixed, limestone, sandstone, and shale layers occurring at frequent levels and sometimes dominating the quartzite. The deposits in this region are called Quadrant quartzite, and there has been considerable difference of opinion as to its exact age and correlation with other beds, but there can be little doubt that the Quadrant quartzite, or a part of it, is the equivalent of the Weber quartzite and that its deposition was due to similar conditions.

In the Yellowstone National Park, ${ }^{2}$ the Quadrant quartzite-

"consists of white, yellowish and occasionally pink beds of quartzite, with intercalated beds of drab saccharoidal limestones. The quartzite is generally" compact, occurs in beds from 4 to 25 feet in thickness, and weathers in massive blocks. More rarely it breaks into small fragments that form débris slopes, as seen in the Teton Range. The total thickness averages 400 feet in the Gallatin Range. In the southwest corner of the park it is far less prominent than in the Gallatin, but its resistance to weathering makes it easily recognizable, outcropping beneath the soft red clays of the Juratrias.

(i) Conditions in Montana.-At Three Forks, Montana, the quartzite of this horizon is less dominant, except at the top. In the description of this area by $\mathrm{Peale}^{3}$ the following account is given:

${ }^{1}$ Schuchert, in Lindgren, 20th Ann. Rept. U. S. Geol. Sur., p. 90.

2 Yellowstone National Park Folio, No. 30, U. S. Geological Survey, p. 5, I896.

${ }^{3}$ Peale, A. C., Three Forks, Montana, Folio No. 24, U. S. Geological Survey, p. 2, 1896. 
"After the deposition of the Madison limestones there seems to have been a marked change in the character of the sediments, due possibly to the prevalence of much shallower seas or to more active erosion of land areas. The lower beds, to which the name of 'red' limestone has been given, are everywhere arenaceous and argillaceous, and in many localities a conglomerate of limestone pebbles lies at the very base of the formation. Although no true dolomites are found, these lower limestones are all more or less magnesian. The section varies considerably at different points, but its thickness is between 300 and 400 feet. The red limestone is from I 70 to 200 feet thick, and the brilliant red color of its débris makes it very conspicuous, while its soft character leads to the development of a ravine back of the outcrops of the Madison limestone. The fossils found in the red limestone are of upper Carboniferous age. Following the red limestone are from I 50 to I80 feet of thin-bedded, cherty limestone, alternating with quartzitic layers, the latter predominating at the top and being capped by a prominent bed of quartzite or quartizitic sandstone, which has been taken as the base of the overlying Mesozoic."

At Old Baldy, near Virginia City, the limestone is capped by the Quadrant quartzite. Immediately below the quartzite there is a considerable thickness of limestone which contains Pennsylvanian fossils. Schuchert considered these as Pottsvillian (Bull. Geol. Soc. Amer., vol. 20, p. 559, I9I0). The Quadrant sandstone is certainly calcareous at its base, and also fossiliferous.

In the description by $\mathrm{Clark}^{1}$ of the rocks of southwestern Montana the position of the Quadrant is given as well up in the Pennsylvanian in opposition to the opinion expressed by Girty, ${ }^{2}$ who regards it as Mississippian, in some places at least.

Near Melrose, Montana, which lies about 27 miles directly south of Butte, the Quadrant lies in almost the same position and relations as the Weber occupies in southeastern Idaho and the adjacent portions of Utah and Wyoming. Gale says: ${ }^{3}$

"The quartzite of the Quadrant is overlain by light, sandy-weathering blue limestone, about I30 feet thick in the Melrose section. This limestone contains much black chert in nodular form and in layers. The phosphate bed immediately overlies this sandy blue limestone and is itself overlain by ledges containing much massive chert, so that the stratigraphic section here corresponds remarkably in lithologic character with the sequence of strata typically associated with the phosphate beds in southeastern Idaho."

Near Dell and Dillon, Montana, Bowen ${ }^{4}$ reports the following sequence:

"Overlying the limestone (No. 2) (of Mississippian age) is a great thickness of sandstone containing some highly calcareous beds and possibly some true lime-

${ }^{1}$ Clark, T. H., Bull. Mus. Comp. Zool. Harvard University, vol. LxI, No. 9, p. 36I, I9I7.

${ }^{2}$ Comment on manuscript of Professional Paper No. 7 I, p. 387 .

${ }^{3}$ Gale, Hoyt S., Rock Phosphate Near Melrose, Montana, U. S. Geological Survey, Bull. 470, p. 444 , I910.

${ }^{4}$ Bowen, C. F., Phosphatic Oil Shales near Dell and Dillon, Beaverhead County, Montana, U. S. Geological Survey, Bull. 66I, p. 3I6, I9I8. 
stone and chert. This formation was not studied in detail, and no fossils were obtained from it. It seems to correspond in position to the Quadrant quartzite.

"The thick sandstone (No. 3) is overlain by a few hundred feet of gray limestone, which is covered by sandy beds. Fossils obtained both from the limestone and from the sandy beds are assigned by Mr. Girty to 'the Phosphoria formation, now regarded as of Permian age.'

"The gray limestone (No. 4) is overlain by I,500 feet or more of thin-bedded pinkish limestone, in which there may be some beds of shale. Fossils obtained from the lower part of this limestone are provisionally referred by Mr. Girty to the Lower Triassic."

In the Garnet Range, a few miles east of Missoula, Montana, the Quadrant formation is described by Pardee $^{1}$ as-

" 300 feet or more of grayish-brown and yellow quartzite and red shale overlying the Madison limestone in a narrow area extending from Tenmile Creek southeastward, also west of Little Bear Creek. *** A little phosphatic sandstone overlies the quartzite in the extreme southeastern part of the area surveyed, but it dies out to the northwest. This phosphatic sandstone probably represents the Phosphoria formation."

Still farther to the northwest at Philipsburg, Montana, the Quadrant preserves the character shown near Melrose. Of this locality Calkins and Emmons $^{2}$ say the Quadrant formation is divided into two members:

Upper mainly quartzite.

Impure quartzite and quartzitic sandstone.

Calcareous shale and impure chert limestone.

Light-colored quartzite, fine-grained, thick-bedded.

Lower red magnesian limestone and shale.

Near Boulder Creek the beds are vertical and the quartzite forms prominent reefs:

The upper quartzite of the upper member is less fine-grained and is somewhat calcareous.

The middle bed is more calcareous and near Philipsburg is phosphatic.

The lower quartzite is very fine-grained and thick-bedded.

The fossils found in the calcareous beds between the quartzites are Cyathophylum? sp., Camarotochia (or Rhynchopora) sp., resembling C. sappho, Camarotoechia (or Rhynchopora) sp., resembling C. congregata.

Dr. Girty ${ }^{3}$ says of the fossils:

"These fossils must be Pennsylvanian or Permian. The presence of phosphate strata at this horizon suggests the Permian (?) phosphate beds of southeastern Idaho (Phosphoria formation), but the fauna is different. Mr. Gale's suggested correlation of the red lower members of the Quadrant with the Morgan formation of northeastern Utah, as given below, is rather confirmed than otherwise."

${ }^{I}$ Pardee, J. T., Ore Deposits of the Northwestern Part of the Garnet Range, Montana, U. S. Geological Survey, Bull. 660, p. 167, 1918.

${ }^{2}$ Calkins, F. C., and W. H. Emmons, U. S. Geological Survey, Philipsburg Folio, No. I96, p. 8, I9I 5 .

${ }^{3}$ In Philipsburg Folio, p. 8. 


\section{Calkins and Emmons continue:}

"The kinds of rocks are the same in the Philipsburg section as in the typical Quadrant of the Threeforks and Yellowstone National Park region, although the sharp division into a quartzite and a shaly member does not there seem possible. The assignment of a Carboniferous and probably Pennsylvanian age to the upper quartzitic stratum is based on lithologic rather than on paleontologic grounds, for no fossils have been found in it. The upper quartzite was included in the formation primarily because of its resemblance to the lower. Support is lent to this part of the correlation, however, by the opinion of Hoyt S. Gale, who in I9Io examined a section near Melrose, Montana, that is essentially similar to that of the Philipsburg quadrangle. Mr. Gale considers the lower and purer quartzite equivalent to the Weber quartzite of Utah, and the higher beds here included in the Quadrant as equivalent to the Park City formation of Utah. One reason for this correlation is lithologic resemblance, but a stronger one is the occurrence of a phosphate bed in the Melrose section corresponding to one in the Utah and southern Idaho sections. This phosphate lies between the two quartzitic strata and has been found at this horizon on Flagstaff Hill since the geologic survey of the quadrangle was made. The lower shaly member may have its equivalent in the Morgan formation on Utah or in similar rocks found locally in the base of the Weber quartzite."

Under the description of the geologic history of the region, Calkins and Emmons remark upon the Upper Pennsylvanian:

"The quartzites of the upper part of the Quadrant are probably beach deposits, superposed on the fine-grained rocks of the lower member after an interval of erosion, for continuous deposition would have been recorded by a gradual instead of an absolutely abrupt lithological transition. It therefore may be supposed that the inland sea of early Quadrant time was filled or upheaved and its bed, after a brief period of erosion, again invaded by the sea, whose advancing margin gradually covered the surface with a layer of beach sands. An interlude in these conditions is represented by the calcareous and phosphatic beds between the quartzite strata. The carbonate and the oolitic phosphate of lime are presumably chemical precipitates, and are most likely to have been formed in a shallow inclosed sea. The wide expanse and the unbroken continuity of the phosphate beds in this region indicates that the sea extended continuously over a large part of Montana, Idaho, Utah, and Wyoming."

In going directly north from the Yellowstone Park region, the type locality of the Quadrant formation, into Montana, the change in the deposits of the horizon are more abrupt than in going toward the northwest. This is probably due to the northwestward trend of Rocky Mountains at this point.

In describing the horizon north of the Little Belt Mountains, Weed writes as follows: ${ }^{1}$

"Quadrant formation.-This formation, named from its prominence in Quadrant Mountain in the Yellowstone Park, varies in character and increases in thickness from the southern exposure in the canyon of Sixteenmile Creek northward. The southern areas of this quadrangle show a series of beds 230 feet thick.

${ }^{1}$ Weed, W. H., Little Belt Mountains Folio, No. 56, U. S. Geological Survey, p. 2, I899. 
The upper layers are compact, hard, pink, and cream-colored quartzites, with occasional intercalated beds of limestone. The base consists of 80 feet of impure limestones with interbedded red magnesian shales that are soft and weather readily, their red muds staining the harder rocks.

"In going northward the formation changes greatly in character and thickness. In the Little Belt Range the quartzites disappear and the most characteristic feature is the presence of a shale horizon-the Otter shale-whose vivid green color makes it conspicuous wherever exposed. At the same time the formation becomes of a variable nature. Limestones, sandstones, and shale beds appear, but are not persistent. On the Judith River the base of the formation consists of the red Kibbey sandstone, which frequently contains beds of gypsum. The thickness of the formation is nearly I, 400 feet at this locality, while it is but 400 feet north of Castle Mountain. The limestones carry abundant fossil remains, fixing the age as lower Carboniferous. $* * *$ The region was probably elevated above the sea at the close of the Quadrant stage."

In the Fort Benton quadrangle, the quartzite has almost entirely given place to shales and limestones. Weed says of the horizon: ${ }^{1}$

"Within the limits of this quadrangle the Quadrant formation is a variable sequence of sandstones, shales, and limestones. The lowest beds are reddish and yellow clayey sandstones, often holding interbedded layers of gypsum and constituting the Kibbey sandstone. These are overlain by the Otter shales holding interbedded limestones. The shales are dark gray or purplish near the base, becoming a bright coppery-green higher in the sequence. The interbedded limestones are very seldom more than a foot or two thick, are frequently oolitic, and carry fossils of lower Carboniferous types.

"[The Quadrant formation] shows a very decided change of conditions of deposition, indicating a rising of the region, with shore and estuarine deposits which preceded the emergence of this tract above the sea. The change from pure limestone to red sandstones with gypsum beds and limey shales is abrupt, but the Quadrant contains also several beds of very pure limestone.

“*** though there is a marked change in the character of the forms of life, there is little change in the character of the beds between this and that of the overlying Ellis formation, whose fossils are of the Jurassic age."

Beyond Philipsburg and Fort Benton, Montana, there are no reported exposures of any formations that can be at all closely correlated with the Weber horizon, but as it has been shown that in this region the Weber is becoming more of an offshore formation with increasing limestone and is the uppermost Paleozoic exposed, it is possible to at least trace the uppermost Paleozoic farther to the north and west. The condition along the boundary between the United States and Canada is condensed from Daly on pages I I I-I78, and this area of limestone and quartzite of upper Pennsylvanian age is with little doubt to be correlated in a broad way with the Cache Creek series of British Columbia and as far north as the Yukon Territory and with the similar deposits of Alaska.

(j) Conditions on the Pacific Coast.-On the west side of the western cor-

${ }^{1}$ Weed, W. H., Fort Benton Folio, No. 55, U. S. Geological Survey, p. 2, 1899. 
dillera of the United States a few areas show the condition during the uppermost Pennsylvanian time.

In California two formations have been recognized as PennsylvanianRobinson and Calaveras.

The Robinson formation is described by Turner" as "sediments and trachyte tuffs," with fossils of upper Carboniferous age, and by Diller ${ }^{2}$ as containing shales, conglomerate, tuff, and sandstone, of which the last two are the most important. The sandstone is a purplish rock of great variability. One-fourth of a mile south $50^{\circ}$ west of Robinson's, in Genesee Valley, it becomes for a short distance an arenaceous limestone.

J. P. Smith ${ }^{3}$ considers this as equivalent to the Carboniferous portion of the Pitt formation of Shasta County.

In northern California, north of the fortieth parallel, the upper Pennsylvanian is represented by the McCloud limestone and the Pitt shales. Smith ${ }^{4}$ gives the following table of the formations of Shasta County:

\begin{tabular}{|c|c|c|c|}
\hline \multirow{4}{*}{ Carboniferous } & Middle Triassic. & \multirow{2}{*}{ Pitt formation. } & Pitt shales. \\
\hline & \multirow{2}{*}{ Upper Carboniferous. } & & $\begin{array}{l}\text { McCloud shales. Siliceous and calcareous } \\
\text { shales and conglomerates, with upper } \\
\text { carboniferous fauna at base, I,00o feet. }\end{array}$ \\
\hline & & \multirow{2}{*}{$\begin{array}{l}\text { McCloud for- } \\
\text { mation. }\end{array}$} & $\begin{array}{l}\text { McCloud limestones. Massive limestone } \\
\text { and marbles of the McCloud River, } \\
\text { rich in corals and brachiopods, } 2, \text { ooo feet. }\end{array}$ \\
\hline & Lower Carboniferous. & & Baird shales. \\
\hline
\end{tabular}

The McCloud shales are correlated with the Robinson formation, and both have been separated off as the Nosoni formation.

The McCloud limestone is described by Diller ${ }^{\circ}$ as a dark gray sand, massive below and lighter colored and somewhat thinner above, with many nodules of chert and sheets of gray chert, often containing silicified fossils.

The McCloud limestone, according to J. P. Smith, ${ }^{6}$ is about-

" 2,000 feet in thickness, uniform in bedding, and very siliceous in places. Some few beds are altered to a crystalline marble, but in the main the series is made up of a fine-grained hard gray limestone. $* * *$ The McCloud limestone is probably equivalent to the Caribou formation of Plumas county. But J. S. Diller thinks they belong to a lower horizon than that assigned them by the writer. The Robinson beds of the Taylorville section are probably higher up in the section, but nevertheless the McCloud limestone is, in part at least, equivalent to the Coal Measures."

1 Turner, H. W., Bidwell Bar Folio, No. 43, U. S. Geological Survey, 1898.

${ }^{2}$ Diller, J. S., Geology of the Taylorsville Region, California, Bull. Geol. Soc. Amer., vol. 3, p. $374, \mathrm{I} 892$.

${ }^{3}$ Smith, J. P., The Metamorphic Series of Shasta County, California, Jour. Geol., vol. 2, p. 602,1894 .

${ }^{4}$ Idem.

${ }^{5}$ Diller, J. S., Redding Folio, No. I38, U. S. Geological Survey, 1906.

${ }^{6}$ Smith, J. P., The Metamorphic Series of Shasta County, California, Jour. Geol., vol. 2, pp. 599 and 60I, I894. 
The McCloud shales (Nosoni formation) are provisionally correlated with the upper Hueco by Girty, and Schuchert ${ }^{1}$ remarks: "It also seems to correlate with the Schwagerina zone of the Russian geologists. This zone is just below the Permo-Carboniferous or Artinskian."

They are described as the lower part of the Pitt formation by J. P. Smith, as follows: ${ }^{2}$

"The Pitt formation overlies conformably the McCloud limestones, and consists roughly estimated of about 3,000 feet of siliceous and calcareous shales, conglomerates and tuffs. $* * *$

"The oldest fossiliferous strata of the Pitt formation are of Upper Carboniferous age. $* * *$ The rock is a dark calcareous argillite. $* * *$ These beds are the probably equivalents of the Robinson beds of the Taylorsville region, and of the Little Grizzly Creek beds, Plumas County, which seem to form the top of the Carboniferous formation. The boundary of these Carboniferous argillites could not be found, but they probably make up the lower thousand feet of the Pitt formation."

Diller, in the Redding Folio, says that the McCloud limestone was formed by quiet sedimentation during Mid-Carboniferous time, that oscillations began and the McCloud was succeeded in Nosoni (late Carboniferous) by shales and sandstones with increasing quantities of tuffs and volcanic flows. The period of deposition was terminated in this locality by an uplift and extensive volcanic activity.

In the Klamaths proper the McCloud is a fine-grained limestone, very siliceous in places; it is upper Carboniferous and equivalent to the Caribou of the Plumas County region.

The Nosoni shale is continued above the McCloud and is overlain by the Hall City limestone of Permian age.

Girty $^{3}$ correlated the McCloud limestone with the Hueco. Both Girty and Schuchert have suggested that the same sea which deposited the McCloud extended into southwestern British Columbia (Cache Creek), and into Alaska as far as the Chicagoff Islands.

The deposition of the Nosoni was terminated all along the Pacific coast by an elevation which was the culmination of the volcanic activity which furnished the tuffs and flows of the Nosoni. This elevation probably represents a considerable interval of time before the deposition of the Triassic. It was in all probability a part of the greater movement which is traceable from Alaska southward, in elevation and extensive volcanic activity both subaerial and submarine (southern Alaska) as far as the Redding, California, quadrangle.

\footnotetext{
${ }^{1}$ Schuchert, Chas., Paleogeography of North America, Bull. Geol. Soc. Amer., vol. 20, p. 573 , 1910.

2 Smith, J. P., loc. cit., p. 601.

${ }^{3}$ Girty, Geo. H., The Relations of Some Carboniferous Faunas, Wash. Acad. Sci., vol. 7, p. I6, I905.
} 
North of the Klamath Mountains no record of the upper Paleozoic is left in Oregon, and it is not again visible until the Snoqualmie quadrangle is reached going northward.

Pardee ${ }^{1}$ reports a "series of sediments and lavas that have been more or less metamorphosed and include shale, slate, argillite, schist, quartzite, conglomerate, and greenstone." He states:

"These rocks are most extensively developed in the northeastern part of the reservation (Colville Indian Reservation), where, underlying most of the Covada mining district, they oceupy a belt about 8 miles wide that extends from the head of Ninemile Creek east to the Columbia River and thence north to the reservation boundary. Because no well-marked stratigraphic break was seen in these rocks, because sufficient fossils upon which to base time divisions were not found in them, and because they are most conveniently mapped and described as a unit, the name Covada, which has been applied to that portion exposed in the vicinity of Covada settlement, may be extended to the metamorphic series as a whole, which is here designated the Covada group."

Pardee suggests the probable equivalence of the Covada group with Cache Creek and its equivalents of the Boundary Survey and northern British Columbia and with the McCloud and Nosoni formations. He says:

"Thus a chain of Carboniferous roeks of generally similar lithology, extending from Alaska to California, seems fairly well established, and the position of the Colville Reservation strongly sugests that the Covada group is one of the links."

A suggestion of Paleozoic in Oregon near Grant Pass, in the south-central part, is given by Diller and Kay. ${ }^{2}$ Here a few poor fossils (crinoid stems) were found in limestone lentils interbedded with clay slates, siliceous slates, and tuffs. The bulk of the limestone is Devonian, as shown by the fossils, but the third belt of the description carrying the crinoid stems is possibly Carboniferous, possibly Triassic. It is unconformable with the overlying Jurassic. (See also Oregon Bureau of Mines and Geology and a Bibliography of Oregon Geology, etc., Oregon University Bulletin, new series, vol. Io, No. 4, I9I2.)

In the Snoqualmie quadrangle, Smith and Calkins ${ }^{3}$ recognized three layers among the metamorphic rocks, which are composed of sediments and volcanics: they are the

Peshastin.

Hawkins.

Easton schist.

These are reported to be strikingly similar to Paleozoic rocks in California, of the Blue Mountains in Oregon, and in the Okanagon Valley of Washington.

${ }^{1}$ Pardee, J. T., Geology and mineral resources of the Colville Indian Reservation, Washington, Bull. U. S. Geological Survey, No. 677, I918.

${ }^{2}$ Diller, J. S., and G. F. Kay, Mineral Resources of the Grant Pass Quadrangle and Bordering Districts, Oregon, U. S. Geological Survey, Bull. 380, p. 5I, I909.

${ }^{3}$ Smith, Geo. O., and F. C. Calkins, Snoqualmie Folio, No. I39, U. S. Geological Survey, I906. 
The inference drawn from this is that during a portion of Paleozoic time the Pacific Coast region from British Columbia to California constituted a single geological province. This became land in the Mesozoic and was already uplifted and folded before the great intrusions which metamorphosed the rocks.

Farther north in Washington, in the Republic mining district, Paleozoic rocks are again shown in a considerable exposure. Umpleby, ${ }^{1}$ discussing this area, says:

"The oldest rocks exposed in the district are the metamorphic equivalents of a great series of shales, sandstones, limestones, and lava flows which are of Paleozoic age, and are provisionally assigned to the Carboniferous. After the deposition of this series, the area passed through a long period of crustal disturbance which, although not developing sharp folds, metamorphosed the beds and raised the area far above sea-level. Either during this period of crustal disturbance or shortly thereafter great batholithic masses of grandiorite were intruded into the Paleozoic series. ***

"The Paleozoic rocks are very uniformly but not intensely metamorphosed. True schists are not common, and in many instances the limestone has not been changed to marble. Nevertheless, the series has been so disturbed that a given set of characteristics seldom persists for more than a short distance in any direction. Neither bottom nor top of the series was found.

"Black carbonaceous argillite is the predominant rock type, although bluishgray nonfossiliferous limestones have a wide development. Massive gray quartzites were noted in one exposure southwest of Republic. Porphyries of intermediate and basic composition are found both as dikes and sills, apparently intruded into the series before its metamorphism. The age relations of the various phases of the series are not obvious from studies in the Republic area, but to the north, at Phenix, British Columbia, LeRoy reports a section including all the above types of rocks, which he divides into three parts with an unconformity between the upper two. His section places the argillites in the upper part, separated from the limestones and tuffs (no tuffs of this age were noted at Republic) by a pronounced unconformity, while the lower member is quartzite with intruded dikes and sills of basic porphyrites. The Paleozoic beds are folded and metamorphosed, and are in marked contrast with the overlying Tertiary series, in which folding is less marked and the beds are not metamorphosed.

"It is not possible, on the strength of facts now known, to assign this formation to a definite place in the Paleozoic series. Near Republic the formation carries certain fossils, not well preserved, but which seem to be crinoid stems. In an exposure of limestone near the top of Buckhorn Mountain, in the northwest part of Republic quadrangle, several fossil crinoid stems were found which are not out of harmony with a provisional assignment to the Carboniferous. These remains, together with the lithologic characteristics of the series, suggests a correlation with the Cache Creek series of Dawson, which is of Carboniferous age.

1 Umpleby, J. B., Geology and Ore Deposits of Republic Mining District, Washington Geological Survey, Bull. I, p. I5, 1910. 
On lithologic grounds, however, it is thought that rocks of more than one age are present."

Knopf ${ }^{1}$ suggests the name Onwenyo limestone for a small mass of limestone appearing on the slopes of the Inyo Range facing Owens Valley, which he considers as perhaps equivalent to the "Upper Coal Measure limestone" of Hague's Eureka report. This formation "consists in the main of massive, grayish, crystalline to compact limestones. The 2 -foot basal bed is a bluegray compact limestone fossiliferous from the contact and carrying irregular lenses and stringers of sandstone whose grains are apparently derived from the Reward below. Here and there through the Onwenyo, particularly in its upper third, are layers carrying rounded chert pebbles. The higher beds are fairly massive and break down in large blocks on weathering. The limestones as a whole are bluish gray to dark in color, compact to crystalline in texture, and carry abundant fossil remains." The fossils suggest the Spiriferina pulchra fauna, which is "more or less characteristic of the Phosphoria formation of Idaho, the Park City formation of Utah, and the Embar formation of Wyoming." (Girty in Knopf's paper, page 44.) Girty's advice is: "You had best refer your collection to the Permian and correlate it with the Park City, Phosphoria, and Embar, though the Park City contains some Pennsylvanian and the Embar contains Pennsylvanian, Permian, and Triassic."

This connects the upper Paleozoic of the west coast of the United States with the Cache Creek series of the international boundary and probably through that series with the northern deposits of Montana, Idaho, and thence south.

\section{B. PERMO-CARBONIFEROUS OF NEW MEXICO.}

The southernmost extension of the Permo-Carboniferous beds of the Basin Province is exposed in the Rio Grande Valley. As far south as Alamogordo red beds occur which can be traced through the State north nearly to the north line. These have been included in the Manzano group, which in general includes the

San Andreas limestone.

Yeso formation.

Abo sandstone.

These deposits were described by Lee and Girty ${ }^{2}$ in I909. The Abo is the lowest.

(Page I2.) "It consists of coarse-grained sandstone, dark red to purple in color and usually conglomeratic at the base, with a subordinate amount of shale,

${ }^{1}$ Knopf, Adolph, A Geological Reconnaissance of the Inyo Range and the Eastern Slope of the Southern Sierra Nevada, California, Professional Paper No. I Io, U. S. Geological Survey, I9I8.

${ }^{2}$ Lee, W. T., and G. H. Girty, The Manzano Group of the Rio Grande Valley, U. S. Geological Survey, Bull. 389, I909. 
which attains prominence in some places. This sandstone, together with the overlying gypsum, apparently constitutes Herrick's 'Permian.' In the classification here adopted the upper limit of the Abo formation is drawn below the gypsum for the obvious reason that in many places the overlying or Yeso formation contains beds of gypsum and gypsiferous shale at several horizons, through a thickness in some places of $\mathrm{I}, 000$ feet or more.

"Yeso formation.-The Yeso formation *** lies with apparent conformity upon the Abo sandstone, and consists of I,000 to 2,000 feet of sandstone, shale, earthy limestone, and gypsum. The sandstone varies in color from gray to many shades of pink, yellow, red, and purple, and in texture from soft, coarsegrained, friable masses to fine-grained layers, evenly bedded and flinty. The shales, frequently gypsiferous, are soft, pink to yellow in color, and beds of massive white gypsum IOO to 200 feet thick occur in many places.

"San Andreas limestone._*** It consists essentially of massive limestone, which is often cherty and poorly fossiliferous, although several localities were found where fossils are abundant.

The discovery by Case of Permian vertebrates in the Abo sandstone northeast of Socorro, New Mexico, ${ }^{1}$ similar to or identical with those occurring in the El Cobre Canyon and in the Arroya de Agua, Rio Arriba County, New Mexico, shows that these deposits belong in the Basin Province.

Whether it will later be proven that the Abo is continuous with the red sandstone of the Pecos Valley around the southern side of the Guadalupe range is uncertain, but there can be little doubt that the beds occupy an equivalent or somewhat lower position. Williston ${ }^{2}$ and Williston and Case $^{3}$ have asserted their belief based on the stage of development of the forms, found, that the beds of Rio Arriba County, are younger than those of Texas, and later Williston ${ }^{4}$ expressed his belief that the El Cobre beds of New Mexico are the equivalent of the Wichita beds of Texas. Beyond this there is no evidence of their relative position.

Lee and Girty ${ }^{5}$ believe that these beds are the equivalent of the Texas beds. They say that an uplift occurred in the Rio Grande Valley immediately preceding the deposition of the Manzano beds; then the red beds of the lower part of the Manzano group were deposited, which are equivalent to the red beds of eastern Colorado and to the red beds of Texas.

To the southwest the lower part of the Manzano group is apparently lacking. Darton has described the Gym limestone which he regards as the upper part of the Manzano, in two papers. In I916 he said: ${ }^{6}$

\footnotetext{
1 Case, E. C., Further Evidence Bearing on the Age of the Red Beds in the Rio Grande Valley, New Mexico, Science, vol. 44, pp. 708-709, I916.

${ }^{2}$ Williston, S. W., The Permo-Carboniferous of Northern New Mexico, Jour. Geol., vol. $\mathrm{XX}, \mathrm{pp} . \mathrm{I}-\mathrm{x} 2, \mathrm{I} 9 \mathrm{I} 2$.

${ }^{3}$ Williston, S. W., and E. C. Case, Permo-Carboniferous Vertebrates from New Mexico, Carnegie Inst. Wash. Pub. No. I8I, I9I3.

${ }^{4}$ Williston, in C. R. Stauffer, Divisions and Correlations of the Dunkard Series of Ohio, Bull. Geol. Soc. Amer., vol. 27, p. 88, 1915.

${ }^{5}$ Lee, W. T., and G. H. Girty, The Manzano Group of the Rio Grande Valley, U. S. Geological Survey Bull. 389 , I909.

- Darton, N. H., Geology and Underground Waters of Luna County, New Mexico, U. S. Geological Survey Bull. 6r8, 1916.
} 
(Page 35.) "In the central and southeastern portions of the Florida Mountains and the central portion of the Victorio Mountains and extending part way around the north end of the Tres Hermanas Mountains there is a thick series of limestones to which it is proposed to apply the name Gym limestone. ***"

This limestone appears on the top of peaks and fault blocks in scattered areas through the county. It is the uppermost formation of the Paleozoic.

(Page 36.) "The formation consists chiefly of limestone, in greater part massively bedded, of light-gray color, and showing a brecciated structure in many beds. In Gym Peak and vicinity the lower member is dark and the one next above it is much lighter in color, with an abrupt change from one to the other, and the thickness remaining in this area and west of the peak is at least 700 feet. In the canyon I mile southeast of Gym Peak limestone apparently in the middle of the formation dips steeply southeastward under 80 feet of dark-gray fissile shale which is traceable for about half a mile and again appears along the great fault on the trail a short distance west of Gym Peak. This black shale is overlain on the east by cherty limestone containing abundant Manzano fossils, and this limestone is finally cut off by the great fault which crosses the mountain. ***"

In one locality in the Tres Hermanas Mountains the Gym limestone passes under "gray quartzite, which is the highest member exposed."

The fossils studied by Girty indicate that the relation is with the Manzano, but some of the gastropods indicate the Hueco. Later Darton ${ }^{1}$ said of the Manzano group:

(Page 53.) "The Manzano group is represented in central and northern New Mexico by the Gym limestone, which crops out extensively in the Florida Mountains, type locality, and also in the Victorio Mountains. * * * The Gym limestone also appears extensively in the Tres Hermanas Mountains, where it is uplifted and cut by porphyry, and it also crops out in a few small hills rising out of the desert in the south-central part of the county. The formation has not been recognized outside of Luna County, although doutbless it is represented in the Manzano and Hueco sections in other areas. * * * "

"The formation consists almost entirely of light-gray limestone, mostly massive and in part brecciated. An 80-foot member of dark-gray shale is apparently included on the southeast slope of the Florida Mountains, but this may be the Percha shale overlapped, or faulted into its present position. In the Tres Hermanas Mountains part of the Gym limestone is metamorphosed to white marble and there is included a member of 50 to 60 feet of gray to reddish quartzite. ***',

"In the San Andreas and Sacramento mountains and farther north in New Mexico the supposed equivalent of the Gym limestone is separated from the Magdalena group by a thick series of red beds (Abo sandstone), but these beds are lacking in the southwest corner of the State and also in the region near and east of El Paso.

(Page 55.) “*** Pennsylvanian and Permian time is represented in the main by deposits of the Magdalena and Manzano groups and the Hueco and Gym limestones. The Hueco and Gym are contemporaneous, at least in part, with

${ }^{1}$ Darton, N. H., A Comparison of the Paleozoic Sections in Southern New Mexico, U. S. Geological Survey, Professional Paper No. 108-c, 1917. 
the Manzano group, which includes 500 to I,00o feet of red beds (Abo sandstone) that thin out to the south."

That the red beds of the Rio Grande Valley and western New Mexico and Arizona, with their associated rocks, belong in a distinct faunal and depositional province (the Basin Province), the author has already attempted to demonstrate (Carnegie Inst. Wash. Pub. No. 207, I9I5), but the relation of the Guadalupian and the overlying beds to the uppermost beds of Kansas (Kiger of the Cimmaron series), Oklahoma (Quartermaster and Whitehorse), is a matter of uncertainty. Girty, if I understand him correctly, would place the Capitan limestone entirely above the Whitehorse beds of Oklahoma, placing them in the Artinskian or Artinskian and Permian; while Beede regards the distinction in fauna as due to environmental conditions and regards both as Permian.

Girty discusses the relations at some length in his monograph upon the Guadalupian fauna. ${ }^{1}$ On page 48 he says:

"In passing northward it appears that the Hueco beds, typically consisting of dark limestones, change their color and lithology, and are represented by red beds interspersed with limestones. In the Grand Canyon section they appear as the Aubrey sandstone and limestone, while in Utah the Weber quartzite seems to be equivalent to them. These correlations are at present provisional. With still greater reserve are the red-beds faunas of Wyoming correlated with the Weber on the one hand and the upper part of the Kansas section on the other. Their relationship with the eastern fauna is far stronger than with the western. At present I see no evidence of their being younger than the Weber, but they may be older. Conservatively they may be placed in the same epoch. If we accept this correlation of the Hueco formation with the Gschelian on the one hand and the Kansas Carboniferous on the other, the Guadalupian would consequently correspond to the Artinsk or to the Artinsk and the Permian.***"

(Page 5o.) "It seems to me more probable that the upper Carboniferous of the Mississippi Valley represents not the Pre-Hueconian alone of the transPecos and New Mexico section, but the pre-Guadalupian as a whole * * *."

In another place ${ }^{2}$ he says that the fauna of Hueco may be equal to eastern faunas, of the Mississippi Valley, but that the Guadalupian fauna certainly can not, though the difference may be due to environmental conditions.

"Provisionally I am regarding the Guadalupian as younger than any known faunas of the eastern region, thus interpreting the faunal differences of the Hueconian when compared with the Pennsylvanian and Permian of the East, as due to environment rather than to time."

Beede has long contended that the fauna of the upper red beds of Oklahoma (Whitehorse) is truly Permian and equivalent in time to the Guadalupian. In his review of Girty's monograph he says:3

${ }^{1}$ Girty, G. H., The Guadalupian Fauna, U. S. Geological Survey, Professional Paper No. $58,1908$.

${ }^{2}$ Girty, Geo. H., Outlines of Geologic History, University of Chicago Press, pp. I33, I34, I9ro.

${ }^{3}$ Beede, J. W., Jour. Geol., vol. xviI, p. 677, I909. 
"It would seem that the general physical conditions prevailing throughout the world at the beginning of and during Permian time must be taken into account in making broad correlations of Carboniferous and Permian faunas. The significance of the evolution of a provincial fauna in a great epicontinental sea, covering 200,000 or 300,000 square miles, with inadequate and perhaps only intermittent connection with the open sea of the continental shelves in America, should be as great as the evolution of a fauna in the Uralian region. This significance is increased when it is taken into consideration that both developed during the time when the water was being drawn from the shelves of both continents and the areas of the inland seas were being greatly reduced.

"In this light the parallelism in the nature of the deposits of the two regions, accompanied by a like parallelism of faunal changes, is of fundamental importance, and deserves a larger consideration than Dr. Girty has given it. For instance, the introduction of new faunal elements, the sudden and nearly complete disappearance of the Fusulina, and the occurrence of Schrwagerina bear the same relations to the early gypsum deposits and the development of the Red Beds, in the Kansas section, as they do in the eastern part of European Russia. If I read the stratigraphic account of the Guadalupes aright, it seems that the general considerations of the later Permian apply to them likewise. The unconformity, if such it be, carrying away the Capitan limestone from the flanks of the mountain of which it forms the top, and over the unconformity the deposition of the Castile gypsum, Rustler formation, and Red Beds, strongly suggest that the Guadalupe region was similarly affected with the region to the northward so far as a general Permian emergence is concerned. In this light the Guadalupian faunas must be largely contemporaneous with the Permian faunas of America and Eurasia. In the eyes of the reviewer, judging from figures and descriptions only, there is where their faunal relationships would also place them.

"The point is made that the faunas are so different that, if they are contemporaneous with those of the Mississippi Valley-of which Dr. Girty seems to be doubtful--they could not both be covered by a single general term (like Permian?) for their designation. That they are quite distinct from anything yet brought to light on the continent will be granted at once by anyone familiar with the subject. The one is a cosmopolitan, open-sea, coastal-shelf fauna, while the other is a more isolated epicontinental sea fauna rather thoroughly separated from its neighbor on the south and perhaps belonging to a different climatic zone. Should they prove to be equivalent in time, I see no reason why they might not be covered by a single term of ordinal rank, their local geologic designations being sufficient to differentiate them.

"That it was impossible for the Guadalupian and Mississippi Valley clearwater faunas to intermingle to a considerable extent after the time represented approximately by the Topeka limestone, unless by a circuitous route, no one acquainted with the geology of the intervening region would hesitate to state."

Beede's explanation of the impossibility of the intermingling of the waters of western Oklahoma which were already depositing red beds and the clear waters of the sea which deposited the Capitan limestone are quoted on page I0o. To the author there is considerable difficulty in accepting either of these explanations.

The red beds of the Pecos Valley are in all probability of equal age with, and the same in stratigraphic position as, the uppermost red beds of southern 
Texas, which are, at least, no higher than the Double Mountain, and these, with the Castile gypsum and Rustler limestone, lie upon an erosion surface which truncated the Delaware limestone and (in all probability) the Capitan limestone, but they are below the Greer and Quartermaster (Whitehorse) of western Oklahoma. Beede says of the Guadalupian and overlying beds: ${ }^{\mathbb{1}}$

"The stratigraphic relationships of these Permian beds are peculiar and interesting. They are brought to the surface by a westward-facing fault-scarp as it dies out into a fold to the south. Other mountains occur to the west and northwest with older faunas, and only in this one locality is the nearly full section of the Guadalupian rocks shown. The Capitan limestone (white Permian limestone of Shumard) is I,700 or I,800 feet in thickness. Below this is the Delaware Mountain formation, composed of dark limestones and sandstones with a black limestone $200+$ feet thick beneath it, giving, all told, some 2,500 feet to this formation and a total of about 4,000 feet to the whole Guadalupian section as shown at the southern extremity of the mountains. The stratigraphy was largely worked out by Richardson. To the east, on the dipslope of the mountain, the Capitan limestone is wanting. An erosional unconformity is found on the Delaware Mountain formation upon which rests the Castile gypsum. The exposures of the region show 50 or 60 feet of it and a well at Rustler Spring penetrated it to a depth of 300 feet. To the east, and upon this, lie the Red Beds."

\section{Richardson says: ${ }^{2}$}

"The Castile gypsum along its western outcrop lies in little knolls and valleys of the underlying Delaware Mountain formation, indicating an erosional unconformity. Another evidence of unconformity at the base of the gypsum consists in the absence of the Capitan limestone. It appears that either the gypsum was deposited at or near the top of the Delaware Mountain formation as a lens which did not extend westward to intervene between the Delaware Mountain formation and the Capitan limestone in the Guadalupe Mountains, or that erosion removed the former southwestward extension of the limestone (the thickness of which is unknown) before the deposition of the gypsum. The former supposition necessitates the correlation of the Rustler formation, which overlies the gypsum, with the upper part of the Delaware Mountain formation or with the Capitan limestone. But there is little to support this interpretation, and it is tentatively assumed that the Castile gypsum and the Rustler formation were formed after the deposition and erosion of a part of the Capitan limestone."

\section{PERMO-CARBONIFEROUS OF ARIZONA.}

The red Abo sandstone of New Mexico carries vertebrate fossils very similar to those from El Cobre Canyon and Arroya da Agua, and this sandstone is revealed to the west in the Jemez uplift and so carried west to the region of Fort Defiance, Arizona, whence it can be traced south to Fort Wingate in New Mexico and the Grand Canyon region. The sandstone in

1 Beede, J. W., Review of the Guadalupian Fauna by Geo. H. Girty, Jour. Geol., vol. xvIr, p. $672,1909$.

${ }^{2}$ Richardson, G. B., A Reconnaissance in Trans-Pecos, Texas, University of Texas Mineral Survey Bull. No. 9, p. 43, 1904. 
northern and central Arizona is the Moenkopie. Darton has given a general review of the Permian of this region, ${ }^{1}$ with a map of the outcrops. He describes the Moenkopie as a mass of shales and sandstones, generally of a red color and very variable in different sections - terminated at the top by a conglomerate, the Shinarump, which is considered as Triassic.

The following general section of the Moenkopie on the Little Colorado River is quoted from Ward by Darton:

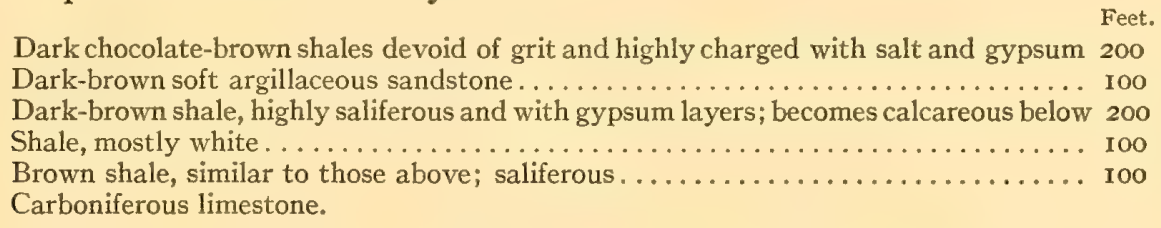

"The sandstones occur at various horizons and locally attain a thickness of Ioo feet, with more or less intercalated shale. They are mostly soft, and weather in irregular rounded ledges. The gypsum occurs largely in thin veins, crossing the strata at various angles. Toward the base of the formation the shale is calcareous and nearly everywhere includes a bed of limestone that merges into the inclosing strata."

The same formation occurs in the Zuñi Uplift, at San Jose, Ojo Caliente, and Jemez.

These beds extend westward beyond the San Francisco Mountains until the last remnants appear in small red hills between Ash Fork, Arizona, and the rim of the Grand Canyon.

A more detailed account of the Permian of northern and northwestern Arizona appears in Gregory's description of the Navajo Country. ${ }^{2} \mathrm{He}$ says on page 23 :

"In mapping the geology of the Navajo country it was found that strata of Permian (?) age are more widely extended than had previously been supposed. They occur not only in the Little Colorado Valley, but along the San Juan and at a number of localities on Defiance Plateau. In the western part of the reservation they mark the beginning of the red beds and are easily distinguished as a whole from the underlying Kaibab by abrupt changes in color and in composition."

On page 24 is given a "section of Moenkopi formation in the wall of Little Colorado Canyon, about 5 miles below Tanner Crossing, Arizona," as follows:

Shinarump conglomerate; gray and mottled, cross-bedded; pebbles of quartz, quartzite, calcareous shale, and petrified wood.

Unconformity; marked by sudden transition of shale to conglomerate and by wavy, irregular contact, including pockets in shale filled by sandstone and conglomerate.

I. Shale, red; bleached white at top, arenaceous and argillaceous, compact, hard, of microscopic

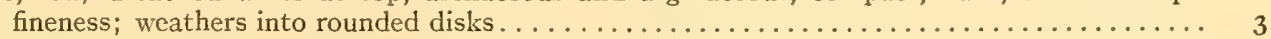

2. Shale, red-brown and gray banded, argillaceous, lenticular, with lenses of sandstone at bottom... 25

${ }^{1}$ Darton, N. H., A Reconnaissance of Parts of Northwestern New Mexico and Northern Arizona, U. S. Geological Survey Bull. 435, I9Io.

${ }^{2}$ Gregory, H. E., Geology of the Navajo Country, U. S. Geological Survey, Professional Paper No. 93, 1917. 
3. Shale, red-brown, argillaceous, and thin cross-bedded, like grass or stems of reeds arranged in

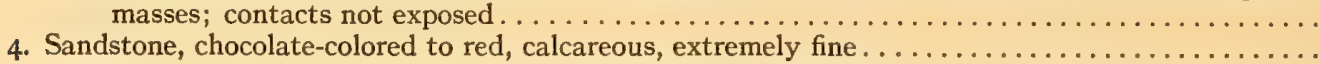

5. Shale, brown and maroon, arenaceous and calcareous, ripple-marked and mud-cracked . . ......

6. Sandstone, red-brown, massive, extremely fine-grained, micaceous . . . . . . . . . . . . . . . . . .

7. Shale, banded chocolate-colored and red-gray, arenaceous, becoming argillaceous at the top; tiny

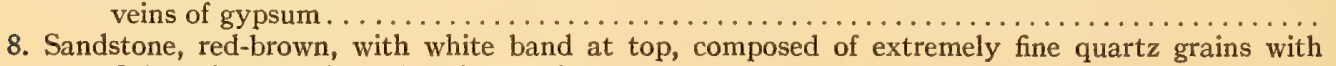

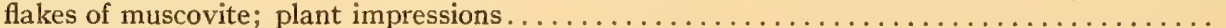

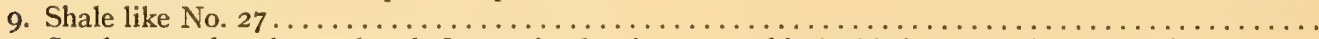

10. Sandstone, chocolate-colored, fine-grained, micaceous, thin-bedded at top; forms bench........

II. Shales, banded red of various shades and gray-green, arenaceous, argillaceous, calcareous........

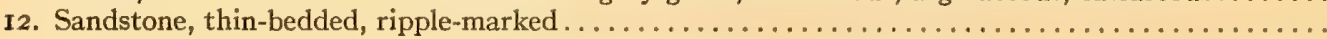

13. Shale, red-brown, with streaks of purple and green-gray and blotches of white; includes lenses of sandstone; bedding planes sun-baked . . . . . . . . . . . . . . . . . . . . . . .

I4. Sandstone, red-brown, thin-bedded, cross-bedded, marked by ripples, mud cracks, and worm casts; muscovite on bedding planes; plant impressions on lumpy uneven surfaces include striated and radiating groups. . . . . . . . . . . . . . . . . . . . . . . . . . . . . . .

i5. Shale, banded chocolate-color, red, gray, and green, arenaceous and calcareous at bottom, argillaceous at top, ripple-marked, mud-cracked, lenticular . . . . . . . . . . . . . . . . . . .

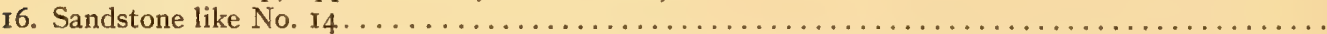

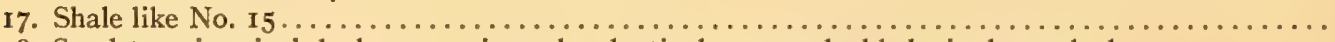

18. Sandstone in 3-inch beds, wavy, irregular, lenticular, cross-bedded, ripple-marked...........

I9. Shale, red-brown, arenaceous, calcareous, banded and lenticular; shows worm casts, sun-baked surfaces, and impressions of plants.

20. Sandstone, red-brown, thin-bedded lenticular, with bands of argillaceous and calcareous shale;

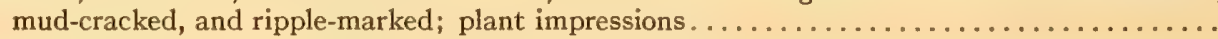

21. Shale, banded dark red, light red, and purple, with elliptical blotches of green-white, yellow-

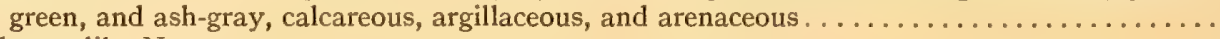

22. Sandstone like No. 20 .

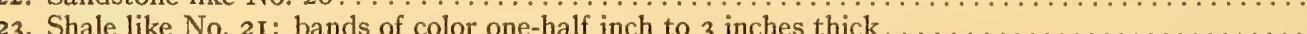

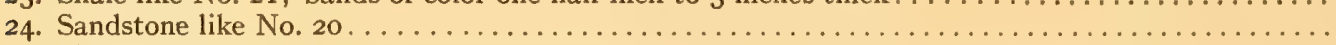

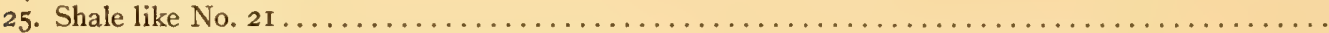

26. Sandstone, chocolate-colored, highly calcareous, with scattered limestone pebbles.............

27. Shales, chocolate-colored to red, with gray and lavender lenses; arenaceous, imbricated, ripplemarked; 15 feet from the bottom is a 6-inch bed of sandstone, and thin sandstone lenses occur throughout; the top ro feet is dark-red argillaceous shale in regular beds traversed by veins of gypsum, probably of secondary origin

28. Sandstone, chocolate-red, with streaks of maroon and purple; fine-grained quartz with calcareous cement; cross-bedding both angular and tangential; fine to medium grained; size of grain varies with each lamina. Near middle of bed are lenses of conglomerate, 2 inches to 12 feet wide, 6 inches to Ioo feet long, highly irregular in shape, and composed of chunks and slabs of argillaceous shale, sandy shale, and sandstone; muscovite abundant on bedding plane; forms vertical cliff.

29. Shales, chocolate-colored with white bands; arenaceous and micaceous strata, thin as cardboard or 2 to 3 inches thick; show ripple-marked, mud-cracked, sun-baked surfaces, curled disks,

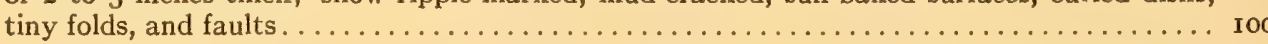

(Page 25.) "The bedding is very irregular throughout. Strata of shale and sandstone appear and disappear along the strike, and individual laminæ within the beds are markedly discontinuous. Arenaceous beds prevail, typical clay shales are very rare, and pure limestone is absent. Mr. Heald noted that the strata became increasingly calcareous upward until bed No. 3 is reached. Gypsum in tiny horizontal and vertical seams is common. A large part of it, perhaps all, is secondary. Several small unconformities were noted, but no hiatus that necessarily involved a long period of corrasion or of weathering. Part of the color banding appears to be genetically related to conditions of deposition; much of it is better explained as due to leaching by ground water. Frequent exposure to the atmosphere as the Moenkopi beds were forming is indicated by the almost universal presence of sun-baked surfaces and ripple-marks. Plant impressions are common and appear to represent several different species." 
In discussing other sections related to this, Gregory makes frequent reference to "mud-lumps" and fragments of shale in the different layers. He also speaks of the discontinuity of the layers (p. 27): "All the beds in this section [2 miles east of Holbrook, Arizona] "decrease and increase within short distances along their strike, and most of them retain their individuality only for a few tens or a few hundreds of feet. It is difficult to locate equivalent strata in two sections measured a mile apart."

The beds are prevailingly quartz sands and the limestone present is in lumps, grains, lenses, and concretionary layers. The gypsum is very largely secondary in origin.

(Page 30.) "The Moenkopi formation is assigned to the Permian (?) on both stratigraphic and paleontologic evidence. It possesses essential unity in structure, texture, color, composition, and conditions of sedimentation. An erosional unconformity with the Kaibab limestone marks its lower limit in the Little Colorado Valley of Arizona; and though clear evidence of such relation has not been obtained in the San Juan region, the fossiliferous Goodridge beds are separated from the Moenkopi by a sharp lithologic break. The Shinarump conglomerate (Triassic) unconformably overlies the Moenkopi or the DeChelly sandstone, which is also assigned to the Permian(?). The paleontologic evidence obtained both within the Navajo Reservation and along its borders is conflicting. Fossils collected on the rim of the Little Colorado Canyon by Mr. Pogue include many fragmentary bivalves and some gastropods. Professor Schuchert reports:

"I see Bakewellia, Pinna, Schizodus, and Bellerophon. The horizon is clearly above the Pennsylvanic and is the Permic molluscan fauna devoid of brachiopods. The horizon may be high in the Permic, that is, above Lower Permic, as the term is understood in America, say about Middle Permic.'

"Fragmentary plant remains, including species of Walchia, were collected at a number of localities and in I9I3 E. C. Case and W. B. Emery, of my party, obtained determinable plant fossils from the middle Moenkopi beds 3 miles west of Fort Defiance. Regarding this collection David White writes:

"'The large fragment with closely placed lateral twigs belongs to another Walchia resembling Walchia hypnoides. It is perhaps identical with that described by Dawson as Walchia gracilis. One or two small fragments in one of the loose rock pieces agrees still more closely with Walchia gracilis. These forms of Walchia are characteristic of the Permian and are present in Oklahoma and in the Wichita formation of Texas." "

The beds of the Kanab Valley described as Permian by Walcott seem now to be very definitely assignable to the Triassic (Meekoceras beds) and equivalent to the Permo-Carboniferous of the Uintah Mountains.

(Page 3I.) "On the northern flanks of the Zuñi Mountains, near Fort Wingate, Dutton found 'several specimens of Bakewellia and an attenuated form of Myalina corresponding to the forms of the latter genus which are common in the Permian.' The description of the strata from which these fossils were obtained indicates their equivalency with the Moenkopi at Fort Defiance and elsewhere. S. W. Williston states that 'there are genuine Permian red beds' in the Zuñi Mountains and that 'a Paleozoic brachiopod was obtained by Mr. Miller in the (Moenkopi) cliffs at Holbrook.' 
"In its stratigraphic position the Cutler formation of the San Juan Mountains corresponds to the Moenkopi formation, and the two are lithologically somewhat similar."

The De Chelly sandstone.-A massive, cross-bedded sandstone peculiar to the Navajo Country is named by Gregory the De Chelly sandstone. This had previously been correlated with the Vermillion Cliffs or the Wingate sandstone.

(Page 32.) "Section of De Chelly sandstone at west entrance of Bonito Canyon, near Fort Defiance. "[Measured by K. C. Heald. Dip, $16^{\circ} \mathrm{E}$.]

"Shinarump conglomerate.

"Unconformity.

I. Sandstone, light red, fine-grained; clear-white and red rounded quartz grains; calcareous and ferritic cement; contains rare pebbles one sixty-fourth to one-sixteenth inch in diameter; massive, cross-bedded in places; weathers into rounded knobs; in two beds, 13 and 15 feet

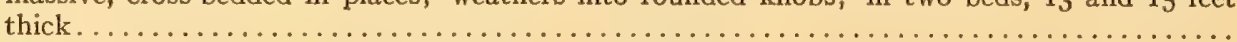

2. Sandstone, tan to brown, fine-grained; clear, well-rounded quartz; calcareous cement; many specks of limonite; even-bedded to slightly cross-bedded; hard; forms nearly vertical cliff;

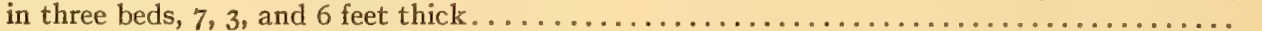

3. Sandstone, chocolate-colored to gray-brown, fine to medium grained; clear, well-rounded quartz; massive; parts of the bed show no structure; other parts cross-bedded with curved laminæ tangential to a horizontal surface; weathers in rounded bosses................. 77

4. Sandstone, chocolate-colored, shaly, largely concealed by talus. . . . . . . . . . . . . . . 27

5. Sandstone, light red, fine-grained; clear to red rounded quartz grains; bottom 5 feet thin-bedded; in the center gray, cross-bedded, resistant sheet, $\mathbf{I} \frac{1}{2}$ feet thick; remainder massive, incon-

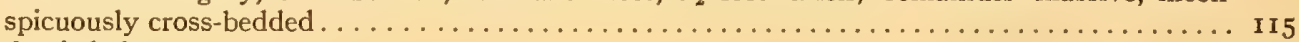
Moenkopi shales.

This section is characteristic of the De Chelly sandstone in a general way wherever it occurs. It is mentioned as occurring at Defiance Hogback, Buell Park, lower Black Creek, Canyon De Chelly, San Juan Valley in Utah, Monument Valley, etc.

(Page 33.) "Structure, texture, and composition [of De Chelly sandstone]:

"With the exception of the Navajo and Wingate sandstones, which it resembles in many physical features, the De Chelly sandstone presents the most massive strata of all the red beds. In the wall of Canyon Bonito beds 5 to Io feet thick are found near the top; but in the same locality 60 to 70 feet of strata with most obscure bedding stand vertically in the wall. At Oljeto a single bed is 85 feet thick, and in Canyon del Muerto and Canyon De Chelly there are massive beds 200 to 300 feet thick, with no definite planes of separation. Here and in Monument Valley giant slabs of rocks splitting off from the massive beds leave clean, smooth faces hundreds of square feet in area, marked only by the delicate tracery of cross-bedding laminæ.

"The De Chelly sandstone is fine-grained throughout and remarkably uniform in texture. It consists essentially of grains of two sizes-spherical grains of quartz, averaging about $0.19 \mathrm{~mm}$. in diameter and making up the bulk of the rock, and less well-rounded grains 0.5 to $0.6 \mathrm{~mm}$. in diameter. In places grains of the two sizes are intermingled, but commonly the larger grains are sprinkled over the surfaces of cross-bedding laminæ. Here and there slightly larger grains are found as lenses or strings marking cross-bedding division planes, and rarely scattered pebbles one-sixteenth to one-eighth inch in diameter are seen. White rounded quartz grains constitute about 95 per cent of the rock; red and amber 
quartz grains are also found, but the prevailing light-red to red-yellow hue of the strata is maintained chiefly by the ferritic pigment which, with calcite, constitutes the cement. Light-colored specks of kaolin are present in the hand specimen and in places give the rock an appearance of a mixture of salt and cayenne pepper. Mica and black quartz are also sparingly distributed.

"Cross-bedding is a characteristic feature of the De Chelly sandstone. Here and there the entire wall of a canyon consists of interlocking curved beds; elsewhere massive cross-bedded strata are replaced along the strike by horizontally foliated sandstones. The cross-laminæ may be a foot or more in thickness, but usually they measure less than an inch and in many places the division planes are so closely spaced that the structure is concealed, the rock surface being completely overspread by a lace-work of intricate curves. Typically the canyon walls in the De Chelly sandstone are marked by sweeping curved bands 20 to 200 feet long, tangential to a horizontal surface and flatly convex upward.

"The De Chelly sandstone is traversed by wide-spaced joints which, together with the curved cross-bedding foliation, allow the agents of erosion to carve alcoves, recesses, and tunnels in great variety and on a scale that ranges from ornamental pockets to great arched-roof alcoves in which, high on the canyon walls, are tucked away single houses or whole villages of cliff dwellings.

\footnotetext{
"Physiography of Permian Time.
}

"Gilbert conceived the whole plateau country as "covered by an inland sea entirely separate from the ocean *** from the close of the Carboniferous to the beginning of the Cretaceous.' As a result of studies in the Grand Canyon region Walcott reached the conclusion that-

"It is probable that the era of the deposition of the Permian was one of slow movement of the sea bed. Elevation and depression are indicated strongly by a marked unconformity, by erosion, in the lower portion of the upper Permian. *** The sediments are mostly detrital in character, and ripple-marks and other indications of a littoral deposit are also seen at several horizons.'

"Robinson considered the Moenkopi of the San Francisco Mountain volcanic area as 'fluviatile or lacustrine' in origin. Huntington and Goldthwait concluded that 'the Moenkopi series was probably laid down in a shallow sea where estuarine conditions may possibly have prevailed.' In a later paper Huntington ascribed these beds to alternate lacustrine and subaerial deposition incident to the expansion and contraction of waters of a lake contained within an inclosed desert basin.

"The Plateau Province during Permian (?) time was probably a region of low relief bordering the sea and having an arid climate. Over the long slopes and into the flat-floored depressions, sediments were carried from surrounding lands and deposited on flood plains, piedmont slopes, and the floors of fresh and alkaline lakes. The remarkable banding of subequal dimensions displayed in certain localities and so vividly described by Dutton indicates cycles of change of roughly equal length. In some places the sediments suggest change from subaerial to lacustrine deposition; in others marine strata are interbedded with materials of flood slopes. Deposits of gypsum alternating with ripple-marked beds of lenticular sand point to fluctuation in volume of the water contained by ephemeral lakes. Ancient playas, deltas, and flood plains are suggested by rain prints, mud cracks, and the almost universal presence of shining films of clay and mica and halite pseudomorphs that coat the planes of foliation. The general absence of fossils, other than fragments of vertebrates and xerophilous plants, is suggestive of 
continental conditions. Aridity is suggested by the presence of feldspars and by the prevailing reds and browns of the rock, which are inconsistent with the presence of ground water near the surface. The cross-bedding also points to aridity, for while angular cross-bedding of types common on alluvial plains and even on the seashore occurs in many strata, tangential cross-bedding of the eolian type is prevalent.

"Toward the end of the Permian epoch aridity reached a stage where sand dunes became a prominent feature. These are best preserved along the east and northeast sides of the area, where the De Chelly sandstone displays the record of wind work during late Permian (?) time. The walls of Canyon de Chelly consist in part of overlapping heaps of wind-blown sand now weakly cemented into rock. In the picturesque Navajo language they are 'frozen dunes.'

"The exact sequence of events during Permian (?) time has not yet been made out, but the final explanation must allow for extensive subaerial sedimentation under arid conditions and for two or more invasions of the sea. It is not necessary, however, to assume that all parts of the great area in which Permian deposits occur had the same physiographic history."

In a recent paper upon the Carboniferous of the Grand Canyon, Schuchert ${ }^{1}$ has suggested that the Kaibab limestones, the Coconino sandstone and even the upper part of the Supai formation are Permian. He says:

"That the Kaibab limestone is of early Permian age is now admitted by most American stratigraphers. This view, however, has been attained rather from its field relations than through a study of its marine fossils, for these in several forms are very much like those of the Pennsylvanian. The fauna as collected by Noble in the Shinumo quadrangle is listed by Girty and he here correlates the Kaibab limestone with the Manzano group of New Mexico. He also suggests that the Kaibab may be equivalent to a part of the Guadalupian of southwestern Texas, a formation of undoubtedly Permian age."

The remarks made by Girty scarcely seem to convey to the author so definite an idea of the Permian age of the Kaibab as is received from them by Schuchert. Girty says in a letter to Noble $^{2}$ concerning the fauna collected from the Kaibab:

"The list is typical of the fauna of the upper Aubrey, the general character of which has long been known through similar lists made up by Meek and others. I have been tentatively correlating the Aubrey with the Manzano of New Mexico and with the upper part of the Hueco formation of western Texas. Consequently, it would be older than the Guadalupe group, which overlies the Hueco formation. The fauna listed above, however, contains a number of species which are very similar to or identical with species which occur in the Guadalupian fauna, and in spite of the fact that most of the Guadalupian species have not been found in the Aubrey group, it seems less improbable than it did several years ago, when the Guadalupian fauna was under investigation, that the Kaibab limestone is of the same geologic age."

${ }^{1}$ Schuchert, Chas., On the Carboniferous of the Grand Canyon of Arizona, Amer. Jour. Science, vol. XLV, p. 347 , I9I 8.

${ }^{2}$ Girty, in L. F. Noble, The Shinumo Quadrangle, U. S. Geological Survey Bull. 549, p. 7I, 19I4. 
Schuchert regards the Coconino sandstone as, in part at least, formed from wind-blown sand derived from the north and northwest:

[This sand] "should be expected in near-shore deposits of Permian time because of the then prevalent arid climates. The eolian sand, it appears, has been blown into rivers that have brought it from a long distance to the northward and out of it in the course of transportation has been washed or blown almost all other disintegrated rock material than the quartz. ***" [The conclusion as to the origin of this sandstone reached by the writer while in the field is that it represents the material of a large delta of continental deposit laid down under constant but probably local sheets of water that were evidently entirely fresh. The Coconino may be the deposits of dunesands swept from the north into a series of basins or fresh-water lakes like the present fresh- and brackish-water lakes on the outer borders of the Nile delta.]

"That the Coconino sandstone invaded to the southward a land composed of the Supai formation is shown not only in the very different nature of these underlying strata and the sharp contact between them, but especially in the fact that the surface of the Supai has many vertical solution joints now filled with the Coconino sands."

On page $35^{2}$ Schuchert makes the suggestion that-

"It may well be that the marine Kaibab limestone and the Coconino sandstone toward the east change finally into desert dune deposits and that the De Chelly is the time equivalent of more or less of the Moenkopi, Kaibab, and Coconino formations.

"In the Upper Supai have been found plant remains which David White has determined as Callipteris cf.sp. C. conferta; Walchia cf. W.gracilis; Gigantopteris? cf. Sphenophyllum."

David White, in a letter quoted on page 354 of Schuchert's article,says :

"The condition of preservation of the fragments is so bad that caution is necessary in basing conclusions of any kind on the material submitted. However, the presence of Gigantopteris, Walchia, and probably of Callipteris, if my tentative generic identification of the latter is correct, points to the Lower Permian age of the flora. $* * *$ In any event, it appears probable that the flora, when it is better known, will be found to indicate a level not below the highest stage of the Pennsylvanian."

Schuchert notes the occurrence of these plants further east in Arizona and concludes:

"It should be noted that these fossils are found immediately above a marked erosional unconformity. If, therefore, we give full significance to this unconformity, and with it bolster up White's provisional conclusions as to the age of the plants, the upper 290 feet of the Supai are to be referred to the Permian system." 


\section{PERMO-CARBONIFEROUS OF SOUTHWESTERN COLORADO.}

The upper Paleozoic series of southwestern Colorado is generally considered as comprising the

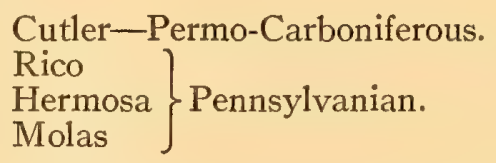

The Moenkopie of northwestern Arizona has been shown to be similar or identical in stratigraphic position with the Cutler of southwestern Colorado. The most complete description of the red-bed series in the latter region was given by Cross and Howe. ${ }^{1}$

"The Cutler formation embraces somewhat more than the lower half of the Red Beds section of southwestern Colorado. Its strata are invariably red in color and include sandstone, arkose grit, conglomerate, shale, and limestone. The maximum observed thickness is about 1,600 feet.

"The formation seems conformable with the underlying Pennsylvanian beds, but above it occurs a stratigraphic break with at least local unconformity. The base of the formation is indicated by the Pennsylvanian fossils of the Hermosa or Rico formations and in a broad way by the color line. No fossils have been found in the Cutler beds.

"Details of lithologic character.-Great variability in lithologic constitution, both vertical and lateral, is one of the most striking features of the Cutler formation. The sandstones are sometimes fine-grained and massive, but bedding is ordinarily distinct and few homogeneous beds exceed Io or I5 feet in thickness. All strata are calcareous, and the finer grained sandstones grade into calcareous shales and impure marls or into sandy limestones. These rocks are naturally more or less friable and crumbling.

"The finer-grained strata are of the strongest red color, which is due to a ferritic pigment, and they are also commonly characterized by abundant bronze or rusty mica, which renders them fissile. Clay beds are rare, as is massive limestone. Commonly the more calcareous strata are nodular or gnarly and grade into calcareous sandstones. Greenish and grayish tints are locally found in the nodular limestones and a mottling with red is common. Some of the nodular limestones appear to be intraformational conglomerates.

"The sandstones frequently grade into arkose grits and these into conglomerate. With increasing coarseness of grain the red changes to pink, and locally beds of coarse grit are gray or almost white. In other cases the finer matrix of grits and conglomerates is dark red. The cement of the strata is calcite, and most of the conglomerate and arkose beds are comparatively resistant to weathering and form prominent ledge outcrops on all steep slopes.

"The grit beds often reach 35 feet in thickness. They are variably massive, being in some places almost homogeneous from top to bottom, while more frequently divided by several thin shale or sandstone layers. Cross-bedding is almost universal. Sporadic pebbles are present in all grits, and with their increase the stratum becomes a conglomerate.

${ }^{1}$ Cross, Whitman, and Ernest Howe, Red Beds of Southwestern Colorado and Their Correlation, Bull. Geol. Soc. Amer., vol. I6, p. 46I, 1905. 
"The sandstones are mainly quartzose, the grits contain much feldspar, mica, and small pebbles like the larger ones of the conglomerates. The latter contain pebbles of granite, gneiss, and various schists, of quartzite and limestone, of greenstone and porphyry, and many of red, pink, smoky, or white quartz, part of which may come from veins.

"The pebbles are in general larger near the San Juan mountains. Boulders a foot in diameter are occasionally present, but most pebbles are only a few inches in diameter. The relative abundance of different rocks among the pebbles varies according to locality. ***

"Taking the formation as a whole, the grits and conglomerates comprise about one-third or less of its total thickness in the quadrangle surveyed, and they are distributed throughout the section. It may be assumed that as distance from the source of the pebbles increases, the formation becomes more and more a series of fine-grained sandstones and shales, with subordinate grits and conglomerates.

"Typical section composed of two sections made in the Dolores valley a few miles below Rico.

Top.

Feet.

6o. Coarse sandstone or grit, cross-bedded, locally conglomeratic, rather purplish in tone.......... Ioo

59. Calcareous sandstones, sandy shales, often micaceous and fissile, either red or mottled red and green in color . . . . ........................................ I20

58. Grit-conglomerate, of variable texture, forming ledge outcrops.................... Io

57. Fine-grained calcareous sandstones, sandy shales, with occasional thin layers of harder sandstones in red or variegated red and green $\ldots \ldots \ldots \ldots \ldots \ldots \ldots \ldots \ldots \ldots \ldots \ldots \ldots \ldots . \ldots \ldots$

56. Sandy shales, with thin sandstones at intervals; variegated or mottled dark red and light green;

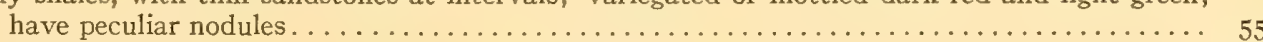

55. Grit-conglomerate . . . . . . . . . . . . . . . . . . . . . . . . . . . . . . . . . .

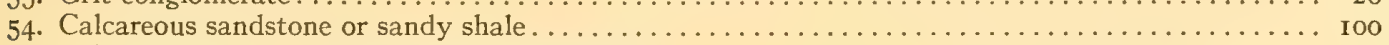

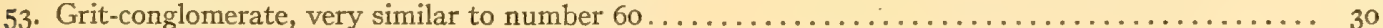

52. Friable sandstone. . . . . . . . . . . . . . . . . . . . . . . . . . 35

51. Grit-conglomerate, hard and forming a prominent ledge outcrop .................. r5

50. Sandy shales and crumbling sandstone, strong red color, partly calcareous ................. I Io

49. Calcareous shales . . . . . . . . . . . . . . . . . . . . . . . . . . . . . . . . . .

48. Coarse arkose sandstone . . . . . . . . . . . . . . . . . . . . . . . . . . . . .

47. Calcareous shales. . . . . . . . . . . . . . . . . . . . . . . . . . . . . . . . .

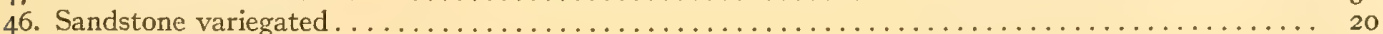

45. Calcareous shales. . . . . . . . . . . . . . . . . . . . . . . . . . . . . . . I5

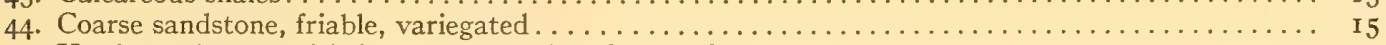

43. Hard standstone, with few small pebbles of quartzite . . . . . . . . . . . . . . . . . . I

42. Dark-red sandy shales; in places calcareous and then massive; in other parts micaceous and then

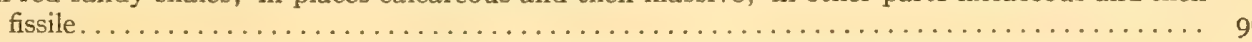

4I. Compact arkose sandstone, with few pebbles; cross-bedded; friable sandstones near top...... I5

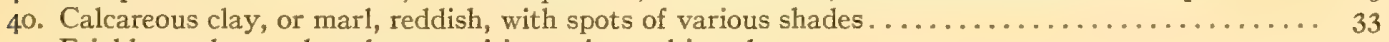

39. Friable sandstone, largely quartzitic, variegated in color . . . . . . . . . . . . . . . . . . r5

38. Conglomerate and arkose grit; most conglomeratic in center; a grit with some pebbles in upper and lower portions; pebbles of greenish slates and schists, quartzite, granite, and greenish porphyry.

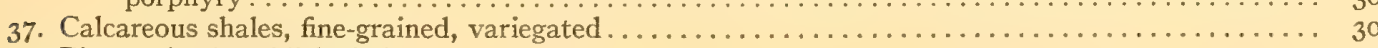

36. Fine-grained, reddish shale . . . . . . . . . . . . . . . . . . . . . . . . . . . .

35. Massive sandstone, coarse-grained, cross-bedded, streaked with light-colored layers; some shaly

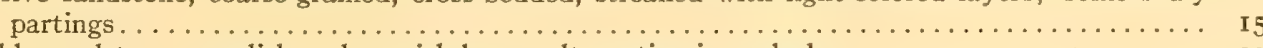

34. Friable sandstone, purplish and grayish layers alternating irregularly . . . . . . . . . . . . . 20

33. Sandstones, finely laminated, compact, cross-bedded, variegated ................... 25

32. Calcareous clay shales, graduating into more massive sandy shales and a rather tough sandstone. Io

31. Sandstone, micaceous, red or green, carrying a thin layer of coarse conglomerate near the top.... Io

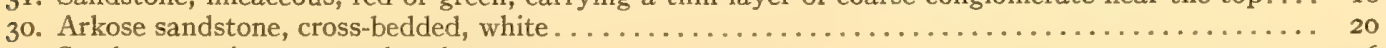

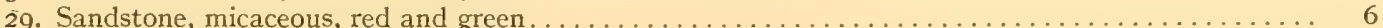

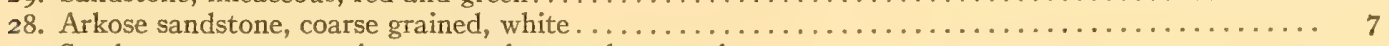

27. Sandstone, compact, micaceous, salmon color to red . . . . . . . . . . . . . . . . . . . . . . . . . .

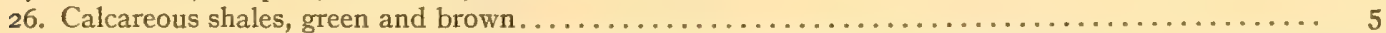

25. Sandstone, micaceous and compact, containing layers of gnarly limestone from 2 to 2 inches thick.

24. Calcareous sandstone, generally red, but mottled; contains thin layers of gnarly limestone..... I5 
23. Arkose sandstone, cross-bedded and conglomeratic in part; this layer is purple at the base, and this color alternates with greenish-yellow and red bands; in the upper part a white and cream

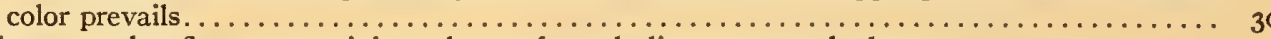

22. Sandstone, rather flaggy, containing a layer of gnarly limestone at the base............. I8

2I. Calcareous sandstone, shaly in the lower part and containing gnarly limestone near the top; color,

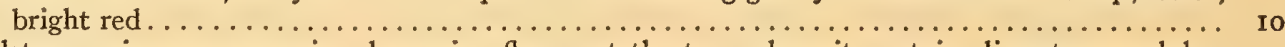

20. Sandstone, micaceous, massive, becoming flaggy at the top, where it contains limestone nodules;

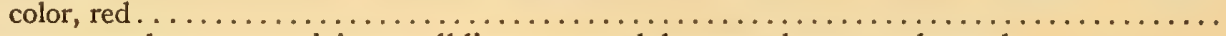

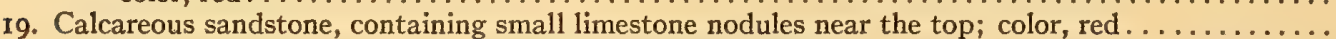

18. Calcareous sandstone and red arkose, containing limestone pebbles; purple and white in the

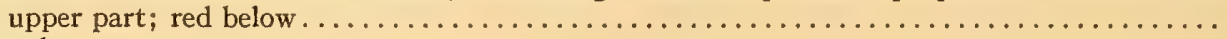

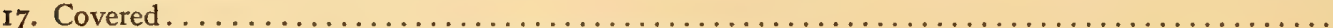

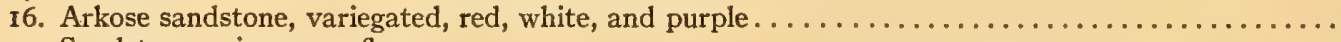

I5. Sandstone, micaceous, flaggy . . . . . . . . . . . . . . . . . . . . . . . . . . .

14. Arkose sandstone, flaggy, becoming finer grained and micaceous in the upper part; color, pink, with

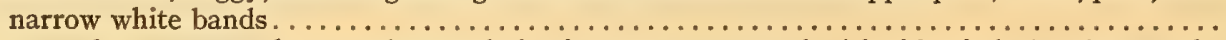

13. Arkose sandstone, somewhat conglomeratic in the upper part, and with thin shaly bands near the center and the top; color, white and pink, irregular bands $\ldots \ldots \ldots \ldots \ldots \ldots \ldots \ldots$

12. Sandstone, micaceous, flaggy, very thin bedded at top; color, red. . . . . . . . . . . . . . . . .

I1. Calcareous sandstone; a few thin layers of nodular limestone; color, red . . . . . . . . . . . . . . .

Io. Sandstone, micaceous, flaggy; color, red . . . . . . . . . . . . . . . . . . . . . . . . . .

9. Sandstone, micaceous, flaggy, becoming more compact in upper part..................

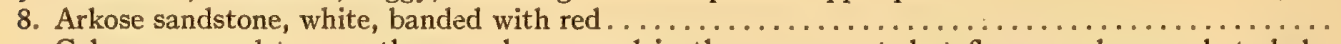

7. Calcareous sandstone, rather poorly exposed in the upper part, but flaggy and somewhat shaly, becoming more shaly in the lower part, and containing nodules of limestone; color, red.....

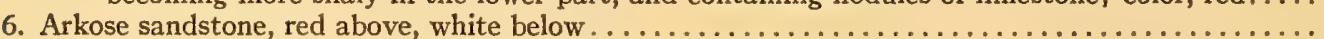

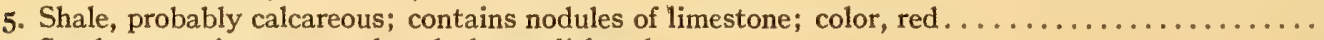

4. Sandstone, micaceous; color, dark purplish red. . . . . . . . . . . . . . . . . . . . . . .

3. Calcareous sandstone, irregularly nodular and flaggy; contains gray nodules of limestone, but no

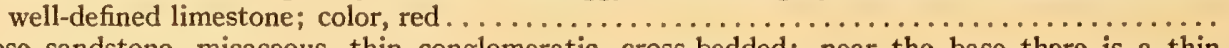

2. Arkose sandstone, micaceous, thin conglomeratic, cross-bedded; near the base there is a thin black shale which is quite variable; color, white, with bluish and green zones......... I5

r. Calcareous sandstone, with a gnarly gray limestone at the top; color, red . . . . . . . . . . . . ro

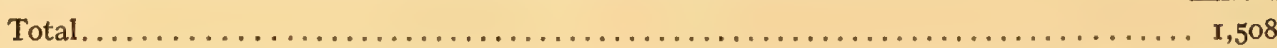

The most complete section of the Cutler occurs in the Dolores Valley, below Rico, Colorado. ${ }^{1}$ There is exposed 98 feet of the formation, the upper 32 to 35 feet are arkosic and the rest shale and sandstone with a subordinate amount of limestone; a section is given on page 48 of the article cited. The space immediately below the Cutler is covered and it is not known whether the Rico is present or not.

The Hermosa is made up of 490 feet of shale, sandstone, limestone, and grit. (Section on page 48 of Cross and Larsen.)

The Molas is at least Ioo feet thick, mostly calcareous shale. There is much of the formation that is "almost a red clay, but where the calcareous element is prominent the mass becomes irregularly nodular or lumpy." Layers or lenses of limestone are rare. This formation is persistent throughout the San Juan region.

In I9I0, Cross and Spencer ${ }^{2}$ first described the Rico formation:

"It is here proposed to apply the name Rico to a formation assumed to be about 300 feet in thickness, occurring between the Hermosa or characteristic Pennsylvanian Carboniferous and strata assigned at present to the Trias of the

${ }^{1}$ Cross, Whitman, and E. S. Larsen, Contributions to the Stratigraphy of Southwestern Colorado, U. S. Geological Survey, Professional Paper No. 90, p. 39, I9r4.

${ }^{2}$ Cross, Whitman, and A. C. Spencer, Geology of the Rico Mountains, Colorado, 2 Ist Annual Report U. S. Geological Survey, part II, p. 59, I900. 
San Juan region-the Dolores formation. It is made up of sandstones and conglomerates with intercalated shales and sandy fossiliferous limestones. In its lithological features it resembles the strata immediately above it, but its fossils are distinctly of Paleozoic age, and while many of its forms are common to the Hermosa formation, others are of Permian type, so that it seems proper to designate its age Permo-Carboniferous, to indicate that it is transitional between these divisions of the Carboniferous system. In the Rico region the formation is conformable upon the Hermosa and is followed by the Dolores with seemingly perfect parallelism of stratification. The fauna as a whole has an aspect quite different from that of the Hermosa, since it is largely composed of lamellibranchs as opposed to the brachiopod assemblage of the lower formation. The boundary between the Rico and Dolores formations is at present entirely artificial, being based upon the highest known occurrence of the Rico fossils. The former is made to include only strata characterized by the Rico fauna, while the latter comprises the apparently unfossiliferous medial portion of the Red Beds, together with the upper part, of known Triassic affinities. The actual age of the unfossiliferous Red Beds is thus left in doubt; they may eventually prove to be either Permo-Carboniferous, true Permian, or Trias. They correspond to [a part of] what has been called Trias throughout the Rocky Mountain province."

In their 1905 paper, Cross and Howe ${ }^{1}$ say of the Rico formation:

"The views expressed in the Rico report on the age and relations of the Rico formation were based mainly on the opinion of G. H. Girty as to the invertebrate fauna. That opinion was more completely stated by Girty in his full discussion of the Carboniferous faunas of Colorado. The more recent work in the San Juan region, and especially in the Animas Valley, has shown that the Rico formation is not a persistent feature of the Red Bed section, nor its fauna so markedly distinguishable from that of the Hermosa beds, as was seemingly the case from observations in the Rico mountains. At even a few miles distance to the east or southeast from that district, the transition from the unfossiliferous Red Beds to the Hermosa is no longer through a marked reddish zone 300 feet in thickness. The Rico fossils are found in certain peculiar limestones, plainly to be correlated with those so marked in the Rico formation, but these fossil-bearing strata are not necessarily intercalated in a red section and are limited to a very narrow band. Moreover, there is mingling of forms supposed originally to be characteristic of the Rico with those of the Hermosa. These observations make the Rico formation a local development, having less importance in the analysis of either the Red Beds or the Carboniferous section than was at first assigned to it."

Cross and Howe, in the paper just cited, make several observations worthy of note on the correlation and interpretation of the red beds of southwestern Colorado.

(Page 466.) "If the Aubrey and Hermosa are practically equivalent, as the stratigraphic relations suggest, the Cutler beds occupy a position corresponding to that of the Permian of the Kanab Valley in Utah and the formation of the Zuñi Plateau referred to the Permian by Dutton ***."

${ }^{1}$ Cross, Whitman, and Ernest Howe, Red Beds of Southwestern Colorado and Their Correlation, Bull. Geol. Soc. Amer., vol. 16, p. 452, 1905. 
(Page 472.) "The general conditions under which correlation of the San Juan formations with those of the Plateau section must be made are as follows. Adjacent to the mountains there is a broad zone of gentle westward slope in which Cretaceous beds occur. The main streams flowing west and south cut valleys into and in some places through the Cretaceous into underlying formations. Nearer the canyon of the Colorado the valleys widen and broad platforms and terraces of Jurassic and Triassic beds appear, the Cretaceous being restricted to the divides and isolated mesas. The Paleozoic formations appear at first only in isolated exposures in the deeper canyons, but far to the southwest rise to form the broad plain called the Colorado Plateau, on the south side of the Grand Canyon. Thus the older the formation the greater are the gaps between districts of good exposures, and the greater the likelihood that in the covered tracts unsuspected complications have entered into the problem."

(Page 473.) [In I899, A. C. Spencer made a trip into the Paradox and Sinbad Valleys, where he found below the Dolores] "coarser Red Beds, often conglomeratic, with pebbles 3 inches or more in diameter, and several hundred feet of such strata were noted. No opportunity was found to measure a section showing the full thickness of these coarser Red Beds, but, as observed by Peale, they are underlain by fossiliferous Pennsylvanian Carboniferous in Sinbad Valley * * *."

Cross and Howe suggest (page 475) that the lower 5I4 feet, red sandstones, of Newberry's generalized section of the valley of the Colorado (Report of Expedition from Santa Fe, New Mexico, to the Junction of the Grand and Green Rivers of the Great Colorado of the West in r859) is equivalent to the Cutler.

(Page 477.) [Dutton referred the lower 450 feet of Newberry's saliferous series to the Permian. This consists of] "sandy shales, containing gypsum and selenite in abundance, with here and there thin bands of limestone.' At some unspecified horizon in this formation Dutton found 'several specimens of Bakewellia and an attenuated form of Myalina.' On this ground he correlates these beds with the Permian of the Kanab Canyon district, where Walcott had discovered a more extensive fauna. 'The Permian beds are distinguished for their dense and highly variegated colors-chocolate, maroon, dark brownish reds alternating with pale, ashy gray, or lavender colors.'

"The Permian strata thus described are overlain by 'a very coarse, almost conglomeratic sandstone,' some 50 feet in thickness, which Dutton correlates unhesitatingly with the 'Shinarump conglomerate' (a particular conglomerate within the Shinarump group), referring to the fact that it is persistent and uniform in aspect wherever it appears through the plateau country of Utah and Arizona."

Cross and Howe suggest (page 478) the equivalency of Dutton's Permian and the Cutler, but note that there is no community of species in the underlying Pennsylvanian Aubrey and Hermosa, thus indicating that though the stratigraphic position is the same, there is no certainty the formations are equivalent.

The deposits of the upper Paleozoic of west-central Colorado are discussed in the chapter upon the Pennsylvanian beds of the basin region. 


\section{E. PERMO-CARBONIFEROUS OF THE NORTHERN PART OF THE BASIN PROVINCE.}

A discussion of the Permo-Carboniferous beds of the Basin Province was given by the author in Publication 207 of the Carnegie Institution. To this are added recorded observations completing the description and showing the relation of the beds of the Basin Province to those of the Plains Province.

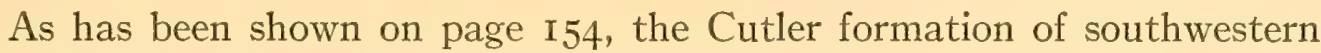
Colorado and adjacent parts of Utah show the last traces of the red beds of the Permo-Carboniferous. North and west of this region the equivalent horizon is either absent or is occupied by different deposits.

The Weber sandstone horizon, traced on pages $120-136$, becomes of importance about where the Red Beds of Permo-Carboniferous age disappear. It is very possible that it is represented by the Lower Aubrey sandstone of the Grand Canyon section, but it becomes more prominent and definite in Central and Northern Utah and breaks up in southern Montana. Using this well-determined horizon as a guide marking the upper Pennsylvanian, the layers above it are mostly regarded as Permian, or Permo-Carboniferous.

The condition of the upper beds in the Wasatch and Uintah Mountains is as follows:

King's description of the upper part of the Weber Canyon section is quoted in Professional Paper No. 7 I of the United States Geological Survey, page 377 :

"Conformably overlying the [Weber] quartzite is a very heavy bed of much altered gray limestone from 600 to 700 feet thick. The bedding planes are often entirely obliterated and the material extremely crystalline, showing traces of great interior disturbance. The lower beds show a true conformity with the underlying quartzite. $* * *$ The average colors of these limestones are creamgrays, inclining often to white in the more crystalline portions. $* * *$ Overlying this main body of 700 feet of limestone is a series of yellow shaly limestones I75 feet thick. $* * *$ Overlying these calcareous shales, as heretofore quite conformable, is a series of sand and mud rocks, all more or less calcareous, varying in color from chocolate to olive, with red argillaceous sandstones, the whole about 225 feet thick. It has the appearance of a comparatively shallow water deposit, made of argillaceous material, limestone, and sand, the thickness of the individual beds being unusually limited. There are very many beds not over an inch thick. On the upper surface of the strata, at several horizons, ripplemarks are preserved with unusual distinctness and on a scale of fineness not often seen, the distance between the wave and the trough being frequently not over an inch or an inch and a half. Alternating dark chocolate and olive-colored shales form the lower 200 feet of this group, while the upper 25 or 30 feet are pretty solid sandstone. Over these, still conformable, are Ioo feet of yellow and olive calcareous shales, which are so earthy as usually to decompose, yielding a bad outcrop. Above this is a bed of bluish-gray limestone, rather compact, about I50 feet in thickness. Next comes 20 feet of reddish-brown clayey sand, hardly compacted into rock, 
containing thin stony seams intercalated at intervals in the soft, easily eroded matter. This is immediately followed by 75 feet of a yellowish-gray, brittle, easily decomposed limestone. Next above are roo feet of light-colored, very thinly bedded limestones, that give way to 100 feet more of dark, siliceous, tough limestone, which breaks under the hammer with great difficulty, yielding an exceedingly rough, ragged fracture."

Blackwelder ${ }^{1}$ regards the alternating series of dark limestone and shale with local sandstone beds, which rest upon the Weber quartzite as corresponding to Boutwell's Park City formation. "There is considerable although not conclusive evidence of an important unconformity between the Weber and the Park City formations." 2

In the Uintah Mountains, as described by Weeks, ${ }^{3}$ there are 600 feet of Permo-Carboniferous red and purple shales and blue limestone on the east side of the Duchesne River below the mouth of the West Fork, followed by "I,000 feet of light gray and white sandstones, with some interbedded limestones in the lower part. In the upper part these sandstones occur in alternating layers of soft and compact beds full of peculiar black points and specks. These are succeeded by 800 to 900 feet of red shales, with a prominent band of light-colored shale at the top."

In northeastern Utah, southeastern Idaho, and southwestern Wyoming the various limestones and shales of the Wasatch and Uintah Mountains give place to the phosphate-bearing Park City formation of Boutwell, originally described and named in 1907.4 It was more fully discussed in I9I2. The later description is quoted in part below:

"This formation is made up largely of calcareous members, but it also embraces several sandstones and quartzites. *** In general the formation comprises a thick limestone in its lower part, several minor limestones in its upper part, and a number of thin calcareous beds near the base, with intercalated quartzites and sandstones."

The type section of the formation is exposed in the Big Cottonwood Canyon:

Grayish-white limestone, with fine gray and white cherts increasing toward bottom......... 19

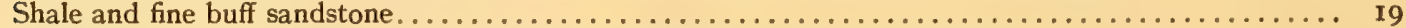

Dark-gray limestone; thin chert, red shale, and porous loose members at base............. 7

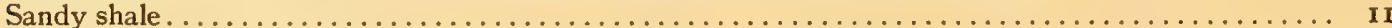

Yellowish-gray quartzitic sandstone changing into cherty white lime below............. 2 I

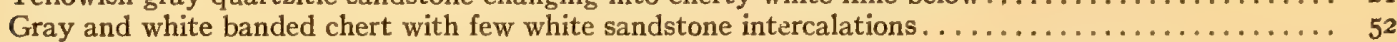
Fine calcareous sandstone, with lentils of chert and brecciated fragments of sandstone........... 8

${ }^{1}$ Blackwelder, Eliot, New Light on the Geology of the Wasatch Mountains, Utah, Bull. Geol. Soc. Amer., vol. 21 , p. 517, I910.

${ }^{2}$ Willis, Bailey, Index to the Stratigraphy of North America, U. S. Geological Survey, Professional Paper No. 7I, p. 379, I9I2 (citing Blackwelder).

${ }^{3}$ Weeks, F. B., Stratigraphy and Structure of the Uintah Range, Bull. Geol. Soc. Amer., vol. I8, p. $439,1907$.

${ }^{4}$ Boutwell, J. M., Stratigraphy and Structure of the Park City Mining District, Utah, Jour. Geol., vol. I 5, p. 439, I907.

5 Boutwell, J. M., Geology and Ore Deposits of the Park City District, Utah, U. S. Geological Survey, Professional Paper No. 77, p. 49, 1912. 
Float of buff sandstone and shale, becoming more shaly and calcareous at base............ I04 Siliceous arkose comprising mainly rounded quartz grains and feldspars cemented with ferruginous

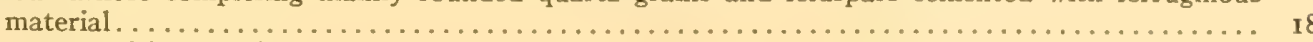

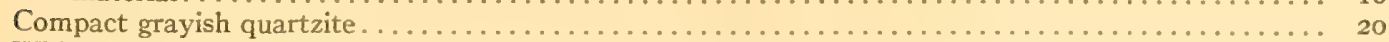

White compact sugary sandstone fossiliferous at base . . . . . . . . . . . 8

Fine gray and pink massive quartzite with brown sandstone and gray-white chert bands near base... 30

Light-gray limestone weathering whitish gray with an imbricated pattern; fine gray lime near base carries good faunas at two horizons in particular, 20 and 55 feet above the base ......... 27

Gray calcareous sandstone . . . . . . . . . . . . . . . . . . . . . . . . . . . . . 24

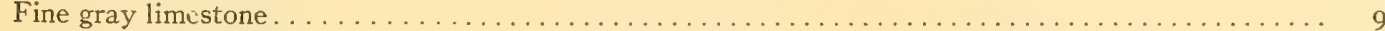

Float showing bits of grayish and brown calcareous sandstone $\ldots \ldots \ldots \ldots \ldots \ldots \ldots \ldots \ldots \ldots \ldots \ldots \ldots$

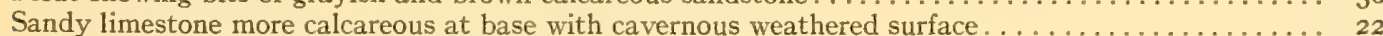

Float; upper sandy beds at top of Weber quartzite . . . . . . . .

"Deposition.-The conditions which prevailed during the deposition of this formation, a few hundred feet in thickness, marked the transition from those under which the great thickness of sandstone had been laid down to those which followed, when the sediments formed red shale. The composition of the limestones, sandstones, and shale points to their deposition in comparatively shallow water and the limestones contain shallow-water remains. The repeated alternation of these lithologic types shows unsettled conditions either as regards elevation or deposition along shore, and it is probable that both occurred.

"Age and stratigraphic relations.- The fauna of the Park City formation, which is better known from areas in Idaho, Wyoming, and other parts of Utah than from the Park City district itself, may be properly limited to two faciesone which is best known in the dark phosphatic and calcareous shales around Montpelier, Idaho, and one which occurs in the limestones that at some points overlie these shales and at others seem largely to replace them. The fauna of the phosphate shales and limestones has been described in United States Geological Survey Bulletin 436. The fauna of the limestones is characterized by the remarkable species Spiriferina pulchra, with which are associated types of Productus, Bryozoa, etc. Both faunas are suggested by the collections from the Park City district, the one by more or less abundant Lingulidiscina utahensis, the other by spiriferinas, probably referable to $S$. pulchra. The age of these faunas is now provisionally determined as Permian.

"No unconformity was observed with the underlying Weber quartzite or the overlying shale or within the formation. Accordingly it would seem that sedimentation proceeded unbroken from Mississippian time through that part of the Pennsylvanian which is represented by the Park City formation."

"The conditions which prevailed during the closing part of Permian time, as shown by the alternating limestone, sandstone, and shale of the Park City formation, were at different stages those of sea bottom, shallow shore bottom, and exposed shore with mud flats." 1

The Permo-Carboniferous age of the Woodside member of the Park City formation was demonstrated by Girty, ${ }^{2}$ who writes:

"The three members of the Park City formation vary from point to point in lithology and in thickness, as well as in fauna. In the Montpelier district the upper limestone marks an important horizon for determining the position of the phosphate deposits. It is massive, contains here and there much black chert,

${ }^{1}$ Boutwell, J. M., U. S. Geological Survey, Professional Paper No. 77. p. I04.

${ }^{2}$ Girty, G. H., The Fauna of the Phosphate Beds of the Park City Formation in Idaho, Wyoming, and Utah, U. S. Geological Survey Bull. 436, p. 6, I9Io. 
and is at many places full of fossils, especially of several species of Productus, from which fact it is of ten called the 'Productus limestone.' Not far to the north, in the Swan Lake district, the upper limestone is replaced by siliceous or cherty shale of dark-purplish color. This cherty shale is not as a rule a prominent feature of the stratigraphy nor does it at many places contain fossils.

"The lower limestone in the Montpelier region is of a whitish or buff color and at some places appears to be a fine-grained calcareous sandstone rather than a limestone. As a rule its fossils are very few and so ill preserved as to be indeterminable. In the Swan Lake district, on the other hand, this bed is a massive whitish, more or less siliceous limestone containing in abundance poorly preserved silicified fossils, among them species of Spirifer, Squamularia, and probably Composita. In its upper portion a large semireticulate Productus is found, and fine, black, earthy limestones that locally appear at its very top contain numerous specimens of Spirifer, Productus, and Composita. In this region the lower limestone serves much better than the upper as a guide for finding the phosphate beds, and for several reasons, more or less obvious, it seems to have been generally inferred that the guide rock was the same in both areas and that the series was overturned in the Swan Lake region. There is, however, hardly room for reasonable doubt that the stratigraphic sequence is normal in both regions and that the beds themselves differ in character in the two areas.

"The phosphate beds consist mostly of soft rock, shales, phosphates, and impure limestones, the latter seldom more than a few inches thick. The shales are more or less phosphatic and the phosphate bands are more or less argillaceous. Their prevailing color is black, weathering to brown, but in the Beckwith Hills the color of the phosphate and associated rock is buff or even reddish. The thickness of the phosphate-bearing shales ranges from 60 to roo feet. The main deposits of phosphate occur, as a rule, at the base of the series, so that in the Montpelier district they lie about that distance below the 'upper Productus limestone,' but in the Swan Lake district they occur immediately above the 'lower Productus limestone.'

"The remaining formations concern the present report less closely. The beds below the Park City formation in southern Idaho have been identified with the Weber quartzite, which holds a similar position in the Wasatch Range. The equivalence of the strata in the two sections, especially in detail, is not entirely clear. In Idaho the 'lower Productus limestone' abruptly grades below into white sandstones and quartzites, and the Mississippian limestones are succeeded above by light-colored limestones that include more or less interbedded quartzitic sandstones, these being probably of Pennsylvanian age. Between these two quartzite-bearing groups comes in a series of soft beds approximately $\mathrm{I}, 000$ feet thick. They are poorly exposed, but seem to comprise soft sandstones and soft earthy limestones of reddish or yellowish tints. If the upper quartzitic beds are called the Weber, the division between the Weber and the Park City is not easy to determine. It may prove desirable to draw the line at the base of the phosphate shales and to include the siliceous limestones and calcareous sandstones of the 'lower Productus limestone' in the Weber. If so, the thin stratum of black limestone which at some places occurs at the base of the phosphate beds and has here been spoken of as part of the 'lower Productus limestone' may perhaps better be united with the Park City formation, because the fossils obtained in it indicate a certain change from the fauna of the white limestone below and an affinity with the fauna of the phosphate series above. In any event, the Weber 
quartzite, whose fauna is almost unknown, seems to show considerable modification in the Idaho sections.

"In notable contrast to the Weber formation, the beds above the Park City formation show striking persistence in their main lithologic and paleontologic characters. These are the 'Permo-Carboniferous' beds of the King Survey and were divided by Boutwell in the Park City district into the Woodside, Thaynes, and Ankareh formations. It seems all but certain that the 'Permian' of Walcott's section in Kanab Canyon, in southern Utah; the 'Permo-Carboniferous' of the Wasatch Mountains, in northern Utah; and, in part, the 'lower 'Triassic' of southeastern Idaho are one and the same series. The Woodside, Thaynes, and Ankareh do not, perhaps, maintain precise boundaries throughout all this territory, and in Idaho the first occurrence of Triassic ammonites (Meekoceras beds) is conventionally taken as the base of the Thaynes. ***"

"The Triassic age of at least the major portion of the 'Permo-Carboniferous' (Thaynes and Ankareh) seems to be shown by fairly satisfactory evidence-the presence of an extensive ammonite fauna of Triassic type and the practical absence of any distinctive Carboniferous forms. In advance of a detailed study of these faunas, however, it may be pointed out that above the Meekoceras beds there are zones which contain great numbers of Rhynchonella closely related to the Carboniferous Pugnax utah and many specimens of apparently true Myalina, not unlike Carboniferous species.

"It is much less certain that the Woodside formation is not Paleozoic (Permian?). A preliminary study of the fauna of the Woodside shows that, except that it has yielded no ammonitic forms, it does not differ materially from the fauna of the Thaynes and presents a strong contrast to the Carboniferous fauna of the Park City. Lithologically also there is a well-marked division between the Woodside and the Park City formation, and no lithologic boundary can be traced between the Woodside and the Thaynes. That the Woodside, Thaynes, and Ankareh form a natural group is indicated by the classification of these rocks adopted by most geologists. If the Thaynes is Mesozoic, the obvious line between the Mesozoic and the Paleozoic would seem to be the line between the Park City and the Woodside. If, then, as may be tentatively concluded, the Woodside does not represent the Permian, the natural question to follow is, Does not the Park City formation belong in the Permian? A decisive judgment on this point should wait upon a careful study of the faunas obtained from other members of the Park City beds, as well as upon a study of other related faunas less certainly appearing at the same horizon. Because of the close relationship or identity of many species of these faunas with the Gschelian fauna of Russia, I am provisionally holding that the Park City formation is older than the Permian.

"Anyone at all familiar with the Carboniferous faunas of the Mississippi Valley will at once recognize the fact that the forms found in the phosphate beds, individually as well as collectively, are quite different from any others found in that area. In fact, but few of the phosphate species have closely related forms in the Pennsylvanian, and a correlation by paleontology with any definite portion of the Pennsylvanian section is at present impossible. Even among western faunas this has an extremely individual and novel facies, one which is known to me as occurring only in a well-defined area.

"Though the phosphate fauna possesses a remarkable individuality of facies, it is not altogether out of relationship with other formational faunas, for with the aid of the fossils from the associated rocks it can be recognized as belonging 
to a fauna widely dispersed over the West and traceable, it is believed, even into Alaska, Asia, and eastern Europe. The other western faunas of about the same geologic age are largely composed of representatives of the Brachiopoda and Byrozoa, especially of the Productidæ and Spiriferidæ. Thus there is little common ground for comparison, but though the abundant and characteristic features of the phosphate fauna are peculiar to it, where a common ground for comparison does exist an agreement can be found to a considerable extent, and some of the less abundant forms have a wider distribution. These western faunas have not been studied in detail and in many localities the rocks in which they occur have not been discriminated into formations and named, so that it is possible to speak of them only in a general way. If, however, we eliminate the beds of recognized lower Carboniferous age, such as the 'Wasatch limestone' of Utah (lower part), the Redwall limestone of the Grand Canyon section, and the Baird shale of California, and also certain younger divisions such as the 'PermoCarboniferous' of the Wasatch Mountains and surrounding region, the Permian of the Grand Canyon section, the Guadalupian series of Texas, and, perhaps, a few others, we have left a group of rocks, as already remarked, which is widely distributed throughout the West (including Alaska) and which constitutes the major portion of the Carboniferous representation in that extensive area. The fauna of these formations thus tentatively grouped together, though presenting many local modifications, can, in a general way, be correlated with the Gschelian fauna of the Ural Mountains, some of the American assemblages presenting truly remarkable resemblances to those of Russia."

The Park City formation, which Schultz ${ }^{1}$ regards as equal to the Phosphoria formation and the upper part of the Wells formation in eastern Idaho, is exposed on both the northern and southern sides of the eastern and western ends of the Uinta Mountains. A geologic map showing the exact location of the outcrops is given in his publication. His description of the Park City formation is as follows: ${ }^{2}$

"Park City Formation (Pennsylvanian and Permian).

"The Weber quartzite is overlain by a series of limestones of Pennsylvanian and Permian age, with which are associated some calcareous sandstones, shales, and chert. This formation contains the phosphate deposits and has yielded the bonanzas that during the last decade have made the Park City mining district, in the Wasatch Range, Utah, a famous lead and silver camp. The formation consists for the most part of thin-bedded arenaceous limestones and shales, with some massive limestone ledges near the base. Although consisting chiefly of limestones, it may be subdivided into four more or less distinct members which are usually recognizable in different parts of the field: (I) the upper thin-bedded shaly gray limestone series, which weathers readily, forming depressions, and at a distance has the appearance of a clay or shale bank; (2) the upper or cherty limestone beds, which contain a large percentage of concretionary chert nodules and lenses; (3) a phosphatic shales series, in which bands of chert and limestone occur; and (4) the lower limestone member, consisting primarily of massive light

${ }^{1}$ Schultz, A. R., A Geologic Reconnaissance of the Uinta Mountains, Northern Utah, U. S. Geological Survey Bull. 690-C, p. 76, 1918.

2 Loc. cit., p. 46. 
and gray limestones, some beds of which are from 5 to 25 feet thick. The upper member of shaly limestones has thus far not furnished any identifiable fossils, but nevertheless has lithological characteristics so distinctive that it is easily recognized wherever it is exposed. On Brush and Little Brush Creeks and in the vicinity of Green River on both sides of the range this member is considerably thicker than at the west end of the field and consists of grayish-drab limestone and shaly limestone with a few streaks of pink or red clay near the top, all weathering to a dull slate gray, so that the entire series, seen from a distance, looks like a gray clay bank. In some respects these beds resemble the Dinwoody formation along the east side of the Wind River Mountains, in western Wyoming. Future detailed work may result in differentiating them into a formation, but for the present they are retained as a part of the Park City formation.

"The upper cherty limestone member is variable in detail, but is prominent and easily recognized throughout the range. It consists of massive gray to cream-colored limestone 20 to 25 feet thick (underlain by gray and greenish dark chert in a matrix of shale). It is a controlling factor in the topography and produces long faceted dipslopes along the south side and a part of the north side of the mountain front. Certain parts of this member are highly fossiliferous and contain abundant specimens of Leioclema, Derbya, Spiriferina pulchra, and Lingulidiscina utahensis, other parts tesemble somewhat the Rex chert member of the Phosphoria formation of eastern Idaho.

"The phosphatic shale is probably the most distinctive member of the Park City formation. It is made up largely of black and green, decidedly fissile shale 40 to 50 feet thick and beds of limestone, sandstone, chert, and phosphate ranging in thickness from a few inches to several feet. Some of the beds of limestone and phosphate contain an abundance of fossils, a few of which have been collected for identification. In addition to the Bryozoa there are numerous comminuted fossil fragments, glauconite, and scattered foraminiferal shells. This member is probably equivalent to the lower part of the Phosphoria formation in eastern Idaho, as described by Richards and Mansfield. ${ }^{1}$

"The lowest member consists chiefly of massive limestone with some beds of shale and sandstone. It is more variable than the overlying members and in some localities appears to be entirely missing, as the phosphate shale or phosphate bed rests directly upon the Weber quartzite. It is probably owing to variations in this member and the upper member of the formation that the Park City shows so great differences in thickness throughout the field. The total thickness ranges from 250 feet or less to 850 feet or more in parts of the field where the beds have been measured. In certain portions of eastern Idaho where the phosphate deposits have been studied in great detail the lowest member of the Park City formation as here described was considered a separate member of the Park City formation and later was included with the Weber quartzite and underlying beds as a part of the Wells formation. It appears, however, from the facts thus far gathered in the Uinta range, that it must be considered as a part of the Park City formation as defined by Boutwell in his Park City reports.

"The contact between the Weber quartzite and the overlying Park City formation has been a subject of considerable study without definite results. The beds in many localities appear to be conformable, but the relations from place to place and the position of the phosphate series with regard to the Weber

${ }^{1}$ Richards, R. W., and G. R. Mansfield, Geology of the Phosphate Deposits Northeast of Georgetown, Idaho, U. S. Geological Survey Bull. 577, I9I4. 
quartzite make it appear that the Park City formation unconformably overlies the Weber quartzite. However, until the beds are studied in greater detail and careful areal mapping is completed it will not be possible to state definitely the extent or magnitude of the unconformity. It seems improbable, however, that the relation between the Weber quartzite and the phosphate beds of the Park City formation can be satisfactorily accounted for in any other manner. Boutwell, who studied the formation in the Park City region of Utah, comes to the conclusion that the strata lie conformably upon the underlying Weber quartzite and that sedimentation proceeded unbroken from Mississippian time to the end of Park City time. He calls attention, however, to the fact that one geologist reported a marked unconformity at this horizon and that his own studies were not as conclusive or definite as might be wished. Blackwelder, ${ }^{1}$ in his studies of the Wasatch Range, recognized the unconformable relation between the Weber quartzite and the overlying Park City beds and concluded that in the Wasatch Range there is an unconformity between the Weber quartzite and the overlying Park City phosphatic beds of Permian age. In another report Blackwelder ${ }^{2}$ states that the base of the Park City formation is generally marked by beds of white and pink soft sandstone separated from the Weber quartzite by an obscure unconformity, which appears nevertheless to be one of considerable magnitude. Similarly in the Wind River and Gros Ventre Mountains the Park City is known to rest upon the Tensleep sandstone (horizon of Weber quartzite), in apparent conformity at many localities, but close examination reveals evidence of an uneven erosion surface at the base of the Park City beds. A similar unconformity has also been reported by Richards and Mansfield in eastern Idaho. ${ }^{2}$ The conditions that prevailed during the period of deposition of the Park City formation marks the transition from those under which the great thickness of Weber sandstones was laid down to those under which the sediments formed red shale. The strata indicate deposition in comparatively shallow water and show an unstable or fluctuating shore-line, as it appears that both elevation and depression of the shore occurred.

"The irregularities and differences in thickness of the Park City formation may best be illustrated by giving some of the measured sections in different parts of the field. Boutwell's type section of the Park City formation is Big Cottonwood Canyon, Utah, given below (see page 160 of this work), does not state the thickness of the phosphate bed or the phosphatic shale, nor does he show the horizon at which it occurs. However, the work done by Gale in the Park City district in 1909 proves that the phosphate occurs near the middle of the formation and is included with the 104 feet of beds overlying the I 8 feet of siliceous arkose. In discussing the phosphate deposits Boutwell states that the phosphate bed noted at several points is about 3 feet thick and contains 32.6 per cent $\mathrm{P}_{2} \mathrm{O}_{5}$, or 7 I per cent bone phosphate."

Schultz gives several sections other than the type section of Boutwell cited above. In commenting on the phosphate rock, he describes its oolitic character and notes the irregularity of the layers:

${ }^{1}$ Blackwelder, Eliot, New Light on the Geology of the Wasatch Mountains, Utah, Bull. Geol. Soc. Amer., vol. 21, pp. 531-533, 542, I9Io.

${ }^{2}$ Blackwelder, Eliot, Phosphate Deposits East of Ogden, Utah. U. S. Geological Survey, Bull. 430, pp. 536-55r, 1910.

Richards, R. W., and G. R. Mansfield, loc. cit., pp. 16, 22, 
"When compared over large areas these layers are found to be variable as to both character of the bed and quantity of phosphoric acid present, not only vertically but horizontally, and yet in many respects they are rather uniform and constant in character and have throughout the field certain common characters."

The Park City formation extends nearly as far north as the Weber and Quadrant quartzites.

Veatch ${ }^{1}$ described briefly the occurrence in southwestern Wyoming. Here the formation occurs in the Tunp Range, about 15 miles west of Kemmerer. It is "a series of very arenaceous thin-bedded limestones which, from its stratigraphic position, approximately represents the Upper Coal Measures limestone of the Fortieth Parallel Survey." It is very probable that the same formation occurs in the Crawford Mountains, which extend to the southwest into the type area of the Park City formation or very near to it.

In eastern Wyoming the Park City horizon is represented by the Embar limestone; the equivalence of these beds seems to be more and more definitely established as work in the region progresses.

Woodruff, ${ }^{2}$ in describing the Lander region, says that the Embar formation occurs in the Wind River Mountains adjacent to the Lander oil field. "About half of the Embar formation consists of limestone, most of it massive and crystalline, but certain members of this half are shaly and cherty; the other half of the formation is shale."

The upper member, as given in the section below, is evidently above the Park City formation and is Triassic. The lower part may be called Permo-Carboniferous.

Limestone, shaly and tan-colored; sandy at top; lies immediately below the red shales at the base Feet.

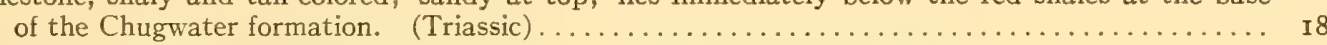

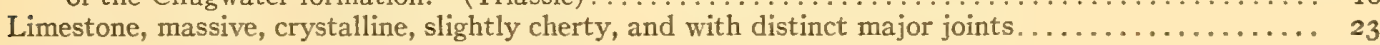

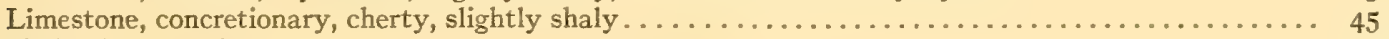

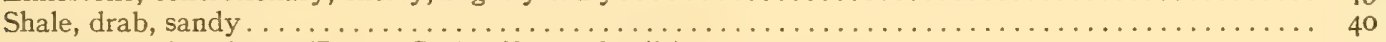
Sandstone, bituminous (Permo-Carboniferous fossils) . . . . . . . . . . . . . . . . . . . . 5

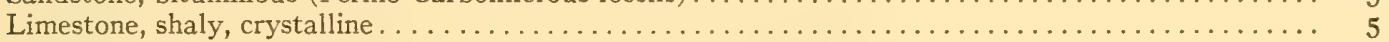

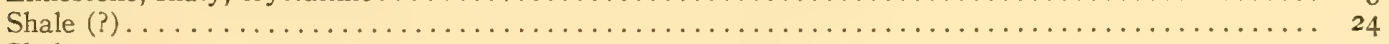

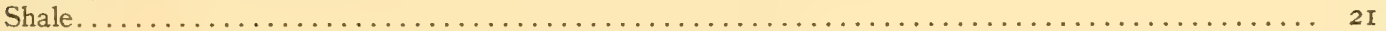

Limestone, massive, impure, with well-developed major joints. . . . . . . . . . . . . . . . . 73

Limestone; contains occasional thin, shaly limestone layers . . . . . . . . . . . . . . . . . . . 90

Darton $^{3}$ in his description of the Big Horn Mountains speaks as follows of the Tensleep and Embar:

(Page 34.) "Tensleep Sandstone.-Its thickness varies from 50 to Ioo feet in the northeastern portion of the region to over 200 feet in the east-central portion and from 250 to 300 feet to the south and west. ***

${ }^{1}$ Veatch, A. C., Geography and Geology of a Portion of Southwestern Wyoming, U. S. Geological Survey, Professional Paper No. 56, p. 50, 1907.

${ }^{2}$ Woodruff, E. G., and C. H. Wegemann, Lander and Salt Creek Oil Fields, Wyoming, U. S. Geological Survey Bull. 452 , p. I2, I9I I.

${ }^{3}$ Darton, N. H., Geology of the Big Horn Mountains, U. S. Geological Survey, Professional Paper No. 5I, I906. 
"The predominant rock is white to buff sandstone in thick massive beds, cross-bedded and of ten weathering into irregular pinnacled forms. *** On the west side of the range, in the vicinity of Paintrock and Tensleep creeks, the formation varies in thickness from 75 to $\mathrm{I} 5 \mathrm{O}$ feet, and in its thicker portions its lower part includes some softer, fine-grained sandstones and the upper member is strongly cross-bedded. $* * *$ The upper portion of the Tensleep sandstone of ten is calcareous and at many points there are one or two beds of a mixture of sand and lime sediments."

The Tensleep sandstone is said in this paper to represent the upper portion of the Minnelusa of the Black Hills.

(Page 35.) "The Embar Formation.-In the southern part of the Bighorn uplift between the red beds and Tensleep sandstone is a limestone with some associated shaly and cherty beds, which, with gradual increase in thickness, is continued westward in the Bridger Range and Owl Creek Mountains. Apparently it is neither a development of the basal portion of the Red Beds nor of the calcareous sandstone which sometimes occurs at the top of the Tensleep sandstone in the region north. *** On the east side of the Bighorn Mountains the formation first appears near the West Fork of Powder River, and, on the west side, in the slopes south of Redbank. It finally attains a thickness of about 200 feet on the ridge south of Thermopolis, where it constitutes an extensive dip slope several miles wide, extending along the north slope of the Bridger Range. Prominent exposures appear in the upper canyon of the Bighorn River, which cuts deeply into this slope. Here the formation consists of 50 feet of massive limestone, underlain by calcareous shale filled with nodules and lenses of chert, a member which merges down into sandy shales and impure limestones. At the base there is a thin mass of sandstone breccia lying on the massive Tensleep sandstone. Owing to extensive faulting, the formation appears only at one point on the south side of the Bridger Range, but it outcrops prominently at the southwestern termination of the Bighorn uplift, 3 miles east of Deranch. Here the limestone constitutes a line of low hogback ridges, at the base of which appear sandy and cherty shales of buff color lying on the Tensleep sandstone. A thick mass of the limestone appears in the 7,000-foot knob 6 miles northeast of Deranch, which at first sight might be mistaken for Madison limestone. Two miles south of No Wood, at the northern end of a short, deep gorge of No Wood Creek, a partial section is exposed in which the Embar limestone is seen to be ro feet thick, somewhat cherty, and lying on Io feet of cherty shales, which extend to the top of the Tensleep sandstone. The limestone is overlain by a yellowish sandy bed, which may constitute the base of the Red Beds. At the head of West Kirby Creek the limestone is underlain by gray and reddish sands, in all about 30 feet thick. A short distance north of No Wood post-office the following section is presented:

\section{Section on No Wood Creek I mile northeast of No Wood, Wyoming.}

Red beds, with ro-foot bed of limestone Ioo feet from base (Chugwater).

Limestone, light yellow, weathers in thin beds, has a layer of flint near the center, and occasional

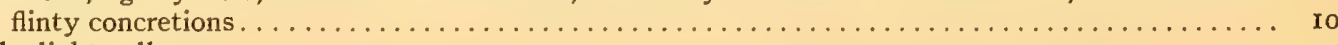

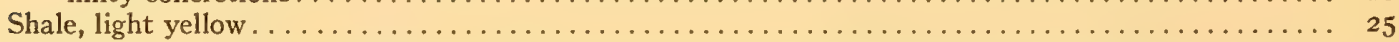
Limestone, massive, of light-gray color, with chert concretions and layers of black chert between

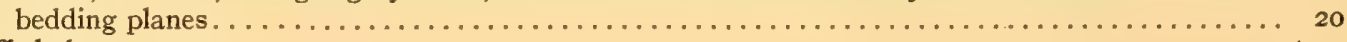

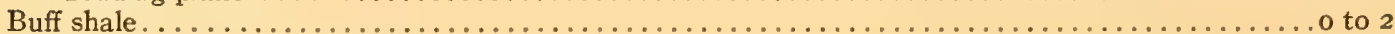
Soft white sandstone (Tensleep). 
"A mile north of this locality there is a similar section, but the basal limestone is thinner, not over Io feet thick, is yellowish in color in its lower portion, and lies directly on the Tensleep sandstone. At the western entrance of the deep canyon, 4 miles north of No Wood, the top limestone underlying the Red Beds is 12 feet thick, massive, cherty, impure, and of yellow color. Next below are 40 feet of shales and soft sandstones, partly pale red, but yellowish near the top. They contain a few layers of limestone and lie on the Tensleep sandstone. On the east slope of Bighorn Mountains the formation appears at intervals in the valley of Buffalo Creek, near the Hole-in-the-wall. The limestone is 20 feet thick, with a 2 -foot massive layer at the top, and with thinner-bedded slabby limestones of greenish-gray color and green shale below, lying on the Tensleep sandstone. The formation is traceable continuously northward to the Red Fork of Powder River, but gradually thins in that direction. On the anticline in Red Fork Valley, 5 miles northeast of Barnum, the Tensleep sandstone is overlain by a thin mass of limestone breccia, merging up into 6 feet of buff sands and greenish shale, which probably represent the northeasternmost extension of the Embar formation."

Blackwelder, ${ }^{1}$ as already indicated, has suggested the equivalence of certain beds in eastern and western Wyoming. The Tensleep of the Bighorns is the same as the Weber of Utah and the southwest; the Embar is the equivalent of the Park City; the Morgan formation of Utah is the equivalent of the Amsden of the Bighorns. In the Gros Ventre Range the phosphate beds become cherty and unfossiliferous. Toward the Wind River Range, Shoshone, and Owl Creek Mountains the phosphate thins and deteriorates and beds exceeding a few inches in thickness do not occur north of the Owl Creeks, northeast of the north part of the Bighorns northeast of the low ranges between Casper and Lander.

Condit, in a recent paper, ${ }^{2}$ gives a description of the Phosphoria formation in Wyoming and Montana, with a map showing the distribution of the Phosphoria and Embar formations and a series of stratigraphic sections. He says (page II3):

"The Quadrant proper is overlain by Ioo to 250 feet of dark-gray cherty quartzite, layers and ropy masses of nodular chert and shale. The sequence is, regarded as equivalent to part of the Park City formation of Utah and Wyoming, but more nearly equivalent to the Phosphoria formation of Idaho, as was recognized in I9I 3 by Richards and later by Stone and Bonine. ***"

"The uppermost beds of the Phosphoria contain poorly preserved brachiopod shells and fish bones, probably of Permian age."

${ }^{1}$ Blackwelder, Eliot, A Reconnaissance of the Phosphate Deposits of Western Wyoming, U. S. Geological Survey Bull. No. 470, p. 458, I9Io.

${ }^{2}$ Condit, D.D., Relations of the Late Paleozoic and Early Mesozoic Formations of Southwestern Montana and Adjacent Parts of Wyoming, Professional Paper No. I20-F, U. S. Geological Survey, I918. 



\section{CHAPTER V.}

\section{THE LATE PALEOZOIC OF BRITISH COLUMBIA.}

It is impossible to identify deposits of Permo-Carboniferous age in either the Basin or the Plains Province farther north than has been indicated in the preceding summary descriptions. It is altogether probable that the uplift which occurred in western British Columbia and in Alaska prevented the northern extension of both the basins of deposition; if any deposits were laid down beyond the limits to which they have been traced they have either been removed by erosion or are buried beneath later deposits, in such large measure that no trace of them has yet been discovered. It is certain, however, that the uplift in the latter part of the Paleozoic terminated marine deposition in northwest North America and formed a surface which must be considered as no small factor in the environment of the life of the time. The exact age of the development of the land conditions is uncertain and the subsequent profound orogenic movements, resulting in metamorphic and volcanic action, were so vigorous as to mask much of the record and make the interpretation exceedingly difficult.

The following descriptions of the beds in British Columbia and in Alaska must serve in part as an illustration of what may be accomplished when more exact knowledge of the age of the rocks and their original condition and extent has been gained.

On the southern part of Vancouver Island, Duncan map area, ${ }^{1}$ there are two series of volcanic and metamorphosed sediments which are provisionally referred to the Carboniferous:

Malahat volcanics: Massive and schistose meta-dacites and meta-andesites, tuffs, and fine-grained cherty rocks.

Leech River formation: Slates, slaty and quartzose schists, micaceous quartzites, amphibolites, and chloritic schists. If this series is to be correlated with the northern deposits at all it is with the lower half of the Ketchikan, etc., below the prevailing massive limestone.

In I912 appeared Daly's report on the Geology of the Rocky Mountain Cordillera at the Forty-ninth Parallel, Memoir 38 of the Canadian Geological Survey. The detailed account of the geology permits an attempt to correlate the Upper Carboniferous and Permian (?) rocks at this latitude.

${ }^{1}$ Clapp, C. H., and H. C. Cooke, Geology of a Portion of the Duncan Map-area, Vancouver Island, British Columbia, Summary Report, Canadian Geological Survey, for I9I3, p. 89 , I9I4. 
In the Skagit Mountain range the following series has been made out (page 546):

Unconformity.

Upper Carboniferous................ \{ Vedder greenstone (altered gabbroid rock).

Upper Carboniferous (and older) ....... $\left\{\begin{array}{l}\text { Chilliwack series. } \\ \text { Hozomeen series. }\end{array}\right.$

The oldest, the Hozomeen series, covers 3 or more square miles north of Glacier Peak and just east of the main divide of the Skagit Range. The prevailing rock is a cherty quartzite, occurring in thin, flaggy beds, from I inch or less to 3 inches in thickness. Occasional bands of probably contemporaneous and extrusive greenstone occur, but there is no limestone in the main area.

The Chilliwack is exposed on the Chilliwack River. A typical section about a mile west of monument 48 is as follows:

Top (?) unconformably overlain by Cretaceous (?).

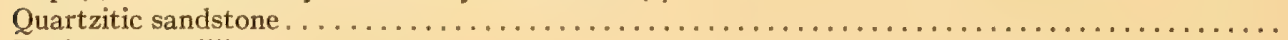

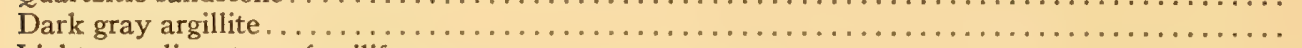

Light gray limestone, fossiliferous . . . . . . . . . . . . . . . . . . . . . . . . . . .

Gray calcareous quartzite and dark gray calcareous argillite. . . . . . . . . . . . . . . . . .

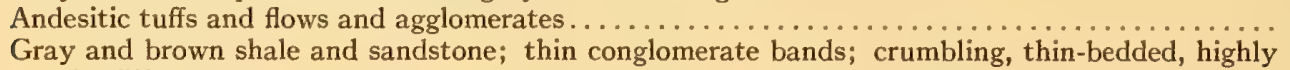

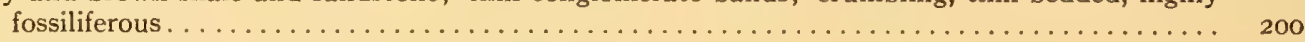

Light gray, generally crystalline limestone, fossiliferous . . . . . . . . . . . . . . . . . . . $600 \pm$

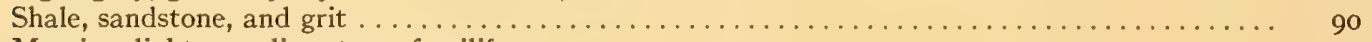

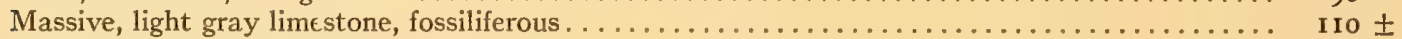

Dark gray and brown shales, fossiliferous. . . . . . . . . . . . . . . . . . . . . . . . . . . . . .

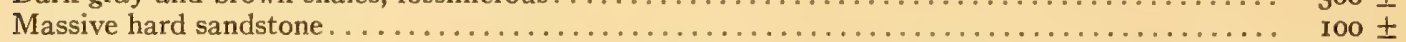

Hard sandstone and black and red shales with bands of grit and thin beds of conglomerate;

roughly .....................................................

Hard, massive sandstone with gritty layers . . . . . . . . . . . . . . . . . . . . . $800 \pm$

Dark gray to black, often phyllitic argillite with quartzitic bands . . . . . . . . . . . . . . . .

The 2,000 feet of andesitic tuffs and flows and agglomerates near the top constitute the Chilliwack volcanic series.

Girty, after listing the fossils obtained from above and below the Volcanic series (pages 5IO-5I3), says:

"On the whole, from the little that I understand of the stratigraphic relations and from the relationship manifested by the most marked of your faunas with that of the Nosoni formation, I am disposed to correlate all your beds in a general way with the latter. They may contain measures younger or older than the Nosoni, but from the absence of the well-marked Baird and McCloud facies it seems probable that none of the horizons from which your collections came is as old as the McCloud."

In the Hozomeen Range east of the Skagit Range the Hozomeen series is typically developed; because of the absence of fossils its position is uncertain, but it is provisionally correlated by Daly with the Cache Creek series for reasons given on pages $502-504$ of his Memoir No. 38 .

The series is composed of quartzite, chert, limestone, and dominant greenstone. The limestone occurs as rare intercalations of white or pale gray rock squeezed into "pods" by later movements and deprived of all 
trace of the original bedding planes. While Daly regards it as not safe to assign any definite age to the three dominant series, he says:

"It seems best to believe, as a working hypothesis, that the Hozomeen greenstone and limestone are younger than the principal quartzite (phyllite) group and overlie the latter conformably."

On page 504 Daly says:

"It seems probable, therefore, that the Hozomeen series is to be correlated with the Anarchist series, and both of them, with Dawson's Cache Creek series as well as with the likewise fossiliferous Chilliwack River series."

Farther to the east through the Okanagan Mountains, Kruger Plateau, Midway Mountains, and the Anarchist Plateau (see plate 3, Memoir 38, and maps Io to 13 ), the Anarchist series, so far as made out, seems to represent the same horizon of the Carboniferous. It is largely phyllite, quartzite, limestone, and greenstone. The quartzite and phyllite are most abundant, then the greenstone and the limestone, in "pods."

"This oldest group is almost certainly the same as that which crops out at intervals between the Columbia River and Midway, and, in the Rossland district, bears obscure fossils referred to Carboniferous species. Though the lithological similarity of the Anarchist series to these Rossland rocks and, as we shall see, to the very thick, fossiliferous, undoubtedly Carboniferous rocks found in the Skagit Range, may be an accidental and illusory resemblance, it seems best to correlate the Anarchist series, or much of it at least, with the Carboniferous rocks of western British Columbia." (Page 422.)

In the center of the Columbia Mountain system between Christina Lake and Midway is exposed a series of argillites, quartzites, and limestone called by Daly the Attwood series. ${ }^{1}$ This resembles the Cache Creek of the Kamloops district. The limestone is generally white and crystalline, but occasionally drab or black, the argillites are or were carbonaceous. The sediments "probably form part of a once extensive series of sediments which covered southern British Columbia." Daly agrees with Brock in correlating this series with the fossiliferous (probably Carboniferous) series of argillites, quartzites, and limestone in the Rossland Mountains.

In the Rossland Mountains, and especially in the Little Sheep Creek Valley, there are fossiliferous limestones, cherts, and quartzites, and in the Pend d'Oreille region phyllites, quartzites, limestones, etc. In the Little Sheep Creek Valley there is a blue-gray to white limestone, brecciated, and with lenses of chert and quartzite. In the breccias have been found Carboniferous fossils (Lonsdalia).

In the Selkirk Range the Pend d'Oreille group includes greenstone, phyllite, amphibolite, etc. The rocks are similar, lithologically, to those found in the Rossland district, and in central Idaho Lindgren ${ }^{2}$ found closely similar rocks in isolated areas, the Wood River series, which carry Carboniferous fossils.

1 Memoir 38, p. 382, and R. W. Brock, Annual Report Canadian Geological Survey, p. 96, 1902.

${ }^{2}$ Lindgren, W., The Gold and Silver Veins of Silver City, etc., 20th Annual Report U. S. Geological Survey, pt. III, pp. 85-90, I900. 
About Ioo miles to the north and northwest of the boundary section at the Pend d'Oreille are found considerable areas of stratified rock which Brock referred to the Cache Creek series, or the Slocan series, which he regards as equal to the Cache Creek. ${ }^{1}$

In the Flathead Valley there is, according to Dowling, ${ }^{2}$ a "down-tilted block *** of Carboniferous limestone with reddish upper beds that may be Permian or Triassic in the higher members." This lies due south of Corbin, at the mouth of Squaw Creek.

At Blairmore, in the South Fork River coal area, MacKenzie ${ }^{3}$ describes a small area of pure and cherty limestone. Similar beds occur in the anticline of the Turtle Mountains. The age of this bed is uncertain, but is provisionally placed as Devono-Carboniferous.

On the eastern edge of the Rocky Mountain Front, in the Sheep Creek anticline, on Sheep Creek south of Clagary, Alberta, Dowling ${ }^{4}$ describes Mesozoic rocks and continues (page I49):

"It is quite certain that the floor on which the above-described Mesozoic deposits were laid down consists of a series of limestones of which the western portion is formed of Carboniferous rocks with possibly some Triassic and Permian sediments lying here and there upon them."

"The Cache Creek formation, ${ }^{5}$ as shown on the present map and as now understood, must therefore be regarded as including a very thick series of Paleozoic rocks, of which the greater part is definitely referable to the Carboniferous period by means of its fossils, but of which it is scarcely probable that the upper and lower limits agree precisely with those of the typical Carboniferous. It may very possibly be found at the base, particularly, to transgress these limits and to include beds older than those of the system.

"In attempting a brief general description of this formation, it must in the first place be observed that the extremely broken and disturbed character of the rocks almost everywhere renders it next to impossible to learn much about their attitude or sequence in any one locality. It is very generally impossible to determine whether the dip of the beds is normal or has been overturned. It is thus only by following the general association of the rocks from place to place and by piecing together facts observed at many different places that it becomes practicable to outline the salient features of the whole.

"The western part of the Kamloops sheet, between the Thompson and Bonaparte Rivers on one side and the Fraser on the other, is the typical area for the

${ }^{1}$ Brock, R. W., Explanatory Note to the West Kootenay Map Sheet, Canadian Geological Survey, 1902.

${ }^{2}$ Dowling, D. B., Coal Areas in the Flathead Valley, British Columbia, Summary Report of the Geological Survey of Canada for I9I3, p. I39, I9I4.

${ }^{3}$ MacKenzie, J. D., South Fork Coal Area, Oldman River, Alberta, Summary Report Canadian Geological Survey for 1912, p. 235, 1913.

${ }^{4}$ Dowling, D. B., Geological Notes on the Sheep River Gas and Oil Field, Alberta, Summary Report Canadian Geological Survey for 1913, p. 145, I9I4.

5 This account is taken from Professional Paper No. 7I, United States Geological Survey, page 390. It is a condensation of reports by G. M. Dawson, Report on the Kamloops Sheet, British Columbia, Annual Report of the Canadian Geological Survey, new series, vol. 7, page 39, I896, and Duplication of Geologic Formation Names, Science, n. s., vol. 9 , page 592, I 899 . 
Cache Creek formation, and the most definite feature which can be traced throughout is the belt of massive $* * *$ and whitish limestones, sometimes marbles. $* * *$

"Practically the entire mass of the Marble Mountain Range is composed of these limestones, as well as the whole eastern part of the Pavilion Mountains. They include comparatively insignificant intercalations of argillite, cherty quartzite, and materials of volcanic origin. Farther south, in the region to the east of Hat Creek, such materials become more abundant and form thick beds among the limestones, particularly the cherty quartzites and the greenstones. In this region it is probable that the lower part of the great limestone series is most prominently displayed and that the higher beds are more characteristic in the north, particularly in the Marble and Pavilion Mountains. The earlier stages of the great period of limestone deposition appear to have been marked by frequent interruptions, during which argillaceous and volcanic products were laid down; while in its later stages the deposition of the limestone must have been almost unbroken. The interlocking of the different classes of materials is such, however, as to show the close connection which obtains between the Marble Canyon limestones and the lower parts of the Cache Creek formation. ***

"The extremely unsatisfactory condition of the rocks of the Cache Creek series for all purposes of measurement [is such that] in endeavoring to give some idea of the total volume of the formation, no even approximately correct data can be quoted. The subjoined summarized section is therefore merely an attempt to indicate the general order of succession, and to some extent the importance of the formation, in the western part of the area of the [Kamloops] map. The order is descending.

I. Massive limestones (Marble Canyon limestone), with some minor intercalations of volcanic rocks, argillites, and cherty quartzites. At least $\mathrm{r}, 000$ feet seen in some single exposures. Total thickness probably at least. . . . . . . . . . . . . . . . . . . . . . . . . . . . . .

2. Volcanic materials and limestones, with some argillites, cherty quartzites, etc. Minimum thick-

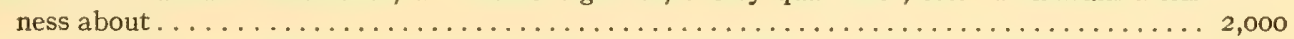

3. Cherty quartzites, argillites, volcanic materials, and serpentines, with some limestone. The thickness of these beds, or of a part of them, was roughly estimated in two places as between

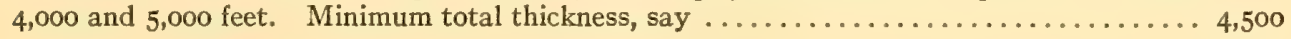

"Thus, the entire volume of the rocks of the Cache Creek formation, as this is now defined, may be assumed to be about Io,ooo feet as a minimum, while I am inclined to believe that it really exceeds $\mathrm{I}_{5}, 000$ feet.

"A few characteristic fossils have been obtained in a number of places beyond the limits of the present map. At Stuart Lake (latitude $54^{\circ} 30^{\prime}$ ), Dease River (latitude $59^{\circ} \mathrm{I} 5^{\prime}$ ), Frances River (latitude $60^{\circ} 30^{\prime}$ ), and on Tagish Lake (latitude $\left.60^{\circ}\right)$, fusuline limestones have been observed.

"To the westward of the Coast Ranges (in which it is probable that numerous infolds of Paleozoic rocks will yet be found) a formation known from its fossils to be of Carboniferous age is again well represented. This has, so far, not been very minutely examined or reported in detail, but it is known to comprise thick beds of limestones, argillites, and volcanic materials, the latter being even more characteristic and in greater development than in the region here specially dealt with.

"In the Rocky Mountains proper, or eastern member of the Cordilleran system, the section which must now be regarded as the typical one for these latitudes is that worked out by Mr. R. G. McConnell. In this section the Carboniferous 
period is represented by the Banff lime series, which, including two shaly zones, has a thickness of 5, IOO feet. This has yielded a number of fossils and these show that the series as a whole represents the lower part of the Carboniferous, passing below into the Devono-Carboniferous. The later part of the Carboniferous period seems either to be unrepresented, or, if represented at all, to find but a partial equivalent in the upper shales. It is thus very probable that before the close of the Carboniferous the present position of the Rocky Mountains formed part of a land area.

"It has already been noted that the lower portions of the Cache Creek formation may be older than the Carboniferous period. The very general blending of the Carboniferous and Devonian systems in the West shows that no wellmarked line need be anticipated at the base of the Carboniferous. The separation of any beds of Devonian age can only be made in the event of the future discovery of characteristic fossils. The same may be said respecting the possible existence of Silurian or Cambro-Silurian beds."

In the Summary Report of the Canadian Geological Survey for I9I5, Camsell, ${ }^{1}$ writing upon the Stewart, Tacla, and Trembleur Lakes area and the Omeneca Placer district describes the rocks of the various regions. On Stewart Lake there is a massive blue limestone which carries Fusulina. This led Dawson ${ }^{2}$ to refer it to the Carboniferous. Below the limestone are cherty quartzites, argillites, and greenstone schist, the latter probably derived by alteration from volcanics. The beds are much disturbed and dip at high angles. On Tacla Lake to the north of Stewart Lake there are blue and gray sandstones and slates with small bands of dark-blue limestone. In near-by localities (Germania Creek and Manson River) are volcanic flows, tuffs, and breccias or chloritic schists and slates with narrow bands of ferruginous dolomite. These beds are correlated with those of the Stewart Lake area by lithological and structural characters only.

(The similarity of limestone here described and its position above the series of metamorphic sediments and volcanics, to the limestone on the western side of the great bathylith is at least striking and suggestive.)

In the Bridge River Map Area near Chilkas Lake, Drysdale ${ }^{3}$ has described Paleozoic rocks which he calls Devono-Carboniferous and places in the Cache Creek Series. He gives the following section:

White Cap schist series $8,000 \pm$ feet. Quartzite, mica schist, andalusite schist, squeezed conglomerate and sandstone, phyllite, talcosic, sericitic, and chloritic schist.

Bridge River series $9,500 \pm$ feet. Mainly contorted chert and cherty quartzite. Red arenaceous schist, metargillite, and crystalline limestone in lenses. Flows of basalt mainly near the top.

${ }^{1}$ Camsell, Charles, Exploration in the Northern Interior of British Columbia, Summary Report Canadian Geological Survey for 1915, p. 70, I916.

${ }^{2}$ Canadian Geological Survey, Report of Progress, I87 I-77, p. 55.

${ }^{3}$ Drysdale, C. W., Bridge River Map-area, Lillooet Mining Division, British Columbia, Summary Report Canadian Geological Survey for 1915, p. 75, 1916. 
In the Lillooet map area ${ }^{1}$ and in the area between Lillooet and Chilkas Lakes practically the same series occurs, according to Bateman.

If any part of this section is Carboniferous it is the White Cap series, which has been very seriously affected by the great bathylithic intrusions to the west.

The Highland Valley Copper Camp, Ashcroft Mining Division, near Kamloops Lake, shows, according to Drysdale, ${ }^{2}$ the Cache Creek series, including cherty quartzite, argillite, greenstone, and limestone (Marble Canyon limestone). This is lithologically near to the Bridge River series and possibly represents the lower part only, being Devonian in age. ${ }^{3}$

Drysdale, in the last-cited paper, after giving the section on the Thompson River near Kamloops Lake quoted above, makes some remarks, page I32, upon the-

"Conditions of deposition.-The rocks belonging to the Cache Creek formation were probably laid down in a Carboniferous sea ('Vancouver Continental Sea'), slowly transgressing from the northwest upon a low-lying area ('Cascadia' positive element) which probably supported abundant vegetation. In this continental sea, argillaceous, arenaceous, and calcareous sediments were deposited. The limestones represent the off-shore deposits, whereas the carbonaceous argillites and sandstones represent the inshore phases.

"Marine sedimentation was interrupted at intervals by volcanic activity, which resulted in the accumulation of much volcanic dust and the outpouring of lavas."

He also remarks upon the "age and correlation," from which the following is summarized. Fossils have been found in the Cache Creek series near Thompson River (on the Caribou Wagon Road, 2.5 miles above the 89-mile stable) which belong between the base of the Devonian and the top of the Permian. Beyond this region to the north Fusulina has been found at Stewart Lake, latitude $54^{\circ} 30^{\prime}$, Dease River, $59^{\circ} 15^{\prime}$, Frances River, $60^{\circ} 30^{\prime}$, and Tagish Lake, $60^{\circ}$.

The Cache Creek series may be correlated with the Attwood series of Daly (Memoir 38, Canadian Geological Survey), and the upper part of the Brooklyn limestone of Phœnix ${ }^{4}$ and the Gloucester limestone of Franklin. ${ }^{5}$ With the existence of an angular unconformity above this series and below

${ }^{1}$ Bateman, A. M., The Lillooet Map-area, British Columbia, Summary Report Canadian Geological Survey for 1912, p. 188 .

Exploration between Lillooet and Chilkas Lake, British Columbia, idem, p. 177.

2 Drysdale, C. W., Highland Valley Copper Camp, Ashcraft Division, British Columbia, Summary Report Canadian Geological Survey for I9I5, p. 89, I9I6.

${ }^{3}$ For further description of this region see:

Dawson, G. M., Annual Report Canadian Geological Survey, vol. 7, p. I-427B, I 896.

Drysdale, C. W., Geology of the Thompson River Valley below Kamloops Lake, British Columbia, Summary Report Canadian Geological Survey for I9I2, p. I I5, I9I3.

"LeRoy, O. E., The Geology and Ore Deposits of Phœnix, Boundary District, British Columbia, Memoir 2I, Canadian Geological Survey, I9r2.

${ }^{5}$ Drysdale, C. W., Geology of Franklin Mining Camp, British Columbia, Memoir 56, Canadian Geological Survey, pp. I4, I44, I9I5. 
the Triassic it is at least possible that the massive limestones described are a continuation of the one to the north assigned to Gschelian age by Girty.

At Banff in Alberta the upper Carboniferous and Permian (?) are represented by: ${ }^{1}$

The Upper Banff Shale.-This is a series of brown, calcareous and often arenaceous shales, lying conformably upon the quartzite below. It is often sun-cracked and is interbedded with thin layers of sandstone. A very common fossil is Schizodus.

The Rocky Mountain Quartzite.-A clean quartzite which represents a sudden shallowing of the water which did not become muddy. This formation is about 800 feet thick at Banff, but thickens rapidly to the east, so that at Lake Minnewanka, I2 miles east, it is I,600 feet thick.

The Upper Banff Limestone.-This is shaly at the bottom, but more massive near the top. The lower shaly portion has cherty lenses and cherty shales interbedded with the limestone.

The Upper Banff shales have been shown by Lambe and Kindle to be probably of lower Triassic age:

"The Upper Banff shale has been referred in some of the recent reports of this Survey to the Permian. Since the original reference of the Upper Banff shale to the Permian was of a provisional character it has seemed desirable to reexamine the question of the age of these beds in the light of additional evidence of the last season's collections. I have accordingly brought together all of the available collections from these beds, including Professor Shimer's collection from the Lake Minnewanka section, and referred them to Dr. Geo. H. Girty of the United States Geological Survey, who has a wide acquaintance with the faunas of this and related horizons in the Rocky Mountains of the United States. Dr. Girty concludes that these faunas represent the horizon of the Lower Triassic (Meekoceras beds) of Idaho, Utah, and Wyoming. If this opinion is correct, as I believe it to be, the reputed Jurassic beds from which the fossil fish transmitted to you were obtained and the 'Permian' of the Banff map as well should be referred to the Triassic. Inasmuch as most of the species in this fauna are new, this determination will have to rest for the present on evidence of a somewhat general character." 2

The evidence for the Permian age of these beds is set forth by Shimer, ${ }^{3}$ Burling, ${ }^{4}$ and Lambe. ${ }^{5}$

1 Allan, J. A., Rocky Mountain Section Between Banff, Alberta, and Golden, British Columbia, along the Canadian Pacific Railway, Summary Report Canadian Geological Survey for 1912, p. 173, 1913. Rocky Mountains, Guide Book No. 8, pt. II, p. 183, I913, issued by the Geological Survey, Ottawa, I9I3.

${ }^{2}$ Kindle, E. M., in Lambe, Ganoid Fishes from near Banff, Alberta, Trans. Royal Society of Canada, series 3, vol. I0, p. 37, I916.

${ }^{3}$ Shimer, H. W., Lake Minnewanka Section, Alberta, Summary Report Canadian Geological Survey for 1910, pp. 145-I49, I9I I.

${ }^{4}$ Burling, L. D., Notes on the Stratigraphy of the Rocky Mountains, Alberta and British Columbia, Summary Report Canadian Geological Survey for I915, pp. 97-110, I916.

' Lambe, L. M., Description of a New Species of Platysomus from the neighborhood of Banff, Alberta, Trans. Royal Society of Canada, vol. 8, p. 17, 1914. 


\section{CHAPTER VI.}

\section{THE LATE PALEOZOIC IN ALASKA.}

While our knowledge of the geology of Alaska is still very imperfect, reconnaissance work has gone so far that we may say with some confidence that no rocks of true Permian age exist in that region and none, with the possible exception of certain series in the southeastern portion, which may represent the interval of time recorded in the "Permian Red Beds" of the southwestern United States. The series reported in the earlier reports as Permian have one after the other been shown by their invertebrate fauna to be lower in the series, as their fossils have very decided affinities with the Gschelian, upper Pennsylvanian, stage of Russia rather than with the true Permian.

It is, as yet, impossible to delimit the areas of deposition either stratigraphically or geographically with any certainty or to give any thing more than a very approximate account of the conditions of deposition, but a very general idea of the prevailing conditions at the end of the Paleozoic may be offered with some confidence in the accuracy of the broad outlines.

The following statement from Brooks ${ }^{1}$ is an excellent introduction to such a description:

"The records of the succeeding epoch are obscure, but indicate that limestone deposition continued in some places during early Carboniferous times, while in others a considerable land area was exposed to erosion. Deposition was probably almost entirely checked by a crustal movement which took place about the beginning of the Permian, and this was followed by subsidence. On the Yukon there is evidence of an extensive period of erosion which immediately antedated the deposition of the Permian sediments, but this has not been recognized elsewhere.

"The Permian sea seems to have covered much the larger part of the province, for its sediments have been found along the Yukon, in the Panhandle, and in the Copper Basin, where they aggregate 7,000 to 8,000 feet. In the two latter districts the deposition apparently continued unbroken into the Triassic and was characterized by a gradual change from limestones to shales. It was ended by a crustal movement which deformed the beds, exposed a considerable landmass, and thus began another period of erosion. This uplift seems to have begun in Permian times in northern Alaska and progressed gradually southward during Triassic times, for the latter period does not seem to have left any sedimentary record north of the Pacific Mountains. In southeastern Alaska the indications are that the Permian-Triassic cycle of deposition was closed by an extensive

${ }^{1}$ Brooks, Alfred H., The Geography and Geology of Alaska, U. S. Geological Survey, Professional Paper No. 45, p. 265 , 1906. 
dynamic revolution which metamorphosed and deformed the Paleozoic sediments and probably left them very much as they are now."

On page 224 of the same paper Brooks makes the following statement:

"A belt of Carboniferous rocks (probably Permian) has been fairly well traced throughout southeastern Alaska; the continuation of the strike of these would carry them into the White, Tanana, and Copper River basins, where there is a very extensive development of Permian beds and also some lower Carboniferous rocks; Permian beds have also been found on the Yukon, near the Arctic Circle, resting unconformably on strata of lower Carboniferous age. In northern Alaska the presence of two Carboniferous horizons is established by fossil evidence, though there is little definite knowledge of their extent or stratigraphic and structural relations. In all except this northern field igneous intrusives are found cutting the Carboniferous rocks, and in southeastern Alaska it is probable that some of the associated greenstone schists are ancient lava flows. In the Copper River basin volcanic rocks are characteristic accompaniments of the sediments referred to the Permian [Upper Pennsylvanian]."

It will be noted that Brooks speaks freely and with some degree of certainty of the age of the rocks which he regards as Permian, but, as is shown by the quotations given below, it is altogether probable that these rocks are of a lower horizon equivalent to the Gschelian of Russia, and such a correction has been inserted parenthetically in the quotation from his paper.

Following are given characteristic sections and descriptions of some of the better-known areas which will serve to illustrate the conditions which prevail in the Alaskan Province.

Rocks originally considered as of Permian age are known from the Panhandle and from all of southeastern Alaska at intervals from the lower end of the Alexander Archipelago to the headwaters of the Copper River. Wright and Wright ${ }^{1}$ give the following succession:

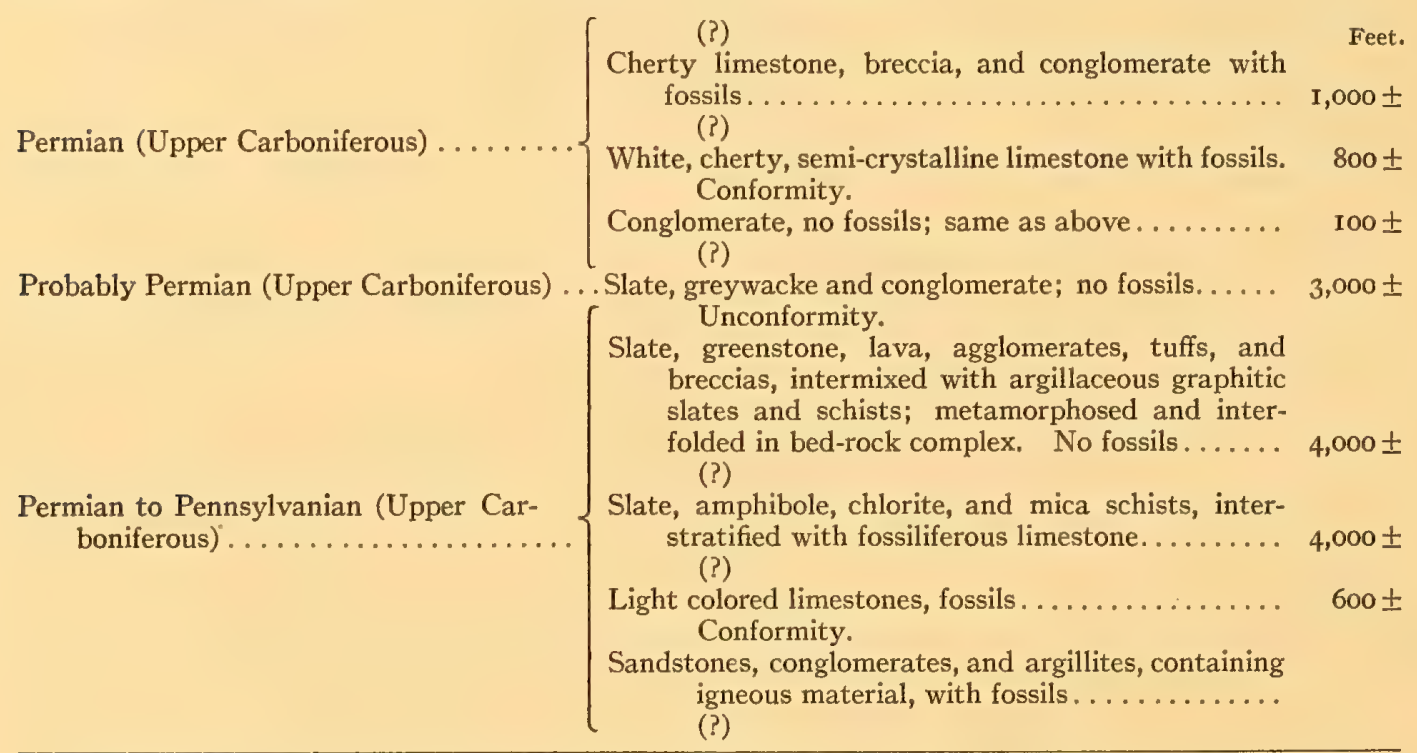

${ }^{1}$ Wright, F. E., and C. W. Wright, The Ketchikan and Wrangell Mining Districts, Alaska, U. S. Geological Survey Bull. No. 347, p. 34, 1908. 
The four members of the last series are typically exposed; the first, on the west coast of Baranoff Island, Chicagoff Island, Douglas Island, Gravina Island, and the Cleveland Peninsula; the second, near Taku Harbor and George Inlet; the third, at Saginaw Bay on Kuiu or Kiku Island; the fourth, at Soda Springs Bay. The upper series (Permian) (Upper Pennsylvanian) is well shown at Hamilton Bay, on the Screen Islands, and at Pybus Bay, where the rocks are steeply tilted, folded, and metamorphosed; the middle series occurs at Sitka, Cape Edward, Douglas Island, and the Glass Peninsula, and the rocks of this series are also tilted, folded, metamorphosed to a schistose condition, and indurated. Fossils from the upper series of rocks were examined by Girty, who records his opinion in the Bulletin cited, page 53, that though they have been previously determined as of Permian age in the Alaskan Range, he regards them as rather lower in position. Of the two upper series he says:

"These two series, but especially the upper, are what have previously been determined as Permian in the Alaska Range, but I really find that the resemblance with the Gschelian stage of the Russian section is greater than with the Russian Permian. Provisionally, therefore, I will correlate this horizon with the Gschelstufe, in which occur a great number of equivalent or identical species. This fauna is entirely unlike anything in the Mississippian Province of the United States, but some of our western faunas resemble it."

This fauna is the same as is found in the McCloud formation of northern California.

As this fauna is quite similar to others collected in the same general region, the remarks quoted above might be applied to the whole of the heavy limestone in the Admirality Islands. A faunal list is given on pages 52 to 55 of Bulletin 347, United States Geological Survey.

Wright and Wright, speaking of the Upper Carboniferous as including the Permian, say that argillites were extensively laid down at the end of the Carboniferous, which indicates an elevation of the land at the close of the Permian (?) in some adjacent region (probably to the north and eastCase), and that a period of volcanic activity of long duration ensued. "The beds of lava and ash ejected from the volcanic vents were contemporaneous with the slate beds, and because of their intimate association with the sediments of volcanoes are regarded as submarine intrusives." The series of limestones, and with the associated argillites, greenstones, schist, etc., the Ketchikan series, extends in a generally northwest direction toward St. Elias. Brooks states that Wright found doubtful Permian fossils in the Porcupine placer gold district in southeastern Alaska, but in Wright's report ${ }^{1}$ I find only mention of Mississippian fossils. On the slopes of the Alaska Range the same series occurs.

${ }^{1}$ Wright, C. W., The Porcupine Placer District, Alaska, U. S. Geological Survey Bull. 236, 1904. 
From the Nabesna and White Rivers, Moffit and Knopf ${ }^{1}$ reported the following section:

Massive limestone.

Shale, some tuffs, and lava flows.

Basic lava and pyroclastic beds with some shale and limestone beds.

The upper member, the massive limestone, is the one traced by Brooks along the north base of the St. Elias Range to the Nabesna River through the White River Basin (Professional Paper 45, p. 222.)

In the Chisana-White River District Capps ${ }^{2}$ reports,

Lava and pyroclastic beds, with some shale.

Massive limestone with shale, thin bedded limestone and a little sandstone and conglomerate.

Lava and pyroclastics with a small amount of sediment.

Massive limestone of Skolai Creek with interbedded lava and minor amounts of shale and conglomerate.

Basic bedded lavas with little sedimentary material.

The lower part of this section may be Devonian or Lower Carboniferous as the Devonian shades into the Carboniferous; the upper two members of the section are probably Pennsylvanian (Permian). The upper part of the section is closed by an unconformity.

The fossils are from one general zone "which seems the same zone as that near Circle City described by Spurr (Takhandit series) or a closely related one. I have made no specific determinations, since the fauna is not to be correlated with the Upper Carboniferous of the Mississippi Valley, but with the Fusulina zone of China, India, and the eastern slopes of the Urals." 3

Abundant fossils were collected in the Nabesna-White River region, which were mostly referred by Girty to the Russian Gschelian. ${ }^{4}$ It is very probable that the massive limestone is the same as that in the Panhandle, which has been traced into this region, and that the two lower series are the equivalent of the lower beds in the same region. ${ }^{5}$

In general, Carboniferous rocks make up the north flank of the St. Elias Range between the White and the Nabesna Rivers. Most of the pyroclastic rocks were laid down in water, for they are in places interbedded with sediments and locally contain fossils. It is probable also that some of the lavas were discharged into the sea and cooled under water. The tuffs and breccias are made up of material which was ejected violently from volcanoes and which fell into bodies of water, there to be deposited in

${ }^{2}$ Moffit, F. H., and Adolph Knopf, Mineral Resources of Nabesna-White River District, Alaska, U. S. Geological Survey Bull. 417, p. I6, 1910.

${ }^{2}$ Capps, S. R., The Chisana-White River District, Alaska, U. S. Geological Survey Bull. 630 , p. 39, 1916.

${ }^{3}$ Girty, Geo. H., in Bulletin 630, just cited, p. 45.

${ }^{4}$ Moffit, F. H., and Adolph Knopf, Mineral Resources of Nabesna-White River District, Alaska, U. S. Geological Survey Bull. 4I7, p. 20, I9I0.

${ }^{5}$ Idem, pp. 24-27. 
company with shales, sandstones, and flows of lava that entered the sea and cooled. The pyroclastic beds are composed of angular fragments of rocks, little decomposed, and contrasted with the materials derived from the decomposition and erosion of land-masses, carried by streams or oceancurrents and deposited to form ordinary sandstone and shale. The shales are black to bluish and gray. All gradations occur from typical fine-grained black shale through limy shale to impure argillaceous limestone and fine sandy shale to sandstone.

In the central Copper River district, Mendenhall ${ }^{1}$ reports Permian (?) sandstone, shale, and limestone 6,000 to 7,000 feet thick, with included intrusive sheets and some pyroclastics. His section is as follows:

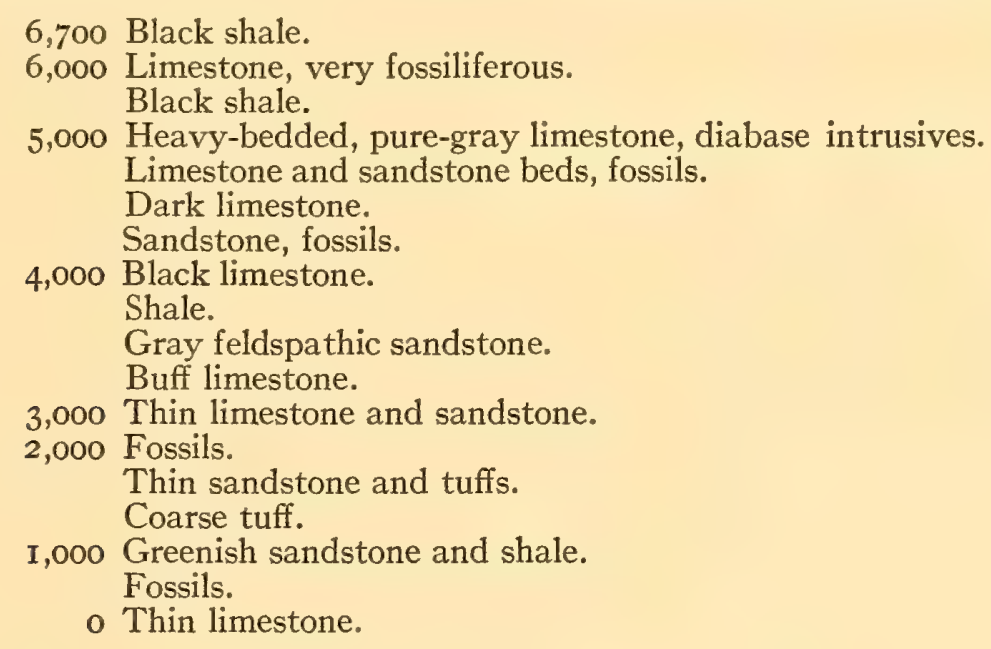

This section was made in an isolated mass cut off from the rest of the country by a fault, but it is probably of the same Gschelian, and lower, age as the Ketchikan series. Mendenhall considers this series equal to the Chitistone limestone of Schrader and Spencer and the Nabesna limestone of Schrader. It is very probable that the upper prevailingly calcareous part is to be reckoned as Gschelian in age and the lower arenaceous and tufaceous part as lower Carboniferous.

Similar deposits are found in the Kenai Peninsula. On the headwaters of the Gulkana and Susitna Rivers, Martin, Johnson, and Grant ${ }^{2}$ and Moffit ${ }^{3}$ record Carboniferous slate, tuff quartzite, and limestone. In the Hanagita-Bremmer region Moffit ${ }^{4}$ records Carboniferous (?) schist, slate, and limestone. Many beds of limestone are from Ioo to 200 feet thick.

${ }^{1}$ Mendenhall, W. C., Geology of the Central Copper River Region, Alaska, U. S. Geological Survey, Professional Paper No. 4I, p. 40, 1905.

${ }^{2}$ Martin, G. C., B. F. Johnson, and U. S. Grant, Geology and Mineral Resources of the Kenai Peninsula, Alaska, U. S. Geological Survey Bull. 587, I9I 5.

${ }^{3}$ Moffit, F. H., Headwater Regions of Gulkana and Susitna Rivers, Alaska, U. S. Geological Survey Bull. 498, I912.

${ }^{4}$ Moffit, F. H., Geology of the Hanagita-Bremmer Region, Alaska, U. S. Geological Survey Bull. 576, I9I4. 
The earliest history of this whole region (Nabesna, White, Copper, and Chisna Rivers) -

"shows that marine conditions prevailed throughout the region, but that the normal course of sedimentation was repeatedly interrupted by the extrusion of andesitic and basaltic lavas and the ejection of tuffs and breccias. Where the accumulation of ordinary clastic sediments went on uninterruptedly, sandstones, shales, and limestones were laid down, and now bear evidence in their wealth of fossil remains, that the seas teemed with life, among which huge zaphrentoid corals flourished in great abundance. The marine occupation appears to have continued until early Mesozoic time." 1

In central Alaska, Prindle ${ }^{2}$ reports Permian or Pennsylvanian rocks in the Fairbanks and Rampart Quadrangles of the Yukon-Tanana region. These consist of gray, greenish and black shale with siliceous beds. . Prindle, ${ }^{3}$ writing upon the Fairbanks Quadrangle, gives the following list: Gray and black shale, with some chert, and probably some limestone resting unconformably on the beds below. This series is regarded as equal to the Nation River series of the Yukon, but may be equal in time to the unconformity between the Nation River and the Calico Bluff (Mississippian).

Brooks and Kindle ${ }^{4}$ report for the Upper Yukon a heavy limestone (Gschelian in age) unconformably above a mass of sandstone and shale, $3,700 \pm$ feet thick, with fragments of plants and some small seams of bituminous coal. There are two layers of conglomerate, one at the base, very massive, and a second, not so heavy, about I,000 feet above the base.

Invertebrates are reported from a heavy limestone just below an unconformity in the Upper Yukon region, which Girty considers as Gschelian in age, the same fauna as at Pybus Bay, Kuiu Island. The rocks are not metamorphosed in this region and there is no evidence of volcanic activity, except at Glenn Creek.

In the upper part of the Tanana Basin, Schrader ${ }^{5}$ reports Permian fossils in the Suslota limestone, which lies above the Nabesna limestone.

Keele $^{6}$ and Camsell ${ }^{7}$ found a limestone between the Peele and Stewart Rivers which is probably the equivalent of the massive limestone of the Yukon area. This limestone is a "massive, granular limestone containing

${ }^{1}$ Moffit, F. H., and Adolph Knopf, Mineral Resources of the Nabesna-White River District, Alaska, U. S. Geological Survey Bull. 417, p. 47, I9I0.

${ }^{2}$ Prindle, L. M., The Fairbanks and Rampart Quadrangles, Yukon-Tanana Region, Alaska, U. S. Geological Survey Bull. 337, 1908.

${ }^{3}$ Prindle, L. M., A Geologic Reconnaissance of the Fairbanks Quadrangle, Alaska, etc., U. S. Geological Survey Bull. 525, I913.

4 Brooks, A. H., and E. M. Kindle, Paleozoic and Associated Rocks of the Upper Yukon, Alaska, Bull. Geol. Soc. Amer., vol. 19, p. 255, 1908.

${ }^{5}$ Schrader, F. C., Recent Work of the United States Geological Survey in Alaska, Bull. Amer. Geog. Soc., vol. 34, pp. I-I45, I902.

${ }^{6}$ Keele, Jos., Report on the Upper Stewart River Region, Yukon, Annual Report Canadian Geological Survey, vol. 16, pt. c., p. 14, 1906.

${ }^{7}$ Camsell, Chas., Report on the Peele River and Tributaries, Yukon and Mackenzie, Annual Report Canadian Geological Survey, vol. I6, pt. CC, p. I6, I906. 
fossils." Keele refers to it as a "mass of white, bedded, crystalline limestone forming the greater part of a mountain group."

Dawson found a siliceous crystalline limestone on Tagish Lake which he considered as Carboniferous and correlated with the Cache Creek series. (Canadian Geological Survey, r887, part B, p. I7oB-I7IB.) This limestone has been shown by later work of Dawson, Gwillen, and Kindle to be very doubtful in position and unsafe for use as any basis of conclusion.

The following summary statements are given by Mendenhall, and by Brooks and Kindle. Mendenhall ${ }^{1}$ says:

"We have seen that the earlier and middle Paleozoic history seems to have been largely continental - that of a land-mass, or its shore-lines, with coarse sediments and volcanic materials; but with the end of the Paleozoic the sea invaded the province through a general subsidence following the outflows of the Nikolai greenstone, and although no doubt varying in depth and shifting its outlines, practically maintained control until the middle of the Mesozoic.

"In the northern part of the province the sea seems to have only gradually invaded the land areas. The earliest Permian sediments there are shore deposits in part, and include sands, tufaceous beds, and flows, which denote the dying out of the earlier eruptive epoch, perhaps the last feeble activity of the Tetelna stage. But toward the middle of the period represented by the Permian rocks truly marine conditions prevailed and abundant marine life existed, while heavy limestones and fossiliferous black shales were being laid down in what is now the upper Copper River Valley. It is probable that this Permian sea was widespread in eastern Alaska. Its records are preserved on the middle Yukon, in the Copper Valley, in the valley of the upper White, and east of there toward Pyramid Harbor. It extended also to southeastern Alaska, where, however, the recognized beds belonging to it are marine sandstones instead of limestone. The even, exclusively marine phase of the upper part of the deposits makes it wholly improbable that there existed at this time any marked relief where the present great ranges stand. They may have been mountains before the Permian and after, but probably not during this era.

"In the Chitina Valley a shallow sea held possession through the Permian epoch and well into the Triassic, the deposition of thin, dark limestones and black shales continuing uninterruptedly."

Brooks and Kindle say:2

"The Carboniferous of Alaska is represented by three stages, the first of heavy limestone partly Devonian and partly lower Carboniferous. This stage is succeeded by a series of rocks in the Yukon area which 'are made up of littoral and in part at least of fresh-water deposits, embracing some very coarse material and aggregating nearly 3,000 feet in thickness. This same epoch of deposition is probably represented in the White-Copper River region and in the Alaskan Range, where, however, it appears to form the base of the Carboniferous, indicating that, if the older limestone had ever been present in this area, it was removed by

1 Mendenhall, W. C., Geology of the Central Copper River Region, Alaska, U. S. Geological Survey, Professional Paper No. 41, p. 76, I905.

${ }^{2}$ Brooks, A. H., and E. M. Kindle, Paleozoic and Associated Rocks of the Upper Yukon, Alaska, Büll. Geol. Soc. Amer., vol. 19, p. 304, I908. 
erosion before the coarse sediments were laid down. The same horizon appears to be represented in southeastern Alaska by argillites. The third epoch of deposition is one of calcareous material, and here again there was an abrupt change, this time to deep-sea conditions and marked by the appearance of a new fauna. This Upper Carboniferous sea was probably widespread. Its thickest recognized deposits are found in southeastern Alaska, but it seems quite probable that the upper limestone member of the Cache Creek series was deposited in it. Sedimentation may have continued unbroken into Triassic times in the Yukon district, but in southeastern Alaska a period of erosion intervened between the highest Paleozoic and the lowest Mesozoic.'" 


\section{CHAPTER VII.}

\section{INTERPRETATION OF THE ENVIRONMENTAL CONDITIONS FROM THE EVIDENCE OF THE DEPOSITS.}

\section{A. PERMO-CARBONIFEROUS CONDITIONS VERSUS PERMO- CARBONIFEROUS TIME.}

From the preceding account of the stratigraphy of the upper Paleozoic it is evident that a distinct line may be drawn between the red beds and the beds beneath them in all of the provinces; it is equally clear that this line will not lie at equivalent stratigraphic levels in all places. If, as is assumed as the thesis of this paper, the red beds and their equivalents are indicative of new environmental conditions, then a clear distinction may be drawn between what has long been called Pennsylvanian and Permo-Carboniferous (Permian) time, and Pennsylvanian and Permo-Carboniferous conditions, and the two are not coincident in all places.

The convenience and relative ease of synchronizing definite time intervals with definite deposits for purposes of classification is obvious, but it is equally obvious that time is not the sole nor even the dominant factor in evolution. Environmental conditions are far more effective in determining the rate and direction of evolutional and distributional changes, and these conditions may migrate both vertically and horizontally, independent of natural or arbitrary divisions of time. To assume that similar conditions necessarily prevailed over large areas through even a minor interval of geologic time is to introduce a possible error of the first dimension. This warning is especially applicable in interpreting a series of terrestrial or semiterrestrial deposits. The evidence that changes in environment, climatic, physiographic, topographic, and organic, migrate across large areas is too full and conclusive to admit of any question that such processes are at work at the present time. That such changes might have originated and migrated in a strictly similar manner in past time is equally beyond question. When past time is considered it is evident that migration may have proceeded in a new direction, upward, for if the migration is a slow one the new conditions will reach any new localities at progressively later dates and will be recorded in stratigraphically higher deposits.

The advance of conditions fitted for a certain group of organisms might then be recorded in the stratigraphic series by observable changes which 
would be oblique to the beds; time and environment will not coincide, and to correlate widely separated groups of beds as synchronous in deposition because of a similarity, even approaching identity, in the fauna or flora would be a serious error.

The condition, or better, the changing conditions, of upper Paleozoic time, treated in a broad way, furnish an excellent concrete example of such a migration of environment both vertically and horizontally.

It is well known that under the influence of a major earth-movement the continent of North America was uplifted in a progressive way from east to west during upper Paleozoic time. ${ }^{1}$ Swamp and terrestrial conditions initiated in the east advanced toward the west, displacing the marine conditions even to the westernmost limits of the Plains Province and over the southern part of the Basin Province.

In this connection certain remarks made by $\mathrm{Lee}^{2}$ are of especial interest:

"During much of the Carboniferous period sea water covered large portions of the area now occupied by the mountains. Marine limestone of Pennsylvanian age is abundant in central and northern New Mexico and in central and western Colorado. It has been the belief of many geologists that open sea conditions prevailed in western America during the time that the coal measures were forming in the eastern and central parts of the continent. Statements are frequently made that 'in the western part of the United States there are no coal accumulations of this age (Pennsylvanian). ${ }^{3}$ There is unquestionably a large amount of limestone of marine origin in the rocks of Pennsylvanian age in the Southern Rocky Mountain Province, but there are also thin beds of coal and plant-bearing sedimentary rocks which indicate lowlands and coastal swamps in Pennsylvanian time. These have been found in New Mexico, near Socorro; in the mountains east of Albuquerque; near Santa $\mathrm{Fe}$ on the western slope of the main range; in the Pecos Valley between the mountain ranges; east of the main ranges near Las Vegas; and farther to the north in the Moreno Valley. Thin beds of coal of Pennsylvanian age have been reported from many places in central and western Colorado and in eastern Utah, both north and south of the Uinta Range. These coal beds are not thick enough to be of commercial value, but they prove that the physiographic conditions of the Rocky Mountain region during the early part of the Pennsylvanian epoch were not so different from those in eastern and central North America as many geologists have supposed. However, later in the epoch these coals were covered by the sea in which was formed the massive limestone of Pennsylvanian age in New Mexico and southern Colorado, which seems to indicate clear water and open sea conditions."

${ }^{1}$ Girty, G. H., Outlines of Geologic History, chap. vi, pp. 126-127, 1910.

Schuchert, Chas., Paleogeography of North America, Bull. Geol. Soc. Amer., vol. 20, chart of submergences and emergences and map of Lower Permian.

Ulrich, E. O., Revision of the Paleozoic System, Bull. Geol. Soc. Amer., vol. 22, chart on p. 343 .

${ }^{2}$ Lee, W. T., Early Mesozoic physiography of the Southern Rocky Mountains, Smithsonian Miscellaneous Collections, Vol. 69, No. 4, p. 4, I9I8.

${ }^{3}$ Schuchert, Chas., Textbook, p. 745. 
In the northwestern part of the continent this uplift was approximately paralleled in time by a disturbance which started in Alaska and advanced to the south as far as northern California. Pirsson and Schuchert ${ }^{2}$ say of this latter disturbance:

"While it appears that the greater part of the continent was not undergoing more than crustal warping in Pennsylvanian time, there seems to have been more decided unrest along the entire Pacific area from northern California into arctic Alaska. Here the limestones and calcareous shales of the Pennsylvanian and the early Permian are interbedded with much extrusive igneous material. The thickness in California is not less than 4,600 feet, with a maximum of 10,000 feet, while in the Copper River region of Alaska it is nearly 7,000 feet. The calcareous deposits often abound in fossils unrelated to those found elsewhere in North America; they are of the Pacific realm, while the life record of the eastern seas accords better with that of northern Europe, though in the main it is best regarded as constituting the North American province. Long after Pennsylvanian time had begun there was also decided crustal movement in western Colorado, Utah, and Arizona, and this is probably to be associated with the deformation of the Pacific border."

As shown in the summary description of Alaska, the limestones and calcareous shales of Alaska, British Columbia, and the Pacific coast involved

TABLE 3.-Abbreviated correlation table showing the rise of the red deposits from east to west in the stratigraphic series. Red beds or equivalent intervals lie above the horizontal lines in the table.

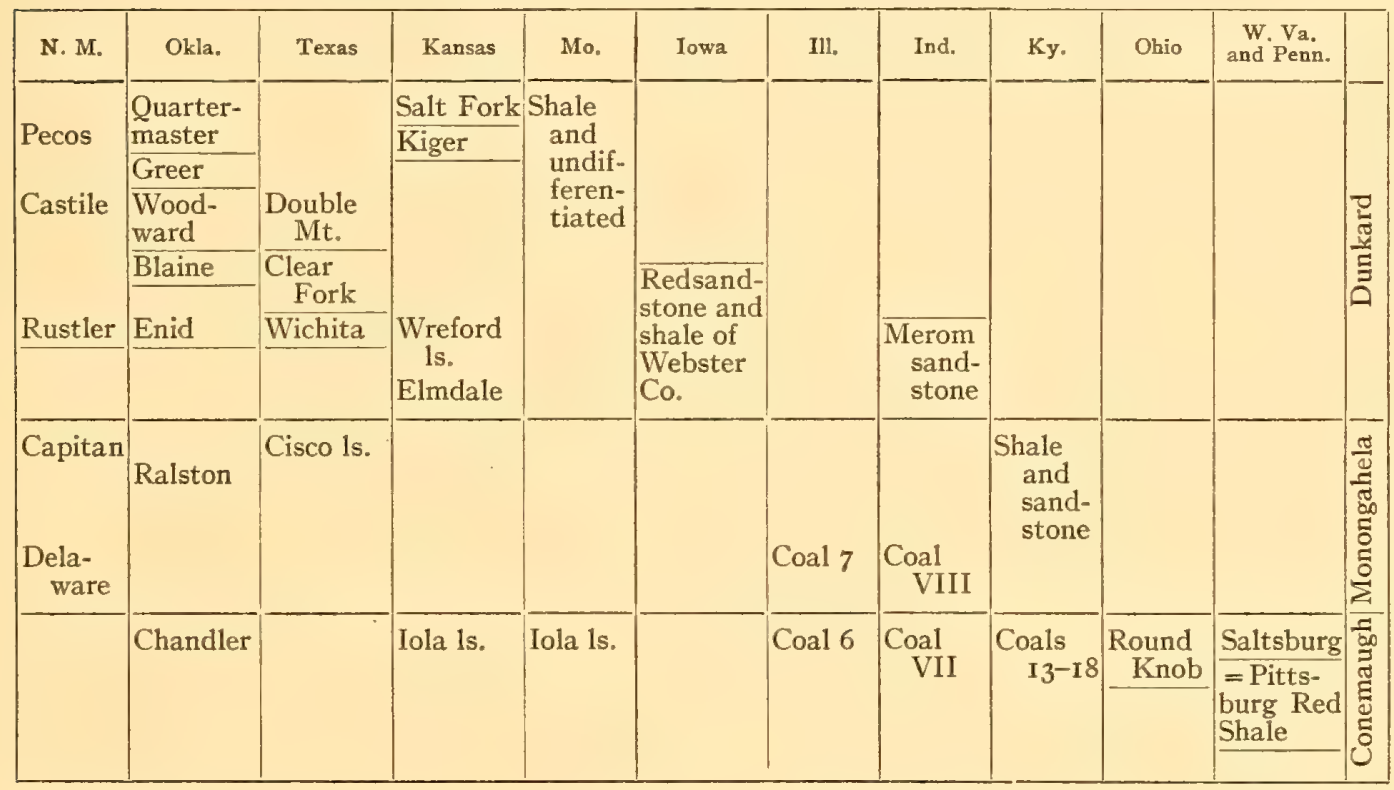

in this movement are not higher than the Russian Gschelian, and so earlier than the time of the formation of the red beds in the Western and Basin Provinces. Red beds and their equivalents, the Park City formation, can be traced into Montana, but the union of the two earth-movements seems to have raised the land north and west of this above the plane of deposition before the red-bed conditions (Triassic) reached that far west.

${ }^{2}$ Pirsson and Schuchert, A Text-Book of Geology, p. 744, I9I 5. 
As noted above, the progress of Permo-Carboniferous conditions during Pennsylvanian and Permo-Carboniferous time is marked by the disappearance of marine and swamp conditions and the appearance of more purely terrestrial deposits. The change from swamp to terrestrial deposition is marked more by the chemical condition than the physical character of the material-that is, the change was more in the climate than in mode of deposition.

As the climatic change was the most significant factor in the development of the land vertebrate life, and as its progress is most strikingly marked, it is taken as the key for the interpretation of the whole environmental migration.

As has been shown in the summary of the stratigraphy of the different provinces, in the correlation tables I and 3 , and in the accompanying schem-

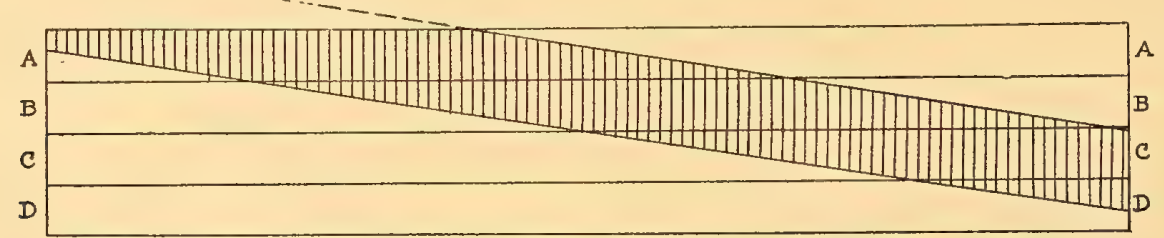

FIG. 5.-Diagram illustrating the record of a progressive wave of definite conditions advancing across an area in which continuous sedimentation is in progress. The upper and lower limits of the sediments deposited during the continuance of the definite condition will lie obliquely to the bedding planes. The upper and lower limits may be marked by unconformities or disconformities, but not necessarily.

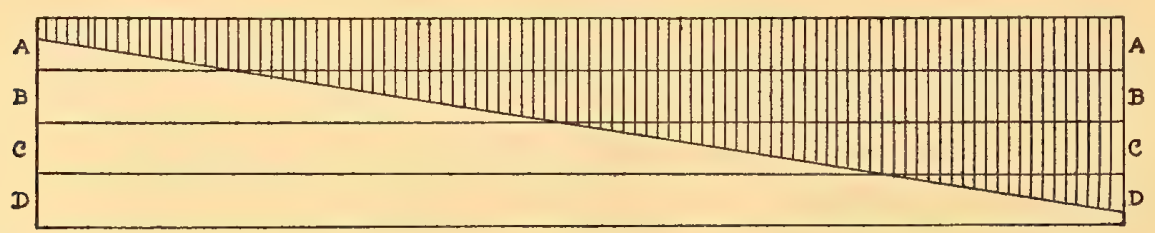

FIG. 6.-Diagram illustrating the record of a progressive extension of conditions which persist at the point of origin. The lower edges of the deposit formed during the definite conditions will be oblique to the bedding planes, but the upper edge may be straight, forming a wedge of the particular sediments, or the upper edge may be above the plane of erosion. Such a wedge will be formed only if sedimentation is continuous at the point of origin of the progressive conditions.

atic diagrams (figs. 5 and 6), the climatic change is recorded in conglomerates, glacial deposits, and red beds and can be clearly traced from east to west in a line ascending obliquely across the stratigraphic series from the middle of the Conemaugh in the Eastern Province to the base of the socalled Permian in the western provinces. The base of this series of red beds and conglomerates marks the beginning in each region of Permo-Carboniferous conditions, and the upper limit is lost by erosion or lack of deposition, or merges into the very similar Triassic deposits.

Permo-Carboniferous conditions in the Eastern Province are not coincident with Permian strata of current classification, but occur in a part of the Pennsylvanian strata as well; they encompass a definite period, however, 
marked by distinct environmental conditions, and the correlation of the strata within this time interval depends largely upon the recognition of the results of the operation of climatic factors.

The ideas here suggested are in decided variance with accepted methods of correlation, especially in the conception of the limitation and retardation of animal and plant migration by unfavorable conditions.

Ulrich says: ${ }^{1}$

"I have strong convictions respecting the great possibilities of correlation by a judicious application of organic criteria. Their greatest value in this connection arises from the demonstrable fact that, as a rule, the migration, and to a considerable extent also the evolution, of species, however slow, is yet relatively rapid as compared to the inconceivable length of geologic time.

"As to marine faunas, with which the student of Paleozoic stratigraphy is chiefly concerned, their migrations, when not prohibited by physical barriers, usually proceeded with such rapidity that their progress can not be expressed in recognizable units of the geologic time scale. Hence, unquestionable correlations by fossil evidence, fully checked by physical criteria, may be said to establish, so far as the practical purposes of geology are concerned, the essential contemporaneity of the beds so identified."

Ulrich's remarks are based upon the action of marine invertebrates almost entirely, but it will be noticed that the only influence that he recognizes as able to deter the rapid spread of such forms is the effect of "physical barriers." That there is an abundance of other barriers to migration and evolution will be evident at once to anyone who looks at the fossils as forms of life, subject in their time to influences strictly similar to those affecting living forms to-day.

The discovery of vertebrate fossils belonging to identical or closely related genera, and the evidence of fossil plants, has led to the suggested correlation of the red beds of Kansas, Oklahoma, Texas, and New Mexico with the Dunkard series of Ohio and Pennsylvania and with the isolated deposits carrying vertebrate fossils near Danville, Vermillion County, Illinois. Such suggestions of correlation, however, do violence to the probabilities indicated by the stratigraphic position of the beds in which the fossils are found. Though the correlation of widely separated areas must be largely accomplished by fossil evidence, it is becoming increasingly evident to all workers in stratigraphy, as well as paleobiology, that fossils must be regarded and interpreted as once-living things, and the problem of their distribution is inextricably associated with the problem of their living conditions.

The method of evolution is as yet unknown, but all biologists concede the directive influence of environment, once a line is started. In other words, the evolution of life follows and responds to the changed conditions

${ }^{1}$ Ulrich, E. O., Revision of the Paleozoic Systems, Bull. Geol. Soc. Amer., vol. 22, p. 507, I9II. 
in the inorganic environment. If this be true, the beginning of a new geological interval of time is marked by the change in the inorganic world which will lead by slow degrees and a multiplicity of processes to the development or immigration into a definite area, of new forms of life. The interval begins with the establishment of new conditions permitting the establishment of a new life in sufficient abundance to be recognized as constituting a new fauna, faunule, or flora. On the other hand, it is very possible that the establishment of new conditions might be followed by the immediate introduction of a new fauna or flora by immigration. These ideas are in strict consonance with the determination of geological intervals on the principles of diastrophism. If any progressive criteria can be detected and traced which reveal such a change in the inorganic world, then the evidence from life may be better understood and even in some measure anticipated.

The commonly obscure and neglected evidence of climatic change induced by the slow and unimpressive uplift of the continent is the one here used, and, as shown above, the progress of the changed climate is recorded in the line which marks the beginning of red sediments and which cuts obliquely across the stratigraphic column. The persistence of the climatic conditions on the east while they migrated west gives the resultant deposits a wedgeshape (see figs. 5 and 6).

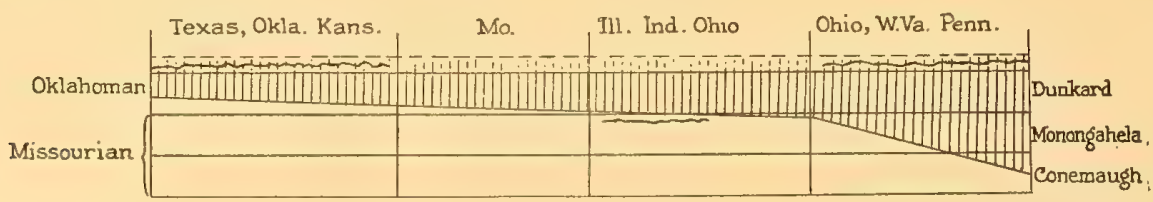

FIG. 7.-Diagram illustrating in a schematic way the relative position of the sediments formed under Permo-Carboniferous conditions. The land was rising from east to west, but there was continuous sedimentation in the eastern region at the western edge of the rising land of Appalachia. As the land rose slowly the red beds spread toward the west, occupying relatively higher positions in the stratigraphic column. It is difficult to illustrate the actual conditions in the diagram, because the "red beds conditions" were advancing, but the wavy lines indicate the surface of the ground relative to these conditions. In Pennsylvania and West Virginia deposition was continuous during the conditions. In Illinois and Indiana deposition had ceased by the time the conditions reached that far west; in Kansas, Oklahoma, and Texas "red-bed conditions" reached the region in time to affect only the uppermost Paleozoic deposits. The upper limit of the red-bed conditions is not known, and so the upper limit of the wedge is indicated by a dotted line.

By all the commonly accepted canons of correlation and by its stratigraphic position the Dunkard, with its typical Permo-Carboniferous flora, fauna, of invertebrates, and single reported vertebrate (Edaphosaurus), is the very approximate equivalent of the Wichita-Clear Fork beds of Texas, but both red beds and Permo-Carboniferous vertebrates are found far below the Dunkard in West Virginia and Pennsylvania. They are, however, well within the limits of "Permo-Carboniferous conditions" in those States. 
The occurrence of Permo-Carboniferous reptiles and amphibians as low as middle Conemaugh is no longer a puzzle; the animals appeared with the environment and migrated with it; they are strictly within the limits of their proper environment wherever they occur.

The sequence in the evidence for the progressive advance of the climatic change which induced the deposition of red beds is broken in two placesat the Cincinnati anticline and at the elevation in Missouri. All efforts to trace the change around these elevations have been only partially successful. The breaks are in part due to the effects of erosion removing all trace of Permo-Carboniferous deposition and in part to the fact that these areas were above the plane of deposition before the migrating climatic change had reached that far west.

One apparent conclusion from the premises here stated is that the PermoCarboniferous vertebrate fauna originated in the eastern part of North America and migrated westward. This the author is not yet entirely ready to accept, but he is strongly impelled toward the conclusion by the facts that the earliest known reptile, Eosauravus, was discovered in the Allegheny series, at Linton, Ohio; that typical Permo-Carboniferous vertebrates appeared in middle Conemaugh time in Pennsylvania and West Virginia; and also that typical pelycosaurs occur in the red beds of Prince Edward Island at a stratigraphic level much lower than those of Oklahoma and Texas.

\section{B. INTERPRETATION OF CONDITIONS IN ALLEGHENY AND LOWER CONEMAUGH TIME.}

As already mentioned, the conditions during pre-Conemaugh Pennsylvanian time were radically different from those in the late Paleozoic. The clastic sediments, coal beds, mode of deposition, etc., are all those of an inclosed basin of singularly monotonous character. Perhaps the best picture that has been given of the various minor basins of the Eastern Province is that by David White: ${ }^{1}$

"Terrestrial Conditions.

"BASE-LeVel Basins.

"The examination of the strata intervening between the coal beds in the great coal fields of the earth and the inspection of the coal show conclusively that nearly everywhere the vegetal matter was deposited and transformed to peat beneath a water surface. Furthermore, in the great majority of the basins, including nearly all the great coal areas, ${ }^{2}$ the coal (peat) was laid down not far from tide-level, marine beds being intercalated at various horizons in the coalbearing series of rocks, and not rarely in the beds immediately overlying the coal itself. In certain basins brackish-water mollusks are found in many of the

\footnotetext{
1 White, David, The Origin of Coal, Bureau of Mines Bull. 38, pp. 52-60, 1913.

2 The very extensive basins of the Fort Union coal in the northern Rocky Mountains region are regarded as fresh-water basins,
} 
shales or limestones, although no distinctly marine faunas have been observed, thus indicating for those basins estuarine waters, which at times may have been completely isolated, though still in close geographic relation to the marine. Brackish-water deposits are present at one or more horizons in most of the extensive coal-bearing formations, whether younger or older, even those which for the most part contain only fresh-water types of life. ${ }^{1}$ Usually, however, the formations are apt also at certain levels to carry distinctly marine faunas. The parallelism of the strata and the frequency of the salt-water invasions show the constant nearness to tide-level, whereas the horizontal extent of the strata indicates the areal extent of the region of deposition. It may therefore be confidently stated that in most of the great coal fields of the world the coal was formed on a nearly level surface at or near sea or lake level.

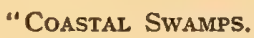

"The enormous horizontal extent of many of the coal groups as indicated by the remnants now found in basins detached as the result of folding and erosion, the demonstrated continuity of some of the individual coal beds over areas some of amazing size, the high degree of parallelism of the beds, and the recognition that the coal beds were laid down beneath a water cover, join in predicating the existence, at the time the coals were being formed, of vast swamps and broad but shallow lagoonal areas subject to subsidence at a generally slow rate. Such coastal or lacustrine swamps, of magnitudes unknown in the world of to-day, appear to have resulted either from the partial submergence of a very mature and broadly extended surface of erosion (peneplain) or from so extensive and so nearly a complete filling of great parts of a basin as to develop, under the action of waves and currents, extremely shallow littoral flats many miles in width. Following periods of deeper subsidence and the deposition of varying thicknesses of other materials, such as clays, sands, and calcareous muds, there was recurrence of proximate filling of the loaded areas of the basin, and occasionally there was slight uplift of the region and consequent withdrawal of the water, so that the level of the subaqueous deposits was so near to the surface of the water cover as again to favor swamp conditions. Sometimes there was sufficient elevation of the region and retreat of the water to bring the old bottom some distance above the water level of the basin; but it is probable that actual elevation to any considerable distance above the sea was exceptional and confined in most cases to the intervals of more marked earth-movements separating many of the geologic formations. Conditions of relative quiescence and of partial exposure must have taken place many times during the deposition of series of strata embracing many coal beds. The periods of such proximation of sea-level and land-level were times of extension of the vascular plant cover to occupy the shallow regions, thus initiating the formation of a new coal bed. If the slope of the exposed land was reduced to a sufficiently low gradient and the rainfall was heavy and well distributed, the swamp conditions would have been extended far inland, the drainage of the water being held back, obstructed, by the most luxuriant and fecund plant growth, so that the state of partial submergence of the land would have been carried for indefinite distances along the nearly flat land surface. At such times the true coast-line was doubtless locally obliterated, except in so far as barrier beaches marked the zone of wave-action and bordered the expanses of open water.

${ }^{1}$ For example consult the stratigraphic sections of the great coal fields of Europe and America. 
"VARYING SUBSIDENCE.

"The thickness, and even the survival, of the peat bed thus begun depended upon several conditions, important among which are contemporaneous subsidence and its rate. It is probable that at times the water body was greatly contracted, receding to deeper and perhaps relatively small areas of the basins; and at other times accelerated regional subsidence caused the reextension of the water-level over the great border zone (littoral). Variation in the rates of subsidence are well established and can be observed even in the present epoch. At times of more rapid depression, when the water became too deep to be interrupted by bars or shoals or when the water-level in the basins was too high and too expansive for subaerial plants to root and grow on the bottom, the water was open to movement and clay and sand were distributed by the waves and currents, or perhaps limestone was formed or calcareous mud was laid down. The effect of these oscillatory movements accompanied by the leveling of the sediments in the basin, as shown by the studies of such extensive areas of continuous horizontal beds as are seen in the Appalachian and the Interior coal fields, seems to have been the production at various times of enormous expanses of broad, shallow pans or lagoons, over the greater part of whose areas the water was not too deep for occupation by the dense and luxuriant vegetation of the time. The examination of the stratigraphy of the Appalachian coal fields and of the Interior basins shows that during the periods of deposition of the coal-bearing groups the filling of the broad, shallow Carboniferous basins nearly kept pace, on the whole, with the subsidence, which obviously varied in rapidity; but the water was never really deep (probably less than 200 feet in the deepest axes, except at rare periods of greatest subsidence), even in the relatively restricted central areas of the basin, far from the varying coast-lines.

"Formation OF BARS AND BarRIERS.

"At other times great areas, probably embracing most of the depositional region, were either above water or so near the surface that sand barriers or bars, possibly in series, and probably more or less irregular in plan, developed far out toward the edge of the submerged shelf, constituting series of lagoonal or landlocked shallows of enormous aggregate extent. Where not too deep or subject to vigorous incursions of the sea these were occupied by the coal-forming vegetation. It is also apparent that in parts of the Appalachian trough large areas of the submerged flats were, for variable periods, isolated from other parts of the basins by differential movements or warpings of the basin, which produced barriers or low arches of great linear extent, these barriers having greater magnitude and permanency than the bars or other lesser barriers just mentioned. Against the bars, barriers, and shoals that appear to have separated the pans or great swamp expanses, the coal beds usually pinch out, though it is frequently observed that, as the result of continued subsidence, or, in cases, as the result of the impounding of water by the dense vegetal growth, which, in a humid climate, raised the ground-water level, the peat bridged many of the shoals and bars.

"It is more than probable that during these periods of coal formation in the broadly extended swamps and lagoons of fresh water the very luxuriant and intricate tangle of peat-producing vegetation, much of it of large size, that occupied the shallow and protected areas, effectually obstructed the penetration to any great distance into the swamps, of salt water, and rendered the peat-forming areas practically nonmarine a few miles back of their seaward margin, though portions of these areas may have been at sea-level. Such obstruction would be 
comparable to the resistance offered by the same vegetation on a nearly flat land, where the water of a heavy rainfall is held back sometimes to a considerable depth by the dense growth and tangle of fallen vegetation, thus extending the swamp conditions far inland. Many coal swamps were in vast deltas.

"Semiaquatic Vascular Plant Growth.

"The examination of the structure, development, and affinities of the principal plant types found associated with the Paleozoic coals points to the conclusion that many of them, especially among the lepidophytes, ${ }^{1}$ grew under conditions characteristic of swamps, a large number of them being adapted to growth in standing water. Pontonie has pointed out that the enlarged bases of the boles of many of the old Sigillariæ and Lepidodendreæ appear precisely comparable to the basal enlargements of the black gum, Jussica, the bald cypress, and many other types growing in water-covered swamps of tropical and warm temperate climates at the present time. The lateral traces or "parichnos" of the leafscars were long ago recognized by Renault as points of air contact with the tracts of lacunose assimilation parenchyma (aerenchyma) in the thick cortices of the trunks. Subsequently Gothan and Pontonie have pointed out that these twin leaf-scars, of ten so conspicuously enlarged on the old trunks, where they sometimes measure nearly a centimeter in length, are in effect lenticels, or breathing surfaces, developed to afford a better air-supply to tissues where the water cover of a swamp deprives the root system of access to the atmosphere. Potonié ${ }^{2}$ has shown also that Sigillaria developed giant "knees," so-called pneumatophores, similar to those developed by the bald cypress when growing in water, and similarly provided with breathing-pores. The height to which some of the trunks of Sigillaria are enlarged justifies the belief they may have grown in some instances in a normal water cover nearly 4 feet in depth. It has also been conclusively shown by Grand 'Eury ${ }^{3}$ that most of the larger types were adapted to survive rapid deposition about their trunks or rhizomes. Evidence that the commonly associated plants also were suited to an aquatic environment is found in the shallow root system of Stigmaria, which extended far out horizontally on or near the surface of the peat in order to avoid the toxic air-exhausted deeper layers; the occurrence of gum-canals in the rootlets of the fern trunk, Psaronius, the hollow interior of the Stigmaria appendages and the absence of root-hairs, distinctly pointing to an aqueous habitat; the presence of air-chambers in the Calamarian roots, and the development of subaerial roots in many types; the presence of mycorrhiza, as described by Osborn, in the roots of Cordaites, indicating a peat substratum for the plant; the air-chambers provided for the flotation of many of the seeds; and the production by many of the lycopods and Calamarian types of two kinds of spores, requiring an aqueous environment in which the two kinds could more certainly come together in a place sufficiently wet to insure fertilization. ${ }^{4}$

${ }^{1}$ See Grand 'Eury, C., Du Basin de La Loire, Compt. Rend., 8th Cong. Geol. Internat., Paris, I90I, pp. 52 I-538; Pontonié, H., Entstehung d. Steinkohle, 5th ed., 1910, p. I73.

${ }^{2}$ Potonié, H., op. cit., pp. 176, 181.

3 Grand 'Eury, C., Sur le caractère paludeen des plantes qui ont formé les combustibles fossiles de tout age, Compt. Rend., vol. 138, I904, p. 666.

- The rapid decrease, almost amounting to disappearance, of the greater number of the very large spored lycopods during Conemaugh time (early Stephanian) was no doubt due to failure of fructification caused by periods of relative drought and reduction of the water-surface, such withdrawal of the water being plainly indicated by the prevalent pseudoxerophytic characters observed in the swamp plants of the period. 
"The prevalence of thick, smooth barks on the trees is another indication of a humid swamp environment.

"Proof that the Stigmaria roots (which are known to have belonged to Sigillaria and several other related lycopodialean types) have in most cases grown in the clays where they are now found beneath the coal or in the clay partings, may generally on close examination be found in $(a)$ the radial position of the interlacing rootlets passing outward from the parent root in all directions and oblique to the bedding; ( $b$ ) the penetration of buried pieces of stem, bark, or other partly decayed roots by the rootlets of later growth, a common occurrence; $(c)$ the fact that the roots extend outward from the base in a normal manner and are "right side up," not having been disturbed or overturned.

"Coal Formation in Brackish or Marine Waters.

"The question arises as to the extent to which coal of the common types may have been laid in brackish or marine waters. This problem is particularly prominent in certain Paleozoic coal fields like those of the Interior basins, in which many coal beds are capped by black shales, generally containing marine shells. The occurrence of Stigmaria roots in place of growth in the underclays of the Carboniferous coal of Missouri, Indiana, and Illinois, even where, as in many places in Missouri, the underclays rest on thin limestones of marine origin, or the occurrence of roots of other kinds beneath the Cretaceous and Tertiary coal, including most of those interbedded in marine formations, must be interpreted as indicating either subaerial conditions previous to an initial stage of inundation of the old soil or a situation at the initial stage of coal formation in which the water was shallow enough to permit rooting and growth of a dense coal-forming vegetation in place. In the latter case it becomes probable that here and there more elevated parts of the bottom, such as shoals, bars, or barrier beaches and broader barriers, the latter often the result of slight warping of the strata of the region, rose above the water-level and excluded the sea from free access during most, if not quite all, of the period of peat deposition. It may further be assumed-and observations of the bedding of the ordinary coal fully support this assumption-that barriers of these kinds were numerous, and that they divided the coal field into smaller areas, which in most cases were very numerous and irregular in form. The latter feature is, of course, normal to the tide-level peneplain surface.

"The physiographic conditions, including the advanced degree of filling of the basins, the perfection of the base-level, the somewhat unequal loading, and the recognized slight warping of the basin floors, all support the hypothesis that during the times of coal formation the areas of broad and unbroken sea expanse were very restricted, being probably confined in most cases to the deeper parts of the basin, ${ }^{1}$ now usually concealed. That, however, the sea probably did in some cases break over the coal-formation swamp is indicated by the intercalation of over-washed muds, silts, or sands, forming partings few of which contain brackish or salt water shells such as Lingula and Orbiculoides. Other overwashes

${ }^{1}$ It is not improbable that such an area of deeper water, largely without appreciable coal deposition, occupies the axis of the Appalachian trough, as defined in Monongahela and Dunkard time, in southwestern Pennsylvania and northern West Virginia. In the first-mentioned State the absence of the coal and the reduction in thickness of the lower coal formations is proven by abundant drillings. Farther south, on the West Virginia side of the valley, especially where the younger Pennsylvanian formations rise to daylight, the changed character of the formations is well recognized. 
originated on the land side and in fresh water. The occurrence of marine mollusks in the roofs of coal beds is far more common than in the partings of the coal. The generally local occurrence and variable character of the partings may be construed as showing that the inroads of the sea were restricted. In this connection it may be noted that the No. 6 coal of Illinois, which extends with unusual regularity of thickness and bedding structure over several counties in the southern part of the State, carries a remarkable persistent argillaceous or slightly sandy and of ten 'pyritic' parting known as the 'blue band,' about 0.75 inch to 3 inches thick, over nearly the whole area.

"The usually rather high ash-content of the coal of the eastern Interior basin, the generally high percentage of sulphur, and the deposition of silica in the organic mass, possibly as the result of precipitation of colloids by the overflow of alkaline waters, appear to the writer to be more or less directly associated with the conception of relative freedom of access of sea or brackish waters, and thus to accord with the occurrence and character of the black carbonaceous roof muds with their marine invertebrate contents which mark the permanent inundation of the peat deposit by the sea. It is not impossible that in these regions of most intimate relation of the level of the peat formation to tide-level, some incursions of salt water, probably local in extent, may have taken place, and that the effects of such immersions are causally connected with the structural characters as well as the chemical qualities of the fuel.

"It is, of course, well known that in many regions peat is in process of formation in salt marshes, that is, in coastal-inlet or estuarine swamps covered by salt water at high tide. It does not, however, seem clear to the writer that coal with so large a percentage of mother of coal, jetlike wood, etc., and with such pure carbonaceous matter, that is, containing so moderate a percentage of ash, as the coal in the Carboniferous of Illinois and Indiana, or that interbedded with marine or brackish-water beds in Wyoming, was laid down in estuaries flooded by seawater at high tides or even at times of ordinary storms. Unfortunately, adequate analyses for the determination of the ash in tidal-marsh peats from many localities seem to be wanting. In this connection it must, however, be remembered that the coal-forming jungle itself, by its great fecundity and profusion of growth, and its correspondingly rapid contribution of refuse and fallen trees, may have constituted an effective barrier into which the salt-water overwash of extraordinary tides or storms would be able to penetrate only a relatively short distance (perhaps a few miles) compared with the great area, often scores of miles in extent, of the arborescent vegetal growth. Such an almost impenetrable vegetal barrier would not only retard or dam the inrush of salt water pending its neutralization, but also would quickly arrest the sediments and, according to the force of the rush, retain them near the periphery of the swamps. It is not improbable that the higher ash-content that is apt to characterize coal beds immediately overlain or interbedded with marine sediments may result from occasional invasions of brackish water into the swamps, the consequent death and decay of the freshwater types and, for short intervals, the deposition of peaty sediments higher in ash, as is characteristic of brackish or salt-water peats at the present day.

"Within the mouths of the estuaries and outlets of the lagoons, as well as at the border of some of the swamps, there must have been transition zones in which the water was at times more or less saline, but just which of the Paleozoic plant types served in these frontier positions, maintaining their stand on the border (brackish) zone of a salt-water habitat, is not at present fully known, 
though it is very probable that some of the types of vegetation were adapted to this habitat. On the other hand, the absence of marine shells from the floor of the coal bed, and the anatomical characters of the fossil plants and condition of life, at the present time, of the descendants and relatives of the coal-forming plant types, show almost conclusively that they were not adapted to live in a habitat of salt-water submergence. Professor Weiss ${ }^{1}$ points out that of the living pteridophytes, only a single fern grows where it is subject to marine exposure. On the other hand, he calls attention to the fact that the fungi found in fossil Lepidodendron wood and the parasites discovered on the Stigmariæ are of fresh-water types, as are also the insect orders to which the eggs found fossil in the bored woods belong. The large size of some of the Calamites, whose trunks sometimes attain a diameter of nearly a foot and a height of 30 feet or more, with the strength and rigidity afforded by thick developments of exogenous wood, should have enabled them, when their bases were embedded in the muds, to offer a relatively strong resistance to such wave-action as may have occasionally been encountered in regions only slightly exposed, but it is not probable that the ancient relatives of our strictly fresh-water horsetail family were able to grow in soil affected by salt water. The large trunks of Sigillaria and Lepidodendron may have offered an effective reinforcement to the calamarian types. Most, possibly all, of the fragments of Carboniferous plants found so rarely in actually marine deposits may well have been brought by drift from terrestrial or freshwater habitats. ${ }^{2}$ On the other hand, it remains most highly probable that the common types of coal of all ages were laid down in fresh or nearly fresh water."

The beds of the Allegheny series show frequent changes of material due to minor but repeated and rapid fluctuations of level, but, as shown by the quotation from David White just given, they maintain on the whole a homogeneity which speaks of widespread and long-continued uniformity in the general aspect of the land and water. The effect of such an environment upon the vertebrate fauna has been discussed by the author in an account of the amphibian fauna of Linton, Ohio. ${ }^{3}$ A small portion of that paper may be repeated here:

\footnotetext{
"The Climatic Environment of Fauna.
}

"The flora of the region around Linton has been reported upon by David White. His list ${ }^{4}$ of the plants of the Freeport group contains no forms differing especially from those of the whole Allegheny series, and all indicate the existence of a 'singularly equable and humid but not tropical or even semitropical climate.' There is no evidence either in the woody growth, foliage, florescence, or fruition of any seasonal changes, either of temperature or of humidity. In other words, the animals lived in a period characterized by the extreme monotony of the climatic environment.

\footnotetext{
"The Organic Environment.
}

"The organic environment of any animal or group of animals may be defined as the group of contacts of that animal with other forms of life. Normally, the

${ }^{1}$ Weiss, F. E., Address to the Botanical Section, British Association for the Advancement of Science, Science, vol. 34, 1911, p. 476.

${ }^{2}$ White, David, Value of Floral Evidence in Marine Strata as Indicative of Nearness of Shores, Bull. Geol. Soc. Amer., vol. 22, I9I I, p. 221.

${ }^{3}$ Case, E. C., The Environment of the Amphibian Fauna at Linton, Ohio, Amer. Jour. Sci., vol. 44, pp. 124-136, 1917.

${ }^{4}$ White, David, Bull. Geol. Soc. Amer., vol. I, p. I54, 1900. 
organic environment comprises both the flora and fauna, but in this instance the animals were not, so far as we can see, influenced by the vegetation more than that they profited by the shade of the umbrageous growths, sought refuge in the interstices of submerged roots, or possibly fed upon some forms of the algæ in the pool. None of these factors would have left any readable record in the morphology of the animals. The list of flora occurring in the shales accompanying the coals of the Freeport group has been cited above.

"The Character of the Contacts within the Fauna.

"The list of known amphibians from Linton as given by Moodie" includes 5I species. The genera are as follows:

Brachydectes. Cercariomorphus.

Cocytinus.

Ctenerpetom.

Diceratosaurus.

Eoserpeton.

\begin{abstract}
Erpetosaurus.
Eurythorax.

Hyphasma.

Ich thycanthus.

Leptophractus.

Macrerpeton.
\end{abstract}

\begin{abstract}
Molgophis. Odonterpeton.

Estocephalus. Pelion.

Phlegethontia. Pleuroptyx.
\end{abstract}

\author{
Ptyonius. \\ Saurerpeton. \\ Sauropleura. \\ Stegops. \\ Thyrsidium. \\ Tuditanus.
}

"If we examine the animals as described and illustrated in Moodie's excellent monograph, we find that they were, one and all, provided with sharp, conical teeth, suitable only for a carnivorous or an insectivorous diet. This eliminates the vegetation of the period from consideration as a possible source, at least as an immediate source, of food, but introduces a most effective element of stress in the competition between the animals themselves, on the one hand to capture prey and on the other to escape the attack of predatory forms.

"The possible sources of food were fishes, the amphibia, and very probably the abundant arthropods, molluscs, and insects, though practically no traces of invertebrates have been found with the remains of the amphibians, except the casts of spirorbis-like forms. While there can be little doubt that some of the amphibians were carrion-eaters and scavengers, the ultimate food-supply must have been the invertebrate fauna of the waters and banks, and the very meagerness of the remains of such a fauna speaks eloquently of the crowded habitat and the eager search for every edible particle. Beyond this the diet was of flesh and the fauna was self-devouring.

"From the description given it seems fairly certain that the amphibian fauna was isolated in a pool of clear water surrounded by a great stretch of swamp. The ordinary factors of environment which influenced the development of a fauna were absent or ineffective, the physiography and the climate were monotonous in the extreme; the vegetation had only an indirect effect. The main stress upon the life was competition within the fauna. This stress became very high with the crowding of the pool, but as the monotonous environment afforded but limited possibilities for the formation of new habits, adoption of new habitats or the assumption of a new group of contacts in any form, it was not relieved by any overspecialization either in structure or habit. A study of the amphibia reveals only a very normal group of animals. They varied in size from ro feet to 6 inches in length, some were squat and sluggish, others lithe and serpentiform, some even so snake-like that they had lost their limbs. Some hid for safety in dark holes and corners, others lurked in the slime, feeding on carrion or the lessactive and well-protected forms; still others flashed through the water in active pursuit of prey and dared give battle in their conscious strength. It was a

${ }^{1}$ Moodie, Roy L., Carnegie Inst. Wash. Pub. 238, p. I8, I9I6. 
fauna whose elements occupied all the possibilities of the pool to preserve their lives and propagate their kind, but there is an almost total lack of bizarre and overspecialized forms, none heavily armored and none with an excessive development of tusk or talon or spine, and none that could be called giants of their kind. There was a full occupation of all the reasonable possibilities of life, but nothing that would indicate an extreme adaptation, either for offense or defense, to limited paths of life such as occur in other places and in other geological formations where the members of the faunas were very perfectly adjusted to each other. There was only the healthy growth induced by competition in a fauna which still retained all the resilience of its juvenile stage.

"Such an assemblage existing under very powerful stress, if even from a single source, was full of possibilities of development; ripe for the rapid and wide radiation in habits and structures long denied them by the monotony of their environment. For the animals in such a pool there were but two possible endings. Either the pool would become choked by the growing vegetation of the surrounding swamp, or in the many fluctuations of the land channels would open whereby the animals could escape into other habitats and encounter a new environment. It was apparently the first of these fates which came to the Linton fauna. It was overcome in its full vigor before the ultimate adjustments of life to life had produced the extreme development of armor and weapons of attack seen in more mature or in senile faunas. Elsewhere in the same region similar faunas were released to expend in morphological advances and various adaptations to new conditions the stored-up stresses of similar periods of isolation."

Studies similar to the one made upon the Linton fauna were made upon the faunæ found at Mazon Creek, Illinois, and at the Joggins quarries in Nova Scotia. While they resulted in similar general conclusions, it was impossible to determine the limits of the habitat and the life conditions so closely. It is sufficient to say that from these three localities have come the great majority of the known amphibian remains from the Pennsylvanian, and all bear witness to the monotony of the environment and the accumulating stresses which only awaited the great change of environment which came with the advent of the red-bed conditions to burst into the great radiation of reptilian and amphibian life of the late Paleozoic.

In the report by Stevenson ${ }^{1}$ on the Carboniferous beds of the Appalachian Basin we have a summary of the conditions during the upper Paleozoic from which parts are quoted:

"The Allegheny is a thin formation, but its variations in thickness are considerable. $* * *$ There seems to be no reason for supposing that the Allegheny becomes thicker southward in Kentucky, and at present there is little ground for supposing that it ever reached much farther south than northern Tennessee.

"The sandstones of the Allegheny contrast greatly with those of the Rockcastle, even with those of the Beaver. They are persistent only as narrow bands, and in any given area are apt to be replaced for considerable distances by sandy or even clayey shale. Along the eastern outcrop from Kentucky northeastwardly into Randolph and Upshur counties of West Virginia the sandstones are very

${ }^{1}$ Stevenson, J. J., Carboniferous of the Appalachian Basin, Bull. Geol. Soc. Amer., vol. I8, p. 150,1907 . 
conspicuous, very coarse, and at times for miles almost continuous from bottom to top of the formation, composing in part Mr. Campbell's Charleston sandstone. Farther north, in the Potomac area, the sandstones are differentiated, broken by beds of shale; yet even there the Butler and Clarion are massive, the former at times pebbly. The sandstones are irregular in Broad Top and the pebbles are few. Within western Pennsylvania the Butler and Freeport sandstones appear to be most nearly persistent, and each of them occasionally shows some pebbles; but they vary greatly in thickness and each of them is often replaced by shale in tracts containing hundreds of square miles. Well records in the deep portion of Ohio and West Virginia usually show more or less sandstone in one or more of the intervals, but many show so little aside from shale that the sandstone must be due merely to local sorting of material. Pebbles are reported only from Wirt County of West Virginia. The great sandstones of the eastern outcrop in West Virginia break within a few miles toward the northwest; thin shales appear, which soon increase in thickness, and the sandstones become unimportant. Along the western outcrop in Ohio, sandstone is most nearly persistent in the Butler and Freeport intervals. Ordinarily fine in grain, the latter shows pebbly streaks in Stark, Carroll, Harrison, Wayne, Tuscarawas, and Muskingum Counties-that is, along the northwestern side; yet in all of these counties not a few sections show only shale. The Clarion (Hecla) sandstone becomes very conspicuous in southern Ohio and is equally so farther south and southwest in Kentucky. It is noteworthy that a conglomerate is present in parts of Kentucky, near the horizon of the Vanport limestone, and that at one locality the ore associated with that limestone is so crowded with quartz pebbles as to be worthless.

"The character and distribution of the sandstones show sufficiently a great advance of the shore-line or a considerable elevation of land at the southwest. The former condition seems the more probable, and the Allegheny deposits can have extended hardly so far in that direction as did those of the Beaver. The shore-line at the east-southeast must have been at only a short distance from the present outcrop, as the strip of sandstone is very narrow. Coarse material could be pushed only a little way in the shallow water of that time. There is much to suggest a similar advance of the shore at the northwest, not only in the unexpected coarseness of the sandstone, but also in distribution of the limestones. The presence and great predominance of sandstone in Kentucky, on the southern and southwestern borders, is equally suggestive of land encroachment in that direction."

The Putnam Hill limestone of Ohio is said by Stevenson to be very fossiliferous and to mark an invasion of the sea from the west; similarly the Black Flint on the Kanawha River, at the same horizon, is said to mark an invasion from the Atlantic in the form of a branching bay.

"The Vanport (ferriferous) limestone marks a still greater inroad of the interior, or Mississippian, sea, reaching in northwest Pennsylvania almost to the New York line. $* * *$ On the Kanawha, in West Virginia, Professor W. B. Rogers found a bed crowded with marine forms at I 40 feet above the black flint, too high for the Vanport horizon, but of interest as proving access to the Atlantic at more than one time during the Allegheny. *** No later important inroad of the sea occurred. The fossiliferous shale over lying the middle Kittanning is found only as far north as central Ohio, while the lower and upper Freeport lime- 
stones, though extending over a great part of the basin at the north, are either nonfossiliferous or contain only fresh-water forms; but south from the Ohio River in Kentucky the upper Freeport limestone carries a characteristic Carboniferous fauna.

"It is wholly probable that the Appalachian and the Indiana-Illinois fields were not united during the Allegheny, though they may have been during the Rockcastle, as they were during the Mississippian."

\section{INTERPRETATION OF CONDITIONS IN CONEMAUGH AND DUNKARD TIME.}

Mr. Stevenson here (page 154) notes the possible occurrence of persistently aggrading streams from the Homewood sandstone stage to the, in places, base of the Lower Freeport:

"Toward the close of the Allegheny a small area in west central West Virginia near the Ohio River received deposits of red mud, more or less calcareous, accompanied often by greenish muds; and, somewhat earlier, similar deposits were made in northeastern Kentucky. This is the beginning of a condition which in gradually enlarging or contracting area was to continue until the close of Carboniferous time, always predominating, however, within a small area in West Virginia and the adjoining part of Ohio.

"In many respects the Conemaugh is but the continuation of the Allegheny; the variations in thickness are, geographically, very similar in both. *** Except in a very narrow strip along the southeasterly border in West Virginia, the Conemaugh sandstones are more irregular than are those of the Allegheny. One generally finds some sandstone of some sort in the sandstone intervals, but shales predominate in by far the greater part of the area. *** Away from the southeastern border, pebbles are extremely rare, except along a narrow rudely eastand-west strip across Indiana, Armstrong, Butler, Lawrence, and Beaver counties of Pennsylvania. This lies many miles south from the northern outcrop and south from the similar strip in the Beaver formation; its variations are such as one finds in the gravels of the upper Ohio River. Many similar valleys filled with standstone during the long subsidence are recognizable in various parts of the area, and occasionally one is found along an anticlinal crest which seems to have been made by subaerial erosion. The sandstones for the most part are indefinite within Ohio, but in Tuscarawas County the Lower Mahoning interval filled with conglomerate and farther south the Buffalo interval is filled with very coarse sandstone at many places. $* * *$

"While in a general way the conditions were similar to those of the Allegheny, showing a gradually contracting area, yet the subsidence was such as to admit sea-water to a much greater space. At the very beginning one finds at somewhat widely separated localities in West Virginia a marine fauna in the Uffington shale which rests directly on the Upper Freeport coal bed, while at most exposures the shale yields only impressions of land plants. Not enough information is available to justify any suggestion respecting the relations of the marine localities, which are confined to the easterly side of the great basin." [It is here suggested by $\mathrm{Mr}$. Stevenson that the Brush Creek limestone is due to an invasion from the east, while the Cambridge limestone is due to an invasion by the Mississippian sea from the west.] 
"With the Ames limestone, inroads of the sea practically ceased. Marine conditions unquestionably were repeated, but never for periods long enough for good development of animal invertebrate life. Limestones appear frequently during the upper half of Conemaugh, several of them widely, though irregularly, distributed, but in no case are they distinctly marine. Some are crowded with minute univalves of undetermined relations; others are associated with carbonaceous shales, filled with fragments of plants and fishes, which point rather to fresh-water conditions.

"The most notable feature of the Conemaugh is the red and green shales, in color resembling those of the Catskill and Shenango, but deeper. The greater development is in west central West Virginia and the adjacent part of Ohio, where at times nearly the whole section is red shale. The greatest geographical expansion was just preceding the deposition of the Ames limestone, when the reds reached southeast nearly to the outcrop and northward to the outcrop in Pennsylvania; but they did not reach into northern Ohio and they are practically wanting east from the line of Chestnut Hill in Pennsylvania. From that time to the end of Conemaugh the area contracted and reds occur in irregular patches. These beds frequently contain nodules of limestone, and are usually fossiliferous. The red shales in some cases mark horizons elsewhere carrying limestone, and they may indicate a marine condition.

"The exceeding shallowness of the water and the long periods of quiet during the Conemaugh are indicated by the coal beds, which, though extremely thin, have great extent. $* * *$

"Toward the close of the Conemaugh the streams bringing in materials had become sluggish, and the deposits, except within limited areas, are fine in grain. The Monongahela began with a long period of exceedingly slow subsidence, during which the Pittsburg coal bed gradually extended across the northern part of the great basin and southward along the east and west sides; but from all sides it became thinner toward the central part of the basin and it is practically wanting in a great part of West Virginia and eastern Ohio, where it occurs only in widely separated patches. The bed may have been almost continuous around the basin. The singular uniformity of conditions and the extreme slowness of movement are shown by the structure of this great bed, persisting in such minute details as partings in tracts of thousands of miles and reappearing even in isolated patches within West Virginia.

"The area of greatest subsidence during the Monongahela did not coincide with that of the earlier formations, as appears abundantly from comparison of sections along several lines. The deepest deposits of Allegheny and Conemaugh were at the north and east; not so in the Monongahela. $* * *$ The greatest subsidence was in north-central West Virginia, whence the thickness decreases in all directions.

"With this change in place of chief subsidence there came clearly a farther contraction of the basin, while elevation at the north led to spreading out of sandstone along much of the northern border. This Pittsburgh sandstone is not present in the eastern localities of Pennsylvania and Maryland, but is persistent in the Chestnut Ridge area of Fayette and Westmoreland Counties, in that State, as well as southward along the eastern outcrop in West Virginia to the last exposure near Charleston, where Doctor White found it 70 feet thick. Evidently it prevailed along the western outcrop in Ohio, for it is present on the northwestern outcrop and also in the central counties along that line, where one is 
again much farther west than in the intervening counties. This sandstone becomes more and more indefinite from all sides toward the interior of the basin. The Sewickley sandstone, underlying the Upper Sewickley coal bed, is fairly persistent on the east side, but is wholly insignificant in Ohio. There, however, an important sandstone overlies the upper Sewickley, not pebbly at the northwest, but coarse and often pebbly in southern Ohio. In Pennsylvania and northern Ohio a more or less persistent sandstone, the Uniontown, overlies the Uniontown coal bed, but ordinarily it is unimportant and many sections show little aside from shale in the interval. In West Virginia, however, a strip of coarse conglomerate, evidently at this horizon, crosses the State from east to west, passing through Lewis, Gilmer, Doddridge, Tyler, and Pleasants Counties and extending into Washington, Morgan, and Athens of Ohio, where it is the 200foot conglomerate of Professor Andrews. It is coarser in West Virginia than in Ohio. The strip is very narrow in the former State and fine-grained rocks replace the coarse material at a short distance north and south; but in Ohio the area is broader, as though additional material had been brought in from that side. This east-and-west line of coarse rock recalls those of the Beaver and Conemaugh in Pennsylvania and may be explained in the same way. The general distribution of coarse material indicates a rising borderland and for the southwest a notable encroachment.

"The limestone [varies] greatly in composition. The Redstone is an impure limestone, yielding a fair lime when burned carefully; the Fishpot, when thin, usually resembles the Redstone, but when thick it is apt to contain some layers of cement rock; the Benwood has several beds of hydraulic limestone, even of cement rock, among its most persistent members, while some of the beds are so impure as to break into small angular fragments after continued exposure; the Uniontown and Waynesburg are rarely more than slightly magnesian.

"Of the numerous limestones, only the Uniontown can be regarded as really persistent; it is present in western Pennsylvania and in Ohio at nearly every locality where its place is shown. The others may be regarded as confined to southwest Pennsylvania, the West Virginia Panhandle, and the immediately adjacent part of Ohio. Their great development is between the Monongahela River at the east and the Ohio River at the west, where in considerable areas limestone and calcareous shale fill more than one-half of the interval between the Redstone and Uniontown coal beds. In all directions from this small area the limestone diminishes quickly and is replaced by shale and sandstone; toward the southwest only some thin streaks remain in West Virginia, and in some portions of that State those streaks seem to be replaced by red shale.

"These limestones are spoken of commonly as merely calcareous muds, and that explanation of their origin was accepted tentatively on a preceding page. But it is insufficient." [Mr. Stevenson regards the origin of the limestones as an unsolved problem.]

"Toward the close of the Monongahela the condition marking the later portion of the Conemaugh was reached once more. In by far the greater part of the area the deposits are fine in grain, and at the end the Waynesburg coal bed was formed, in the northern part of the basin, a bed of curiously multiple structure, which is retained. Like the Pittsburgh, it is wanting in the interior region, but it seems to have reached irregularly southward to a long distance on each side.

"The Washington opens with a plant-bearing shale like that overlying the Pittsburgh, succeeded by a great sandstone, recalling in some respects the sand- 
stones of the Rockcastle. As the area grows smaller in ascending, it becomes necessary for comparison to consider separately the lower and the upper portion of the Washington. $* * *$ The formation thus increases from 160 feet in northern Washington of Pennsylvania to above 480 feet in the northern counties of West Virginia, thus showing a continuance of the Monongahela conditions, with the greatest subsidence in north-central West Virginia.

"The sandstones tell the story of steadily contracting area. The Waynesburg sandstone is persistent in Maryland, in most of Pennsylvania, as well as southward in West Virginia for a long distance. It is massive and at times pebbly, though, like all sandstones of the higher formations, it is sometimes replaced abruptly by shale. In Ohio, along the northwestern border, it is not a coarse sandstone, but farther south it becomes coarser and more prominent, being Professor Andrews's upper sandstone and conglomerate. Thence southeastwardly along the southern border, in Jackson and Putnam of West Virginia, the rock marking this horizon is a coarse sandstone, with quartz pebbles sometimes an inch in diameter. In the interior portion of West Virginia records of oil borings show sandstone persistent in this interval, except in a small area. The Waynesburg is the first sandstone of wide extent in the interior region. No notable sandstone above the Waynesburg appears in Pennsylvania, except that underlying the Upper Washington limestone, which is confined to the borders of the remaining area and disappears southwardly. Below this one finds local sandstones, but they are unimportant. In the southern portion of the basin, on the contrary, the interval above the Washington coal bed is characterized by great sandstones, the Marietta of Doctor White, which appear in their greatest development toward the southwest outcrop, though they are prominent features across West Virginia, extending northward to midway in the State.

"The limestones of the Washington are quite as perplexing as those of the Monongahela and they are confined to a smaller area. *** The limestones of the Washington bear much more resemblance to calcareous muds than do those of the Monongahela, but it is difficult to discover the source whence they were derived. [Mr. Stevenson is inclined to think that these limestones are not marine in origin.]

"During the Washington the crustal movements were sluggish within the basin of deposition. Thin streaks of coal extend over great areas, many of them showing complex structure; but toward the close the movements became more pronounced, and during the early portion of the Greene the deep portion of the basin was confined to Greene County of Pennsylvania and a narrow strip adjoining at the west in West Virginia. ***

"That the area of deposit was contracting rapidly appears also from the sandstone deposits. *** All of these [the Nineveh, Fishcreek, and Gilmore sandstones] are along the middle line of the basin, where during deposition of all formations prior to the Washington the sandstone intervals were usually filled with shale. The sources of supply were much nearer than in earlier periods. But the basin, though rapidly losing in width, still extended for not less than 200 miles in north-northeast to south-southwest direction when the Nineveh limestone was laid down.

"The limestones, except the Nineveh, are of little importance. *** There is no evidence that the sea actually entered the area in which rocks of the Greene formation remain.

"The Red Beds retained their importance apparently to the end within the half dozen interior counties of West Virginia and Ohio, and twice during the 
Monongahela the area showed a very considerable expansion, though in neither case equaling that of the Washington or lower reds of the Conemaugh and in each very much less than that of Pittsburgh reds of the same formation. After the deposition of the Uniontown coal bed their area diminished, and during the Washington and Greene the reds became less and less important, appearing at least in, for the most part, thin and rather widely separated deposits, though occasionally, as in Marshall of West Virginia and northern Greene of Pennsylvania, they attain considerable local importance."

\section{INTERPRETATION OF CONDITIONS IN THE WESTERN PART OF THE EASTERN PROVINCE.}

In eastern Kentucky there are some red and purple shales at the level, approximatetly; of the upper Conemaugh and the lower Monongahela. These are probably the last traces of the more important red beds in West Virginia and Ohio. In western Kentucky, Illinois, and Indiana the red beds do not appear, except for a single local patch just above the coal vII in Illinois. The break in the series of Pennsylvanian deposits caused by the Cincinnati dome makes the exact correlation of the beds in the two parts of the Southern Subprovince impossible, but, as shown in the correlation table, page 48 , the deposits in Illinois and Indiana above the probable Monongahela-Dunkard line are unchanged in character from those below. It is apparent that the uppermost beds preserved were deposited under conditions quite similar to those which prevailed in Pennsylvania and West Virginia during Allegheny and lower Conemaugh time. The advancing climatic change had not reached as far west as these localities when the beds were deposited, although they are at a much higher stratigraphic level than the middle Conemaugh.

The meaning of the vertebrate-bearing bed near Danville, Illinois, and the river-channel sandstones of Merom, Indiana, have been discussed by the author in Publication 207 of the Carnegie Institution, pages 77 to 80; the evidence shown in this paper of the gradual rise of the land from the east and the migration of the environment toward the west strengthens the suggestion made long ago that the Permo-Carboniferous vertebrates found near Danville were embedded in the clays of an excavation of Permo-Carboniferous time in the exposed deposits of Pennsylvanian age. As an alternate hypothesis the absence of the characteristic red deposits of Permo-Carboniferous conditions in this region may well be explained by the lack of any adjacent high land from which such deposits could have been derived and the fact that in this lower land the increase of aridity and lowering of temperature were not sufficiently pronounced to destroy an abundant vegetation the débris from which would have been deposited with the bodies of the animals whose bones are preserved and have reduced any ferric oxide to the ferrous condition, with consequent loss of red color. The extensive 
erosion which must have gone on in this region would have removed a very considerable amount of material, and it is not surprising that any traces of red sediments have been removed and only the deeper material accumulated below the level of ground-water left.

\section{E. INTERPRETATION OF CONDITIONS IN THE PLAINS PROVINCE.}

The condition of the upland in Missouri, which separated the Eastern and Plains Provinces, has been well pictured in the quotation given on page 82 , from Hinds and Greene. The red deposits of the Plain sProvince on its western side are undoubtedly due to climatic conditions very similar to those which prevailed in the eastern province, but their base is at a much higher stratigraphic level than middle Conemaugh. The migration of the climatic change due to the gradual uplift did not make itself felt in the Plains Province until the beginning of Permo-Carboniferous time, well above the Missourian. The difference in depositional conditions in the upper half of the Pennsylvanian in the eastern and western half of the United States has long been recognized. Marine conditions prevailed much longer in the West than in the East and such great swamp areas as characterized the eastern basins were never developed. A glance at the typical Kansas section of the western beds shows the successive series of limestones and shales which occupy the same intervals as the shales and coals of the eastern region. In the East the elevation affected a land of swamps and the climatic change superimposed the deposits of semiarid glacial or subglacial condition upon one of singular equable conditions of temperature and humidity; in the west the elevation obliterated or reduced great areas of epeiric seas and the semiarid and cool conditions came upon the surface and the flats of a rapidly disappearing sea. It is easy to understand why the shales and restricted coals of the western area have yielded so few remains of vertebrate amphibian life in comparison with those of the eastern area.

The source of the material of the red beds of the Plains Province was largely the highlands of the Missouri region, the Ouachita Uplift in Oklahoma, and the Rocky Mountain axis to the west. Schuchert is inclined to think that there must have been a very considerable amount derived from the great Columbia Positive Element of the extreme southwestern part of the United States and the adjacent portion of Mexico. The northern red beds of the Plains Province undoubtedly received a considerable part of their material from the Rocky Mountain axis, but it is possible that some portion came from the northern end of the land exposed in Missouri-Iowa. This suggestion is borne out by the presence of the red deposits near Fort Dodge, Iowa, which, though lower than the typical red beds of the southwest, are at the upper surface of the Missourian. The greater part of the northern portion of the Plains Province is buried under younger deposits and only by inference can the whole of the region be restored. Something 
of this has been attempted by the author in Publication 207 of the Carnegie Institution, page 62 .

It can scarcely be possible that the highlands mentioned failed to share in the general elevation of the continent during Pennsylvanian and PermoCarboniferous times, and though there is no evidence that at any place they reached a height or condition sufficient to produce even incipient glaciation, still the rise was enough to afford an abundance of deposits under red-beds conditions. Indeed, the source of supply seems inadequate to furnish the amount of material that has been accumulated, and this is probably why Schuchert has suggested so remote a source of supply as Columbia.

As has been said, the red beds of the northern part of the Plains Province are so largely buried that the outer borders are not exposed and it is im. possible to say how far they extend from the edge of the Rocky Mountain axis, but that the distance was not excessive is indicated by the discovery in Wyoming of red beds shading into dark-colored shales and limestones to the north and east in Wyoming (Carnegie Inst. Wash. Pub. No. 207, p. 62). What the relation to the land on the eastern side of the northern portion of the Plains Province may have been we have no means of knowing.

In the southern portion of the Plains Province it is evident from the data furnished in the summary description that the red beds material came largely from the south and west and that a considerable body of water lay to the southeast which occasionally spread north and west over portions of north-central Texas for limited periods; the marine conditions seem to have lingered longest in Kansas and perhaps Nebraska.

The origin and source of the red sediments have been the cause of considerable discussion. Two writers in particular have drawn pictures of the Texas-Oklahoma portion of the province which are worth consideration at this point. Beede, ${ }^{1}$ in discussing the origin and color of the deposits in Oklahoma, says:

"In tracing the limestones and shales of the basal Permian beds of Kansas southward into Oklahoma the relationship of the light-colored sediments to the red sandstones, red shales, and red limestones of Oklahoma is clearly revealed. It is shown that some of the heavier ledges of limestone first become sandy along their outcrops in patches a few rods across. Farther south the sandstone areas increase in size until the limestone appears only in local areas in the sandstones and is finally wanting. Traced farther southward, the sandstones become deep red or brown, with local areas of white. The decimation of the fauna sets in as the limestones diminish and the remains of life are not found far beyond the limits of the limestones. The shales become red very much farther north than do the sandstones, and are frequently more deeply colored. Some of the lower limestones become red before they change in to sandstones. The sandstone ledges continue for some distance southward as rather even, uniform beds, but farther on they are found to thicken and thin in a somewhat systematic manner.

1 Beede, J. W., Origin of the Sediments and Coloring Matter of the Red Beds of Oklahoma, Science, vol. Xxxv, pp. 348-350, 1912. 
"Several ledges of sandstone frequently occur in a single section, and where one of these ledges is found thickened the others are apt to be thicker than normal. Likewise they are all found to be thin over certain areas. The regions of thickening and thinning were found to be parallel belts lying north and south at right angles to the major drainage-lines. Two of these belts, together with an intervening region about 8 miles across, were studied. The sandstones thicken at the expense of the shales, sometimes eliminating them. In one instance a thin limestone was traced southwest into one of these zones. A sandstone 20 feet or more beneath the limestone thickens and rises above the limestone and practically unites with the sandstone some distance above it. The limestone seems to die out a few feet from the sandstone, but farther west the latter shrinks to its normal thickness and the limestone is present in its proper position with its usual characteristics.

"In these zones of thickening, which are frequently several miles wide, the sandstones are very irregularly cross-bedded and frequently ripple-marked, while the thickening is uneven. It would seem that these zones are opposite the mouths of streams which brought sediment into the sea, where the coarser materials were carried farther from the shore than opposite the interstream spaces. The irregular thickening of the individual beds may be due to current work, waveaction and heaping into local dunes by the wind, though the action of the last factor is uncertain. The irregular bedding and ripple-marks indicate a sort of littoral or very shoal condition for the deposition of the sandstones and shales.

"As this interesting transition of sediments is traced still farther southward, we find, before reaching the latitude of Shawnee, that the sandstones become more abundant over the whole area, more lenticular, more irregularly crossbedded, and imperfectly lithified. In a single railroad cutting a thick lens of sandstone may fade into a soft sandy clay shale with the same bedding and structure as the stone itself and change back into a sandstone a few rods away. Most of the sandstones are so incoherent when freshly quarried that pieces 2 or 3 inches in diameter crush readily under foot. In many of the wells of the region the water is obtained in 'quicksand.' Most of the shales contain much fine sand and offer little resistance to weathering.

"At their southern limits these red sandstones and shales are found to dovetail into the Permian conglomerates on the southern side of the Arbuckle Mountains, while similar conditions obtain among the higher beds farther west, where similar conglomerates occur on the flanks of the Wichita Mountains. These conglomerates are largely composed of the fragments of the pre-Carboniferous limestones aggregating 8,000 to I0,000 feet in thickness flanking the mountains and at one time covering them. The solution of these limestones produces a red clay wherever the insoluble residue happens to remain undisturbed below the vegetable mold, and the disintegrating limestone conglomerates produce a more or less sandy clay indistinguishable from some of the red sediments. Thus it seems not improbable that much of the material of the red beds in the region studied was derived from these thick limestones.

"Considering all these phenomena, it is apparent that the transition of deposits from the Arbuckle Mountains to the Kansas line is such as would be expected in passing from the mountains out into a shallow epicontinental sea.

"That the solution of limestone produces red residual clays is well known. It is exhibited in the residual soils and clays of the limestone regions of the unglaciated part of the Mississippi Valley, Cuba, southern Europe, and elsewhere. 
The clays thus derived and their coloring matter-the red oxides of iron-are minutely divided and when in suspension settle slowly, but little movement of the water being sufficient to keep them in suspension. This characteristic adapts them to long transportation. The great thickness of the Arbuckle and associated limestones, and their former extent, over thousands of square miles of country where they are now removed or represented only by their upturned edges surrounding the mountains, seem to furnish an ample source of the coloring matter and a considerable amount of clays of these low Oklahoma red beds. The gabbros, red granites, and red porphyries of the Arbuckle-Wichita region also contributed their share of sediment to the red beds.

"From these observations it would appear that the sediments of the lower red beds of Oklahoma were derived largely from the Arbuckle-Wichita Permian land-mass and the coloring matter mainly from the solution of the limestones known to have been removed from it. It also seems probable that the sediments of the region studied, especially those some distance from the mountains, were deposited in very shallow turbulent water, or vast tidal beaches, inimical to life of all kinds, since they are void of fossils or even carbonaceous matter."

Baker, ${ }^{1}$ writing more particularly of the Texas beds, says:

"In Texas, Oklahoma, and Arkansas, early Pennsylvanian marine sedimentation was followed by mountain-making movements in the Ouachita Mountains region of Arkansas and southeastern Oklahoma, and in the Central Mineral (Llano-Burnet) region and the trans-Pecos country (Marathon, Van Horn, and El Paso regions) of Texas. The newly-formed mountains were rapidly eroded and a large part of the mountain region resubmerged beneath the sea in later Pennsylvanian time. In the western trans-Pecos region a later Pennsylvanian limestone nearly a mile in thickness was deposited and in the Marathon region shales and limestone covered the much-eroded, closely folded earlier Pennsylvanian and early Paleozoic rocks. In north-central Texas later Pennsylvanian sedimentation began with sandstones, conglomerates, and shales, and was followed by shales and limestone. The land-derived sediments seem to have been derived from lands to the east and southeast, and for this reason it is believed that the mountains of the Central Mineral region were then more or less continuous with those of southeastern Oklahoma and west-central Arkansas, and perhaps stretched westward to the Marathon Mountains. ***"

"The Pennsylvanian sea of north-central Texas was never very deep and its waters were seldom free from sand and mud brought to it from land areas on the south and southeast. It was only near the close of the period, and then only in the southwestern part of the region, that the sea-waters became fairly clear from land-derived sediments. The coal beds, found in the Strawn and Cisco formations, were probably formed in regions of coastal swamps, the surfaces of which lay very close to sea-level. Comparatively rapid oscillations of sea-level must have sometimes taken place, because we find beds of coal directly overlain by limestones containing abundant marine fossils.

"We may draw for ourselves a fairly vivid picture of later Pennsylvanian times in north-central and west Texas. To the westward lay a great sea with clear waters abundantly teeming with marine animals. On the south and southeast was the land of mountain ranges which came into existence earlier in the Pennsylvanian. Between this land and the western sea was a low foreland and

${ }^{1}$ Baker, C. L., Origin of Texas Red Beds, University of Texas Bull. 29, I9I6. 
shoreline, now submerged beneath a shallow sea, now a marshy land covered by forests of the strange plants of the coal period.

"Near the end of Pennsylvanian time there was another period of mountain formation ${ }^{1}$ in west-central Arkansas and southern Oklahoma. The Cisco formation of north-central Texas was laid down after this period of mountain-building. South and southwest of the Arbuckle and Wichita Mountains of southern Oklahoma the Cisco sediments are red sandstones, conglomerates, and shales, showing by their structures and vertebrate fossils that they were deposited as land sediments by rivers flowing southward and southwestward from the mountains on a flattish plain much like the country along the shore of the present Gulf of Mexico. Farther to the southwest the Cisco sediments become marine shales and limestones, indicating rather clear sea-waters in that direction.

"The beginning of Permian time in north-central Texas was a continuation, without marked interruption, of the later Pennsylvanian. The earliest Permian formation, the Wichita, is very like the $\mathrm{Cisco}$, in the northeast river and shoreline deposits of red color, and in the southwest marine limestones and clays. In trans-Pecos Texas the lower Permian is mainly marine limestone with a smaller amount of shale, and the sediments here have a thickness of about 8,00o feet. Here again, although the exact relations between the Pennsylvanian and the Permian are not yet known, it is probable that there was no great change in conditions between the later Pennsylvanian and the earlier Permian. The clearer and deeper sea, as before, lay to the westward.

"There was a notable change in later Permian time. The upper Permian sediments consist of red clays, and beds of limestone, frequently dolomitic, gypsum, and rock salt. The gypsum and rock salt were deposited from the substances carried in solution by the sea-water upon the drying up of the sea. The upper Permian basin of the Southwest centered somewhere beneath the region of the Llano Estacado. It is very noteworthy that there are no coarse terrigenous sediments in the upper Permian. The land-derived materials are mainly fine clays. When sands occur, they are fine-grained.

"We have in upper Permian time the condition of a nearly or quite landlocked sea gradually shrinking through the drying-up of its waters. The sediments contributed to this sea were fine clays and sands derived partly from the red sediments of the Wichita formation and partly from the maturely-weathered residual soils formed during later Pennsylvanian and earlier Permian times. Transportation of these flocculent clays and fine sands would not remove the thin coating of iron oxide by attrition. Even if it did so remove it, the already highly saline waters would not be likely to dissolve it. And even if they did dissolve the coating, the iron oxide would again be deposited before evaporation of the sea-waters had reached a concentration high enough to deposit the gypsum and salt. But it is most probable that the iron oxide coating was never removed by attrition or solution. Fine sediments derived from residual soils are transported great distances by rivers of the present day without the removal of the red coating.

"It is not necessary to assume that all red residual soils are formed from the weathering of limestones. The Tertiary sediments of the southeast Texas Gulf Coastal Plain are not limestones, yet their residual soils are red.

1 Taff, J. A., Preliminary Report on the Geology of the Arbuckle and Wichita Mountains in Indian Territory and Oklahoma, U. S. Geological Survey, Professional Paper No. 3I, I904. 
"In conclusion, it seems evident that the Texas 'red beds' were originally maturely decomposed red residual soils formed under warm and moist climatic conditions. In the older 'red beds' there is no evidence of arid conditions; in the later Permian 'red beds' the residual soils were transported and deposited in arid basins without loss of their color. It is probable that the true origin of all the 'red beds' in the western interior of North America is from residual soils, or the erosion and redeposition without change of color, of older 'red beds."

Tomlinson $^{1}$ in a study of the origin of red beds concludes that the red color is original and that the sediments are residual soils derived from elevations formed at the close of the Paleozoic. Specifically he suggests the derivation of the Cutler and Dolores sediments of Colorado from the Uncompahgre Plateau and of the red beds of Arizona and New Mexico from high lands in Mexico, Arizona, and southern California. The Rustler limestone and Castile gypsum he suggests may be deposits in the clear water of inclosed basins. These give place to red beds on the edges of the basins in shallower water.

For the northern portion of the Plains Province, Richardson ${ }^{2}$ reaches the same general conclusion as to original color and suggests the origin of the material from the Rocky Mountains, washed into a sea which covered the site of the Black Hills. Two possible areas of supply, the Sioux quartzite area of Algonkian age to the east, and the uplifted Pennsylvanian limestones to the east and southeast, are considered, but not regarded as probable sources. However, these may have supplied much material now deeply buried or removed by erosion.

\section{F. INTERPRETATION OF CONDITIONS IN THE BASIN PROVINCE.}

As is shown in the summary description of the Permo-Carboniferous deposits of the Basin Province, the red beds are confined very largely to the southern portion, occurring in northwestern New Mexico, southwestern and western Colorado, northeastern Arizona, and southeastern and southern Utah; to the north the equivalent horizon is marked by shales, impure limestones, and phosphate-bearing beds. Only in Wyoming do red beds of Permo-Carboniferous age occur in the northern part of the Basin Province The source of the material in the southern portion seems to have been in the elevations now forming the southern ends of the Rocky Mountains, for to the south lay the seas in which were deposited the limestones and shales of the trans-Pecos region in Texas, marine conditions which were apparently continued to the west. As noted above (page I52), Schuchert would place the Kaibab limestone and its equivalents in the Permian or Permo-Carboniferous. If this suggestion should finally be accepted, the only effect upon the argument of this work would be to indicate that the climatic change arrived in the southern portion of the Basin Province at a later date than is here assumed.

\footnotetext{
${ }^{1}$ Tomlinson, C. W., Origin of Red Beds, Jour. Geol., vol. 24, pp. I53 and 283, 19r6.
}

${ }^{2}{ }^{2}$ Richardson, G. B., Upper Red Beds of the Black Hills, Jour. Geol., vol. II, p. 365, 1903. 
In the northern portion of the province the deposits must have come from the adjacent elevations of the Rockies and the Bighorn Mountains. The conditions which produced red beds in the south must have been much the same as those which produced the similar beds of the Plains Province and, as has been shown, the mountain barrier was probably low at the southern end. The reason for the replacement of red beds by phosphatebearing shales and limestones and of semiarid terrestrial conditions by marine conditions farther north is less easily understood.

Blackwelder, ${ }^{1}$ in discussing the deposits of phosphate rock in the northern portion of the Basin Province and of phosphate rock in general, says, after reviewing other theories:

"Nevertheless, we find among the rocks derived from oceanic sediments in many parts of the world, beds several feet thick which are rich in lime-phosphate and extend rather uniformly over thousands of square miles. They contain marine fossils which indicate that they have accumulated upon the sea bottom. It is therefore evident that locally there must be conditions which cause the fixation of the phosphoric acid among the bottom sediments. Some students of these deposits have ascribed them to direct deposition of phosphatic shells, bones, and teeth, and others have made appeal to the agency of mineral springs. Generally they have sought an explanation for the abundance of the phosphorus. As the writer has already shown, however, the quantity of phosphorus dissolved in sea-water is always sufficient to produce in a few thousand years even the thickest known phosphate beds; and hence we need only to account for the special conditions which cause it to be precipitated on the sea floor. There is excellent reason to think that the immediately controlling conditions are chemical or biochemical, but these chemical conditions in turn depend upon physiographic and climatic factors difficult to analyze and estimate. The study of the latter is a task for the geologist.

"In its simpler aspects, the chemistry of the marine deposition of phosphates has been plausibly interpreted by a number of European students of the question, even as far back as I870. The following is a modification of their views, based on modern information: The process and results of bacterial decomposition of organic matter vary according to the conditions as well as the particular class of bacteria that are at work. In air and aerated water, decay is generally complete, resulting in the production of carbon dioxide, water, soluble nitrates, sulphates, phosphates, etc. In the absence of oxygen, however, the anaerobic bacteria somewhat more slowly break down the organic compounds and produce a different series of end-products, of which the most important are various hydrocarbons, nitrogen, ammonia, and hydrogen sulphide, with only so much of the carbonic oxides as the available oxygen in combinations permits. In so far as free oxygen is present in only small quantities, there should be a compromise between the two processes.

"Some of the most obvious characteristics of our marine phosphatic rocks show that they have been associated in origin with the anaerobic phase of bacterial action. Almost invariably they are black in color and, owing to the fact that they contain noteworthy quantities of hydrocarbon oils, tars, and gases, they are

${ }^{1}$ Blackwelder, Eliot, The Geologic Role of Phosphorus, Amer. Jour. Sci,, vol, XLII, p. 29I, I9I6. 
famous for their bad odor. In central Wyoming, phosphate rocks of this kind contain so much oily matter that they are being successfully exploited for petroleum. Although such phosphates contain a few fossils such as fish teeth, brachiopods, and larval gastropods, they are invariably devoid of sessile bottominhabiting organisms, a fact which suggests that the bottom layer of sea-water lacked the oxygen necessary to support life.

"The deficiency of oxygen is, therefore, the controlling chemical condition, for it not only determines that the bacterial decay shall be of the anaerobic type, but also prevents animal scavengers from devouring such organic matter as may fall to the sea bottom, for no animal can be active in an oxygen-free medium. $* * *$

"As was long ago pointed out by Bonnet, under ordinary circumstances all of the products of decay are likely to either remain in solution or escape as gases rather than to be precipitated. Under special conditions, however, most of them remain in solid form and others react with the sediments of the bottom or with materials in solution, in such a way as to form insoluble products. For example, hydrogen sulphide, interacting with the iron compounds, forms the mineral pyrite, which is common in certain types of black shales. In a similar way, phosphoric acid in the presence of ammonia reacts with various substances, and especially lime carbonates, in such a way as to produce phosphatic minerals, of which the commonest is collophanite, said to be hydrous calcium carbophosphate. These changes have been carried out experimentally in the laboratory by several investigators, and the necessary conditions are such as may readily occur on the sea bottom where organic decomposition is in progress. The calcareous shells and fragments lying on the ocean floor thus become phosphatized, and even such organic materials as excretory pellets and pieces of wood are known to have been altered in the same way. Bones, which initially contained about $5^{8}$ per cent tricalcium phosphate, have their organic matter completely replaced by phosphatic minerals, thus raising the ratio to 85 per cent or more. In addition, collophanite is precipitated in concentric layers around particles of sand or any solids, forming round or elliptical granules which resemble the oolitic grains in certain limestones. By the enlargement of these coatings, the granules, shells, teeth, and other objects are cemented into hard nodules or even into continuous beds of phosphatic rock. Such nodules have been dredged up from the bottom of all the oceans in moderate depths, and are not uncommon in certain kinds of marine limestones and shales now on land."

It is shown by Clark ${ }^{1}$ that apatite and calcium phosphate are soluble in carbonated waters and waters containing humic acid. The phosphate is deposited, however, in the presence of calcium carbonate. The reaction $\mathrm{Ca}_{3}\left(\mathrm{PO}_{4}\right)_{2}+{ }_{2} \mathrm{H}_{2} \mathrm{CO}_{3} \rightarrow{ }_{2} \mathrm{CaHPO}_{4}+\mathrm{Ca}\left(\mathrm{HCO}_{3}\right)_{2}$ is reversible, but will only be complete from left to right when all the carbonic acid is neutralized.

As the phosphates of the Basin Province are very largely in the petroleumbearing shale, it is probable that the precipitation of the phosphate was due rather to the real absence of much $\mathrm{CO}_{2}$ than the contact of the dissolved phosphate with limestone. This is a decided contributory proof of the stagnant condition of the sea and the action of anaerobic bacteria.

${ }^{1}$ Clark, F. W., Data of Geochemistry, U. S. Geological Survey Bull. 6I6, p. 519, 1916. 
It does not seem at all probable that the phosphates of the PermoCarboniferous may be referred to accumulations of guano, as the character and, so far as we know, the habits of the animals of the time were not such as to permit such accumulations. Nor does there seem any way in which the phosphate may have accumulated by secondary enrichment to the extent in which they now exist. The suggestion by Blackwelder of original accumulation in a stagnant sea seems by far the most reasonable suggestion. If this be so then we must add to our picture of the surface of the North American continent at the end of the Paleozoic' a great, shallow, stagnant sea covering the greater part of the northern end of the Basin Province within the limits of the United States and becoming gradually shallower toward the north. As shown by the various sections given, the sea was not stagnant through all of its history, for at intervals it received normal limestone deposits and many series of normal shales and sandstones, but at least twice it was reduced to this state. What its borders were to the north we may not know, as the exposed material there is not yet exactly placed in the geological series, and if, as seems probable, the deposits are older than the phosphate beds, the record has been removed by erosion. To the south the sea evidently terminated in shallower water and great flats and shores upon which accumulated the typical red beds.

The difference in the conditions of deposition on the two sides of the northern end of the barrier which separated the Plains and the Basin Provinces is not clear. It would appear that the red sediments of western Wyoming gradually shaded into a sea, possibly a portion of the extension from the Pacific Ocean which at times assumed the character of a relict sea. The gradual elevation which was in progress from north to south, from Alaska to northern California, extended its influence eastward and may have been of large influence in cutting off and confining portions of this sea, converting them at times into inclosed bodies of water which became stagnant.

\section{G. INTERPRETATION OF CONDITIONS IN BRITISH COLUMBIA AND ALASKA.}

In attempting an interpretation of the condition at the close of the Paleozoic in British Columbia and Alaska, it will be well to summarize briefly certain conclusions expressed by Daly ${ }^{1}$ in his memoir on the geology of the forty-ninth parallel. On page 6 he divides the entire cordillera into an Eastern geosynclinal belt and a Western geosynclinal belt. The two overlap in the vicinity of the Columbia River. The eastern belt extends from the summit of the Selkirk Range, just east of the Columbia River, to the Great Plains. The formations are almost entirely sedimentary and are included in one general structure which Daly refers to as the Rocky

${ }^{1}$ Daly, R. A., Geology of the North American Cordillera at the Forty-ninth Parallel, Canadian Geological Survey, Memoir 38, 1912. 
Mountain geosynclinal prism. This prism may be traced from Alaska through the Great Basin to Arizona.

The Western Belt is similarly largely made up of sedimentaries and can be traced from Alaska to southern California.

On page 547 is given a statement of the principles upon which his correlations have been based. Most important of these, for the purposes of this paper, is the statement that many of the beds, unfossiliferous in themselves, have been placed in the geological column by tracing them north or south until they can be connected with fossiliferous beds of known age. The accepted correlations in the summary description of the stratigraphy of British Columbia and portions of Alaska will seem far more reasonable if the reader has the principles set forth by Daly in mind.

In table 35 , page 559 , he places as equal in position (Carboniferous) the following:

$\begin{array}{ccc}\text { Southeastern Alaska: } & \text { Western British Columbia } & \text { Western Geosynclinal Belt: } \\ \text { Ketchikan series. } & \text { and Yukon: } & \text { Pend d'Oreille, Att- } \\ \text { Central Washington: } & \text { Cache Creek group. } & \text { wood, Anarchist, Ho- } \\ \text { Peshastin series, Haw- } & \text { Oregon and northern Cali- } & \text { zomeen, Chilliwack se- } \\ \text { kins formation, Eastern } & \text { fornia: } & \text { ries. } \\ \text { formation. } & \text { Nosoni formation, Mc- Middle California: } \\ & \text { Cloud limestone, Baird } & \text { Robinson formation, } \\ & \text { formation, Bragdon } & \text { Calaveras formation. } \\ & \text { formation. }\end{array}$

In table 36 he states that all these formations were deposited as marine sediments accompanied by vulcanism and are terminated above by unconformities or by contact with bathylithic intrusions. In table 37 he states that the Pennsylvanian in the western belt was a time of marine sedimentation with very widespread vulcanism (general?). Following this there was probably widespread though not energetic movements and local unconformity.

On page 565 it is stated:

"The Western belt is in deep contrast with the Eastern belt and in a large way the two are in reciprocal relations. The area covered by the Western belt has furnished most of the clastic material in the principal geosynclinal of the Eastern belt; the Eastern belt has furnished most of the clastic material composing the principal geosynclinal of the Western belt."

On page 568 is given, in the summary of the geological history, a statement concerning the late Paleozoic:

"At or near the close of the Mississippian period the Western cordilleran belt was certainly submerged, and the Eastern geosynclinal belt was broadly upwarped, without other general deformation of the Rocky Mountain geosynclinal. The main Pacific geosyncline was thus initiated or else deepened, so as to receive a great load of Pennsylvanian sediments. Fossiliferous beds belonging to this period have been found at intervals in the Western belt from the Columbia River to Vancouver Island. So far as they are clastic their materials seem to 
have been derived from the newly emerged Eastern belt. The ancient relation of the two belts was thus reversed, except for local, temporary embayments on the east. This movement was, apparently, felt from Alaska to northern Utah at least; farther south, in the region of the fortieth parallel, the reversal of relations was postponed to the close of the Pennsylvanian period. Otherwise the Eastern and Western belts have respectively behaved as units in the momentous change. The larger part of the Eastern belt was to remain as land through the Permian, Triassic, and most of the Jurassic periods; and even in the later periods to undergo only partial submergence.

"The new relation between the two cordilleran belts was so similar to that which obtained on the line of the fortieth parallel at the close of the Upper Carboniferous period that it is instructive to review King's statement, published on pages 536-537 of the volume on Systematic Geology, Fortieth Parallel Survey:

"After the close of this great conformable Paleozoic deposition widespread mechanical disturbance occurred, by which the land area west of the Nevada Paleozoic shore became depressed, while all the thickest part of the Paleozoic deposits from the Nevada shore eastward to and including the Wasatch rose above the ocean and became a land area. Between the new continent and the old one which went down to the west, there was a complete change of condition. The land became ocean; the ocean became land. ***

" Upon the western side of the new land-mass, the Archaean continent, having gone down, made a new ocean-bottom, and upon this immediately began to accumulate all the disintegration-products of the new land-mass which the westward-draining rivers and the ocean waves were able to deliver. Throughout the Triassic and Jurassic periods the western ocean was accumulating its enormously thick group of conformable sediments upon the Archaean floor, **** until, at the close of the Jurassic age, there had accumulated in the western sea 20,000 feet $* * *$ of Triassic and Jurassic material.'

"During the Pennsylvanian period the main Pacific geosyncline was the scene of heavy sedimentation with accompanying powerful vulcanism. The rock exposures at the forty-ninth parallel do not suffice to show clearly the dynamic events leading to the Triassic, but from Dawson's work in Vancouver Island, as well as on the mainland, it appears that there was local deformation of the Pennsylvanian beds in that part of the cordillera, followed by erosion of the upturned strata, before these were buried beneath Triassic deposits. It is likely that the same crustal movement affected the Forty-ninth Parallel section; and, further, that it is to be correlated with the beginning of the Sierra Nevada downwarp described, as above, by King. How long or how extensive was this temporary return to land conditions in the Western Belt can not be declared. It is known, however, that the Triassic period saw, at the forty-ninth parallel, a resumption of marine sedimentation on the Pacific side of the belt. Argillites, sandstones, and limestones, together with great piles of basic volcanic material were then laid upon the Pennsylvanian formations in this region."

It is apparent from the summary descriptions of the Alaska and British Columbia regions and the conclusions given by Daly that at the latest date in the Paleozoic from which we have sediments preserved the Pacific Coast region, even far south of Alaska, was submerged and probably receiving sediments from the Eastern geosynclinal belt now raised above the level of the sea. It is not so apparent that the northern end of the Eastern belt 
was greatly elevated; indeed, the apparent equivalence of the limestones in the Yukon Territory with those of Alaska seem to indicate that these regions were submerged at the same time, but there is little doubt that the progressive elevation of these lands was from north to south and as little that the Eastern belt was land at least in the Permo-Carboniferous. This elevation was sufficient to furnish much sediment to the west and also to terminate the basins of the Plains and Basin Provinces not far south of the present international boundary. The elevation furnished also the probable route of migration of the Asiatic plants represented by the fern Gigantopteris, which reached as far south as Texas. 



\section{CHAPTER VIII.}

\section{PALEOBOTANICAL EVIDENCE AS TO THE EQUIVALENCE OF THE BEDS IN THE EASTERN AND THE PLAINS PROVINCES.}

As evidence of the climatic conditions and the equivalence of the beds in the two widely separated regions where plant remains occur, the fossil plants are perhaps the most accurate that can be used. The identification of the several genera and species, while not final, has reached a stage where dependence can be placed upon the lists as a whole. David White has given a summary of the plants occurring in the Eastern Province which may be taken as the standard for comparison with the other regions and beds. ${ }^{1}$ His list is as follows:

Plants Recorded from the Conemaugh Formation (Pennsylvanian):

Cheilanthites (Sphenopteris) solidus (Lesq.) D. White.

Cheilanthites obtusilobus (Brogn.) Gopp.

Cheilanthites squamosus (Lesq.) D. White.

Mariopteris sillimanni (Brogn.) D. White.

Mariopteris nervosa (Brogn.) Zeill.

Sphenopteris minutisecta Font. and I. C White.

Sphenopteris (Crossotheca) ophioglossoides Lesq.

Alethopteris serlii (Brogn.) Gopp.

Pecopteris unita Brogn.

Pecopteris villosa Brogn.?
Pecopteris cf. jenneyi D. White.

Pecopteris oreopteridia (Scloth.) Sternb.

Pecopteris miltoni (Artis) Sternb.

Pecopteris polymorpha Brogn.

Pecopteris sp. D. White.

Neuropteris ovata Hoffm.

Neuropteris fimbriata Lesq.

Neuropteris scheuchzeri Hoffm.

Sphenophyllum majus Bronn.

Lycopodites pendulus Lesq.

Sigillaria fissa Lesq.

Lepidocystis vesicularis Lesq.

Cordaicarpon gutbieri (Gein.) Gr. 'Ery.

Plants recorded from the Monongahela formation (Pennsylvanian):

Maripoteris ? spinulosa (Lesq.) D. White.

Alethopteris aquilina (Schloth.) Goepp.

Pecopteris unita Brogn.

Pecopteris villosa Brogn. ?

Pecopteris $c f$. jenneyi D. White.

Pecopteris notata Lesq.

Pecopteris nodosa (Goepp.) Schimp.

Dicksonites pluckeneti (Schloth.).
Neuropteris callosa Lesq.

Neuropteris crenulata Brogn.

Neuropteris grangeri Brogn.

Neuropteris scheuchzeri Hoffm.

Lescuropteris moorii (Lesq.) Schimp.

Aphlebia filiciformis (Guth.) Schimp.

Sigillaria menardi Brogn.

List of fossil plants reported from the Dunkard formation (Permian):

Diplothema pachyderma (Font. and I. C. White) D. White.

Sphenopteris minutisecta Font. and I. C. White.

Sphenopteris (Cymoglossa) breviloba (Font. and I. C. White) D. White.

Sphenopteris (Cymoglossa) formosa (Font. and I. C. White) D. White.

Sphenopteris (Cymoglossa) lobata (Font. and I. C. White) D. White.
Sphenopteris (Cymoglossa) obtusifolia (Font. and I. C. White) D. White.

Sphenopteris lescuriana Meek.

Sphenopteris dentata Font. and I. C. White. Sphenopteris auriculata Font. and I. C. White. Sphenopteris foliosa Font. and I. C. White. Sphenopteris hastata Font. and I. C. White. Sphenopteris acrocarpa Font. and I. C. White. Sphenopteris sp.? Font. and I. C. White. Pecopteris pluckeneti (Schloth.) Sternb.

1 White, David, The Fossil Flora of West Virginia, West Virginia Geological Survey, vol. v (A), part II, pp. 390-453, I9I3. 
Pecopteris pluckeneti var. constricta Font. and I. C. White.

Pecopteris germari (Weiss.) Font. and I. C. White.

Pecopteris germari var. crassinervis Font. and I. C. White.

Pecopteris germari var. cuspidata Font. and I. C. White.

Pecopteris dentata var. crenata Font. and I. C. White.

Pecopteris dentata var. parva Lesq.

Pecopteris pachypteroides Font. and I. C. White.

Pecopteris (Goniopteris) emarginata (Gopp.) D. White.

Pecopteris (Goniopteris) oblonga (Font. and I. C. White) Miller

Pecopteris (Goniopteris) newberriana (Font. and I. C. White) Miller.

Pecopteris (Goniopteris) longifolia (Font. and I. C. White) D. White.

Pecopteris (Goniopteris) elliptica (Font. and I. C. White) D. White

Pecopteris (Goniopteris) sp. ? Font. and I. C. White.

Pecopteris (Goniopteris) arguta (Brogn.).

Pecopteris goniopteroides Font. and I. C. White.

Pecopteris (Goniopteris) elegans (Germ.).

Pecopteris arborescens (Schloth.) Brogn.

Pecopteris arborescens var. integripinna Font. and I. C. White.

Pecopteris pennæformis var, latifolia Font. and I. C. White.

Pecopteris candolleana Brogn.

Pecopteris oreopteridia (Schloth.) Sternb.

Pecopteris rarinervis Font. and I. C. White.

Pecopteris imbricata Font. and I. C. White.

Pecopteris platynervis Font. and I. C. White.

Pecopteris asplenioides Font. and I. C. White.

Pecopteris rotundiloba Font. and I. C. White

Pecopteris microphylla Brogn.

Pecopteris angustipinna Font. and I. C. White.

Pecopteris tenuinervis Font. and I. C. White.

Pecopteris subfalcata Font. and I. C. White.

Pecopteris heeriana Font. and I. C. White.

Pecopteris schimperiana Font. and I. C. White.

Pecopteris lanceolata Font. and I. C. White.

Pecopteris inclinata Font. and I. C. White.

Pecopteris merianopteroides Font. and I. C. White.

Pecopteris rotundifolia Font. and I. C. White.

Pecopteris sp. ? D. White.

Pecopteris ovoides Font, and I. C. White.

Pecopteris latifolia Font. and I. C. White.

Pecopteris pteroides Brogn.

Pecopteris miltoni (Artis) Sternb.

Pecopteris polymorpha Brogn.

Pecopteris elliptica Bunbury.

Pecopteris (Callipteridium) grandifolia (Font. and I. C. White) D. White.

Pecopteris (Callipteridium) oblongifolia (Font. and I. C. White) D. White.

Pecopteris (Callipteridium) odontopteroides (Font. and I. C. White) D. White.

Pecopteris (Callipteridium) unitum (Font. and I. C. White) D. White.

Pecopteris (Callipteridium) dawsonianum (Font. and I. C. White) D. White.
Alethopteris virginiana Font. and I. C. White.

Alethopteris gigas (Gutb.) Gein.

Callipteris conferta (Sternb.) Brogn.

Callipteris lyratifolia (Grand 'Eury) var. coriacea (Font. and I. C. White) D. White.

Callipteries curretiensis Zeill. (Font. and I. C. White) D. White.

Tæniopteris lescuriana Font. and I. C. White.

Tæniopteris newberriana Font. and I. C. White.

Tæniopteris newberriana var. angusta Font: and I. C. White.

Neuropteris ovata Hoffm. (variety).

Neuropteris gibbosa Lesq

Neuropteris planchardi Zeill. var. longifolia (Font. and I. C. White) D. White.

Neuropteris dictyopteroides Font. and I. C. White.

Neuropteris fimbriata Lesq.

Neuropteris cordata Brogn.

Neuropteris auriculata Brogn.

Lescuropteris adiantoides Lesq.

Odontopteris reichiana Gutb.

Odontopteris obtusiloba var. rarinervis Font. and I. C. White.

Odontopteris nervosa Font. and I. C. White.

Odontopteris densifolia Font. and I. C. White.

Caulopteris gigantea Font. and I. C. White.

Caulopteris elliptica Font. and I. C. White.

Aphlebia (Rhacophyllum) lanciatum (Font. and I. C. White) Sellards.

Aphlebia lactuca (Presl.) Sterzel.

Aphlebia (Rhacophyllum) speciosissima (Schimp.) D. White.

Aphlebia (Rhacophyllum) filiciformis var. majus (Font. and I. C. White) D. White.

Equisetites rugosus Schimp.

Equisetites striatus Font. and I. C. White.

Equisetites elongatus Font. and I. C. White.

Calamites suckowi Brogn.

Nematophyllum angustum Font. and I. C. White.

Annularia radiata (Brogn) Sternb.

Annularia stellata (Schloth.) Wood.

Annularia sphenophylloides (Zenk.) Gutb.

Annularia carinata Gutb.

Annularia minuta Brogn.

Sphenophyllum oblongifolium (Germ. and Kauff.) Ung.

Sphenophyllum longifolium (Germ.) Gein and Gutb.

Sphenophyllum thoni Mahr.

Sphenophyllum fontaineanum S. A. Mill.

Sphenophyllum filiculme Lesq.

Sphenophyllum tenuifolium Font. and I. C. White.

Sphenophyllum angustifolium Gutb.

Sphenophyllum densifolium Font. and I. C White.

Sigillaria brardii Brogn.

Sigillaria approximata Font. and I. C. White. Cordaites crassinervis Font. and I. C. White.

Baiera virginiana Font. and I. C. White.

Saportæa salisburioides Font. and I. C. White. Rhabdocarpus oblongatus Font. and I. C. White.

Carpolithes bicarpus Font. and I. C. White.

Carpolithes marginatus Font. and I. C. White. Gulielmites orbicularis Font. and I. C. White. 
An annotated list giving the synonymy and exact location of each species is given on pages 392 to 429 of the same publication. Of this list D. White says:

"The floras of the Conemaugh have had but little study and their differentiation from those of the Monongahela, on the one hand, or from those of the Allegheny on the other, is therefore at present very incomplete. The composition and characteristics of the plant life of the Monongahela are also but little understood, though it is known that the floras contain much that is present in, though not peculiar to, the Dunkard (basal Permian)."

As noted above (page 66), D. White has reported the occurrence of a species of Callipteris, a genus diagnostic of the Permian, recently discovered in the upper half of the Conemaugh.

The best summary of the plants of the Plains Province has been given by David White ${ }^{1}$ in his description of the characters and relationships of the genus Gigantopteris, which he regards as not closely related to any known Paleozoic type:

"Its nearest, though perhaps very distant, relatives are, I believe, to be found in the fossils described by Morris as Pecopteris goepperti, really a Callipteris, from the Permian sandstones near Bielebei in the Urals."

Following are the lists of plants given by White from the beds of Texas, Oklahoma, Kansas, and Colorado. The forms marked with an asterisk (*) are characteristic Permian or Permo-Carboniferous species.

"Preliminary List of the Fossils from the Main Plant Bed (M) [in the breaks of the Little Wichita, 4.5 miles southeast of Fulda] and 'Castle Hollow' (H) near Fulda, Texas:

Diplothema sp. ? M.

Pecopteris arborescens, $\mathrm{H}$.

Pecopteris hemitelioides, $\mathrm{H}, \mathrm{M}$.

Pecopteris densifolia?, H.

Pecopteris tenuinervis, $\mathrm{M}$.

Pecopteris grandifolia, M, H.?

Pecopteris, sp., M.

Aphlebia, sp., $H$.

*Odontopteris neuropteroides, M.

*Odontopteris fischeri? M.

*Gigantopteris americana, $\mathrm{M}, \mathrm{H}$.

Neuropteris cf. lindahli, $\mathrm{H}$.

Neuropteris cordata?, M.

*Tæniopteris multinervis, H, M.

*Tæniopteris abnormis, M.

*Tæniopteris coriacea?, M.

Tæniopteris, new species, $M$.

*Annularia spicata, $\mathrm{H}$.

*Annularia? maxima, $M$.

*Sphenophyllum obovatum, M.

Sphenophyllum?, sp., H.

Sigillaria, sp., M.

*Sigillariostrobus hastatus, $\mathrm{H}$.

Cordaites cf. principalis, M.

*Poacordaites cf. tenuifolius, M.

*Walchia piniformis, M.

*Walchia schneideri?, H.

*Gomphostrobus bifidus, $\mathrm{H}$.

*Gomphostrobus? sp., M.

Aspidiopsis, sp., M.

*Araucarites, new species, M, H.

Carpolithes, sp., $\mathrm{H}$.

Insect wings, $\mathrm{M}$.

Anthracosia, M.

Estheria, M. H.

Ostracods, M. H.

Fish scales, M. H.

"Provisional list of fossil plants from Perry (P) and Eddy (E), Oklahoma:

Diplothema pachyderma, E.

Pecopteris cyathea, $\mathrm{P}$.

*Pecopteris geinitzi, $\mathrm{P}$.

*Callipteris, sp., E.

*Gigantopteris americana, E. P.

*Odontopteris ch. permiensis, E.

Neuropteris, sp., E.

*Tæniopteris multinervis, $\mathrm{P}, \mathrm{E}$.

*Tæniopteris abnormis, $\mathrm{P}$.

*Tæniopteris, sp., E.

1 White, David, The Characters of the Fossil Plant Gigantopteris Schenk and Its Occurrence in North America, Proceedings U. S. National Museum, vol. 4I, p. 493, I9I 5. 
Dolerophyllum?, sp., E.

Equisetites, sp., E.

Annularia stellata, P.

*Sphenophyllum obovatum, E.

*Sphenophyllum $c f$. latifolium, P.

*Sphenophyllum stoukenbergi? P.
Sigillaria, sp. ?, P, E.

*Walchia imbricata? P.

*Walchia $c f$. gracilis, E.

*Araucarites, sp., P, E.

Carpolithes, E."

"List of species provisionally identified from the Permian of Kansas. (R) Wreford limestone, west of Reece; (W) shales near the Winfield formation, northeast of Washington; (B) Wellington formation south of Banner; (C) Wellington formation south of Carlton; (S) Wellington formation east of Salina.

*Schizopteris cf. trichomanoides, W.

Pecopteris unita, W.

*Pecopteris pinnatifida, W.

*Pecopteris $c f$. geinitzi, W.

Pecopteris hemiteloides, W.

Pecopteris bucklandi? W.

Pecopteris polymorpha, W.

*Scolecopteris elegans, C.

*Cladophlebis $c f$. tenuis, C.

*Callipteris conferta, W, C.

*Callipteris subauriculata, S, C, B.

*Callipteris $c f$. curretiensis, C

*Callipteris $c f$. Jutieri, R.

*Callipteris $c f$. goepperti, $\mathrm{R}$.

*Callipteris oxydata, $\mathrm{S}$.

${ }^{*}$ Callipteris whitei, B.

*Callipteris lyratifolia? S.

*Callipteris $c f$. scheibei, B

Odontopteris brardii $W$.

Odontopteris minor, W.

*Glenopteris splendens, B, C.

*Glenopteris lineata, B.

*Glenopteris sterlingi, B, C.

*Glenopteris lobata, C.

Neuropteris auriculara?, W.

Neuropteris odontopteroides, W.

Neuropteris scheuchzeri, var., W.

Neuropteris permiana, W.

*Tæniopteris multinervis, W.

Tæniopteris coriacea, B, C.

Tæniopteris coriacea, var. linearis, B, C.

*Sphenophyllum obovatum, C, B.

*Sphenophyllum $c f$. stoukenbergi, W.

*Sphenophyllum $c f$, thonii, W.

*Sigillariostrobus hastatus, R.

Noeggerathia? new species, B.

Cycadospadix? sp., C.

Cordaites principalis, $\mathrm{R}$.

*Poacordaites linearis? C.

*Walchia piniformis, R.

*Walchia $c f$. filiciformis, R.

*Walchia sp., C

*Voltzia sp. C.

*Ullmannia? sp., C.

*Schützia? cf. anomala, $\mathrm{R}$.

*Araucarites? sp., C.

Rhabdocarpis, new species, $R$.

Carpolithes, sp., S. B."

"Provisional list of plants from Fairplay, Colorado:

[The forms marked $A$ are from the Lacoe collection examined by Lesqueroux and are probably from a somewhat higher horizon than the forms collected by D. White, marked B.]

*Sphenopteris schimperiana?, B.

*Sphenopteris lebachensis Weiss, A.

Sphenopteris dentata F. and I. C. W., A.

*Sphenopteris gutzholdi Gutbier, A.

*Pecopteris pinnatifida Gutbier, B.

Pecopteris fœminæformis (Schlotheim) Zeiller, A.

Pecopteris arborescens (Schlotheim) Brongniart, B.

Pecopteris (Danæites Göppert), sp. B.

*Scolecopteris elegans Gutbier, B.

*Callipteris $c f$. hymenophylloides Weiss, A.

*Callipteris cf. lyratifolia (Göppert), B.

Odontopteris subcrenulata Rost, B.

Neuropteris auriculata Germar, B.

*Calamites kutorgæ? B.

*Sphenophyllum obovatum Sellards, B.

Sigillaria? sp., B.

*Sigillariostrobus hastatus, A. B.

Poacordaites, sp., A.

*Walchia piniformis (Schlotheim), A, B.

*Waichia hypnoides, A, B.

*Walchia gracilis? A.

*Ullmannia, sp., A, B.

*Voltzia, sp., A.

*Araucarites, sp., A, B.

*Gomphostrobus bifidus, B."

"List of plants from the Denver and Rio Grande tunnel below Swissvale, Colorado:

${ }^{*}$ Callipteris sp.

*Psygmophyllum $c f$. cuneifolium.

Odontopteris subcrenulata Rost?

Macrostachya? sp.

*Sigillariostrobus hastatus.

*Walchia $c f$. piniformis.

Walchia $c f$. imbricata.

Rhabdocarpos dyadicus Geinitz?"

\section{Concerning these lists D. White says: ${ }^{1}$}

"Fragmentary and incompletely representative of the several floras as the lists may be, they yet show some interesting aspects of the distribution of the Permian species. Thus, the genus Walchia, unknown in the Permian of the

${ }^{1}$ White, David, The Characters of the Fossil Plant Gigantopteris Schenk and Its Occurrence in North America, Proceedings U. S. National Museum, vol. 4I, page 5 II. 
Appalachian trough, is present at most of the localities, while Callipteris, which is very meagerly represented in eastern North America, is common and highly differentiated in Kansas and Colorado. Gomphostrobus, another type characteristic of the Permian of western Europe and hitherto unknown in North America, is present in Kansas, Colorado, Oklahoma, and Texas. The common type of simple-leafed Taniopteris, diagnostic of the western European lower Permian, is nearly everywhere present, sometimes accompanied by other forms, one of which, with distant, simple nerves, is of distinctly Mesozoic aspect.

"In addition to the many Callipteris and Walchia species just mentioned, the provisional lists from the western Permian include a number of other forms near to, if not identical with, diagnostic Old World Permian types hitherto unknown in this continent. Among these are Schisopteris cf. trichomanoides, Sphenopteris lebachensis, Pecopteris geinitzi, Pecopteris pinnatifida, Cladophlebis? cf. tenuis, Scolecopteris elegans, Odontopteris subcrenulata, Taniopteris abnormis, Annularia spicata, Rhabdocarpos cf. dyadicus.

"It is probable that several cosmopolitan species of Pecopteris and Sphenopteris will be found to have accompanied Taniopteris multinervis from western Europe to eastern China.

"The examination of the materials from the Western Interior and Rocky Mountain basins shows that while the flora is composed mainly of types common to western Europe which have undoubtedly been distributed along essentially the same northeastern Arctic-American route by which the Pennsylvanian floras migrated, it contains also a somewhat unique element unmistakably derived from eastern Asia. The latter includes the Gigantopteris, the peculiar Annularia, and a Taniopteris form, to which should possibly be added the representatives of Araucarites and Neuropteridium. The migration of this land-plant element was very probably by the north Pacific.

"The most important deduction to be drawn from the occurrence of Gigantopteris and its particular associates in North America is the essential continuity of environmental conditions indicated thereby. The vital conditions under which the types lived in Oklahoma and Texas can not have been very far different in their essential respects from those prevailing in the Chinese habitats of the types. Environmental conditions sufficiently uniform to enable these plants to thrive must have attended the route of their land migration. We may therefore conclude that a climatic environment essentially similar extended from China to western North America; that is, that during Gigantopteris time western North America and portions of eastern Asia were probably included in the same climatic province. The mingling of the western European flora with the Chinese elements in Oklahoma and Texas suggests that the latter region may have been on the eastern border of the province.

"Another interesting feature of the western Permian is the presence of fronds possibly identical with Psygmophyllum cuneifolium, Odontopteris permiensis, Odontopteris fischeri, and Sphenophyllum stoukenbergi, species that seem not to have been known outside of the Uralian region, from which they were described. Possibly the remarkable Kansas type described by Sellards ${ }^{1}$ as Glenopteris, which is unlike any European type of its period, and which may be nearest related to the Neuropteris salicifolia of Morris, also is of Uralian or Asiatic descent. The types of Uralian origin also may have reached western North America by the north Pacific route. 
"According to their composition and relations the floras of the younger Carboniferous in Shansi and Sheng-King, or Manchuria, which are either at the latest Pennsylvanian stage or in the early Permian, may with probable safety be assumed to have antedated the early Gondwana glaciation and the existence of the Gangamopteris flora in southern Asia. The question arises, then, whether the floral peculiarities of the Gigantopteris province are due in part to climatic changes leading to refrigeration in India, and whether later the climate of the Gangamopteris province extended over a portion at least of the Gigantopteris province, and if so, whether it did not cover a part of western North America."

And further, on page 513 :

"The very incomplete collections of fossil plants from the Wichita formation in Texas, from its supposedly approximate equivalents in Oklahoma, from the . Chase and Sumner groups in Kansas, and from the great series of undifferentiated 'red beds' in the Rocky Mountain region of southern Colorado, show a mixed flora embracing (I) mainly representatives of the Permian flora of western Europe, and including many types not previously known in North America; (2) a smaller portion peculiar to the Gigantopteris association in south central and southwestern China; and (3) several types apparently identical with or very close to forms hitherto known only in the Permian of the Uralian region.

"The distribution of the floral elements indicates that the western European or cosmopolitan elements of the flora migrated between North America and Europe, presumably by the same general northeastern route as that followed by their Pennsylvanian predecessors, while the distinctly Chinese types must have come to Texas and Oklahoma by the north Pacific (Alaskan) route, by which the related Uralian forms may also have migrated. Since the land migration of the Chinese types could hardly have been accomplished without the aid of essential continuity of environmental conditions, and since it is probable that the Gigantopteris elements lived under climatic conditions mainly similar in both Texas and China, the conclusion appears justified that the climatic province under which they thrived in Asia extended to western North America and that it included the region of not th Pacific migration. The mingling of western European species with Gigantopteris in the southwestern 'red beds' is construed to indicate that this region was probably on the eastern border of the Gigantopteris province."

\section{Sellards ${ }^{2}$ says of the flora of the Wellington shales:}

"The flora of the Wellington differs in toto, so far as species are concerned, from that of the Cherokee shales, and contains only a small proportion of species found in the Douglas formation. Of the species listed from the Wellington only a few have been positively identified with forms found in the Le Roy and Lawrence shales. More than two-thirds of the Wellington species are either identical with or most closely related to species or genera characteristic of the European Permian. The points which seem to have the most importance as bearing on the correlation of the Wellington are the following: (I) The complete absence of species in any way confined to or distinctive of the Coal Measures. (2) The comparatively small number of species originating as early as Upper Coal Measures time.

${ }^{2}$ Sellards, E. H., Fossil Plants of the Upper Paleozoic of Kansas, University of Kansas Geological Survey, volume IX, p. 462, 1908. This is a final paper; preliminary papers were published in the Kansas University Quarterly, volumes 9 and I0, I900-I90I. 
The presence of a few species common to and characteristic of the Permian of Europe. (4) The close relation of the new forms to species characteristic of the European Permian. (5) The distinctly Permian facies of the flora as a whole and its marked advance over the flora of the Upper Coal Measures.

"The advance in the flora consists in the number of species and abundance of individuals of callipterid and tæniopterid ferns and of the new genus Glenopteris, which appears to be related on the one hand to callipterid ferns of Permian types and on the other to the Triassic genera Cycadopteris and Lomatopteris.

"The evidence derived from the fossil plants seems to assure the reference of the Wellington to the true Permian in the European sense.

"The flora of the formations intervening between the Douglas formation and the Wellington shales is much less satisfactorily known. A good deal of interest is attached to the discovery of plants in the Wreford limestone, especially as this formation has been recently regarded as the base of the Permian in Kansas. Nine species have been obtained from this locality, as follows: Baiera sp., Callipteris conferta, Callipteris. sp., Cardiocarpon sp., Carpolithes sp., Cordaites sp., Rhabdocarpos sp., Sigillaria sp., Walchia pinniformis. The collection obtained from this formation is small and comes from a single locality near Reece, Kansas. The association of the flora so far as obtained is with the Wellington rather than with Coal Measures flora. The presence of Walchia in abundance, and of callipterid ferns, along with the small species of seeds common to the Wellington, together with the absence, so far as yet noted, of all of the common Coal Measures species, gives the flora of the Wreford, as developed at Reece, a distinctive Permian facies.

"Coal Measures species, although rare in the collection obtained from the Wreford limestone at the Reece locality, recur in some abundance in the horizon at Washington, regarded by Beede as near the top of the Chase formation."

Other lists of the Kansas plant fossils were given by D. White: ${ }^{1}$

"Elmdale Flora at Onaga,

Pecopteris newberriana F. and I. C. W.

Pecopteris hemitelioides Brongn.

Pecopteris oreopteridia (Schloth.) Brongn.?

Pecopteris $c f$. polymorpha Brongn.

Odontopteris brardii Brongn.

Odontopteris moorii (Lx.) D. W.

Neuropteris plicata Sternb.
Neuropteris auriculata Brongn.?

Neuropteris scheuchzeri Hoffm.

Daubreeia sp.

Asterophyllites equisetiformis (Schloth.) Brongn.

Annularia stellata (Schloth.) Wood.

Radicites capillaceus (L. \& H.) Pot.

"The I3 species from Onaga communicated by Mr. Crevecœur are, as compared with the floras of Lansing and Thayer, obviously of much later age. No species in any way characteristic of the Lower Coal Measures or the Allegheny formation remains. On the other hand, the ferns, either as individual species or as phases of species having wide range, are clearly indicative of a stage at least very high in the Upper Carboniferous (Pennsylvanian). Nearly all the species have been reported from either the Permian of Europe or the Dunkard formation of the United States, though, with the possible exception of Pecopteris newberriana, none are distinctly characteristic of the Permian. Most of the forms present occur in the Dunkard formation, whose flora was fully treated by Professors Fontaine and I. C. White. ${ }^{2}$ Yet the small flora from Onaga contains none of the

${ }^{1}$ White, David, in Adams, Girty and White, Stratigraphy and Paleontology of the Upper Carboniferous Rocks of the Kansas Section, U. S. Geological Survey Bull. 2I I, p. I I 5,1903 .

${ }^{2}$ Second Geological Survey Pennsylvania, Rept. PP, Harrisburg, I880. 
special types or characteristic Permian forms which are present in the Dunkard, and on account of which the greater part of the Dunkard is regarded as Permian.

"It would seem, however, that the Onaga flora should be of later date than the Pittsburgh coal, since the facies presented by several of the species has not yet been seen at so low an horizon. Thus the very large size of the form referred to Pecopteris hemitelioides; the form referred tentatively to $P$. polymorpha, but which seems hardly to differ unless in size from the Dunkard Callipteridium grandifolium; the form identified by Lesquereux from the Dunkard as Neuropteris plicata; ${ }^{1}$ the dilated heteromorphous $N$. scheuchzeri, and perhaps the type here doubtfully listed as $N$. auriculata, all seem to indicate a stage as high as the roof of the Pittsburgh coal, while some of these peculiar phases are present above and are not yet known below the Waynesburg coal, $i . e$. , in the Dunkard. Pecopteris newberriana, which is possibly characteristic of the Dunkard, appears hardly distinguishable from the small phase of $P$. fominceformis, figured by Zeiller, ${ }^{2}$ from the Permo-Carboniferous of France. The normal form of the latter species is reported from the roof of the Pittsburgh coal in the Appalachian trough. It is probable that the apparent absence of many of the Dunkard forms in the lower beds is due entirely to the lack of study of the plants in the strata between the roof of the Pittsburgh coal, which forms the base of the Monongahela formation, and the Waynesburg coal, the top bed of that formation. The absence of lepidophytes from the material in hand constitutes negative, and, under the circumstances, scarcely important proof, since their failure to be present may be due to chance in preservation or collection.

"The evidence presented by this small Onaga flora may, therefore, be construed, so far as it represents the plants of its horizon, as indicating a stage probably within the Monongahela formation of the Appalachian region, or possibly as high as the lowest part of the Dunkard formation, although, with the exception of Pecopteris newberriana, the collection in hand does not contain any species characteristic of the Permian of the Old World, and does not signify a Permian age for the Onaga (Elmdale) beds.

"Marion? (Wellington in Part?) Flora of Dickinson County.

Sphenopteris sp. Sell.

Pecopteris sp. Sell.

Callipteris conferta Sternb.

Callipteris conferta var. obliqua (Goepp.) Weiss.

Callipteris conferta var. lanceolata Weiss.

Callipteris conferta var. vulgaris Weiss.

Callipteris n. sp.

Glenopteris splendens Sell.

Glenopteris simplex Sell.
Glenopteris lineata Sell.

Glenopteris sterlingi Sell.

Glenopteris? lobata Sell.

Odontopteris sp. Sell.

Neuropteris sp. Sell.

Tæniopteris coriacea Goepp.

Tæniopteris coriacea var. lineata Sell.

Tæniopteris newberriana F. and I., C. W.

Sphenophyllum sp. Sell.

"The above list includes only the material published or communicated to the National Museum by Mr. E. H. Sellards, by whom the collection of the State University survey is being elaborated. The specimens are described by him as coming either from the topmost beds of the Marion formation or possibly from the base of the Wellington formation, next above the Marion. The flora is regarded by Mr. Sellards ${ }^{3}$ as of Lower Permian age. I have not had an opportunity to examine the remaining material at the State University, but if the com-

${ }^{1}$ Probably specifically different from the older form, which seems to agree with Sternberg's species and which was placed under the same name by Lesquereux.

2 Fl. foss. bassin houill. et perm. de Brive, I892, pl. IV, fig. 5, 6.

s Trans. Kans. Acad. Sci, vol. XVII, 1900 (I90I), p. 208. 
position of the entire flora proves to be of so young a character as the material described or placed in my hands by Mr. Sellards, his conclusion that the beds are of so late date as the Lower Permian will appear to be fully justified. I am not informed whether any of the gymnospermic species so important in, and so typically characteristic of, the Permian of Europe or Prince Edward Island are present in Kansas. However, such pteridophytic material as has come to me for examination is more nearly typical and characteristic of the Permian than any flora that I have yet seen from another formation in the United States.

"If the plants preliminarily listed above are representative of the plant life of the Upper Marion or the Wellington formation, the flora of these beds is probably of a date fully as late as the earlier of the floras generally referred to the Permian in western Europe. In any event a flora containing these species can hardly be older than the topmost Carboniferous, or transitional from the Upper Carboniferous to the Permian."

\section{A. EVIDENCE OF FOSSIL INSECTS AS TO EQUIVALENCE OF THE PERMO-CARBONIFEROUS BEDS IN THE EASTERN AND THE PLAINS PROVINCES.}

Sellards published the results of his investigations on the insects of the late Paleozoic of Kansas in a series of papers which appeared in the American Journal of Science during the years 1906, I907, and 1909. ${ }^{1}$

The insects described in these papers came from a locality about 3.5 miles southeast of Banner City, Dickinson County, Kansas. The insects occur, with fossil plants, in a fine-grained, laminated limestone associated with a hard concretionary limestone. This limestone belongs in the Wellington horizon and lies directly beneath the Cretaceous in this locality. Including doubtful forms, there are more than 60 species described, with 35 genera, all of which are new. The cockroaches from this locality, described elsewhere, ${ }^{2}$ add Io species and 2 genera, one of which is new. The larger groups represented are:

Odonata, I genus and species.

Plectoptera, Io genera and I3 species. Handlirsch has recognized ephemerids as occurring sparingly in the Permian of Russia.

Megasecoptera, I specimen.

Oryctoblattinidæ, 2 genera.

Protorthoptera, 20 genera, 43 species.

Paleoblattidæ, 2 genera, Io species. The rarity of cockroaches is a peculiarity of this locality.

From the Birmingham shale of the Conemaugh series from near Steubenville and Richmond, Ohio, there were obtained 22 species, belonging to 3 genera, of cockroaches; no other insects were found at this place. Only one of the genera from Birmingham shale has been found at the Kansas locality and not one of the species; the two other genera, however, have

\footnotetext{
${ }^{1}$ Sellards, E. H., Types of Permian Insects, Amer. Jour. Sci. ,vols. xxIrI, xxvII, 1906, I907 1909. Correlation of the Insect-bearing Horizon, in part III, p. I69.

${ }^{2}$ Sellards, E. H., Cockroaches of the Kansas Coal Measures and the Kansas Permian, University of Kansas Geological Survey, vol. IX, p. 50I, 1908.
} 
been found in the Upper Pennsylvanian of Kansas. "The insect remains thus far obtained do not therefore permit a close correlation of the Birmingham shales with the Kansas section. It seems probable, however, that the formation is of a somewhat later age than the Leroy shales with the Kansas Coal Measures." The genus Spiloblattina found in Ohio is also found in the deposits at Fairplay, Colorado, regarded by David White from paleobotanical evidence as of Permian or late Pennsylvanian.

The Cassville shale, at the base of the Dunkard, has afforded numerous specimens from the type locality at Cassville, West Virginia. Scudder recognized 6 species and 5 genera, all cockroaches. Only one genus, Etoblattina, is common to the West Virginia and Kansas localities; no species are common.

Sellards remarks:

"The predominance of the cockroach fauna, together with the absence of such advanced types as true ephemerids, leads to the view that the Cassville locality, although Permian, is much older than the Wellington shales of Kansas. [And further] The insects of the Wellington are on the average of small size as compared with Coal Measure insects. This is particularly noticeable among the cockroaches, all of which are small. This dwarfing of the fauna is of interest as probably indicating unfavorable climatic conditions."

From the Wichita beds of Archer County, Texas, Sellards has described two species of the genus Etoblattina. ${ }^{1}$

${ }^{1}$ Sellards, E. H., Two New Insects from the Permian of Texas, Carnegie Inst. Wash. Pub. No. I46, p. I5I, I9II. 


\section{CHAPTER IX.}

\section{CLIMATOLOGY OF THE LATE PALEOZOIC.}

The suggested causes of climatic change in geologic time which are now considered as most probable are: the atmospheric theory (carbon-dioxide content), the deformation theory, the sun-spot theory, and the solar-radiation theory. The first of these is dismissed by Clements, in his Plant Succession, ${ }^{1}$ with a brevity that seems hardly commensurate with the attention it has received in other quarters. Whatever may have been the local cause of climatic change in any limited locality, it is hardly to be supposed that the change over such a large area as North America in the late Paleozoic was not a part of a world-wide effect produced by some cosmic alteration in which a change in the composition of the atmosphere may well have played a large part. Certainly such a theory is far more applicable in its observable data to a time so remote as the Permo-Carboniferous than any which has to do with the intensity of solar radiation or the number of sun-spots. Chamberlin has already shown the value of this theory and its applicability to the great climatic cycle which culminated in the glaciation at the close of the Paleozoic.

Schuchert, ${ }^{2}$ in a brief critique of the atmospheric theory, states:

"The glacial climates are irregular in their geological appearance, are variable latitudinally, as is seen in the geographic distribution of the tillites between the poles and the equatorial region, and finally, that they appear in geologic time as if suddenly introduced. These differences do not seem to the writer to be conditioned in the main by a greater or smaller amount of carbon dioxide in the atmosphere, for if this gas is so strong a controlling factor, it would seem that at least the glacial climates should not be of such quick development. On the other hand, an enormous amount of carbon dioxide was consumed in the vast limestones and coals of the Cretacic, with no glacial climate as a result; ${ }^{3}$ though it must be admitted that the great limestone and the vaster coal accumulations of the Pennsylvanic were quickly followed by the Permic glaciation. Again, it may be stated that the Pleistocene cold period was preceded in the Miocene and Pliocene by far smaller areas of known accumulations of limestone and coal than during either the Pennsylvanic or Cretacic, and yet a severe glacial climate followed."

${ }^{1}$ Clements, F. E., Plant Succession, Carnegie Inst. Wash. Pub. No. 242, p. 320 , I9I6.

2 Schuchert, Chas., in Elsworth Huntington, The Climatic Factor, Carnegie Inst. Wash. Pub. No. 192, p. 289, I9I4.

${ }^{3}$ Professor Schuchert does not seem to take into consideration the fact that the formation of normal calcium carbonate from the water-soluble acid calcium carbonate liberates an amount of $\mathrm{CO}_{2}$ equal to that which it locks up. The reduction of $\mathrm{CO}_{2}$ in the air occurs in times of land exposure and weathering rather than in times of limestone formation. 
Of the other theories only two may be examined with any hope of a rational application to the late Paleozoic: the effect of volcanic dust in the upper atmosphere in reducing the amount of solar radiation which reached the earth, and the effect of deformation.

The first would have world-wide effect if the calculations of Abbot and Fowle $^{1}$ and Humphreys ${ }^{2}$ are correct and the continuance of the conditions cited by them and quoted in Clements, Plant Succession, pages 322-324, would be sufficient to bring on a glacial period. But, as noted by Clements, "the only evidence of such continuance in geological time would have to be sought in the coincidence, or immediate sequence, of cold or cooled climates with periods of great eruptive activity."

Schuchert ${ }^{3}$ has opposed the sufficiency of this cause, citing the fact that the period of violent volcanic activity at the close of the Mesozoic was not followed by a glacial but only by a "slightly cooled climate." The great Paleozoic and Cenozoic glaciations were not in coincidence with the mountain-making disturbances of those eras. Smaller disturbances localized within periods of the eras produced a slight drop in temperature, but not sufficient to produce glacial conditions.

On the whole Schuchert is inclined to attribute the climatic changes to deformational causes, perhaps accentuated by volcanic dust. He concludes:3

"We may therefore conclude that volcanic dust in the isothermal region of the earth does not appear to be a primary factor in bringing on glacial climates. On the other hand, it can not be denied that such periodically formed blankets against the sun's radiation may have assisted in cooling the climates during some of the periods when the continents were highly emergent."

With this idea Huntington is apparently in agreement. The deformational theory is by far the most obvious and easily applied to the explanation of most of the climatic changes. Evidence has been cited to show that the eastern border of the continent of North America was being elevated in the late Paleozoic, and this movement was but a part of the much greater movement which elevated the Armorican-Variscan chains in Europe and the Appalachian Mountains in North America. As the European portion of this movement was accompanied by vigorous volcanic activity, it is very possible that some late eruptions of great vigor supplied an adequate amount of ash and that, as Clements suggests, the glacial conditions in North America were induced by a coincidence of causes, perhaps in the order of their importance, deformation, volcanic dust, and deficiency of $\mathrm{CO}_{2}$ in the atmosphere.

${ }^{1}$ Abbott, C. G., and F. E. Fowle, Volcanoes and Climate, Smiths. Misc. Coll., vol. 6o, No. 29, I9I3.

${ }^{2}$ Humphreys, W. J., Volcanic Dust and Other Factors in the Production of Climatic Changes, and Their Possible Relation to Ice Ages, Mount Weather Observatory Bull., vol. 6, No. I, I9I3.

3 Loc. cit., p. 287. 
Schuchert has stated, as noted above, that the glacial periods of the past have been somewhat sudden in their onset, but if we give to the expression "glacial periods" the broader meaning which should be given it, implying reduction of temperature with, perhaps, accompanying aridity or semiaridity, it is not so certain that the climatic change was a sudden one. Certainly the change in late Paleozoic time in North America was a slow one, and its slow advent is indicated in the increasing accumulation of red beds, with their suggestion of alternate seasons of drought and humidity. The climatic change from the conditions of the first half of the Pennsylvanian to the Permo-Carboniferous, though slow and marked by local fluctuations, was a very comprehensive one, both in character and the extent of the area involved.

\section{A. CLIMATE OF THE LATE PENNSYLVANIAN.}

The most complete and dependable description of the climate of Pennsylvanian time has been given by David White, ${ }^{1}$ from whose paper the following quotations are taken:

"The extreme range of climate and the strong demarcation of the earth's climatic zones in the present day contrast strongly with the atmospheric conditions that appear to have prevailed during the deposition of most of the extensive coal, even in the high latitudes. Such strongly contrasting secular climatic changes as are shown to have taken place since the deposition of peat began in many of our actual bogs, and as are cited as arguments for possible corresponding variation of climates and vegetal types during the formation of the vastly thicker peat beds from which our coals were made, are not in the slightest degree indicated in the great coal beds of the older formations, and probably never occurred unless in the rarest and most exceptional cases, such as possibly in connection with some of the older Gondwana coal beds of Australia, India, or South Africa. In no part of the world to-day are the genetic conditions of the great ancient coal formations to be found, except locally and on a relatively small scale. Topographically, climatically, and botanically their nearest semblance is to be found in coastal and near-tide-level swamps of the South Atlantic and Gulf States, the great estuarine and lowland swamps of India, and the lagoons and swamps of the Indo-Pacific zone of heavy rainfall."'2

This subject is further considered in connection with a review of the evidence as to the climate attending the great coal formations.

$$
\text { "Climates of the Coal-formation Periods. }
$$

"In the following pages is given a brief outline of evidence and conclusions as to the climates characteristic in general of the periods of the great coal formation, with particular reference to the regions of the coal basins. It will be seen that during the times of deposition of most of the principal coal groups the climate has been characterized by (I) general mildness of temperature, approaching in most cases tropical or subtropical; (2) conspicuous equability or approximation

\footnotetext{
${ }^{1}$ White, David, The Origin of Coal, Bureau of Mines Bull. 38, p. 67, 1913.

${ }^{2}$ Potonié, H., Ein von der Hollandisch-Indischen-Sumatra Expedition entdecktes Tropenmoor. Naturwiss. Wochenschr., Jena, Oct. 20, 1907, pp. 657-666.
} 
to uniformity of climatic conditions, which, with a few exceptions, appear to have lacked cold winters or severe frosts; (3) a generally high humidity, the rainfall being from moderately heavy to very heavy and fairly well distributed, though in many cases there is evidence of the occurrence of dry periods which, however, seem ordinarily to have been comparatively short and not severe; (4) an amazingly wide geographical distribution of these genial and equable climates, which occurred seemingly in almost uniform development simultaneously in the high and in the low altitudes of both the northern and the southern hemispheres. This shows either that the essentially uniform climatic conditions were truly extraordinary in geographic extent, with little regard to modern climatic zones, or that the formation of coal was mainly confined to the areas of the aboveprescribed climatic environment.

"The principal criteria as to climate offered by the fossil plant remains preserved either in the coal or in the enveloping shales and sandstones, and serving as a basis for the conclusions stated above, may be summarized as follows, further particulars being noted in the discussion of the climates of the several most important periods of the coal formation:

" (I) Relative abundance or luxuriance and large size of terrestrial vegetationthat is, rankness of growth, indicating favorable conditions of temperature, humidity, etc.

"(2) Character, condition, and amount of the land-plant material preserved as coal or carbonized in the rocks. The formation of xyloid coal of the ordinary type, composed mainly of subaerial vascular-plant remains indicates humidity. In regions of cool temperature the humidity required for the for mation of peatthe initial state of coal-is moderate; in the warmer climates, where decay is more rapid, not only must the humidity be greatly increased, in order to provide the necessary wetness to retard decomposition, but there must be no long dry seasons of the year for the too great reduction of the water cover. The observations of peat formation at the present day in tropical climates show that in order to permit the decomposition of peat the rainfall must be both very heavy and fairly well distributed through the entire year. ${ }^{1}$

"(3) Great radial distribution, seemingly over the greater part of the earth, and especially over wide ranges of latitude, of identical species and genera in characteristic association, indicating the extension of approximately uniform climatic conditions in these regions. Floras identical, or essentially identical, in remote or detached regions can owe their identity to no other cause than approximate continuity of the environment, whether that continuity is geographic or chronographic. Conversely, the migration of a flora without change is possible only through regions of essentially identical environmental conditions. Illustrations are found in the Carboniferous, Triassic, Jurassic, and lower Cretaceous floras, and even to a remarkable degree in the upper Cretaceous and Tertiary floras.

" 1 Peat formation in the United States is not taking place, according to C. A. Davis (in conversation with the author), in areas of less than 20 inches of rainfall. Practically 25 inches is the lower limit. Failure of peat in certain districts, such as the Piedmont Plateau of the South, would appear to be due in part to the occurrence of long dry seasons; presumably the total rainfall in that region is also insufficient. Peat is forming in Florida and in many tropical and subtropical regions of heavy and welldistributed precipitation. 
"(4) Presence of types known to be adapted to or confined to the warm temperatures or moist climatic conditions of the present day, types that though now extinct once lived in association with other types of ascertained tropical or humid habitats, and types whose descendants or nearest surviving relatives are characteristic of warm climates. Examples are cycadalean types in Carboniferous, Triassic, Jurassic, Cretaceous, and finally in the Oligocene in association, since the Trias, with living tropical and subtropical genera or families; the presence of tree ferns in nearly all periods of coal formation; palms, cinnamon trees, climbing ferns, and many other tropical or subtropical types in the Upper Cretaceous; and the bread-fruit trees, etc., in the lower Tertiary.

"(5) Structures of the plants themselves. Features showing rapidity of growth; that is, abundant rainfall, mild or warm temperatures, etc.--conditions favorable to rapid growth:

"(a) Very large size of the cells, many with thin walls and large intercellular spaces, indicating rapid growth and abundant moisture, noticeable in the woods found in and with most coal.

"(b) Large size of fronds and leaves, indicating conditions favorable to growth and, at present, characteristic of moist tropical habitats.

" $(c)$ Frequency of laciniate, or much-dissected, drooping fronds and pendant branches or twigs seemingly adapted to facilitate the run-off of rain, and protection of the stomata in grooves on the under sides of many leaves, as in the lepidophytes of the Carboniferous. ${ }^{1}$

" $(d)$ Smoothness of bark, which is often thick, pointing toward warm, humid swamps.

"(e) Absence of growth rings in the woods of the older coal formations, showing climatic conditions favorable to practically uninterrupted growth, and the absence of long dry seasons or winter frost. Such absence of rings, when noted in all the associated types, plainly shows the approximation to equability of climate.

" $(f)$ Wide occurrence in the Paleozoic coal fields of heterospory, requiring prevalent swamp conditions; and the occurrence of delayed fertilization and of devices for seed flotation.

" $(g)$ The development of subaerial roots in many of the types.

"(6) A circumstance that may be observed in most coal fields in proof of abundant rainfall at the time of coal formation is the continuity of many coal benches, or strata from one hollow or pan over the intervening shoal or sand bar into the next pan or along the slight gradients of the base-levels, a circumstance impossible except with sufficient rainfall to saturate the vegetal cover and maintain a ground-water table of retarded drainage held by the obstructing vegetation.

"(7) Two other interesting lines of evidence for the warm climate of the Carboniferous are seen, as pointed out by Potonié, ${ }^{2}$ in $(a)$ the development of more flowers and fruits on the lower parts of the stems and branches, as in Ulo-

"1 The interpretation by Davis (in conversation with the author) that the so-called "pseudoxerophytic" feature of swamp and bog plants whose roots extend near the surface and are normal to a wet footing are for the purpose of protection against destructive suffering on occasions of drought when the water-level is usually lowered, and that they are therefore really xerophytic, finds abundant support in the paleobotanical criteria offered by the fossil swamps, as described in an earlier section. The pseudo xerophytic characters appear to indicate probable subjection to occasional times of unusual evaporation.

${ }^{2}$ Potonié, H., Entstehung der Steinkohle, 5th ed., I9ıo, p. I67. 
dendron, Sigillaria, and many Calamariæ, a characteristic of dense tropical forests at the present time, and (b) the presence in many ferns of Aphlebiæ, which to-day are unknown except in tropical types.

\section{"Evenness of Climate in Coal-forming Periods.}

"It must be borne in mind that the climatic conditions here described as having prevailed during the deposition of the groups of coal were not necessarily conditions persisting without change from one period to another; in fact, the characters of the successive floras and their changes are found to indicate the occurrence of many climatic changes, some within the limits of a single period in the geologic record. To these changes in the element of the environment are largely due the important steps in the evolution of the higher plant groups, such as the approximate disappearance of heterospory, and the better protection of the megaspore observed in the cycadofilices of the Carboniferous; the origin of the dicotyledonous leaf, and of delayed germination, the former developed to give a maximum vegetative efficiency in a growing season shortened, as indicated by concurrent evidence by the occurrence of seasons of winter cold, the other to enable the plant to survive several seasons that might be unfavorable for the sprouting and successful start of the plant. The periods of coal formation have, however, been for the most part confined to the long geologic intervals of relatively uniform climate, the principal features of which are outlined later.

"The evidence afforded by the presence of coal in thick and extensive beds in various regions is mostly valuable as indicating that during a long period of time there were no wide variations of either temperature or, especially, humidity.

"But absence of coal or lignite is far from furnishing a certain basis for conclusions as to opposite climatic conditions. The recurrent deposition of coal of large areal extent and thickness postulates a base-level subsidence so adjusted that at various times the necessary close relationship between water-level and the peat-formation surface may be maintained for considerable intervals, to permit peat deposition of the required thickness. The formation of coal (peat) in extensive deposits (always continental) is rare in regions undergoing erosive dissection, on the one hand, and, on the other, it is likely to fail when the subsidence is too rapid or the water-level reaches the region of topographic relief so that the coast is bold. It should be repeated that in successively warmer climates the formation of peat requires not only a heavier rainfall, but also a more even distribution of the same, so as to obviate the occurrence of long dry seasons. Even then its formation is possible only by the great rapidity of plant growth, which exceeds, under favoring circumstances, such as maintenance of the water cover, the rate of rapid decay.

"Pennsylvania ('Upper Carboniferous') Coal Measures."

"Judged by the criteria outlined above, the climate of the principal coalforming intervals of the Pennsylvanian was mild, probably near-tropical or subtropical, generally humid, and equable. The evidence may be outlined in summary form as follows:

"Abundant humidity and condensation are shown by: $(a)$ succulency of the growth, large medullary development, and large intercellular spaces; $(b)$ presence of many hydathodes or water-pores on the leaves (possibly due to an aquatic environment), and abundant lacunose tissue; $(c)$ dissected or laciniate forms of

${ }^{1}$ White, David, loc. cit., page 74. 
the leaves in many species; (d) protection of the stomata in dorsal canals, for example, Sigillaria, as though to prevent flooding, but possibly 'pseudoxerophytic' in origin; (e) great differentiation and vast predominance of pteridophytic forms, including many widely varied heterosporous types to whose prolific fertilization a very wet habitat is most essential; $(f)$ smooth, hard, persistent outer bark; $(g)$ adaptation of nearly all types to fertilization in a rainy habitat, such as protection of pollination and probable flotation of immature seeds; $(h)$ flotation devices possibly peculiar to swamp types; (i) prevalence of great swamps on coastal or inland base-level peneplains, and of great amounts of undecayed vegetal matter remaining either in stratified masses as coal or in the carbonaceous shales and other terrigenous deposits; $(j)$ formation of much xyloid coal, requiring abundant humidity in a climate of mild temperature.

"That the climate was warm is further shown by: $(a)$ the rank, luxuriant growth and large size of the plants, especially of cryptogamous types; (b) the rapid, succulent growth, with large cells; $(c)$ the dense, large undergrowth; $(d)$ the many long climbing or clambering filicoid types, including a considerable number of membranaceous delicate forms; $(e)$ the present tropical habitats of living representatives (e.g., Marratiaceæ and Gleicheniaceæ) nearest related to Carboniferous types, whereas the habitats of the Coal Measures cycad stock are tropical or subtropical; $(f)$ the attainment of gigantic size by the equisetales (so common and highly differentiated in the Coal Measures, and to-day always growing in moist ground), only under warm or mild equable conditions.

"Additional evidence of high importance is found in the absence of growth rings; that is, continuity of growth, indicating absence of winter frosts or of long or severely dry seasons unfavorable for the vegetative process. Equability also may be predicated on the seemingly almost worldwide range of mildness of climate.

"Proof of relative uniformity in climate is based mainly on the extraordinary radial distribution of identical species in all lands, even in high latitudes. Practically entire floras spread over the earth, crossing the equator, seemingly without, so far as noted, experiencing seriously obstructional climatic differences or seasonal changes. Minor differences between the floras of certain regions, for example, the coastal districts and the inland fresh-water basins, and the absence of certain genera or species from one continent or another, have been noted by Gothan ${ }^{1}$ and White, ${ }^{2}$ but as between continents, the comparatively uniform distribution of the floras, although less than is sometimes stated, is a remarkable feature of the period, being most nearly comparable to that of the mid-Jurassic.

"Many identical Westphalian species, including a number characterized by short duration, range across the coal fields of North America and Europe to Persia and China, and a few occur in the Arctic Zone, in South Africa, and in Argentina. It is probable that during "Lower" and "Middle" Coal Measures (Pottsville) time, at least, no zone of torrid heat, as contrasted with polar temperatures, existed in the equatorial regions. On the other hand, it is probable that over most of the earth, at least outside of the polar circles, the temperatures

${ }^{1}$ Gothan, W., Weiteres über floristische Differenzen (Lokalfärbungen) in der europaischen Carbonflora, Zeitschr. Deutsch. geol. Gesell., vol. 6I, No. 7, I909, pp. 313-325; Pflanzen-geographisches aus der paleozoischen Flora, Zeitschr. Deutsch. geol. Gesell., vol. 59, I 907, p. I 50 .

${ }^{2}$ White, David, The Upper Paleozoic Floras, Their Succession and Range, Jour. Geol., vol. 17,1909, p. 328. 
did not vary greatly from region to region, and that they were nowhere torrid, possibly not even fully tropical as a whole. Yet the action of breezes, so well demonstrated by the abundant ripple-marks on the sands of the Coal Measures, is also indicated by the equipment of many seeds and spores with wings (although the latter may have been for gliding), and, more particularly, by the separation of the male and female flowers in most of the flowering plants.

"The action of sunlight may be inferred from the presence of palisade cells to shade the mesophyl, the horizontal attitude of the leaves, and the rapid growth.

"Pottsville Time.

"Of the Pennsylvanian floras, those of the Pottsville and Allegheny time are perhaps widest spread in relative entirety, though the flora of the upper Conemaugh and Monongahela have nearly equal homogeneity in migration. The fact that these floras differ markedly, though the changes are somewhat transitional, especially between the last-named stages - the fact that plant life changed, differentiating, eliminating, and adding types-is probably due not merely to kinetic evolution and exterminative competition; it was undoubtedly due in a large part to changes in the climates as well as in other environmental elements. As to the degree of the climatic change we have little knowledge, but, as is later suggested, they were probably of relatively small magnitude during this interval.

"Allegheny Time.

"As already suggested, it is possible that the maximum uniformity of climate occurred in the upper Pottsville. In the Appalachian trough this was perhaps the period of greatest and most evenly distributed rainfall. In the Rocky Mountains some coal was laid down at this time. The Allegheny, which includes the topmost Westphalian, is marked by the disappearance of many of the climbing and clambering types, whereas the membranaceous and laciniate-leaved forms are much rarer, and the pinnules of the filicoid types are growing larger. Coal formation, which seems to have occurred wherever the adjustment of topography and water-level was favorable, appears, however, to have been general. The woods show no trace whatever of seasonal interruption of growth, and the conclusion that there was no winter frost to cause a periodic stage of arrest of growth seems well founded. That there were, however, times when during certain seasons, possibly exceptional or extraordinary, the water-level was reduced, is nevertheless indicated by the increasing development of pseudoxerophytic characters. As they later become more prominent in the Conemaugh and Permian, they are discussed in connection with the paragraphs referring to those periods.

"Conemaugh Time.

"The Conemaugh (of lower Stephanian age) time witnessed several changes in the floras which may be of climatic cause. Most prominent among these are a rapid decrease, approaching extinction, of the colossal lycopods (Lepidodendreæ), and the rapid development of the group of gigantic tree ferns, such as Psaronius, whose supposed fronds, Pecopteris, became highly varied, very large, and more or less distinctly villous in most species. The evidence therefore points to the occurrence of short, dry seasons. The reduction in the lepidophytes is attributable to occasional unusual failures or disappearance of the water in which their spores must fall in order to insure reproduction of the species. Provision for spells of unusual evaporation may account also for the tremendously thick bark of the Psaronii, with their abundant intracortical ramentum; for the 
protection of the stomata on the leaves of Sigillaria; and for the water-storage tissue in the trunk of Lepidodendron-all swamp types.

"As the Conemaugh is apt to be marked by the deposition of thick red beds, especially in the Appalachian trough, it would at first seem that the characters of the flora only confirm the explanation that redness resulted from aridity. However, in opposition to such a conclusion it must be noted that $(a)$ the flora in the red beds has not been observed to differ very markedly from that in the regions of dark contemporaneous sediments, including coal; (b) the plants, though less varied, are not reduced in size, nor possibly, in number; (c) coal, usually thin, to be sure, occurs in the midst of the red beds of the Conemaugh both in the eastern and the Rocky Mountain regions of America, as well as in Europe, some of the coal being thick; (d) the evidence of seasonal growth ('annual rings') in the Conemaugh woods yet examined is slight, though the rings are a little more distinct than in the Allegheny woods; (e) the great calamitean growth appears unimpeded, though many of the giant species are provided with thick xylem and cortex; $(f)$ the nearest living relatives of the Psaronii, the Marratiaceæ, are now exclusively tropical. In view of these facts it is evident that in the Conemaugh the climate was still mild and practically free from frost, and that the rainfall was at times certainly ample for the production of peat under fresh-water conditions. The absence of coal at other levels may, as in other series, be largely due to lack of proper adjustment of bottom and water-level.

"Granting that the Calamariæ were swamp plants, and that many other types, including the enormous Sigillariæ, were also inhabitants of the marsh, it still remains obvious that aridity was not sufficiently developed to dry up all the swamps. Bearing in mind also the protection of the stomata in the lycopods and Calamariæ, and the villous development of the Pecopteris species, the waterstorage equipment of many of these types, including the tree ferns, the development of waxy covers in some Neuropteris species, and the presence of resin canals and other secretory cells in many of the ferns, cycadofilices, lycopods, and Calamariæ, or, in fact, that the gymnospermous woods were perhaps of kinds less affected by dry seasons, it nevertheless is evident that in general the rainfall was, at certain stages at least, sufficient, even at warm temperatures, to permit coal formation over great areas in nearly every coal field. It seems not improbable that during most of Conemaugh time the total rainfall was distinctly less than in Allegheny time, and it is possible that for brief intervals the climate may have been dry as compared to the latter; but it appears improbable that during ordinary red-bed deposition-say, in the Appalachian trough-the climate even closely approached aridity as that term is employed in reference to present-day conditions. Such intervals must have wrought greater changes, more sweeping extinctions in the flora. From the paleobotanical standpoint the widely current belief that aridity in the actual sense is to be assumed as causally and almost indispensably associated with red-bed deposition is not well founded. The generalization seems to be too broad and too sweepingly applied. In this connection it may be noted that although in the Broad Top and the Potomac basins red beds are almost absent, redness of color extends diagonally downward into the top of the Allegheny, which is still coal-bearing, near the Kentucky-West Virginia line in the Kenova quadrangle. Withal it must not be forgotten that the xerophytic characters are, perhaps, confined to aquatic or swamp plants, and that the protections are exactly those adopted by bog plants of today to insure against exposure to too great loss of water, or to increased toxicity of the substratum resulting from an unusual reduction of the water cover. 
"It may, however, be noted that in the red-bed regions coal formation usually falls off in the thickness if not in the number of the beds; on the other hand, the greatest coal formation of the Conemaugh occurs in general in the districts of least red-bed deposition. We may therefore infer either that the conditions favorable for redness in such cases involve relations of topography, water-level, and epirogenic movement that are less favorable to thick and repeated freshwater peat formation or that a drier state of the land surrounding the swamp not only caused a less rank growth of plant life, but also, by reducing the run-off through jungles formerly tropical in density, permitted smaller burdens of nearly pure vegetal matter to add to that growing in the somewhat reduced swamps. It is possible that in certain regions comparative aridity prevailed for restricted periods during which the floras found a not too distant friendly refuge, from which they returned with the resumption of favorable conditions without too great loss or changes.

"Monongahela Time.

"Monongahela (Upper Stephanian) time is marked in many regions of the earth by conditions approaching in some respects those of the Allegheny. The Appalachian, as well as the contemporary beds in western Europe, eastern Asia (Manchuria and China), and southeastern Africa, are nearly everywhere marked by heavy deposition of coal.

"Among the notable paleobotanical characters of this stage are $(a)$ the presence of a waning group of thick-barked Sigillariæ, probably confined absolutely to swamps; (b) large and abundant Psaronius tree ferns; (c) increasing size of Calamites, reinforced by increased wood development; $(d)$ high differentiation of types of seeds, that is, expansion and differentiation of the seed-bearing habit, as the great spore-bearing types were eliminated, probably in consequence of occasional seasons of unusual dryness; $(e)$ increase of features, possibly xerophyllous, especially in the surviving and new cycadofilices, including Noeggerathia and Dolerophyllum, though most of these are presumably exclusively swamp plants; $(f)$ first appearance of fronds of distinctly cycadaceous aspect (Pterophyllum, Sphenozamites, Plagiozamites). The nearest living relatives of these, as well as of the tree ferns, are tropical or subtropical, and though many of them are accustomed to survive dry seasons, they are characteristic evidence against winter frost. Testimony against winter cold and prolonged seasons of drought, such as would ordinarily prevent peat (coal) formation, especially in a warm climate, is also found in the stage of development of seasonal rings in the wood, the latter being usually slight and sometimes very indistinct, thus showing that the period of interruption or retardation of growth was usually of short duration. Both the survival of warm-climate types and the evidence for relatively short periods unfavorable to growth argue against winter seasons of frost during this time.

"On the whole, the paleobotanical inferences are that during Monongahela time the climate was mild, probably subtropical, and nearly uniform over the greater part of the earth, as shown by the geographic distribution of the types that were able to extend in relative purity of association of identical species ${ }^{1}$ around the world from east to west, and from the latitude of England and Man-

${ }^{1}$ Seven of the eight species described by M. Zalessky (Verh. Russ. K. Min. Ges., vol. 42, I905, pp. 485-508) from the mines at Jantai in Manchuria are also present in western Europe, six of them being present in America also. All of the eleven species reported by R. Zeiller (Ann. des Mines, vol. 4, I 883, pp. 594-598) from Tete on the Zambesi are present in Europe, and nine or ten of them are also found in the Appalachian trough. 
churia on the north to southeastern Africa on the south. Though the total rainfall seems to have been heavy, probably over 50 inches, the climate was seemingly marked by short seasons of dryness, but not of winter frost in any region that has yet furnished fossil plants. The prevalence of great swamps in all areas where littoral deposits are known, and in all continental fresh-water basins, combats the idea of aridity. Though the Monongahela formation contains some red beds in most countries, and though it may have covered short intervals of dryness greater than at other times, it is improbable that desert conditions prevailed in these regions at any time during the period. The existence of well-defined climatic provinces at this time may well be doubted.

\section{"Permian Coal Measures.}

"The rapid changes in the flora of the Permian indicate corresponding climatic changes, and these in turn suggest the differentiation of climatic zones, which at an early stage are reflected in the conspicuous development of at least two great climatic provinces. In northwestern Europe and eastern America, where coals are not rare in the Permian, the climatic changes were less marked than in western America, and particularly in southern Asia and the southern hemisphere, where for a time, presumably in the early Permian, glacial conditions are known to have occurred on a scale far greater than that of Pleistocene glaciation in the northern hemisphere. Consequent to the climatic developments in the broad regions of refrigeration in southern South America, South Africa, India, and Australia, there was developed a peculiar flora, consisting of a limited number of types, which is known as the Gangamopteris (so-called Glossopteris) flora. Although it is practically certain that the extermination of the old mild-climate cosmopolitan plant life from the Gangamopteris floral province was due to climatic rigor, it is not, however, certain that the Gangamopteris flora itself lived under conditions of actual climatic severity, though probably some of its types were able to endure marked seasonal changes. ${ }^{1}$ Hence it does not necessarily follow that the coal beds deposited in the Gangamopteris province during its occupation by this flora were formed in a mean low temperature, though the prevailing climate may have been colder than that in the north at the same time and may have been marked by colder winters. The maintenance of the distinctions between the Gangamopteris and the cosmopolitan floral provinces during the lower Permian was perhaps due to topographic, marine, or other conditions causing isolation."

In connection with this discussion of the climatic conditions of late Paleozoic by David White, it is of interest to quote some remarks from an earlier paper by the same author:

"The Stephanian or Ouralian (including the Gschellian) of Europe dates from the Hercynian uplift. Prior to this movement the sea had reached its maximum extension in the coal fields of the northern hemisphere. The Hercynian thrust caused its practical expulsion from the old synclines of western Europe and the creation, especially to the southward, of new basins, mostly of fresh or brackish water, to which were transferred the scenes of coal-formation. In

${ }^{1}$ See White, David, The Upper Paleozoic Floras, Their Succession and Range, Jour. Geol., vol. I7, p. 320,1909 . 
America the line between the Westphalian and the Stephanian is not yet accurately drawn, the fossil floras being not studied in sufficient detail. In view, however, of the paleobotanical evidence indicative of a point near the AlleghenyConemaugh boundary, I, personally, am inclined to regard the formation of the Mahoning sandstone (conglomeratic), the changed sedimentation of the Conemaugh formation, the probable upwarp of the southern Appalachian region which later resulted in the exclusion of the sea from the northern area also, and the consequent climatic changes, as due to the same great orogenic influence. $* * *$

"It is clear that the new elements of our Stephanian flora are chiefly, at least, of European origin, the plant life there having been directly influenced by the important physical changes to which it was immediately subjected. The various exotic types migrated to North America, probably, along or near the general route traversed by their Westphalian predecessors. Also, since the Stephanian flora of the American basins seems to afford no evidence of a rapid or strongly pronounced climatic alteration, it becomes fairly probable that the more abrupt plant changes described in western Europe were induced chiefly by the sweeping orogenic effects of the Hercynian movement, rather than by a great climatic change of world-wide extent. This does not, however, preclude a moderate but far-reaching modification of climate', in which changes in the atmospheric composition may have played a subtle if not important part. It seems hardly possible that the tremendous amounts of carbon then being stored away in the coal fields as the result of plant extraction from the air could have failed to produce some effect on the atmospheric content of $\mathrm{CO}_{2}$. $* * *$

"The coming of the Permian is characterized not only by orogenic movements in the eastern hemisphere, but also by indications of increasing climatic differences. The first paleobotanical effect of these is the extinction of nearly all characteristic Carboniferous types, except in Pecopteris, Cordaites, and Neuropteris, the latter, however, disappearing nearly completely by the close of the Autunian or lower stage. They are replaced by varied forms of Callipteris, the lingulate Odontopteris, and the ribbon-like Taniopteris, together with expanding gymnospermous types, such as Walchia, Dicranophyllum, Doleropteris, Psygmophyllum, and Ginkgophyllum. Later, in the Saxonian, or Middle Permian, Voltzia, with the thickleaved Equisetites, appears, while more of the older types go out; and in the Thuringian, or Zechstein (Upper Permian), Rhipidopsis, Araucarites, Gomphostrobus, Voltzia, and Ullmannia become the characteristic genera, while Pecopteris, dominant in the Stephanian, has nearly vanished. Though lacking the abundant Cycad and Cladophlebis-Asterocarpus elements, the Upper Permian is in many respects transitional to the older Mesozoic flora. ***"

“' Permo-Carboniferous Climates.'

"Climate of the Carboniferous. - The climate of the Pennsylvanian ("Upper Carboniferous') as viewed in perspective was mild and relatively humid, and, above all, equable over the greater part of the earth. It was moderate in temperature, not tropical, possibly not even subtropical, but, during the Westphalian at least, always and everywhere equable. It was truly temperate. The criteria which may be interpreted in support of this generally accepted proposition include:

"I. The tremendous size and great height of the types, and their rank foliar development, indicating favorable conditions of environment and vigorous nutrition. 
"2. The succulent nature of many of the forms, the large size of the vessels and cells, and the relatively great proportion of soft tissue, all indicating rapidity of growth in a moist, mild climate.

"3. Spongy leaves suggestive of a moist atmosphere, and abundant and large intercellular spaces, as in the lycopods, pointing to rapid moisture-loss; also water-pores for disposal of excess of moisture.

"4. Stomata placed in grooves, as in the lycopods, as if to prevent obstruction by falling rain.

"5. Absence of annual rings in the woods; hence absence of marked seasonal changes.

"6. The analogies of the present day show [that] aerial roots, so prominent in many of the Carboniferous types, are characteristic of moist and tropical climates; that the nutrition- $i$. $e_{\text {. }}$, the decomposition of $\mathrm{CO}_{2}$-is most rapid and the consequent growth also greatest and most rapid where the light is not too strong; that the ferns and lycopods, so abundant in the Paleozoic, usually avoid bright glare. The same types are able to withstand larger amounts of $\mathrm{CO}_{2}$ with benefit to themselves.

" 7 . The nearest living relatives of the Paleozoic vascular cryptogams reach their greatest size in humid and mild or warm climates. The successors of the marratiaceous and gymnospermous types are now mostly confined to tropical or subtropical regions. The cycadalean stock, now characteristic of the same zones, was actually present in the upper Coal Measures.

"8. The formation of great amounts of coal indicates a rank growth, but in a temperature not so warm as to promote decay beyond the limit of rainfall protection.

"9. Living nearest representatives of Paleozoic fishes now inhabit the estuaries of warm countries; while the nearest relatives of the Carboniferous insects are now found in mild and moist habitats.

"I0. The most forcible argument, after all, for an equable and uniform climate lies in the extraordinary geographical distribution of the floras in relative unity over the face of the earth. Humidity must naturally have attended such equability, extending, without distinct terrestrial climatic zones, possibly completely into the polar regions.

"Some of the criteria above mentioned are susceptible of different interpretations; but taken collectively they appear to admit of but one conclusion. Whether or not we admit that climatic changes may be caused by reasonable or practicable changes in the amount of carbonic-acid gas in the air, it is certain that in geological times the vegetation of the earth must have been more or less influenced by the constitution of the atmosphere from which the plant derives so important a part of its real food. ***

"As has already been indicated, the Westphalian probably witnessed the greatest extension of uniformity and equability of climate over the earth. In the Stephanian the flora is hardly so homogeneous, though the world-climate appears still to have been so equable as to allow free migration of the larger part of the flora from a moderate latitude on one side of the equator to the opposite without encountering seriously obstructive seasonal changes. In the Permian the regional distinctions between the floras are much clearer; and presently climatic zones, and consequently botanical provinces, are recognized. Yet, about the North Atlantic the climate of the Lower Permian was still relatively uniform, so that moderately free migration of the floras without the development, so far 
as we know, of pronounced annual rings, took place in the Autunian of France, the Permian of Prince Edward Island, the Dunkard of southwestern Pennsylvanian, the Chase of Kansas, and the Wichita of Texas."

David White cites the fact that the plants of the Red Beds are not essentially different from those of the gray shales and the limestone beds in Pennsylvania and West Virginia and questions whether the red color means anything in particular as to the aridity of the climate. He says:

"It is probable that there was aridity in certain regions and during certain intervals of the Permian; but there was evidently enough moisture to produce most extensive glaciation, and, later, to promote the formation of coals over broad areas in the great fresh-water Gondwana series laid down on the continents of South America, Africa, and Asia."

It is well to recall here a note to David White's discussion of the physiography of the coal basin:

"The rapid decrease, almost amounting to disappearance, ${ }^{1}$ of the great number of the very large spored lycopods during Conemaugh time (early Stephanian) was no doubt due to failure of fructification caused by periods of relative drought and reduction of the water-surface, such withdrawal of the water being plainly indicated by the prevalent pseudoxerophytic characters observed in the swamp plants of the period."

\section{B. CLIMATE OF THE PERMO-CARBONIFEROUS.}

The presence of the red beds across the continent, of the Roxbury tillite, and the New Glasgow conglomerate are all inorganic evidence of a most decided and extensive alteration in climate. Even as far west and south as Oklahoma there is some suggestion of a possible decrease in temperature sufficient to form ice of at least local extent.

Taff $^{2}$ in 1909 reported the presence of a bowlder bed in the Caney shale in the Wichita Mountains, Oklahoma, in which the individual bowlders bear grooves and striæ which he attributed to ice action and the accumulation of the bowlders to floating ice. Ulrich, ${ }^{3}$ in I9II, stated his concurrence in this view. "No other competent means of their transportation than icepresumably heavy shore ice-has been suggested."

This region was visited by Woodworth later, and he also expressed his concurrence with Taff's view, that the bowlders and smaller stones of the Caney shale have been transported by some sort of ice action:

"Floating ice is naturally suggested as the probable agency, notwithstanding that to have pan-ice at sea-level demands a greater degree of cold in this latitude

${ }^{1}$ White, David, Origin of Coal, Bureau of Mines Bull. 38 , note $b$, p. 56, I9I3.

2 Taff, J. A., Ice-borne Boulder Deposits in Mid-Carboniferous Marine Shales, Bull. Geol. Soc. Amer., vol. 20, p. 701, I909.

${ }^{3}$ Ulrich, E. O., Revision of the Paleozoic Systems, Bull. Geol. Soc. Amer., vol. 22, p. 352, footnote, I9II.

"Woodworth, J. B., Boulder Beds of the Caney Shales at Talihina, Oklahoma, Bull. Geol. Soc. Amer., vol. 23, p. 46r, 1912. 
than would be demanded for floating detached portions of mountain or plateau glaciers entering the sea in their zone of melting."

[The abundant evidence of Permian glaciation, etc., make it] "quite as reasonable to suppose that ice formed on the fresh waters of the Carboniferous." [Also, he says of a bed near the top of the Roxbury conglomerate:] "This presumably tillite bed is possibly of Permian age, but its association with the underlying conglomerates and similar thick, water-worn conglomerates of known Carboniferous (Allegheny) age in the Narragansett area points to the correctness of Shaler's theory of the glacial origin of the conglomerates as a whole."

The western instance is still an isolated one and may hardly yet be considered as definite proof of such low temperatures as are suggested by the authors cited.

Other evidence of a decided lowering of the temperature in PermoCarboniferous time is furnished by the change in life. David White, in the paper quoted (page 238), has noted the "rapid decrease, approaching extinction, of the colossal lycopods (Lepidodendriæ), and the rapid development of the group of gigantic tree ferns, such as Psaronius," with minor changes; all of which he regards as insufficient to indicate a great climatic change, but are clearly the beginning steps of what came later. Similarly slight but progressive changes are noted in Monongahela time, which, however, David White holds are still so slight that they indicate a moist and warm climate with absence of killing frosts or long-continued periods of aridity. In Dunkard time, however, the change was rapid and resulted in the formation of distinct climatic provinces. White does not believe that the eastern portion of the United States was extensively affected because of the continuation of the coal during the Permo-Carboniferous.

Aside from the change in the composition of the flora, the physiological adaptations have been used in an interpretation of climatic conditions. Xerophilous adaptations have been found in many plants of the late Paleozoic, and these have been interpreted as indicating a decided increase in aridity, but it is evident from the work of the botanists that xeromorphy in plants is attributable to more than one cause and is still incapable of exact interpretation. The occurrence of such structures in bog plants is well known, but its meaning is still in dispute. The matter has been reviewed by Clements, ${ }^{1}$ and without entering at length into the matter it may be stated that it has been suggested that the effect of decomposition in stagnant bogs and swamps is to produce both acidity and toxic products. It is assumed by some that the presence of one or both of these acts as a deterrent to root growth or functional activity and the xerophytic structure is a response to the inability of the plants to obtain an adequate supply of physiologically wholesome water. The literature of this matter may be followed from Clements's summary and from Dachnowski. ${ }^{2}$

${ }^{1}$ Clements, F. E., Plant Succession: An Analysis of the Development of Vegetation, Carnegie Inst. Wash. Pub. No. 242, p. 90, I916.

${ }^{2}$ Dachnowski, A., The Problem of Xeromorphy in the Vegetation of the Carboniferous Period, Amer. Jour. Sci., 4th series, vol. 32, p. 33, I9II. 
The interpretation of conditions from the presence of plants showing xeromorphic structures, in Pennsylvanian or Permo-Carboniferous time, is thus rendered very uncertain. Especially in the Permo-Carboniferous time, with its continuous approach to aridity, the interpretation is complicated by the evident close juxtaposition of a great variety of plant habitats. The need for caution in this particular is well illustrated in Spalding's discussion of the distribution of plants in an arid habitat. ${ }^{1}$ He shows clearly how purely aquatic plants assembled along water-courses may exist in close association with a purely desert vegetation, and it is evident that in such chance accumulations as might easily occur the fossilized remains might lead to very confusing and erroneous results if not correctly interpreted.

\section{In this connection, David White says:}

"Irregular temporary reductions or withdrawals of the water cover, possibly seasonal or perhaps less frequent, are, in the writer's judgment, causally related to the ordinary type of lamination of much of our coal, and the sheeting of the latter by fragments of 'mineral charcoal' ('mother of coal'). To their occurrence is probably due also the development of xerophytic and water-storage devices for the protection of so many of the coal plants of the Carboniferous swamps. Such periods of water reduction and evaporation appear generally to have been attended by concentration of the hydrocarbon solutes resulting from the putrefaction process in the form of paste, which now constitutes the jetlike 'binder' of the coal. Conversely, the alternate periods of rise of the water-level and the attendant dilution of the water cover favored to some extent not only the extraction, and, in cases of flushing, the removal of some of the putrefaction products from the upper part of the peat-forming débris, but also promoted the oxygenation and, consequently, the revival of decay wherever the asepticity was neutralized."

Turning to another phase of biologic evidence, Schuchert ${ }^{3}$ says:

"A climatic change naturally must affect the land life more quickly and profoundly than that of the marine waters, for the oceanic areas have stored in themselves a vast amount of warmth that is carried everywhere by the currents. The temperature of the ocean is more or less altered by the changes of climate, be they of latitude or of glaciation. The surface temperatures in the temperate and tropical regions, however, are the last to be affected, and only change when all of the oceanic deeps have been filled with the sinking cold waters brought there by the currents flowing from the glaciated area. We therefore find that the marine life of earlier Permic time was very much like that of the Coal Measures, and that it was not profoundly altered even in the temperate zones of Middle Permic time (Zechstein and Salt Range faunas). Our knowledge of Upper Permic marine life is as yet very limited and will probably always remain so because of the world-wide subtraction of the seas from the lands at that time. It was a period of continued arid climates, and the marginal shallow sea pans

'Spalding, V. M., Present Problems of Plant Ecology: Problems of Local Distribution in Arid Regions, Amer. Nat., vol. 43, I 909. Reprinted in Annual Report Secretary Smithsonian Institution for 1909 , p. 453.

${ }^{2}$ White, David, Origin of Coal, Bureau of Mines Bull. 38, p. 64, I9I3.

${ }^{3}$ Schuchert, Chas., Climates of Geologic Time, in Huntington, The Climatic Factor as Illustrated in Arid America, Carnegie Inst. Wash. Pub. No. 192, p. 279, I914. 
were, as a rule, depositing red formations with gypsum, and locally, as in northern Germany, alternations of salt with anhydrite or polyhalite in thicknesses up to 3.395 feet. In certain of these zones there were developed annual rings so regular in sequence as to lead to the inference that they were the depositions of warm summers and cold winters, enduring for at least 5,653 years (Görgey, I9I I)."

With reference to the insect life, Schuchert says:1

"The very large insects of the Coal Measures tell the same climatic story, for Handlirsch says that the cockroaches of that time were as long as a finger and the libellids as long as an arm. They were 'brutal robbers' and scavengers living in a tropical and subtropical climate, or at the very least in a mild climate devoid of frosts. We therefore conclude that after Middle Devonic time the climate of the world was as a rule uniformly warm and more or less humid and that it remained so to the close of Upper Carbonic time. ***"

[In Permian time] "the grand cosmopolitan swamp floras of the Upper Carbonic, consisting in the main of spore-bearing plants, such as the horsetails (equisetales), the running pines, and club-mosses (lycopodiales), and the ferns, among which were also many broad-leaved evergreens (cordaites) and seedbearing ferns (cycadofilices), were very largely exterminated in the southern hemisphere at the beginning of Permic time. In the northern hemisphere, however, the older flora maintained itself for a while longer, as best seen in North America, but finally the full effects of the cooled and glacial climates were felt everywhere. Then in later Permic time the old floras completely vanished, except the hardier pecopterids, cycads, and conifers of the northern hemisphere, and with these latter mingled the migrants from the hardy Gangamopteris flora originating in the glacial climate of the southern hemisphere. Some of the trees show distinct annual growth rings, and hence the presence of winters. It was these woody floras that gave rise to the cosmopolitan floras of early Mesozoic time.

"With the vanishing of the cosmopolitan coal floras also went nearly all of the Paleozoic insect world of large size and direct development, for the insects of late Permic time were small and prophetic of modern forms. Then, too, they all passed through a metamorphic stage indicating, according to Handlirsch, that the insects of earlier Permic time had learned how to hibernate through the winters in the newly originated larval conditions."

The change in land vertebrate life has been repeatedly demonstrated and the difficulties of interpretation caused by the discovery of generically identical forms as low as Middle Conemaugh and as high as the Clear Fork are removed by the position taken in this paper of a migration of the habitat from east to west, favorable conditions appearing at later and later intervals and at stratigraphically higher levels as the development of Permo-Carboniferous conditions is traced to the west.

The significance of "red beds" has been the subject of discussion for a long time, and it now seems to be fairly well accepted that such deposits, devoid of accompanying salt and gypsum beds, or with only a small percentage of such beds, is the result of a climate with moderate rainfall occur-

1 Schuchert, Chas., Climates of Geologic Time, in Huntington, The Climatic Factors as Illustrated in Arid America, Carnegie Inst. Wash. Pub. No. I92, p. 278. 
ring in rainy seasons alternating with dry seasons. Barrell says ${ }^{1}$ of the significance of the appearance of red sediments:

"Turning to the climatic significance of red, it would therefore appear both from theoretical considerations and geological observations that the chief condition for the formation of red shales and sandstones is merely the alternation of seasons of warmth and dryness with seasons of flood, by means of which hydration, but especially oxidation of the ferruginous material, in the flood-plain deposits is accomplished. This supplements the decomposition at the source and that which takes place in the long transportation and great wear to which the larger rivers subject the detritus rolled along their beds. The annual wetting, drying, and oxidation not only decompose the original iron minerals, but completely remove all traces of carbon. If this conclusion be correct, red shales or sandstones, as distinct from red mud and sand, may originate under intermittently rainy, subarid, or arid climates without any close relation to temperature and typically as fluvial and pluvial deposits upon the land, though to a limited extent as fluviatile sediments coming to rest upon the bottom of the shallow sea. The origin of such sediment is most favored by climates which are hot and alternately wet and dry as opposed to climates which are either constantly cool or constantly wet or constantly dry."

The question of the greatest climatic significance in the constitution of the red beds of Permo-Carboniferous time is whether the color is original or has been produced secondarily by a dehydration of hydrated oxides of iron by pressure or chemical change. That the color is a primary one due to deposition of the ferric oxide as such with the sandstones and shales is fairly certain. Observations by Case and by Baker have been reported upon this subject.

Case $^{2}$ says of the beds in Texas and Oklahoma:

"We may be certain that the red clays of Texas, with their ferric oxide, were deposited in the sea, or other bodies of water, in the condition in which they now occur, and are not due to subsequent dehydration or decarbonation, because (I) the color is uniform throughout; (2) because there is a solidity and density in the clays, and a lack of filled seams and veins, which would be impossible after such changes, which involve a decided increase in volume; and (3) because the red color transgresses into the limestones and sandstones with marine fossils."

Baker, ${ }^{3}$ writing of the same region, found that the following facts indicated a non-arid condition of 'Red Bed' origin:

“'I. 'Red Beds' are not being formed to-day in any desert region. On the contrary, they are being formed under conditions of warm, moist climates in the southern temperate and tropical regions, as maturely weathered residual soils. They are being formed, for example, in such regions as the southeast Texas Gulf Coastal Plain, the Great Valley of the Southern Appalachians, and as laterite in the subtropical and tropical regions.

1 Barrell, Joseph, Relations Between Climate and Terrestrial Deposits, Jour. Geol., vol. XVI, p. 292, 1908.

${ }^{2}$ Case, E. C., The Permo-Carboniferous Red Beds of North America and their Vertebrate Fauna, Carnegie Inst. Wash. Pub. No. 207, p. 43, I9I5.

${ }^{3}$ Baker, C. L., Origin of Red Beds, University of Texas Bull. 29, p. 3, I9I6. 
"2. The plant fossils' in the Wichita red beds of Texas and some other 'Red Beds' show no xerophytic adaptations. On the contrary 'red beds' are associated with coal deposits in various parts of the world.

"3. The amphibians and reptiles of Wichita time and the vertebrate fossils in some other 'red beds' were land animals which lived part of the time in water, part of the time on land. They did not live in a desert environment.

"But the presence of widespread deposits of salt and gypsum, of practically incontestable sedimentary origin, contemporaneous with the red clays, seemed to indicate conditions of aridity in at least later Permian time in Texas and elsewhere. Therefore, two working hypotheses were formulated to account for the conditions: (I) That the 'red bed' sediments were not originally red, but had in some way been changed to a red color subsequent to their deposition; (2) that the 'red beds' associated with the salt and gypsum were derived from old residual soils of moist warm climates, transported and deposited without change of color in the arid basins of the later Permian.

"At the time of the original investigation it seemed impossible to make a definite choice between these two hypotheses, and so the further investigation was held in abeyance. In more recent years, the examinations of samples from deep borings in the 'red beds' of Texas by Dr. J. A. Udden, ${ }^{2}$ has demonstrated the persistence of the red color in depth. So, although in some instances the red color may be secondary, in the red beds of Texas it is almost certainly primary, $i$. e., contemporaneous with the deposition of the sediments. Later, a re-examination in the light of late evidence of later Pennsylvanian and Permian geologic history of Texas has shown that the second hypotheses can be consistently advanced as the solution of the problem."

The lateral transition from light-colored sediments into red beds, typically along the Kansas-Oklahoma line, so often repeated, is also a point in evidence.

The very names used by well-drillers for certain horizons in Pennsylvania and West Virginia, as "deep red" shows that the color holds in the east and is original. Another convincing evidence of the original red color of the shales and sandstones has been noted by the author wherever he has seen red beds of Permo-Carboniferous age, from Prince Edward Island to Arizona. The red shales are frequently mottled by light blue or green dots, circular in section and evidently spherical in the undisturbed rocks. These are found in freshly fractured surfaces of fragments taken from the bottom of excavations so deep as to be beyond the reach of surface-waters. The only explanation for these spots is the presence of small bits of organic matter which reduced the ferric oxide after deposition. In other specimens from similar localities the light green or blue color appears in blotches and irregular patches, but all with sharply defined limits. In masses of hard red shale or sandstone nearer the surface the edges of cracks, both horizontal and vertical, have the same light green or blue color, due to the infiltration of surface-waters carrying organic matter.

${ }^{1}$ White, David, Jour. Geol., vol. xvII, pp. 320-34I.

${ }^{2}$ Udden, J. A., The Deep Boring at Spur, Bull. Bur. Ec. Geol. and Techn., Univ. of Texas, I914, No. 363. Potash in the Texas Permian, Ibid., No. I7, I9I5. 
In the Eastern Province the deposits of Pennsylvanian time below the middle Conemaugh are limestones, gray and black shales, and light-colored sandstones, evidently deposited in swamps or shallow basins subject to invasions by marine waters. The deposits were derived from low lands at great distances and laid down in either a submerged area or areas in which the water-table reached the surface, so that the iron which furnished a large part of the coloring matter remained in the ferrous condition.

The elevation of the eastern side of the continent was apparently beyond the limits, to the east, of the Appalachian trough, as is evidenced in the accumulation of conglomerates to the north and west of the Cobequid Highlands of Canada and in the Boston Basin. In the latter region the elevation was sufficient to produce at least local glaciation. To the south the elevation was less, but still sufficient to expose the igneous rocks of the pre-Cambrian core of Appalachia to the vicissitudes of a rigorous climate with wet and dry seasons. It is not necessary to assume that the climate was glacial or even semiglacial in the latitude of Pennsylvania and West Virginia; it may have been not unlike that of the present day, for red deposits are forming now in the Potomac River and the conditions in the southern Appalachians and upon the Piedmont Plateau are just such as would permit the formation of red sediments. Such an assumption is not inconsistent with the conception of local glaciation on higher areas, as, for instance, southeast of the Boston Basin.

The sudden change in the sediments and the uplift which they reveal, with the consequent climatic changes, are decidedly inconsistent with current conceptions of uniform conditions prevailing throughout Pennsylvanian time. The picture drawn by David White (see page 233) and the idea of a uniform climate prevailing over the earth from pole to pole ${ }^{1}$ is as correct as may now be given for the preserved portion of the Pennsylvanian series in the western part of the Eastern Province, but is applicable in the eastern part of the province to only those portions which lie below the red beds (middle Conemaugh).

As bearing upon this point it is of value to quote from a paper by Matthew, whose expressions are those of a trained vertebrate paleontologist. In remarking upon Chamberlin's theories of climatic changes, he says:

"Chamberlin's theories are to-day well known and are year by year gaining a wider acceptance. So far as they pertain to the present subject, they differ from the older prevailing concept of geological climatic conditions chiefly in that they involve an alternation of climates through the course of geologic time from extremes of warm, moist tropical and uniform, to extremes of cold, arid zonal climates. The former are the results of prolonged base-level erosion and the

${ }^{1}$ White, David, and F. H. Knowlton, Evidences of Paleobotany as to Geological Climate, Science, vol. 31, p. 760, 1910.

2 Matthew, W. D., Climate and Evolution, Annals New York Academy of Science, vol. XXIV, p. I73, 1915. 
overflow of large continental areas by shallow sea. The latter are the results of the readjustments needed to bring the continents once more into isostatic balance, involving the general lifting of the continents, especially of their borders, the expansion of the continental areas to their utmost limits, and the renewal of rapid erosion.

"These alternations of conditions are marked by alternations of the prevalent type of formation in the geological series. The uniform base-leveling corresponds to widespread deposits of limestones and in its waning stages with coal for mations. The periods of uplift are marked by thick barren formations, often red in color, by indications of arid conditions in salt and gypsum beds, and they finally culminate in great extension of glaciers from boreal and high mountain areas."

\section{CAUSE OF THE ClimatiC CHANGE.}

The evidence for a slowly maturing cycle of climatic change which culminated in excessive aridity in the late Permian or the Triassic has been presented. The possible causes, atmospheric content, solar heat affected by volcanic dust, and deformation, have been considered. The last was the precipitating cause, at least the one which can be rationally tested with the best hope of permanent results. The following discussion is limited to that cause alone, though there can be no doubt that the others very possibly were contributory.

The continuity of the great tectonic line which includes the Paleozoic Alps (Hercynian, Armorican-Variscan) of Europe and the Appalachian Mountains of North America is now beyond question and the progress of the movement from east to west along this line is equally well established. That there were movements even in the western part of the line at an early date is attested by the evidence of uplift even at its extreme western limit in mid-Pennsylvanian time. Blackwelder ${ }^{1}$ gives the following statement in regard to their movement:

"Arkansan (mid-Pennsylianian).-The folded structures underlying the mountains of Arkansas and Oklahoma were made, as nearly as can be inferred from current correlations, in the latter part of the Pennsylvanian period. Thus, in the central Arkansas coal field the deformation followed the laying down of the lower Pennsylvanian coal measures, ${ }^{2}$ but no younger strata exist there. In the Arbuckle Mountains of Oklahoma it occurred after the deposition of the Caney shale (early Pennsylvanian?) and before that of the Franks conglomerate (late Pennsylvanian). In the Wichita Mountains still farther west in the same State, the folds had been truncated before the deposition of the Oklahomian (early Permian) red beds. Thus it is the conclusion of $\mathrm{Taff}^{3}$ " that the Arbuckle uplift (= crumpling) began near the middle and culminated near the close of the Pennsylvanian time, previous to the deposition of the red beds. $* * *$

1 Blackwelder, Eliot, A Summary of the Orogenic Epochs in the Geologic History of North America, Jour. Geol., vol. xxIr, p. 64I, 1914.

${ }^{2}$ Collier, A. J., The Arkansas Coal Field, U. S. Geological Survey Bull. 326, p. 24, I907.

3 Taff, J. A., Geology of the Arbuckle and Wichita Mountains, U. S. Geological Survey, Professional Paper No. 31, p. 80, 1904. 
"The folding of the Ouachita beds has been referred by Dana and others to the Appalachian revolution. However, unless published correlations are seriously in error, we must conclude that the Ouachita folds had been formed and truncated before the deposition of the latest Pennsylvanian sediments, whereas the Appalachian folds were not begun until after the early Permian strata had been laid down. It is now generally agreed that the climax of that disturbance came near the close of the Permian period. If these correlations are correct, we must then recognize two separate orogenic epochs. There is apparently ground for correlating the Arkansan crumpling with that which produced the Armorican and Variscian systems of western Europe, which Haug assigns ${ }^{1}$ to the opening of the Stephanian (upper Pennsylvanian) epoch."

Disturbances coincident with Blackwelder's Arkansas orogenic movement are not recorded in any folding or disturbance of the rocks on the east side of North America later than the end of Mississippian in the southern Appalachians, but that there was an approximately coincident uplift of the land east of the Appalachian trough is recorded in sedimentary changes from Prince Edward Island to West Virginia. The descriptions of the Glasgow conglomerate, Roxbury tillite, and the red beds of West Virginia and Pennsylvania are given in the stratigraphic section.

The evidence for an uplift to the south and east of the Canadian and Massachusetts localities is included in the description of the rocks of those areas, and I. C. White's argument for the meaning of the sudden appearance of the red beds has been given (pages 65 et seq.).

${ }^{1}$ Haug, Emile, Traité de Geologie, vol. II, pt. I, p. 829, I9Io. 


\section{CHAPTER X.}

\section{AREAL GEOGRAPHY OF NORTH AMERICA IN THE LATE PALEOZOIC.}

As suggested in an earlier paper and in other portions of this work, the geography of North America was undergoing a progressive change during the latter part of the Paleozoic, and no one place or period can be considered as typical of the whole. Certain areas, however, are fixed for the whole time. The Paleozoic continent of Appalachia extended far to the east of its present exposure and for some undetermined distance beyond the present coast-line of the Atlantic. There can be no doubt that for a portion of the time some part of this continent was a high and rugged land. To the west of this land lay the sinking area containing the coal basins of the Pennsylvanian period, which was slowly filled in the latter half of that period, coincident with and dependent upon the elevation of Appalachia.

The same condition of depressed land with accumulation of swamp material existed to the northeast through eastern New England and the Maritime Provinces of Canada even to Prince Edward Island, but it is possible that this northeastern area continued to the south, somewhat to the east, and independent of the basin area in Pennsylvania and West Virginia. The southern extension of the Boston and Rhode Island Basins was very probably directly to the south, and such sediments as may now be preserved are beneath the surface of the ocean.

South of West Virginia and Kentucky the surface of the eastern part of the United States was above the plane of deposition and no record is preserved.

The great area including western Pennsylvania and West Virginia stretched away to the west as far as the eastern border of the uplift in central Missouri. It was broken by the elevated land around the Cincinnati uplift, but the series of beds may, in part, be traced through the portion of Kentucky to the south. The southern peninsula of Michigan was at this time probably in the last stages of the formation of the upper coal beds of that State.

The elevated area in Missouri was subjected to partial invasion by local seas from Illinois and from Kansas in late Pennsylvanian time, but soon became dry land, and during all of the Permo-Carboniferous was out of water and undergoing erosion. It is very probable that through all of the late Paleozoic there was a land area north of Missouri which reached up to the southern edge of the Canadian shield. 
West of the Missouri land there was sea during the first part of the late Paleozoic which endured well into the Permo-Carboniferous and only slowly and reluctantly yielded to the prevailing movements of elevation and the accompanying climatic change which culminated in the desiccation of the Triassic.

Beyond this western sea was the great barrier where the Rocky Mountains now stand. There can be no doubt that by the last half of the Pennsylvanian this barrier was prominent and effective, and one is led to suspect from the amount of material derived from it that it was far larger and broader than has yet been suggested. This barrier was not complete between the Plains and Basin Provinces, for marine and terrestrial deposits of the late Paleozoic may be traced more or less completely around the northern and the southern edges. Though there are short breaks in the connection between the beds on the two sides of the barrier in the south and the character of the sediments changes, it seems very probable that the terrestrial conditions of the eastern side shaded off into marine conditions toward the west, in trans-Pecos Texas. The northern limit of the barrier is equally uncertain. It may have extended north to where the uplift merged into the highlands of the Canadian shield, but the short distance between the sediments of the two provinces in Wyoming and north of the Big Horn Mountains and the probability of continuity in some places indicates that the barrier was broken in several places. The late Pennsylvanian marine deposits of the Basin Province merged to the north into the similar deposits of the great sea of the same age which covered Alaska and western Canada; the Permo-Carboniferous deposits of inclosed and stagnant seas, in the same age, lie upon the southern edge of the land formed by the uplift which drained this sea toward the close of Pennsylvanian time. In greater detail the geography of the continent was approximately as follows:

In middle Pennsylvanian time the continent of Appalachia extended far to the north and south on the eastern side of North America; its surface, as indicated by the derived sediments, was in general marked by a subdued topography; west of this upland lay a broad area of very slowly sinking land, in which the accumulation of fine sediments kept pace with the subsidence, maintaining a nearly constant but low level of the surface. The rate of subsidence must have been very slow, for the character of the sediments accumulated upon it indicate that the land-surface from which they were derived was so low and gentle that erosion must have been very gradual. For the most part the surface of the sinking area was marked by the presence of great fresh-water swamps, alternating with low elevations and stretches of open water due to local invasions by marine or brackish water.

The subsiding area west of Appalachia was divided into two distinct parts, approximately the same in position as the Northeastern and the Southern Subprovinces of the Eastern Province, defined previously. The northeastern part, including eastern New England, the Maritime Provinces 
of Canada, and Prince Edward Island, was made up of isolated and semiisolated troughs of varying size, outlined by the pre-Pennsylvanian surface. The whole outline of this area and the general trend of the individual troughs indicate a contour parallel to the older elevations of western New England and of this portion of Canada and to the (probable) western edge of Appalachia. The distinct character of this area is indicated not only by the shape of the troughs and the different character of the deposits, dependent largely upon the small size and isolation of the troughs, but upon the difficulty in correlating the deposits with those of the larger basin to the southwest. The continuation of the northeastern area to the south beyond the coast of Rhode Island is strongly suggested and leads to the impression that a depression existed in the surface of Appalachia which continued south for an unknown distance, entirely east of the present exposed edge of that old land. If this be true, Pennsylvanian deposits must lie buried beneath the coastal waters of the Atlantic and the deposits of the Atlantic Coastal Plain. The presence of such a depression, even if confined only to the northern part of Appalachia, would have an important bearing upon the explanation of the different character of the sediments in the Northeastern and the Southern Subprovinces.

The southern basin was far larger than the northeastern. It extended from the western edge of Appalachia far into Ohio and Kentucky and at its largest reached into Indiana and Illinois. As has been repeatedly shown, the basin was contracting from originally very wide limits through all Pennsylvanian time, until in the Conemaugh and Monongahela it was restricted to western Pennsylvania and West Virginia and eastern Ohio and Kentucky. The portion west of the Cincinnati anticline, originally connected with the eastern part, was in late Pennsylvanian time receiving deposits as a completely or partially isolated area. In middle Conemaugh time came the first effects of the uplift of the eastern side of North America; the eastern part of the basin continued sinking under the accumulating load of sediments, but the western part was gradually raised into the zone of erosion and purely terrestrial deposition.

The elevation of eastern North America, the initiation of Permo-Carboniferous conditions, produced very different effects in the two subprovinces.

The first deposits of the northeastern basin are coarse conglomeratesthe lower conglomerates of Prince Edward Island, the New Glasgow conglomerate, the Roxbury conglomerate, and the Dighton conglomerate. A part of these, the Squantum tillite member of the Roxbury conglomerate, is of glacial origin, and glacial conditions lingered for some time, as is shown by the series of advances and retreats of the ice demonstrated by Mansfield. ${ }^{1}$

${ }^{1}$ The author is as fully aware of the uncertainty of the stratigraphic position of the deposits in the Boston Basin as his readers will be, but believes that the similarity of conditions there to those of deposits of determined stratigraphic position to the north and south is a bit of confirmatory evidence of their Permo-Carboniferous age worthy of consideration. 
All of these heavy deposits came from the east (Prince Edward Island) or southeast (New Glasgow, Boston, and Narragansett Basins), and were evidently derived from a notably high and rugged land in these directions. It is probable that they were derived from a distinct range involving the Cobequid Hills, some pre-Pennsylvanian elevations in New Brunswick, and a now-submerged portion which occupied a part of the broad continental shelf which extends as far south as Long Island Sound. Its further extension is entirely problematical.

The southern basin was evidently much farther removed from any source of coarse sediments. If the range of uplands postulated above was continued any farther south than is indicated by the present contour of the continental shelf, it was separated from the western side of the Appalachia by a continuation of the depression of the northeastern basin in which was trapped the coarse material derived from it, or its trend carried it so far east that only the finer material was transported to the southern basin. It is, perhaps, more probable that the range merged into the generally lower surface of the southern portion of Appalachia and that coarse sediments were not originated in any quantity.

The general elevation which raised the northern or eastern portion of Appalachia sufficiently to bring it within the possibility of local glaciation and vigorous erosion affected the southern or western portion only sufficiently to initiate a milder erosion under a variable climate resulting in the formation of finer red sediments.

The progress of the elevation was slow. In the northeastern basin the coarse sediments soon gave place to fine red sands and shales, indicating the lowering of the rugged heights; and in the southern basin the finer red sediments only partially replaced the darker shales, light-colored sandstones, and thin limestones, which shows that the area continued to subside as fast as it was filled. The western part of the southern basin, receiving a far smaller load of deposits, was raised more rapidly until western Kentucky, Indiana, and Illinois were above the plane of deposition; deep valleys were being cut and purely terrestrial beds accumulating while the eastern half was still sinking beneath its increasing burden. The lack of adjacent lands high enough to furnish much sediment under the influence of a variable climate accounts for the lack of red sediments except in small and local patches. North of Ohio and Indiana, the surface of the lower peninsula of Michigan was still covered by coal swamps after sedimentation had ceased to the south. Northern Illinois and Wisconsin were a part of the low-lying land area extending south from the Canadian shield. Similar conditions prevailed to the west, where the highland of Missouri continued to the north through Iowa to the old land of Canada; here Permo-Carboniferous conditions left little trace, for, as has been shown by the author, the red shales and sandstones of Webster County, Iowa, are in all probability a residual soil of Missourian age. 
The topographic changes resulting from the broad uplift initiated on the eastern side of the continent were accompanied by climatic changes fully as important. Though the continued subsidence of the eastern half of the southern basin may in part have maintained the humid and singularly equable climate, as a local phase, the incursion of the red sediments from the east show that on the higher land a cooler, variable climate, with alternate periods of drought and humidity, had set in. The vegetation of the upper Pennsylvanian which is recorded in this basin was very possibly a persistent phase holding over in a locally favorable environment, while the general environment had changed to the new "Permo-Carboniferous conditions." Farther west, beyond the limit of red sediments transported from Appalachia, the land gradually rose and the changed climate is only recorded in a few and scattered evidences of erosional activity, terrestrial accumulation, and evidences of decreased humidity. Due to the direction of the tilting, sedimentation continued for a longer time in the West under the conditions prevailing in Pennsylvanian time, but in Indiana and Illinois ceased before the "Permo-Carboniferous conditions" had migrated that far west. The result was that the line of changed sediments marking the advance of the climatic change rises toward the west across the stratigraphic column and if continuous would lie above the plane of deposition in Illinois and Indiana. (See fig. 7, p. I92.)

South of the elevation in Missouri, sedimentation terminated within the limits of the Pennsylvanian. No evidence of conditions during PermoCarboniferous time has been discovered in that region.

West of the Missouri land and surrounding the southwestern extension of Ozarkia, "Permo-Carboniferous conditions" were coincident with PermoCarboniferous time. At the close of the Missourian period, which corresponds to the upper half of the Pennsylvanian in the Eastern Province, the sea still covered a good part of the Plains Province, and was bordered on the east by the terrestrial deposits and coal swamps which lay on the western slope of the Missouri land. The movements of the sea over this land and its final retreat have been detailed on pages 82-84. To the south the sea bordered on the northern, western, and eastern sides of the southwestern extension of Ozarkia, a good portion of which was finally buried by marine and terrestrial deposits, leaving exposed only the portion now occupied by the Wichita Mountains and the Arbuckle Hills. The eastern side of this portion of Ozarkia was in imperfect connection with the highland of Missouri and northern Arkansas. Coal swamps and narrow stretches of sea covered the lower land at alternate intervals.

As Permo-Carboniferous time progressed, the sea contracted, and gradually retreated toward central or north central Kansas, where limestone and marine shales continued to be deposited long after terrestrial conditions were established all around the last remnant of the sea. The Plains Province 
consists essentially of the area occupied by this sea and the terrestrial deposits formed upon the land laid bare by its contraction.

The uplift of the continent, apparently, did not raise the Missouri land sufficiently to produce any large accumulation of red sediments; if any were formed they have been completely removed by erosion on the centraleastern side of the province, or such small remnants as may persist are hidden beneath the glacial or younger deposits of soil. On the southern and western sides the uplift of Ozarkia and the Rocky Mountain barrier was sufficient to furnish enormous quantities of material under the changed climatic conditions. So great, indeed, is the amount of Permo-Carboniferous "redbed" material that the source as now revealed is entirely inadequate, and some authors, notably Schuchert, are inclined to believe that a considerable portion of the material in the southern part of the Plains Province must have been derived from the elevated area in southern Texas and northern Mexico, the old positive element, Columbia. In this southern portion of the Plains Province red sediments accumulated until they spread far and wide, principally to the south, west, and north of the land, and finally partially buried their source.

In a similar way the Rocky Mountain barrier between the Plains and Basin Provinces furnished red sediments which were spread out on the eastern face of the barrier and for an unknown distance out upon the Plains Province, where they are now hidden by overlying younger deposits. In the south these sediments can be traced west from the barrier until they approach very closely to those derived from Ozarkia, but the actual meeting of the two, if it occurs, is hidden under the southern part of the Staked Plains. Farther to the north, in the latitude of Tucumcari, New Mexico, the exposed red beds are Triassic in age; these may be traced to the great sandstone plateau east of Las Vegas and picked up again on the edge of the mountains. If any Permo-Carboniferous material occurs in this region, its exposure is confined to a narrow strip on the eastern slopes of the foot-hills which continues through northern New Mexico into southern Colorado. What the extent of the buried Permo-Carboniferous sediments may be we can not tell, for the similarity between the late Paleozoic and Triassic red beds is so great that they can not be distinguished in well records.

From Canyon City, Colorado, north to the Black Hills, the red sediments continue unbroken and unchanged, indicating a similarity of conditions amounting to identity in climate, height of the barrier, and all inorganic factors. The total absence of any trace of land vertebrates is inexplicable; by all evidence of the sediments the environmental conditions were strikingly similar to those existing in Texas and Oklahoma. So many men have gone over these beds in the hope of finding vertebrate fossils that some fragments of bone, at least, would have turned up had the animals existed in any abundance. Some, as yet not realized, factor of distribution of the sedi- 
ments has prevented the occurrence of fossils or some obscure factor prevented the occurrence of animals in this large area.

In this connection it is pertinent to recall that the size and nature of the barrier between the Plains and Basin Provinces is still little understood. The widespread marine sediments of late Pennsylvanian time and their great thickness strongly suggest a suppression of the Rocky Mountain axis at that time and it is the opinion of some writers that the whole region was entirely submerged. On the other hand, the amount of Permo-Carboniferous sediment is so great that it can only have come from a very large area and the nature of the material implies considerable height and vigorous erosion. The change in the sedimentary record reveals an important uplift forming an elevation of a height and geographical extent for which we have no other evidence.

There is some good reason to believe that the barrier between the two provinces failed in the region of the Black Hills and Bighorn Mountains. The Permo-Carboniferous red beds of the Black Hills unquestionably belong to the Plains Province and the equivalent red beds of the western side of the Bighorn may be traced with little question into the phosphate-bearing beds of the Basin Province. If the barrier continued to the north it must have passed between the two elevations, but it is very probable that the elevations were far less prominent in the late Paleozoic than now and that they were nearly, if not quite, covered by the sediments of the time. If the red sediments are continuous between the two, the provinces were united at the northern end and the source of much of the material was from the permanent land to the north and east.

At their southern ends the two provinces are separated by the great mass of late Pennsylvanian limestone, now thrown up into the series of low mountain ranges which run through central New Mexico. Whatever may have been the condition in Permo-Carboniferous time, there was clearly an effective barrier to the migration of vertebrate land animals, for the reptiles and amphibians found near Soccoro and Abiquiu are distinctly different from those found in the Plains Province. There can be no doubt that in late Paleozoic time the western part of trans-Pecos Texas and the adjacent portions of Mexico and New Mexico were covered by a sea which extended into Arizona. This sea left the great Guadalupian series of limestones, the upper part of which is Permo-Carboniferous, possibly true Permian, and the sea may have extended to the north, constituting a temporary but effective barrier to land life. It is true that the upper limestone of the Guadalupian series shades off into red deposits toward the north, implying land in that direction. In the absence of any definite evidence of a high mountain barrier, the presence of a temporary arm of the sea would be the most satisfactory explanation of the separation of the two faunas; it would constitute an efficient continuation of the land barrier farther north. 
On the west side of the Rocky Mountain barrier the deposits of the Basin Province resemble those of the Plains Province and the environment of life was the same, as far north as southwestern Colorado and southern Utah; beyond, to the north, conditions were radically different through the most of the Basin Province. Only in central Wyoming do the PermoCarboniferous deposits of the Basin Province shade again into red beds typical of the Plains Province.

The upper Pennsylvanian sea occupied the Basin Province, depositing heavy limestones and, toward the end, receiving great quantities of sand in its northern half, the present Weber quartzite and its equivalents. The limestone may be traced with a fair degree of certainty into Canada and the quartzite may be followed as far, from its first appearance in central Utah, until the two apparently merge into the Cache Creek formation.

In the southern part of the Basin Province the elevation permitted red beds of Permo-Carboniferous age to accumulate directly upon the limestone, but farther north the elevation of the barrier to the east must have been somewhat earlier, and the sands of the Weber and its equivalents were deposited under Pennsylvanian climatic conditions. The Permo-Carboniferous deposits of the northern half of the Basin Province were laid down in stagnant seas and under climatic conditions not greatly different from those of the late Pennsylvanian.

The difference in the sediments on the two sides of the barrier reveal important climatic differences. The source of the Weber sands and the limestones and fetid shales of the Park City formation must have been the same as that of the red beds of the eastern side of the barrier, and the structure and size of grain reveal no great difference in the shape or slope of the two sides. The main erosion of the western side took place in late Pennsylvanian under Pennsylvanian climatic conditions and of the eastern side in Permo-Carboniferous time under Permo-Carboniferous climatic conditions, but from the absence of red beds on the western side of the barrier, except where it was probably broken down at the northern end, and from the constant indications of the large size of the barrier, the question naturally presents itself whether the barrier may not have interrupted prevailing winds, or otherwise caused a difference in humidity and temperature upon the two sides.

The sum of accumulating evidence shows that marine conditions prevailed in late Pennsylvanian from Alaska south along the Pacific coast to northern California; in British Columbia the sea extended as far east as the west side of the Canadian Rockies and south to the international boundary, where it was continuous with the sea which occupied the Basin

FIG. 8.-Map showing the distribution of late Paleozoic and Permo-Carboniferous deposits in North America. The portion of Canada and the United States to the west of the heavy broken line was the site of deposition in Gschelian time and elevation in late Paleozoic. 


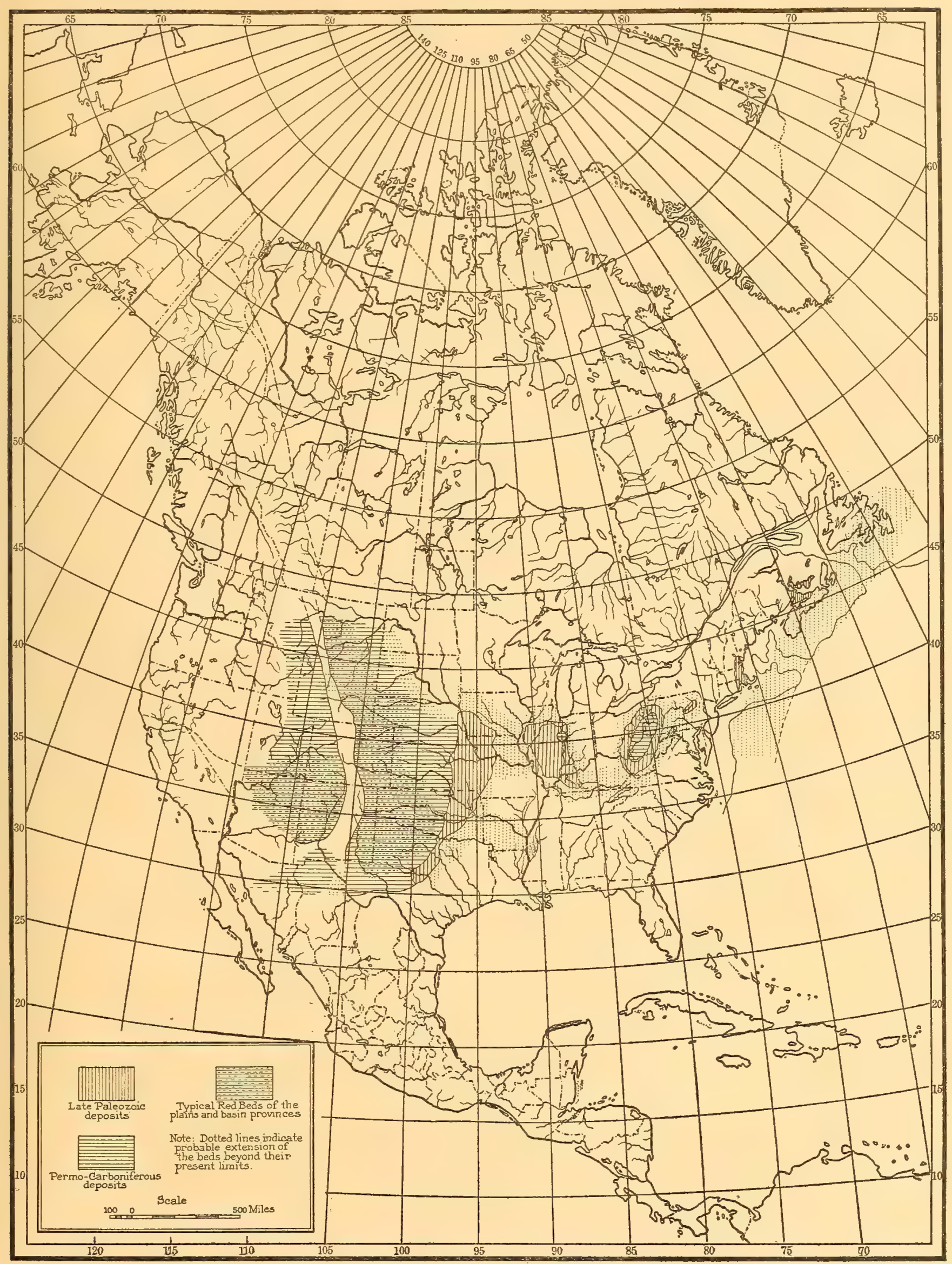


Province. There is little doubt that the deposits along the Pacific coast were made in a sea which was in more or less open connection with the one which lay over British Columbia, but all of the sedimentary deposits of the eastern sea have been so disturbed by earth movements and so seriously metamorphosed that the correlation can only be made in a very broad way. One thing is becoming increasingly evident-that the limestones and associated clastic sediments of Alaska and western Canada were deposited in a sea of late Pennsylvanian time, equivalent to the Gschelian.

In late Pennsylvanian an uplift, first apparent in northern Alaska, developed and spread to the south. This movement was accompanied by much diastrophism and vulcanism which, with later phenomena of like kind, have sadly obscured the record. The effect of the whole movement was to raise the surface above the plane of marine deposition during Permo-Carboniferous time and no traces of terrestrial deposition or erosion during that time have as yet been detected.

This uplift was of the first importance and had a two-fold effect upon the geography and the environment of life during Permo-Carboniferous time: (I) The movement of the uplift was progressive from north to south, at right angles to the progressive movement of uplift of the continent throughout late Paleozoic. It is very probable that the progressive uplift from north to south, exerting most of its effect farther west, penned in a part of the sea which occupied the northern half of the Basin Province in Pennsylvanian time and converted it into the relict seas of Permo-Carboniferous time in which were deposited the phosphate shales and limestones of the Park City formation. (2) The uplift converted the northwestern part of the United States and the western part of Canada into an upland which joined the northern end of the Rocky Mountain barrier between the two provinces and prevented the accumulation of Permo-Carboniferous sediments north of the international boundary. The land area thus formed furnished a reasonable route of migration for the Gigantopteris flora from its home in Asia to the location in Texas where it has been found.

The upper limit of Permo-Carboniferous time or "Permo-Carboniferous conditions" is as yet undeterminable with any exactness. In the regions where Triassic red beds overlie those of Permo-Carboniferous age, there is no evidence of earth-movements of any magnitude, but there is constant evidence of an increasing aridity which became so vigorous as to be a prominent, if not the dominant, factor in the change of vertebrate life, so pronounced at the juncture of the two periods. 


\section{CHAPTER XI.}

\section{DEVELOPMENT AND FATE OF VERTEBRATE LIFE IN THE PERMO-CARBONIFEROUS IN RELATION TO ITS ENVIRONMENT.}

The study of the development of vertebrate life in North America during late Paleozoic time emphasizes the changes from a long period of slow evolution in a singularly monotonous environment through a period of rapid expansion in a diversified environment to final extinction. As has been repeatedly intimated in the course of this work, the chief directing influence in the sudden expansion was a decided climatic change, accompanied by physiographic changes, induced by an alteration in the level of the surface of the continent.

The basis for any study of the vertebrate fauna in relation to the environment must be a study of the morphology of the forms involved. Previous publications of the Carnegie Institution of Washington by the author and others have summarized this as far as our present information permits. The material in the preceding pages summarizes our knowledge of the environment in a similar way.

In attempting an analysis of the response of the vertebrates of the late Paleozoic to the changing environment it is necessary to begin the study with at least the middle of Pennsylvanian time, in order to understand the conditions which fixed upon the animals the homoplastic characters which were developed in the Permo-Carboniferous radiation. There can be no question that the radiation of the fauna began with the development and spread of "Permo-Carboniferous conditions" in the middle Conemaugh time, not at the beginning of Dunkard time as has been commonly assumed. It is therefore of the utmost importance to keep clearly in mind the great change in the inorganic environment which came with the development of Permo-Carboniferous conditions.

Fortunately for the simplification of the work, the conditions during early Pennsylvanian time were singularly uniform over large areas. ${ }^{1}$ David White has repeatedly emphasized the equability of the humid climate. The work of David White, Stevenson, and others has emphasized the topographic uniformity of the slowly sinking coal basins, in which the filling maintained a nearly constant level. Under such conditions the ultimate food-supply, vegetation, would be fixed in kind though abundant in quan-

${ }^{1}$ See analysis of an environment on p. 40. 
tity. Such an environment would permit an enormous increase in numbers, but the increase in kinds would reach a definite limit, whether large or small. A monotonous environment does not imply a small number of genera and species in a fauna or flora, but it does imply a distinct limit to the number. The struggle for existence can result in the persistence of new forms only so far as the new forms can find an isolation or favorable environment; beyond that point new forms can not survive and a period of stagnation in development will ensue, the stagnation being more or less complete as the monotony of the environment is more or less pronounced and long-continued. This condition will be in the nature of an end-result upon a fauna or flora and the effect does not necessarily extend to the suppression of variability in the individual organisms. In the struggle for existence, induced by increasing numbers and closer adjustment of the inter-relations between distinct species, the amount of variability might remain the same or even be accentuated. In the author's opinion the tendency to continue the development along definite lines, call it by what name we will, would be seriously affected by the failure of new forms to develop to maturity. The lack of mature new forms would prevent the survival of new structures demonstrating the tendency of evolution, beyond a certain point, but, at the same time, the constancy of the environmental conditions would tend to fix ever more firmly the tendency and increase the number of variants in that direction. Viewed as a whole, then, the end-result would be, on a large scale, somewhat as discussed in the author's paper on the Linton fauna. The animals in their environment of limited possibilities of morphological expansions would soon fill all of the available spaces and new forms would cease to reach maturity, this being largely due to the early extinction of the variants. The continued and increasing pressure to produce new forms because of the fixation of the tendencies would impose upon the fauna as a whole a state of stress to which it would need only the relief afforded by the possibilities of migration into a new environment or of a change in the environment to find expression in a rapid development of new types. This opinion is opposed by my colleague, Dr. A. F. Shull, who suggests that an inherent tendency to evolution along definite lines would find relief in the mere production of offspring and that the fauna would not experience an increase in any tendency to develop along definite lines or any increase in the number of variants. This suggestion has great force and it may well be that it is the true situation. The author is well aware of the limitations of the evidence at the disposal of the paleobiologist, but the evidence is so conclusive and repeated of long periods of stagnation in evolution followed by rapid development that he can not rid himself of the impression that faunas in periods of stagnation go through a period of preparation, in some form, for their subsequent radiation. 
Environmental monotony would result in the persistence of older and simpler types because the variants, possibly being constantly produced, would not have a chance to develop.

Another result of the long association of the unchanging or only slowly changing members of the fauna would be a very close adjustment of the interrelationships of the various elements of the fauna, and of the fauna with the flora and the inorganic environment. In a region of large possibilities of varied habitat such persistence, amounting to static conditions, might result in the production of highly specialized types showing excessive morphological characters, but in a region of limited possibilities of habitat the morphological expression of close adjustment would be less obvious. Close adaptation of the interrelationships is in itself an evidence of the long association of comparatively fixed groups, and when this finds expression in the skeletal structure it can easily be read in the fossils, but if it is expressed in physiological characters or in habits not revealed in the structure, as peculiarities of feeding, etc., or in other things which may seem to the observer minute and unimportant but are in reality vital, the record is not decipherable.

Again, as has been shown by Beecher, certain morphological peculiarities are produced only in the senility of a group and are characteristic of it; the upper Paleozoic air-breathing vertebrates were still in the best stage of their development. Though amphibians appeared in the Devonian and footprints record their occurrence through the Mississippian and early Pennsylvanian, their progress seems to have been very slow, a condition which is analogous to that of the mammals in the Mesozoic.

We have as yet no knowledge of the place of origin or the direction of migration of the Permo-Carboniferous fauna, and speculation upon changes induced by migration into new regions must be based on very meager evidence. It is altogether possible that in their slow development the primitive amphibia migrated only into extensions of their original environment and so experienced little change in their surroundings and received no stimulus to evolution. The almost purely aquatic character of the primitive amphibians and the intolerance to salt water, so characteristic of the living, and presumably of the fossil, forms would tend to restrict their movements most decidedly. Only when the as yet undetermined influence which compelled a change appeared or gathered sufficient force to cause a vigorous development would they burst through the physiological barriers and begin their radiation.

The upper Pennsylvanian air-breathing vertebrate fauna was young, very numerous in individuals, possibly in kinds, but restricted in its further development by the monotony of the environment. It was, however, accumulating force towards a great radiation to be expressed as soon as the limitations were removed, even in a partial degree. 
The middle of Conemaugh time saw the beginning of the end of the fixed environment of the amphibia and the first reptiles. The change began on the eastern side of the continent and the record as shown by the deposits has long been recognized. Girty says: ${ }^{1}$

"The Upper Carboniferous, rather in contrast with the Lower, was a period of emergence of shores and of shallowed waters, and it presents the variety that appertains to such conditions. In considering the stratigraphic relations of eht Pennsylvanian and Permian one can not fail to be struck by the local character of the phenomena, and the vast amount of detail, from which it is difficult to disengage facts of broader significance."

"Lithologically the beds of the Upper Carboniferous" and Permian present the greatest variety, and about the only truth of broad applicability has long been known. I mean that in eastern North America the sediments of the Upper Carboniferous are chiefly shales, sandstones, and conglomerates, with some thin limestones, while in the West the limestones have a much larger development, and coals, which toward the east play so important a part, if not in thickness at least economically and significantly in the Carboniferous sediments, are there practically absent. From this it has been justly inferred that the character of the eastern Carboniferous indicates shore and estuarine conditions of deposition, while that of the western indicates marine conditions of deposition."

The variety of sediments emphasized by Girty is, however, rather a repetition of a relatively few kinds of beds than an evidence of varied habitat.

The same change is recognized by David White, ${ }^{3}$ who notes that the beginning of Stephanian time dates from the Hercynian uplift in Europe, but that the abrupt differences of level and vegetation do not appear in America:

"In view, however, of the paleobotanical evidence indicative of a point near the Allegheny-Conemaugh boundary, I, personally, am inclined to regard the formation of the Mahoning sandstone (conglomeratic), the changed sedimentation of the Conemaugh formation, the probable upwarp of the southern Appalachian region which later resulted in the exclusion of the sea from the northern area also, and the consequent climatic changes, as due to the same great orogenic influence. Accordingly I would provisionally place the greater part, if not all, of the Conemaugh together with the Monongahela in the Stephanian.

"The final exclusion of the sea from the Appalachian trough appears to have occurred soon after the deposition of the Ames limestone, near the middle of the Conemaugh, since, according to reports, only fresh or possibly brackish water mollusca occur in the higher terranes. It is probable that the Monongahela was never deposited in the southern Appalachian region, from portions of which the Conemaugh may also have been absent, the red oxidized sediments of the latter being in part derived, I believe, from the eroded unconsolidated older Pennsylvanian to the southeastward."

\footnotetext{
${ }^{1}$ Girty, G. H., Outlines of Geological History, p. 124, I9ro.

${ }^{2}$ Idem, p. 126.

${ }^{3}$ White, David, Outlines of Geologic History, p. I48, I9ro.
} 
The same change is noted by I. C. White, ${ }^{1}$ who, however, emphasizes the change in life which followed the change in environment:

"Viewed from the standpoint of change in physical conditions the proper place for such a dividing-plane between the Conemaugh and Allegheny beds would be the first general appearance of red rocks, near the horizon of the Bakerstown coal, about roo feet under the Ames or crinoidal limestone horizon. That a great physical change took place soon after the deposition of the Mahoning sandstone rocks, the present basal members of the Conemaugh series, must be conceded, since no red beds whatever are found from the base of the Pottsville up to the top of the Allegheny, and none worth considering until after the epoch of the Upper Mahoning sandstone.

"The sudden appearance or disappearance of red sediments after their absence from a great thickness of strata is always accompanied by a great change in life forms, and the present one is no exception. In fact, the invasion of red sediments succeeding the Mahoning sandstone epoch of the Conemaugh may well be considered as the 'beginning of the end' of the true Coal Measures, both from a lithological as well, as a biological standpoint, and hence it is possible that the best classification, aside from the conveniences of the geologist, would leave the Mahoning sandstone in the Coal Measures, and place the rest of the Conemaugh, as well as the Monongahela series above, in the Permo-Carboniferous. This reference is also confirmed by the character of the fauna and flora, both of which contain many forms that characterize the Permo-Carboniferous beds of Kansas and the west as may be seen in the lists published on a subsequent page under the detailed description of the principal Conemaugh strata."

In previous pages emphasis has been placed upon the physical change which began on the eastern side of the continent and spread to the west. The land was gradually elevated east of the coal basins and a cooler and less humid climate accompanied the elevation. It has been pointed out by David White, Stevenson, and others that the eastern half of the Southern Subprovince continued to sink for some time after middle Conemaugh time, as it received the added load derived from the rising land to the east, but the change of the sediment and, above all, the new elements in the fauna and flora, show that the climatic change was having its effect. Beyond the limits of the basin in all directions the lack of accumulating sediments permitted the elevation to have full effect.

The fauna, long restrained from any expression of its evolutionary tendencies, full fed, and in the vigor of its youth, responded at once to the change, and new forms appeared so suddenly as to be unheralded in the preserved remains. This is of course more apparent than real, but there was unquestionably a rapid evolution amounting to vigorous radiation, expressed especially in those features which were adapted to life upon a drier land or in aquatic areas of far wider possibilities of varied habitat than in the enormous and monotonous swamps. Either of these conditions, rapidity of evolution or life away from favorable conditions for the preservation of the remains, would lessen the probability of the preservation of the connecting forms.

There can be no question, however, that the response to the changed environment was rapid and in favorable localities very complete. The

I. White, I. C., West Virginia Geological Survey, vol. II, p. 226, I 903. 
variants upon the strongly impressed homoplastic characters were now able to survive and in the multitude of new forms far-reaching readjustments were necessary to the changed interrelationships. The environment, long monotonous, became increasingly diversified, until the elevation and the climatic change had produced their full effect, and new avenues of migration were constantly opening westward. The number of individuals was far less relative to the available space, and the cloture of the environment was removed. In the readjustment many of the animals found an isolation which permitted rapid development of morphological peculiarities.

The author must here repeat to some extent his conception of isolation in the sense here used. The environment of any organism is the sum of all its contacts with the external world, organic and inorganic. If the organism, by virtue of its structure, habits, acquired immunity, or other means attains a position in its enviroment where it is relieved from prejudicial contacts either in part or in toto, it just so far attains an environmental isolation and is free to develop individual peculiarities. This is decidedly different from geographical isolation, though the latter may result in the same benefits to the organism. Environmental isolation may be attained even in a very thickly inhabited region. A typical case is that of the modern skunk; another is the Permo-Carboniferous reptile Dimetrodon, which, by increase in size, agility, and raptorial powers, so far dominated the fauna in which it lived that it was isolated from many disadvantageous contacts and developed probably incipiently useful structures to marked excess.

Such a condition of environmental isolation, attained by only a portion of the fauna, accompanied by close adaptations in the interrelationships of the members of the fauna, could only be attained after a really long period of association; in the early stages of such an association, changes of farreaching effect would occur. The individuals would be free in a large measure from peculiarities, except inherited ones developed under the earlier, more stable conditions. Such peculiarities would be very apt to be disadvantageous, and the animals possessing them would disappear, and the less-specialized forms would gradually assume peculiarities as adjustment took place under the new conditions. As intimated above, the extinction of certain forms and much of the readjustment would take place in a time of rapid evolution and the record would be very faulty from the lack of preserved material. It has frequently been shown that the changes from uniform conditions of the land to elevated and disturbed conditions have always been relatively rapid, while the return to low lands and a positive movement of the strand-line have been relatively slow. Thus the airbreathing life was uniformly subjected to relatively rapid changes effecting a violent disturbance of the established relations, followed by a long period of extremely gradual return to monotonous conditions, producing frequently a static environment, during which readjustment took place. 
As the change which affected the environment of the upper Pennsylvanian fauna was an elevation and exposure of the land with little deposition the record of the life change, in preserved fossils, is very imperfect, the continued sinking of the land in the eastern part of the Southern Subprovince maintained the old conditions and archaic types of life in the area best explored and has given a false impression of the general state of affairs. The record there preserved is of a relict fauna, while the record of the advancing development in progress on the higher lands is not preserved or has not yet been discovered. Matthew, in his essay upon climate and evolution, has given his ideas of the effect of such a change as occurred in late Pennsylvanian time: ${ }^{1}$

"The periods of continental emergence were periods of arid and markedly zonal climate, and the faunæ must adapt themselves to these conditions. Such conditions, while favoring the spread and wide distribution of races, would be unfavorable to abundance of life and the ease with which animals could obtain a living. The animals subjected to them must maintain themselves against the inclemency of nature, the scarcity of food, the variations of temperature, as well as against the competition of rivals and the attacks of enemies. In the moist tropical climatic phase, animals would find food abundant and temperature relatively constant; but the larger percentage of carbonic acid and probably smaller percentage of oxygen in the atmosphere during those phases would tend to sluggishness.

"We should expect, therefore, to find in the land life adapted to the arid climatic phase a greater activity and higher development of life, special adaptations to resist violent changes in temperature and specializations fitting them to the open grassy plains and desert life. In the moist tropical phase of land life, we should expect to find adaptations to abundant food, to relatively sluggish life, and to the great expanse of swamp and forest vegetation that should characterize such a phase of climate."

While these remarks are largely applicable to the mammals with which Dr. Matthew is chiefly concerned in his essay, similar effects would doubtless be produced in lower forms of life.

The place of origin of the Permo-Carboniferous fauna is unknown. As shown previously there are reasons for considering that the North American radiation of the Permo-Carboniferous fauna started in the eastern part of the continent, but this is far from proven. Until more detailed work shall establish the true relations of North America to the other continents of late Paleozoic time the question may not be settled. The question of the origin of the fauna and its relations to the somewhat similar fauna of South Africa is discussed in a preliminary way elsewhere (Carnegie Inst. Wash. Pub. No. 207, p. II7). It is the opinion of the author that the North American fauna was unique in its adaptations and radiation and that the presence of such highly specialized forms as Edaphosaurus in Saxony and Bohemia was due to later migrations. This opinion may very

${ }^{1}$ Matthew, W. D., Climate and Evolution, Annals N. Y. Acad. Sci., vol. xxıv, p. I77, 1915. 
possibly be shown to be erroneous. The presence of such highly specialized forms, so little changed as to be only specifically separable, at such widely separated localities leads to a consideration of the effect of wide migration upon a fauna. Matthew, in his paper on climate and evolution, discusses this effect. ${ }^{1}$

"Whatever agencies may be assigned as the cause of evolution of a race, it should be at first most progressive at its point of original dispersal, and it will continue this progress at that point in response to whatever stimulus originally caused it and spread out in successive waves of migration, each wave a stage higher than the previous one. At any one time, therefore, the most advanced stages should be nearest the center of dispersal, the most conservative stages farthest from it. It is not in Australia that we should look for the ancestry of man, but in Asia.

"In the same way, in considering the evidence from extinct species as to the center of dispersal of a race, it has frequently been assumed that the region where the most primitive member of a race has been found should be regarded as the source of the race, although in some instances more advanced species of the same race were living at the same time in other regions. The discovery of very primitive sirenians in Egypt, while at the same time much more advanced sirenians were living in Europe, has been regarded as evidence that Africa was the center of dispersal of this order. It is to my mind good evidence that it was not. It is very common to see references to the African facies of the Miocene or Pliocene mammals of Europe; but it is much more correct to say that the modern African fauna is of Tertiary aspect and is in large part the late Tertiary fauna of the northern world, driven southward by climatic change and the competition of higher types.

"The chief arguments advanced in support of the method here criticized appear to be that the modification of a race is due to the changes in its environment and that the primitive species are altered more and more as they spread out or migrate into a new environment; but, assuming that a species is the product of its environment, the conclusions drawn would only hold true if the environment remained constant. This is assuredly not the case, and if it were there would be no cause left for the species to change its range. In fact, it is the environment itself, biotic as well as physical, that migrates, and the primitive species are those which have followed it, while those which remained have had to adapt themselves to a new environment and become altered thereby. Probably it is never the case that the environment of the marginal species is an absolute replica of the older environment of the race. In many cases it must be profoundly modified by its invasion of new regions, and there are many features in the evolution of a race which appear to be only partly, if at all, dependent on environmental change. But to assume that the present habitat of the most generalized members of a group, or the region where it is now most abundant, is the center from which its migrations took place in former times appears to me wholly illogical and, if applied to the higher animals, as it has been to fishes and invertebrates, it would lead to results absolutely at variance with the known facts of the geologic record."

${ }^{1}$ Matthew, W. D., Climate and Evolution, Annals N. Y. Acad. Sci., vol. Xxiv, p. 180, 1915. 
From the above it is evident that Matthew considers that peripheral species of an expanding fauna are the most primitive and that species near the point of origin show the greatest modification. This might be true under certain conditions, but only if the migrant species followed a migrating environment which advanced as an expanding belt without change and if the original location underwent progressive change. It is obvious that this is not always the case; in the Permo-Carboniferous radiation the change of environment starting from the eastern side of the continent spread out, not as an expanding belt, with other and new conditions arising at the original source, but rather as an expanding blanket from a source where conditions remained constant. In this case, certainly, the migrant forms would follow the edges of the expanding environment, but the point of origin would offer no stimulus for further-change and the fauna would be similar in all parts, except that at the place of origin where the fauna had lived longest in close association there would be closer adaptations in the interrelations of the organic environment, and except as the factors of evolution which are independent of the environment made themselves felt. In such highly specialized forms as.Edaphosaurus, as widely separated as Bohemia and New Mexico, it is certain that one place, at least, is far removed from the place of origin. There is, of course, the possibility, less in the reptiles perhaps than in the mammals, of recurrent migration or of the active migration of groups during really short intervals of time, within an environment very similar over large areas; this might cause certain forms to become very widely spread and to confuse the interpretation of the fossil record.

With the spread of Permo-Carboniferous conditions, the fauna of the time extended its range over a large part of the United States at least, if not over a large part of the continent. Whether the fauna occupied all parts of its extreme range at any one time is uncertain, but it is certain that in late Paleozoic, true Permo-Carboniferous time, it extended from Pennsylvania to New Mexico, and it is very probable that it existed in regions where no remains have been discovered. The large proportion of exposed land in the eastern and southern parts of the United States permitted little preservation of the remains of the animals, if any were present. Beyond New Mexico we have no record and in the northwest marine conditions prevailed during Gschelian time and gave place to elevated land, with the accompaniment of volcanic disturbances and earth-movements which probably prohibited the presence of the peculiar vertebrate life, though it permitted the passage of the fern Gigantopteris.

Permo-Carboniferous vertebrate land life came completely to an end in North America and, so far as we can tell, suddenly. Inadequate history makes it impossible to draw conclusions which approach to finality, but the chances for the discovery of far-reaching evidence are seemingly so small that it is well to summarize what can be said from that now available. 
It is certain from the interpretation of structure that a great preponderance of the fauna was palustrine in habit. This is certainly true of the Amphibia and equally true of most of the Reptilia. Certain of the reptiles were adapted to other conditions, as the very swift, perhaps arboreal, Areoscelis, and Edaphosaurus, whose structure and the method of occurrence leads to the belief that it was an upland animal. The fauna as a whole migrated with the extension of its peculiar habitat, following the retreat of the swamps and marine littoral probably to the westward, and came to an end with the habitat. The upland members of the fauna, many of which have undoubtedly left no traces of their existence, lingered upon the higher lands and may have moved about freely, even penetrating back to the eastern side of the continent.

It is at least suggestive that Edaphosaurus, an upland form, is found farthest from the locus of the greatest abundance of the genus, but an equally significant fact, if we could understand it, is the presence in the same locality (Bohemia) of Cricotus, or a closely related form, the most aquatic of the Amphibia.

The only consideration that offers a possibility of reconciling these apparently contradictory bits of evidence is that Edaphosaurus was capable of wide migration because of its land habits, and Cricotus was equally capable because of its power as a swimmer. If Cricotus had the intolerance of salt water so characteristic of the Amphibia, and there is no evidence to the contrary, there must have been a peculiarly favorable geographical arrangement that permitted these two forms of such different structure and habits to reach the same locality after such a long journey. If Cricotus was tolerant of salt water, it is strange that no remains have been found associated with the widely distributed Mesosaurus.

The great majority of the fauna seem, so far as we can tell, to have been greatly favored by their environment, but to have been closely restricted by it and quite unable to adjust themselves to changing conditions.

The close of Permo-Carboniferous conditions and the beginning of Triassic conditions was accomplished within the limits of the "red beds," and certainly within the limits of any known occurrence of air-breathing vertebrates, by a steady increase in the aridity of the climate, with a consequent decrease in the area of aqueous habitats and an increase in the salinity of such as remained, which were largely desiccating pools.

To anyone who has studied the red beds of late Paleozoic and early Mesozoic time the similarity in the structure of the two is beyond question, but the evidence of gradually increasing aridity is equally obvious. The Permo-Carboniferous beds do not contain any large amount of salt or gypsum or other evidence of extreme aridity in the lower middle portionsthe equivalents of the Wichita and Clear Fork formations-where the fauna occurs, but such evidence increases in the upper portion and in the Triassic 
beds it reaches a maximum. As is well known, there is no great structural break at the top of the Paleozoic series in these regions; in only one place, near Ouray, Colorado, is there known even a considerable unconformity at the base of the Triassic.

It must be remembered that the deposits of the red beds of late Paleozoic and early Mesozoic are not in any degree continuous. They consist of lenses and small irregular bodies of shale, sandstone, and clay, with small layers of impure limestone, following each other in no persistent sequence. This is so pronounced that a section made at one place is not to be depended upon even within the distance of half a mile. A consideration of the many sections taken in the regions concerned will reveal this condition.

Despite the similarity of the beds revealing similar conditions of deposition, the beds carrying Permo-Carboniferous vertebrates are uniformly followed by a barren interval and then by the appearance of typical Triassic forms. Other than the obvious climatic change, there is no suggestion of a cause for the extinction of the fauna, but the climatic change is itself a sufficient explanation. The members of the fauna were closely adapted to every phase of their environment, and, in taking advantage of abundant possibilities, had developed to a high degree of specialization. They had passed the zenith of their development and the group as a whole was in a stage of developmental senility where overdevelopment of certain morphological characters is the common condition. Flexibility in evolution was so far lost that with the advent of a new environment the fauna disappeared. This is quite what would be expected. The only question is whether the fauna was totally extinguished upon the continent and replaced by a new fauna developed elsewhere, or whether some of the less-specialized forms survived to give rise to the Mesozoic types. This question can not be answered at present, but so far as we know there were no survivals in North America. What was going on in the portions of the continent from which we have no record we do not know; it is possible that some of the forms migrated to the continents of the Old World and there perpetuated the fauna in the Triassic. One thing is very definite at present: no form has been found which bridges the gap between the North American fauna and that of the Triassic. The two occur in the same localities, but are separated by a barren space in the geological column, and when the new forms appear they are already well-defined Mesozoic types. So far as we can now tell, the Permo-Carboniferous land vertebrates became extinct upon the North American continent and the Mesozoic forms appeared by migration from an unknown source. Perhaps connecting-links may be found in North America, but at present there is no suggestion that they exist or of where to search for them. 





SSONIAN INSTITUTION LIBRARIES

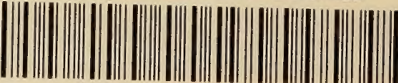

